Universidad deValladolid

PROGRAMA DE DOCTORADO EN CONSERVACIÓN Y USO SOSTENIBLE DE SISTEMAS FORESTALES

TESIS DOCTORAL:

\title{
REVISIÓN Y EVALUACIÓN TÉCNICO - ECONÓMICA DE LOS SISTEMAS DE MICRO- RIEGO USADOS EN REPOBLACIÓN FORESTAL
}

\author{
Presentada por Jorge Del Río San José para optar \\ al grado de \\ Doctor por la Universidad de Valladolid
}

Dirigida por:

Dr. D. Andrés Martínez de Azagra Paredes

Dr. D. José A. Reque Kilchenmann 



\section{A Valle \\ A mi familia}

“_Buenos días! — dijo el principito.

—Buenos días! — respondió el comerciante.

Era un comerciante de píldoras perfeccionadas que quitan la sed. Se toma una por semana y ya no se sienten ganas de beber.

— ¿Por qué vendes eso? — preguntó el principito.

-Porque con esto se economiza mucho tiempo. Según el cálculo hecho por los expertos, se ahorran cincuenta y tres minutos por semana.

- ¿Y qué se hace con esos cincuenta y tres minutos?

—Lo que cada uno quiere... "

"Si yo dispusiera de cincuenta y tres minutos — pensó el principito— caminaría suavemente hacia una fuente..."

Antoine de Saint-Exupery (1943)

El principito 



\section{Agradecimientos}

Esta tesis presenta similitudes con un brinzal que nació siendo una pequeña idea hasta llegar a su arraigo final. Quiero mostrar mi reconocimiento y agradecimiento a todos los que lo han hecho posible

A mis directores de tesis, Dr. D. Andrés Martínez de Azagra Paredes y Dr. D. José A. Reque Kilchenmann, mi más sincero agradecimiento por compartir vuestra sabiduría con un joven investigador, por el dialogo permanente, siempre enriquecedor, por la generosidad y humor en vuestra enseñanza, y por la motivación, tenacidad, paciencia, actitud y espíritu crítico que han hecho posible este trabajo, aun atravesando condiciones adversas. He sido muy afortunado. Gracias por vuestra amistad y ejemplo, siempre estaré en deuda con vosotros.

A mis compañeros de trabajo por sus ánimos permanentes para concluir esta tesis. Especialmente a Jesús Hernández, Javier Gordo, Luis Finat, Alfonso González y Carmen García-Jiménez (D.E.P.) por compartir su experiencia en la aplicación de los cuidados culturales en las repoblaciones forestales.

A Mariano Monsalve, por su crónica sobre la repoblación con biberón en el Cerro de San Cristóbal. A Francisco Morán, por sus explicaciones sobre los conteos de las marras. A Pieter Hoff, por transmitirme la opinión de los inventores y fabricantes de los sistemas de micro-riego en repoblaciones y a Pablo Martínez Zurimendi, por mostrarme el mundo del umbral de daños en las plagas y por su presentación en Lugo.

A mi gran familia, a Valle y especialmente a mis padres porque gracias a su sacrificio y cariño incondicional, me dieron la posibilidad de estudiar y fomentaron mi interés por la ciencia y la tecnología. 



\section{Índice}

Índice i

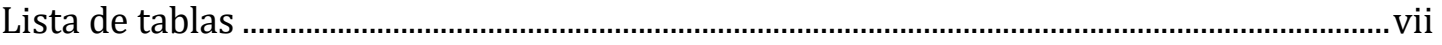

Lista de figuras................................................................................................................................ ix

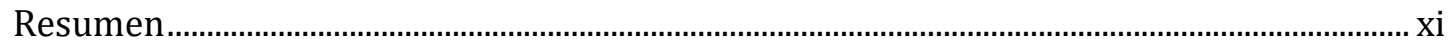

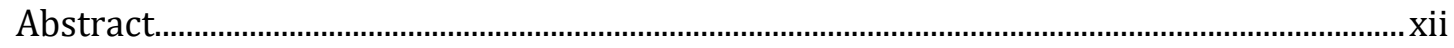

Presentación general de la tesis doctoral....................................................................................

Capítulo 1. ¿Riego de brinzales? Revisión crítica .................................................................. 1

1. La difusión de las innovaciones agrarias .................................................................................... 3

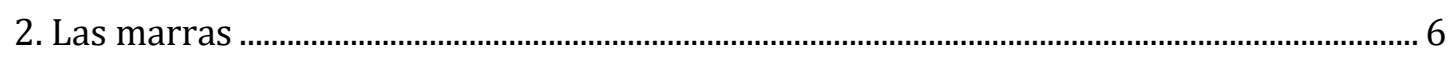

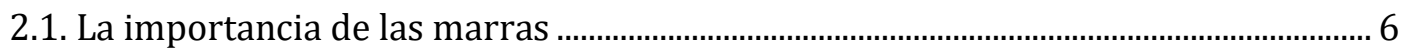

2.2. Las múltiples e insuficientes cuantificaciones de las marras por estrés hídrico..... 8

3. La gestión de las marras por estrés hídrico ..........................................................................10

3.1. La preparación del terreno ………………………....................................................10

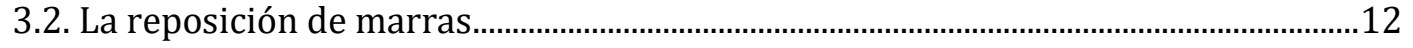

3.3. Los cuidados culturales ................................................................................................13

4. El riego de brinzales .............................................................................................................17

4.1. Tipos de riego forestal ........................................................................................................17

4.2. Los riegos de establecimiento de brinzales ……..........................................................18

4.2.1. El sobrecoste del riego ……………………….........................................19

4.2.2. La economía circular ..................................................................................19

5. Sistemas de decisión aplicados a la selección de cuidados culturales en las plantaciones

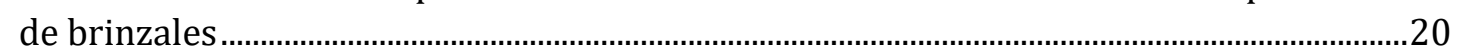

5.1. La herencia de los sistemas de decisión de la gestión forestal ....................................20

5.2. La crisis actual en la elección de cuidados culturales basados en los sistemas de

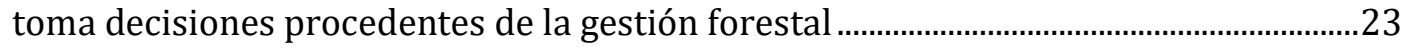

5.3. La necesidad de un marco propio para la selección de cuidados culturales............24

6. Las incertidumbres en la toma de decisiones sobre cuidados culturales .........................27

6.1. La necesidad de información: bases de datos sobre marras .........................................27

6.2. La incertidumbre global sobre la utilización de la tecnología del riego en el establecimiento de brinzales en los proyectos de repoblación ............................................28

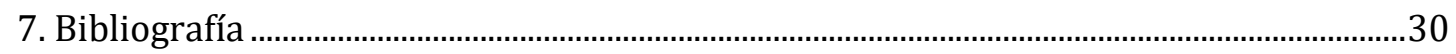

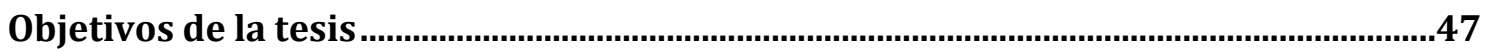


Capítulo 2. Revisión de la tecnología del riego para el establecimiento de brinzales 49

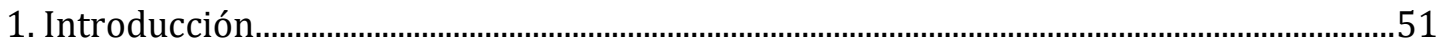

2. Definición y características generales......................................................................................52

3. Descripción de los distintos sistemas................................................................................5

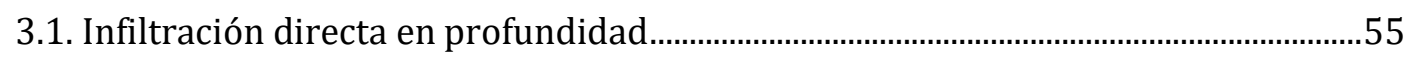

3.1.1. Micro-riego por medio de tubos verticales.................................................55

3.1.2. Riego mediante drenes horizontales........................................................58

3.2. Riego a través de paredes porosas (rezumadores) …………………….......................58

3.2.1. Riego mediante tarros de barro enterrados................................................59

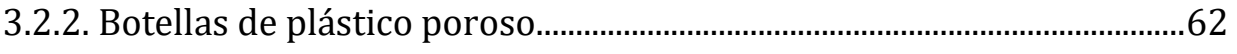

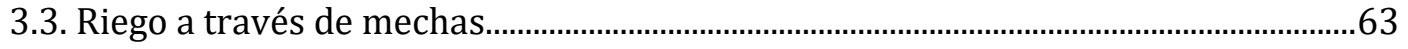

3.4. Riego con destiladores solares .........................................................................................68

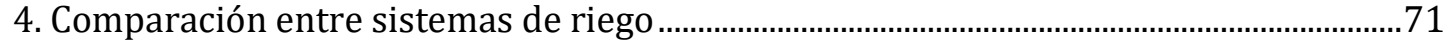

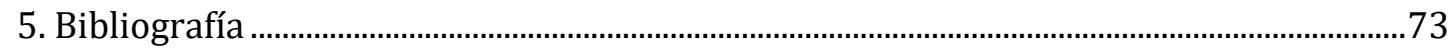

Capítulo 3. Ámbitos de estudio científico sobre la tecnología del riego para el

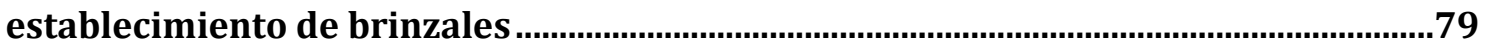

1. Temas centrales en el estudio científico del riego de brinzales .........................................81

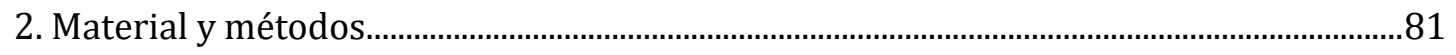

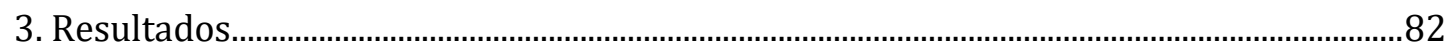

3.1. La evolución temporal del número de publicaciones .....................................................82

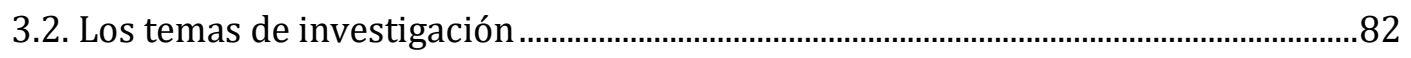

4. Discusión: Necesidades de investigación................................................................................87

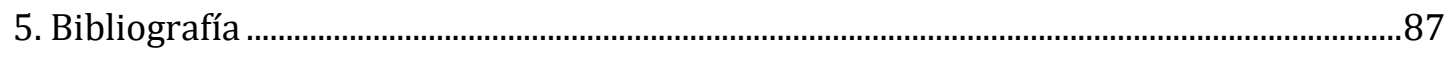

Capítulo 4. Eficiencia técnica de los sistemas de riego de brinzales...............................89

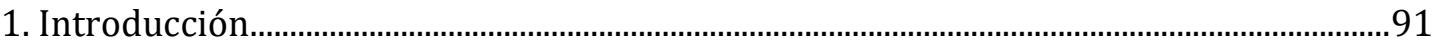

2. Material y métodos...........................................................................................................92

2.1. El método de análisis envolvente de datos .....................................................................92

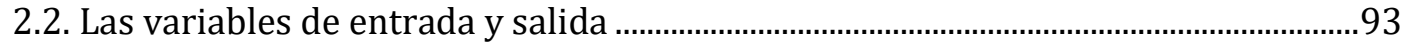

2.3. Los niveles de decisión (DMU) ......................................................................................93

2.4. Orientación y cálculo del modelo ………………….........................................................95

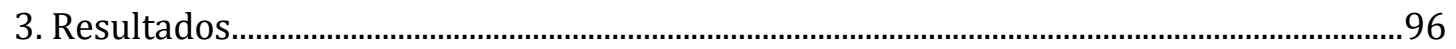

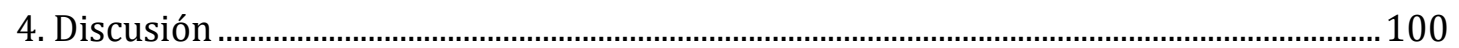

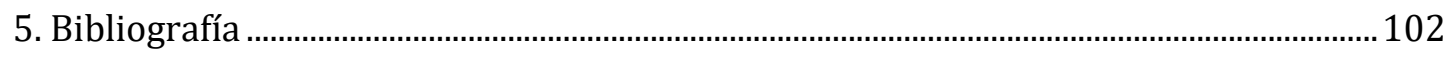


Capítulo 5. To replant or to irrigate: A silvicultural decision model for afforestation projects . 107

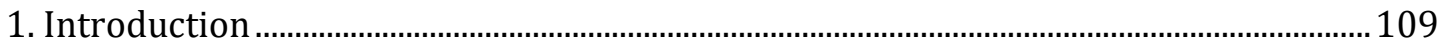

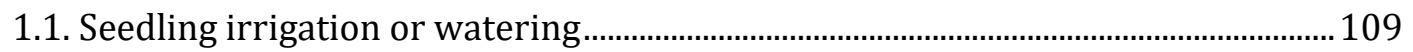

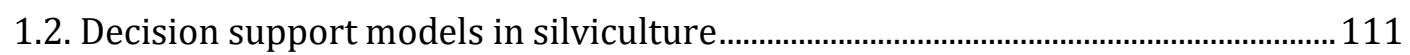

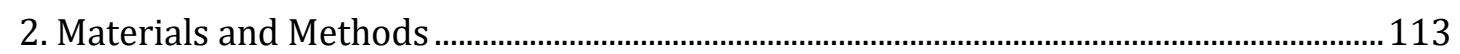

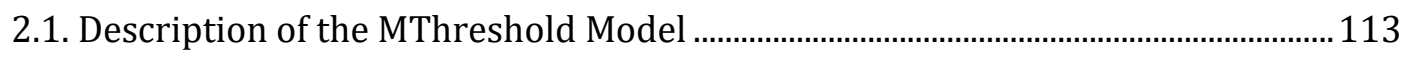

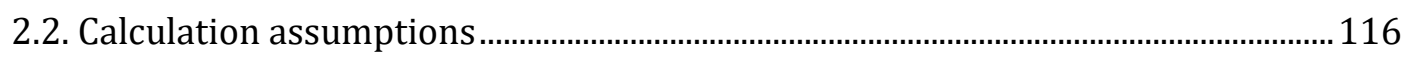

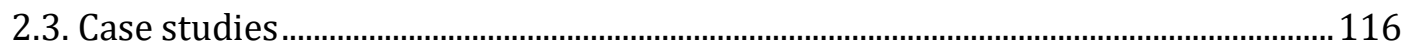

2.4. Sensitivity analysis procedure …………………………......................................... 120

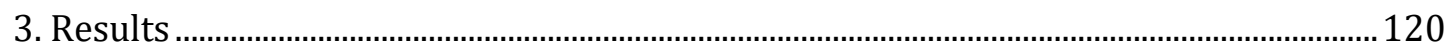

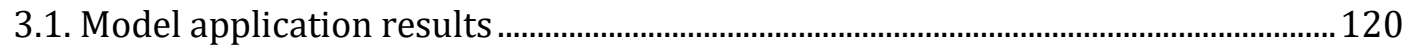

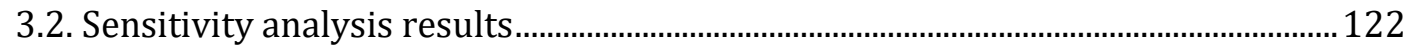

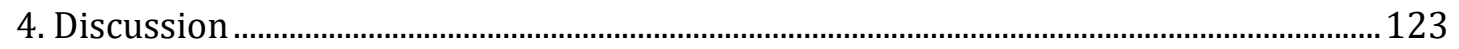

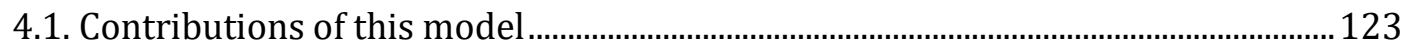

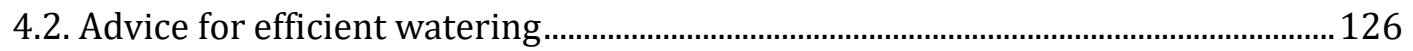

Appendix A. Description of the cost and benefit terms ...........................................................128

A.1. Individualized cost equations ……………….............................................................. 128

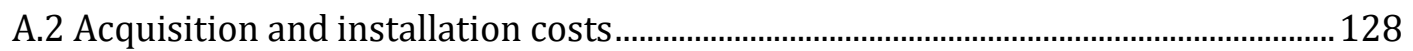

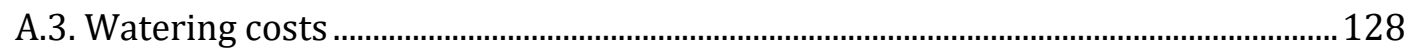

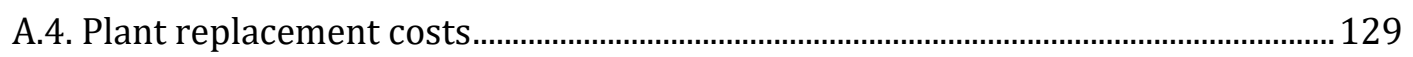

A.5. Labour costs of the replacement of failed seedlings ................................................... 129

A.6. Difference between the expected benefits for each option........................................ 130

A.7 Early benefits ................................................................................................................ 130

A.8. Lost profit due to the replacement of failures ............................................................ 131

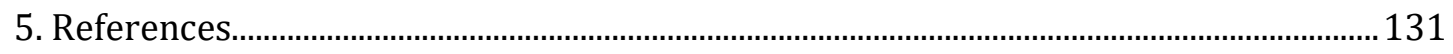

Adenda. Elementos de apoyo para la utilización del sistema de ayuda a la toma de

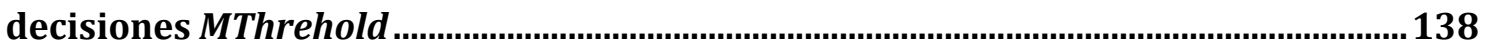

1. Consideraciones sobre algunas variables de diseño de las repoblaciones forestales 138

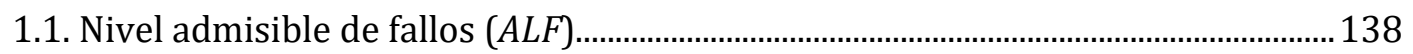

1.2. Número de años en que la producción se acelera debido a la irrigación $(\varepsilon)$......... 140

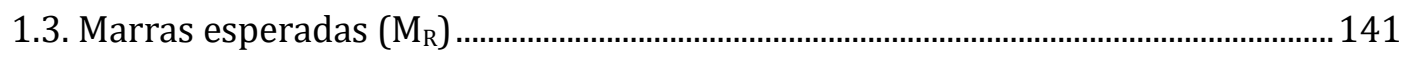

2. Umbrales de decisión en cada grupo de aptitud al riego................................................... 143

2.1. Convergencia de la simulación de Montecarlo .............................................................. 144 
2.2. Umbrales de decisión por grupo de aptitud según la simulación de Montecarlo 145

3. Hipótesis sobre las causas de las marras a través de los valores del modelo ...... 148

4. Bibliografía 148

Capítulo 6. Herramienta informática para la integración económica del riego de brinzales en el diseño de plantaciones....................................................................153

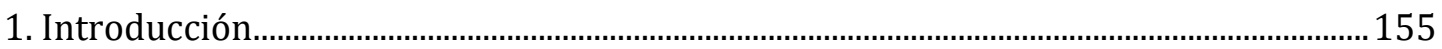

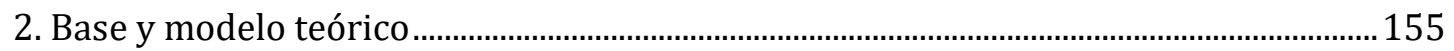

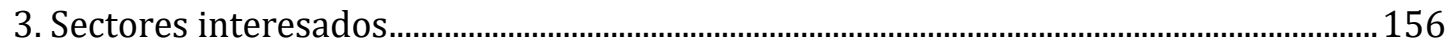

4. Componentes del programa ……...................................................................................... 157

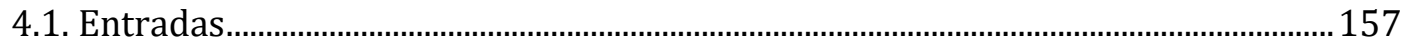

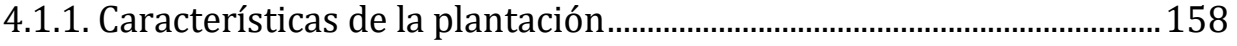

4.1.2. Características del riego ............................................................................. 158

4.1.3. Características financieras........................................................................... 159

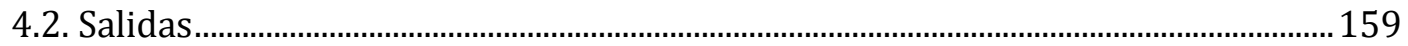

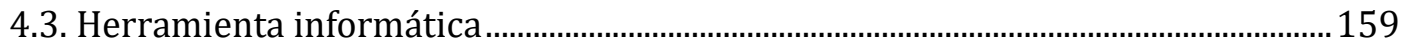

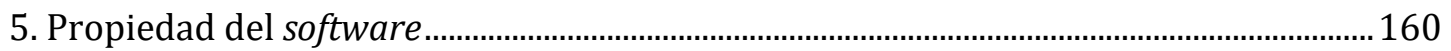

6. Ejemplo de aplicación del programa ………………..........................................................160

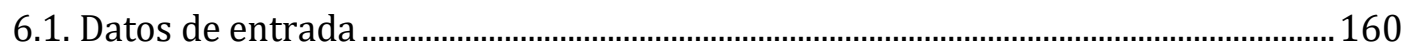

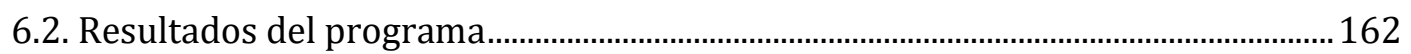

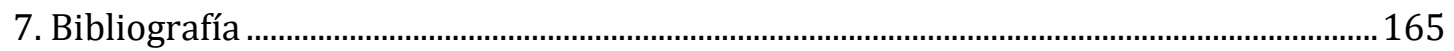

Capítulo 7. Estimación del tamaño potencial del mercado de sistemas de riego de brinzales en plantaciones forestales en tierras áridas..................................................167

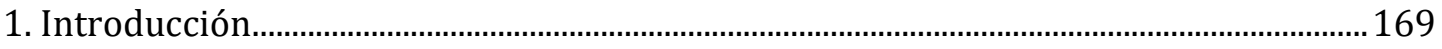

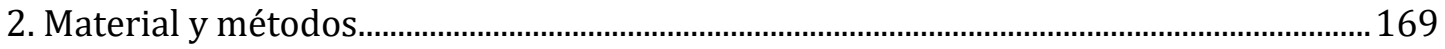

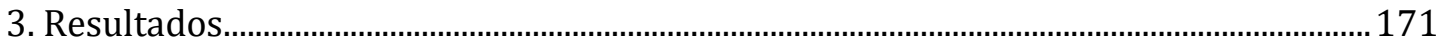

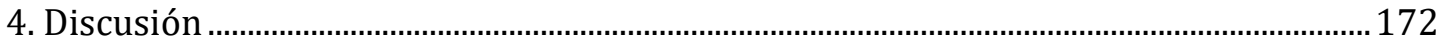

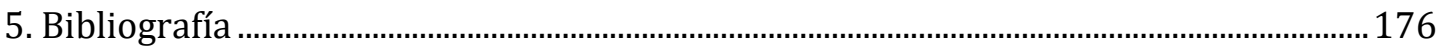

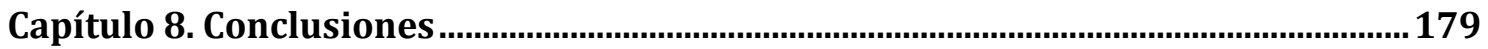

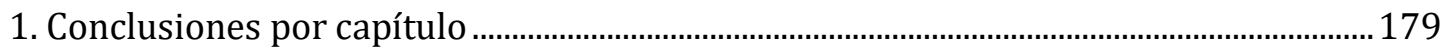

Capítulo 1: El riego de brinzales en la acción repobladora .......................................................179

Capítulo 2: Sistemas de micro-riego de brinzales................................................................... 179

Capítulo 3: Revisión sistemática de publicaciones .....................................................................180

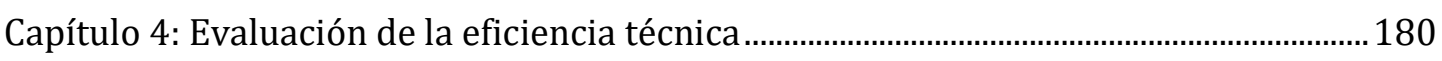

Capítulo 5: Modelo MThreshold .............................................................................................. 181 
Capítulo 6: Software del modelo 182

Capítulo 7: Tamaño de mercado de los sistemas de micro-riego forestal. 182

2. Conclusiones principales... 185

ANEJO 1. Relación de publicaciones realizadas como consecuencia de la tesis ........187 


\section{Lista de tablas}

Capítulo 1. ¿Riego de brinzales? Revisión crítica 1

Tabla 1. Fuentes de incertidumbre del riego de brinzales. 6

Tabla 2. Cuidado cultural aplicable en función de la causa de la mortandad de brinzales 16

Tabla 3. Principales finalidades de los DSS de selección de cuidados culturales según destinatario.

Objetivos de la tesis. .47

Capítulo 2. Revisión de la tecnología del riego para el establecimiento de brinzales .49

Tabla 1. Notación capítulo 2 .50

Tabla 2. Ecuaciones características de emisores no convencionales .54

Tabla 3. Comparación entre los distintos sistemas de riego a brinzales. .73

Capítulo 3. Ámbitos de estudio científico sobre la tecnología del riego para el establecimiento de brinzales

Tabla 1. Características de las bases de datos empleadas en la revisión sistemática de las publicaciones sobre micro-riego de brinzales y parámetros del algoritmo de clasificación de términos en los títulos.

Tabla 2. Temas de investigación en micro-riego y brinzales según revisión sistemática (1970-2017) .84

Capítulo 4. Eficiencia técnica de los sistemas de riego de brinzales. .89

Tabla 1. Listado de siglas utilizadas en el capítulo. . .90

Tabla 2. Costes y eficacia de aplicación de agua de los sistemas de riego de brinzales y de su fundamento hidráulico

Tabla 3. Costes y eficacia de aplicación promedio según el fundamento hidráulico ........95

Tabla 4. Criterios de clasificación de los grupos de mejora de los DMU de los sistemas de riego

Tabla 5. Tabla clasificatoria de los sistemas de riego y de su fundamento hidráulico (en negrita), para micro-riego y sistemas convencionales (en cursiva) según su eficiencia técnica global y pura, y grupos de mejora. 100

Capítulo 5. To replant or to irrigate: A silvicultural decision model for afforestation projects 107

Table 1. Brief description of some micro-irrigation systems for seedling plantation.. 111

Table 2. Notation .115

Table 3. Assumptions of the MThreshold Model.... 116

Table 4. Considered case studies. .117

Table 5. Input data and results of the model for the considered plantation designs ... 119 
Table 6. Range of the model's input variables and their effect on the value of $M$..........123

Adenda. Elementos de apoyo para la utilización del sistema de ayuda a la toma de

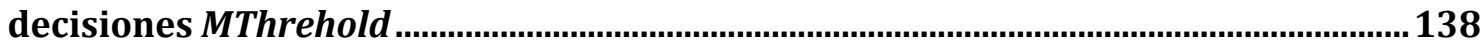

Tabla 1. Posibles causas de las marras en una repoblación forestal.....................................142

Tabla 2. Hipótesis de inferencia de la causa de la mortalidad a partir de los resultados del modelo MThreshold ...................................................................................................... 148

Capítulo 6. Herramienta informática para la integración económica del riego de

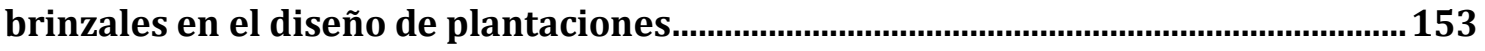

Tabla 1. Costes y parámetros del caso de estudio ………………………………………......162

Tabla 2. Resumen de los resultados del caso de estudio para los niveles de tolerancia de fallo. 163

Capítulo 7. Estimación del tamaño potencial del mercado de sistemas de riego de brinzales en plantaciones forestales en tierras áridas...............................................167

Tabla 1. Tamaños de mercado y crecimiento de varios sectores en el periodo 2016 a 2025

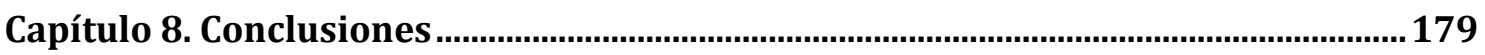

ANEJO 1. Relación de publicaciones realizadas como consecuencia de la tesis ........187 


\section{Lista de figuras}

Capítulo 1. ¿Riego de brinzales? Revisión crítica 1

Figura 1. Distribución mundial de zonas secas.............................................................................. 7

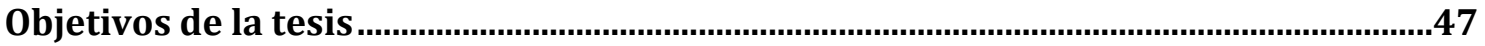

Capítulo 2. Revisión de la tecnología del riego para el establecimiento de brinzales

Figura 1. Sistemas de entrega de agua: a) Infiltración directa; b) Paredes porosas; c) Mecha de riego; d) Destilador solar .............................................................................................54

Figura 2. Riego subterráneo mediante un tubo vertical.........................................................55

Figura 3. Esquema con las piezas y conexiones de un Buried diffuser ${ }^{\circledR}$.................................57

Figura 4. El saco permeable Irrigasc …………………………………………………….....57

Figura 5. Tubería de drenaje de PVC corrugado......................................................................58

Figura 6. a) Recipiente de barro cocido utilizado en el riego por succión tradicional. Toda su superficie rezuma. b) Botella impermeable de plástico con un único rezumador circular.

Figura 7. Esquema del riego por succión ideado por Olguín (1975). Reelaborado a partir de un dibujo original del autor.

Figura 8. Cultivo de maíz con riego por succión mediante cápsulas porosas interconectadas con una tubería de plástico de $4 \mathrm{~mm}$ de diámetro. Foto de los primeros ensayos de campo, facilitada por Carlos Olguín Palacios.

Figura 9. Reservorio individual de exudación subterránea (RIES) con los dos rezumadores (flechas rojas), cedidas por Mario Matorel García.. . .62

Figura 10. Tubo protector artesanal y tapones de las cuatro botellas de un reservorio enterrado, cedidas por Mario Matorel García..

Figura 11. Pendiente (I) del eje hidráulico de tres mechas: a) Descendente (p. ej.: en el Waterboxx ${ }^{\circledR}$ ); b) Ascendente (p. ej.: en el Wickinator ${ }^{\circledR}$ ); c) Mixta sifón capilar (p. ej.: en el riego casero de tiestos) ...

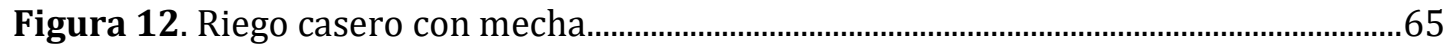

Figura 13. Recipientes con mecha: a) Botella PET; b) Vasija de barro ...................................66

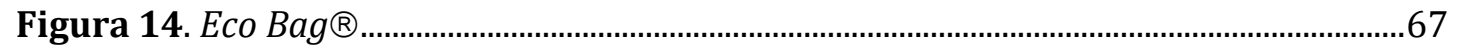

Figura 15. Perspectiva, planta y sección radial de una caja Waterboxx (ㄷ AquaPro) .....68

Figura 16. Destiladores solares para regar cultivos agrícolas alineados: a) Sistema patentado por Constantz (1991); b) Sistema de Ishimoto (1996). Reelaborado a partir de las figuras originales de ambas patentes...

Figura 17. Disposición de las dos botellas del Konkom indicando los parámetros y las variables principales de los que depende su funcionamiento . .70 
Capítulo 3. Ámbitos de estudio científico sobre la tecnología del riego para el establecimiento de brinzales

Figura 1. Evolución anual (1970-2017) de las publicaciones de micro-riego y brinzales

Figura 2. Mapa de términos en la base bibliográfica de Scopus . .83

Figura 3. Mapa de términos en la base bibliográfica de Google Scholar .83

Figura 4. Mapa de la distribución geográfica de temas tratados en las publicaciones sobre riegos de brinzales .85

Capítulo 4. Eficiencia técnica de los sistemas de riego de brinzales .89

Figura 1. Frontera de posibilidades de producción de los sistemas de riego y sus principios hidráulicos. . .97

Figura 2. Índices $V R S$ y $C R S$ para cada sistema de riego y fundamento hidráulico. . .98

Capítulo 5. To replant or to irrigate: A silvicultural decision model for afforestation projects . 107

Figure 1. Flowchart of the economic decision model based on variable $M$. 114

Figure 2. Position of the thirteen case studies in a coordinate system (C, R) grouped by grayscale. 122

Adenda. Elementos de apoyo para la utilización del sistema de ayuda a la toma de decisiones MThrehold. 138

Figura 1. Variación de $\varepsilon$ por especie a partir de datos de ensayos experimentales de Kowser (1978). 141

Figura 2. Convergencia de la simulación de Montecarlo para el modelo MThrehold...144

Figura 3. Función de distribución acumulada empírica de $M$. .145

Figura 4. Función de distribución acumulada empírica de M por grupo de aptitud.....147

Figura 5. Decisiones del modelo por grupos de aptitud al micro-riego... 147

Capítulo 6. Herramienta informática para la integración económica del riego de brinzales en el diseño de plantaciones.................................................................................153

Figura 1. Diagrama de flujo del sistema de decisión ..............................................................156

Figura 2. Aspecto visual del formulario de entrada/salida de datos de MThreshold versión 1 . 160

Capítulo 7. Estimación del tamaño potencial del mercado de sistemas de riego de brinzales en plantaciones forestales en tierras áridas. 167

Figura 1. Mapa de inversión anual (int\$) en reposición de planta en tierras áridas y en bosques plantados y frutales. Mapa superior referido al año 2016 y mapa inferior con la predicción del año 2025

Capítulo 8. Conclusiones 179

ANEJO 1. Relación de publicaciones realizadas como consecuencia de la tesis ........187 


\section{Resumen}

El micro-riego (o riego deficitario y localizado) es conocido desde hace más de dos mil años por las culturas fenicia, romana y china, aplicado a cultivos de huerta y a árboles frutales. Desde entonces y hasta nuestros días, ha ido extendiéndose y evolucionando tanto en el sector agrícola como en el sector forestal. En este último encuentra su principal aplicación en el establecimiento de brinzales, cuando la causa mayoritaria de mortalidad de las plantas sea el estrés hídrico. Las dudas técnicas y económicas que su aplicación suscita deben ser estudiadas y respondidas. La presente tesis doctoral realiza una exhaustiva revisión bibliográfica de los distintos sistemas de micro-riego forestal existentes, clasificándolos en base a su principio hidráulico de funcionamiento y su eficiencia técnica. Seguidamente, se desarrolla un modelo matemático con el que se obtiene el umbral de marras a partir del cual el micro-riego resulta ventajoso desde el punto de vista económico frente a la tradicional reposición de planta. El modelo se informatiza y se aplica a un amplio conjunto de casos de estudio de repoblación para analizar su utilidad y determinar la sensibilidad de sus diferentes parámetros de entrada. A continuación, se estima el tamaño y evolución del mercado internacional del micro-riego. Los resultados obtenidos con el modelo permiten al repoblador adoptar una decisión razonada respecto a la conveniencia (o no) de incluir riegos de apoyo en sus proyectos. También pueden orientar al fabricante de sistemas de micro-riego para fijar una oferta de precios que resulte atractiva al selvicultor.

Palabras clave: selvicultura, cuidados culturales, riego, establecimiento de plantaciones, reposición de marras, economía forestal, tamaño de mercado. 


\section{Abstract}

Micro-irrigation (localized and deficit irrigation) is a technique known since more than two thausand years by romans, chinese and phoenicians, applied mainly in horticulture and fruit trees. Since then the technique has been extending and developing either in agriculture or forestry. In the latter and in seedling establishment it's main aplication is found, when the main cause for seedling failure is hydric stress. Technical and economic doubts concerning the application of micro-irrigations must be studied and answered. The present doctoral thesis realizes an exhaustive bibliographical review of the different existing forest micro-irrigation systems, classifying them on base of their hydraulic principle and technical efficiency. Afterwards, a mathematical model is performed obtaining the threshold of seedling failure that defines the limit where microirrigation starts to be economically advantageous in comparison with the traditional technique of seedling replanting. The model is computerized and applied to a broad set of afforestation case studies in order to determine the scope of this model and the sensibility of the input parameters. Next, the size and international market evolution of micro-irrigation is assessed. The results obtained with the model allow the afforesters to adopt reasoned decissions concerning the convenience (or not) of the inclussion of seedling supporting irrigations in their projects. These outcomes can also orientate the manufacturers of micro-irrigation systems to establish product prices attractive for the silviculturist.

Keywords: silviculture, tending, irrigation, stand stablishment, replanting, forest economy, market size. 


\section{Presentación general de la tesis doctoral}

El mercado está desarrollando y comercializando tecnologías dirigidas a garantizar el establecimiento de los brinzales mediante sistemas de riego no convencionales aplicables en los proyectos de repoblación. Estos sistemas proporcionan micro-riegos que difieren en sus objetivos y tecnologías a los sistemas utilizados habitualmente en la agricultura. La utilización de esta tecnología es especialmente interesante en las tierras secas, donde las marras por estrés hídrico son la principal causa del fracaso de las plantaciones de árboles y arbustos, con mortalidades que superan en muchos casos el $40 \%$ de la densidad de la plantación.

Las evidencias obtenidas de los ensayos experimentales han mostrado la eficacia de la tecnología del riego para conseguir la supervivencia de las plantas en el establecimiento. A pesar de la capacidad de prueba a escala parcela, la difusión de la tecnología a escala monte provoca dudas. En primer lugar, porque añade un sobrecoste a la plantación que se enfrenta al statu quo técnico actual para tratar los fallos de las repoblaciones, que es la reposición de marras. En segundo lugar, por la ausencia de la información necesaria sobre el funcionamiento hidráulico de las tecnologías que oferta el mercado. Ambas cuestiones impiden conocer, a escala monte, si la tecnología es apropiada para conseguir el establecimiento de brinzales en los proyectos de plantación. Esta incertidumbre dificulta la adopción de la tecnología por gestores, propietarios y proyectistas y obstaculiza el desarrollo tecnológico. De lado de la oferta, la industria ve limitada la puesta en valor de las innovaciones y patentes debido a la insuficiente información para establecer una política de precios. Ambos grupos de actores se enfrentan al desconocimiento del campo de aplicación en el cual la tecnología del riego es ventajosa económicamente frente a la alternativa de reponer marras.

El primer capítulo sitúa la tecnología del riego de brinzales en la acción repobladora. En él, se valoran las incertidumbres sobre el uso del riego en las repoblaciones forestales y las directrices para el desarrollo de los sistemas de apoyo a la toma de decisiones, aplicados a la selección de cuidados culturales. La revisión crítica que se realiza en este capítulo define la estructura global y la finalidad de esta tesis doctoral.

La finalidad de la presente tesis doctoral es contribuir a despejar la incertidumbre sobre el uso del riego en la selvicultura. De acuerdo con ella, se definen una serie de objetivos que proporcionan los criterios de decisión hidráulicos, económicos y selvícolas para determinar qué tecnología de micro-riego puede ser aplicable a la selvicultura de la plantación de árboles y arbustos y cuándo es posible acudir, desde el punto de vista económico al riego, para conseguir el establecimiento de los brinzales en los proyectos de repoblación. 
En el segundo capítulo se definen las características propias del riego forestal y se describen los sistemas no convencionales según el fundamento de entrega de agua, sin perder de vista la comparación con las tecnologías tradicionales empleadas en el sector agrícola. A partir de esta revisión se propone una clasificación de las tecnologías existentes y se ofrecen unos primeros criterios que guíen la elección entre sistemas.

A continuación, el tercer capítulo, identifica los temas centrales abordados por la literatura científica en el periodo 1974-2016 en el estudio del riego de brinzales.

Una vez realizadas las revisiones anteriores, el cuarto capítulo plantea una evaluación comparativa de la eficiencia técnica global de los sistemas de riego utilizados en las plantaciones de brinzales. El análisis se aplica tanto a los sistemas como a los fundamentos hidráulicos de entrega de agua y ofrece recomendaciones a industriales y usuarios.

Los capítulos anteriores recopilan la información necesaria para identificar las variables incluidas en las ecuaciones que se presentan en el quinto capítulo. Este capítulo aborda la cuestión de cuándo elegir el riego frente a la alternativa de reponer marras; para ello, desarrolla un modelo de decisión económico y selvícola que compara ambas opciones. El modelo halla el valor del umbral de marras con el cual ambas alternativas ofrecen el mismo resultado económico y lo compara con las marras esperadas en la estación forestal. Esta regla proporciona un criterio aplicable a cada plantación y sistema de riego para decidir si regar o reponer planta en cada proyecto de repoblación. El modelo se aplica a trece casos de estudio y se realiza un análisis de sensibilidad de las variables y un análisis de incertidumbre que permite analizar las condiciones en las que, desde el punto de vista económico, el uso de riego es más ventajoso en las repoblaciones forestales que la gestión actual mediante reposición de marras.

En el sexto capítulo se presenta un programa informático para la integración económica del riego de brinzales en el diseño de plantaciones forestales a partir del modelo de decisión del tercer capítulo.

El séptimo capítulo estima el tamaño potencial del mercado de cuidados culturales y el micro-riego con sistemas no convencionales en tierras áridas.

El octavo capítulo presenta las conclusiones de este estudio y se responde a los objetivos de tesis.

La aplicación del riego es fácilmente comprensible en la agricultura y, sin embargo, es cuestionada en el sector forestal. La presente tesis doctoral aporta conocimientos innovadores en el sector selvícola relativos al uso del riego, en base a la resolución de la cuestión de cuándo utilizarlo en la plantación de brinzales, y contribuye a la comprensión del funcionamiento de la tecnología y del estado actual del mercado de los sistemas de micro-riego en la repoblación forestal. 


\section{Capítulo 1. ¿Riego de brinzales? Revisión crítica}

Este capítulo identifica los problemas más habituales relacionados con la gestión selvícola de la mortalidad de las plantas por estrés hídrico en los proyectos de repoblación forestal en tierras áridas, para dirigir a continuación su atención, a la incertidumbre que manifiestan gestores, proyectistas y otros actores en la utilización de los cuidados culturales, en especial con el riego, que es la medida más directa para conseguir la supervivencia de las plantas en esta situación. El capítulo se ha concebido como una revisión crítica del estado de conocimiento actual. Las conclusiones detectan las principales necesidades que justifican la presente tesis y la redacción de sus objetivos. 


\section{La difusión de las innovaciones agrarias}

La mortalidad de plantas por estrés hídrico disminuye con un diseño adecuado de los proyectos de repoblación y una ejecución correcta de todas las labores (Serrada et al., 2005). Cuando a pesar de estas precauciones las marras previstas son superiores a los niveles admitidos, el riego es el cuidado cultural más directo para asegurar la supervivencia de los brinzales por estrés hídrico. La eficacia de la técnica está probada, pero el sobrecoste que introduce en el proyecto de repoblación ha hecho que tradicionalmente se considere mejor alternativa acudir a la reposición de planta. La aplicación del riego es una medida que con carácter general se debe evitar y que se reserva a situaciones concretas, considerándose una actuación propia de una selvicultura intensiva con altas rentas (Hawkins et al., 2006; Keefe et al., 2012).

El párrafo anterior resume la práctica recomendable actual de utilización del riego en la gestión de marras por estrés hídrico en la repoblación forestal. Sin embargo, nuevos factores que han entrado en escena añaden mayor profundidad a la cuestión y están contribuyendo a modificar la percepción y actitud hacia el riego. Un síntoma de este proceso es que con frecuencia se observa, en los proyectos de plantación en tierras secas cuando hay agua disponible y accesible, la inclusión de la unidad de obra de riego que habitualmente es aplicada mediante camión cisterna o autobomba. Todos estos factores contribuyen a un aumento de la demanda de soluciones en plantaciones donde las técnicas tradicionales fracasan. Este cambio ha sido detectado del lado de la oferta donde el mercado comienza a proporcionar numerosas soluciones tecnológicas para abordar esta cuestión; de hecho, el riego no ha sido ajeno a esta tendencia y en los últimos años el mercado oferta soluciones tecnológicas específicas de riego localizado de brinzales dirigidas a los proyectos de plantaciones de árboles y arbustos. La incertidumbre técnica y económica sobre el uso del riego en los proyectos de repoblación forestal persiste y genera indecisión, opinión y debate.

Para conseguir una toma de decisiones informada sobre la aplicación del riego de brinzales en los proyectos de plantación de árboles y arbustos, es interesante adquirir una perspectiva amplia de las necesidades que tienen los actores implicados en conseguir la supervivencia de las plantas. En esta tarea son valiosas las aportaciones realizadas desde el ámbito de la difusión de la innovación agraria. La incertidumbre en la adopción tecnológica ha sido tratada ampliamente en la literatura científica de la innovación agraria (Schut et al., 2014). Esta disciplina muestra que la difusión de las nuevas tecnologías en el sector agrario, crece a un menor ritmo y requiere de mayor número de adoptantes para alcanzar una masa crítica de usuarios que en otros sectores. El riego agrario comparte esta tendencia general. Alcón et al. (2011) hallaron que la masa crítica de adopción tecnológica del riego localizado requirió del $25 \%$ de usuarios potenciales, frente al 5-10 \% habitual en sectores no agrarios. Los plazos de tiempo de adopción tecnológica también son más amplios. Como ejemplo baste citar los resultados del mismo estudio en los que el proceso de adopción precisó de 18 años para completarse. Para conocer las causas que explican la baja velocidad de difusión de la 
innovación del riego, se ha recurrido a los modelos de resistencia, aceptación, adopción y difusión tecnológica (Feder y Umali, 1993) buscando una explicación de la adopción, en número de adoptantes por unidad de tiempo, en función de la actitud hacia el uso y la utilidad percibida de la tecnología.

En el caso del riego agrario se han planteado hipótesis específicas para validarlo basadas en el concepto de resistencia o barreras tecnológicas (Lapointe y Rivard, 2005; Laumer y Eckhardt, 2012), bien sea del lado de la demanda (Foltz, 2003) o las que consideran también las del productor de tecnología (Long et al., 2016). Las evidencias experimentales muestran el elevado peso que tienen las hipótesis relacionadas con la restricción de capital y con los costes de aprendizaje frente a las demás (Alcón et al., 2011) y la relevancia de la acción conjunta de ambas, que facilita que aquellos que dispongan de mayor beneficio, o menor restricción presupuestaria en su cesta, y mayor cercanía espacial, accedan y adopten antes la innovación (Läpple et al., 2015; Läpple et al., 2016).

Los modelos de difusión de la innovación agraria han evolucionado para recoger la complejidad del proceso de adopción y ampliar la escala de trabajo a explotaciones, comunidades de usuarios, comarcas, países o regiones mundiales, en una progresiva incorporación de actores en red (Dearing, 2009; Schut, 2014). La hipótesis de costes de aprendizaje se ha ido enriqueciendo con todas estas contribuciones (Jensen, 1982; Dorfman, 1996; Foltz, 2003; Alcón, 2011; Kassie et al., 2013; Kassie et al., 2015; Samiee y Rezaei, 2017; Petridis et al., 2018) hasta enunciarla de manera detallada: Cuanto mayor es la cantidad, calidad y confiabilidad de la información y de la formación disponible, proporcionada por pares, por servicios de extensión y por especialistas, que faciliten los conocimientos necesarios para utilizar la tecnología y conocer las ventajas que proporciona, reforzados favorablemente por la persuasión práctica interpersonal, más pendiente tiene la curva de adopción de la innovación, porque hay menos incertidumbre.

Podría parecer que la adopción de la innovación agraria reduce, por tanto, la eliminación de la incertidumbre a un tema de comunicación e información entre productores y usuarios de tecnología. Esta visión general se matiza por dos cuestiones. En primer lugar, porque los sectores son heterogéneos y dentro de ellos existen grupos de usuarios que tienen distinta disposición a la innovación, a igualdad de factores relacionados, con la información por la restricción presupuestaria y por cuestiones culturales y sociodemográficas (Alcón et al., 2011; Cavallo et al., 2014; Petridis et al., 2018). En segundo lugar, porque intervienen más actores y se incorpora conocimiento tácito (Vandermeer y Perfecto, 2013; Schut et al., 2015a; Schut et al., 2016).

En este sentido la cuestión abierta es si la comunicación e información es más eficaz cuando es impulsada por la demanda, por la oferta, por ambas o por toda la red de actores implicados en el sistema sociotécnico. Este último enfoque, aportado desde la sociología de la ciencia y la tecnología, es con el que están trabajando varios autores (Klerkx et al., 2010; Schut, et al., 2015b) para determinar cuáles son los objetivos de la información, cómo proporcionarla y cuáles son las limitaciones a las que se enfrenta cada parte interesada. 
Algunas de las barreras que inhiben la adopción de la innovación están muy vinculadas con necesidades de información y economía. El trabajo de Long et al. (2016) identifica, en el marco de la agricultura climáticamente inteligente, las dificultades que tienen los productores y usuarios de la tecnología agraria. Los productores de tecnología requieren demostrar el valor y el impacto de su producto, conocer la posición con respeto a la competencia y acceder a los clientes. Del lado de la demanda, los usuarios manifiestan que tienen un bajo conocimiento de la tecnología y su impacto en el negocio; que tienen dificultades con la jerga técnica, que requieren capacitación en su uso y que necesitan probarlo para conocer su ajuste a la realidad del campo.

Especial consideración merecen los temas económicos del coste, el retorno de la inversión y su distribución en la cadena productiva de las innovaciones agrarias de riego (Wichelns, 2007; Alarcón et al., 2016). En los entornos áridos, con riesgos en la producción, los productores son favorables a aceptar el sobrecoste si se asegura la producción (Alcón et al., 2014) mientras que en otras geografías muestran preocupación porque la demanda sea sensible a modificaciones del precio vía etiquetado (Long et al., 2016).

La revisión de las limitaciones y las necesidades de información en la adopción de la innovación agraria puede ser aplicable al sector forestal, pero sólo parcialmente. Ambos sectores, agrario y forestal, comparten el mismo espacio de trabajo (entorno rural y sus ecosistemas) tienen distintos objetivos y, sobre todo, una economía subyacente muy dispar. Plazos, costes, retornos, externalidades y que estructuralmente se vea dominada por el proveedor de la oferta de bienes y servicios en el caso forestal, son algunas de estas diferencias (Weiss, 2011). ¿Cuáles son, por lo tanto, las necesidades de información para la toma de decisiones sobre el riego de brinzales en los proyectos de repoblación? Siguiendo el listado de las fuentes de incertidumbre propuestas por Meijer et al. (2007) y Klerkx et al. (2010) y la revisión efectuada en este capítulo, se acotan las fuentes de incertidumbre sobre la aplicación del riego en las plantaciones de árboles y arbustos (Tabla 1). 
Tabla 1. Fuentes de incertidumbre del riego de brinzales

\begin{tabular}{ll}
\hline Tipo de Incertidumbre & Temas sobre los que hay incertidumbre \\
\hline Incertidumbre del recurso & Las marras por estrés hídrico \\
\hline Incertidumbre competitiva & $\begin{array}{l}\text { La gestión de marras: preparación del terreno, reposición } \\
\text { de planta, cuidados culturales y riego }\end{array}$ \\
\hline Incertidumbre tecnológica & Características del riego forestal \\
\hline Incertidumbre del proveedor & Costes y eficacia de los sistemas de riego \\
\hline Incertidumbre del consumidor de cada sistema de riego \\
Tamaño del mercado y su crecimiento \\
\hline Posibilidad de elegir opciones alternativas \\
\hline $\begin{array}{l}\text { Preferencias de los consumidores con respecto a la } \\
\text { innovación }\end{array}$ \\
\hline
\end{tabular}

Al estado de conocimiento de estas incertidumbres se dedican los siguientes apartados para conocer cuáles son los elementos que definen el problema de la decisión alrededor de la aplicación del riego de brinzales.

\section{Las marras}

\subsection{La importancia de las marras}

La mortalidad de los brinzales (marras) continúa siendo uno de los principales desafíos científicos y técnicos en las plantaciones forestales (Cortina et al., 2004) y en la regeneración natural (Calama et al., 2017a). La ciencia se enfrenta al reto de comprender cómo se producen y cuál es su origen para poder predecirlas, y la técnica se enfrenta al desafío de diseñar y ejecutar las intervenciones necesarias para reducirlas hasta conseguir la densidad o los niveles de reclutamiento necesarios para conseguir el establecimiento de las plantas.

Para ilustrar la preocupación de científicos e ingenieros españoles «sobre las causas de las marras» baste señalar que este fue el título de la primera reunión del grupo de trabajo de repoblaciones forestales de la Sociedad Española de las Ciencias Forestales, celebrado en Madrid en junio del año 1996. Este hecho cobra especial relevancia por la larga tradición repobladora existente en España que «con una base científica y realizada por personal técnico formado al efecto, lleva desarrollándose desde el año 1879» (Pemán y Vadell, 2009).

El motivo de este interés no es accidental sino que se debe a que la incertidumbre sobre la causa y la cuantía de las marras dificulta o impide: i) el control de las labores de repoblación y su certificación (Serrada et al., 2005), ii) determinar la calidad de las repoblaciones (Gómez y Elena, 1997; Serrada et al., 2005), iii) la prevención de las marras (Serrada et al., 2005), iv) acotar el éxito previsto en las repoblaciones, en especial en condiciones de aridez (Holl y Howarth, 2000; Navarro et al., 2009; Vallejo et al., 2012), v) 
evaluar la eficacia de algunas técnicas y prácticas de repoblación (Thayer et al., 2003; Saldi et al., 2004; Serrada et al., 2005), vi) y a la mejora de los cuidados culturales tras la plantación o su elección (Maestre et al., 2003). Además, la incertidumbre inicial de su valor se propaga en el tiempo cuando se evalúa la masa forestal a largo plazo como sucede en los modelos de crecimiento (Sims et al., 2009) o en la economía forestal centrada en fijar el turno de corta óptimo.

La preocupación por las marras causadas por estrés hídrico trasciende los ámbitos tradicionales de proyectos técnicos y estudios científicos para adentrarse en la política internacional. La mortalidad de las plantas se produce principalmente en las tierras áridas del planeta (Figura 1), donde habitan 2.100 millones de personas en aproximadamente 110 países, cubriendo el 41,3\% de la superficie de la Tierra (UNCCD, 2017).

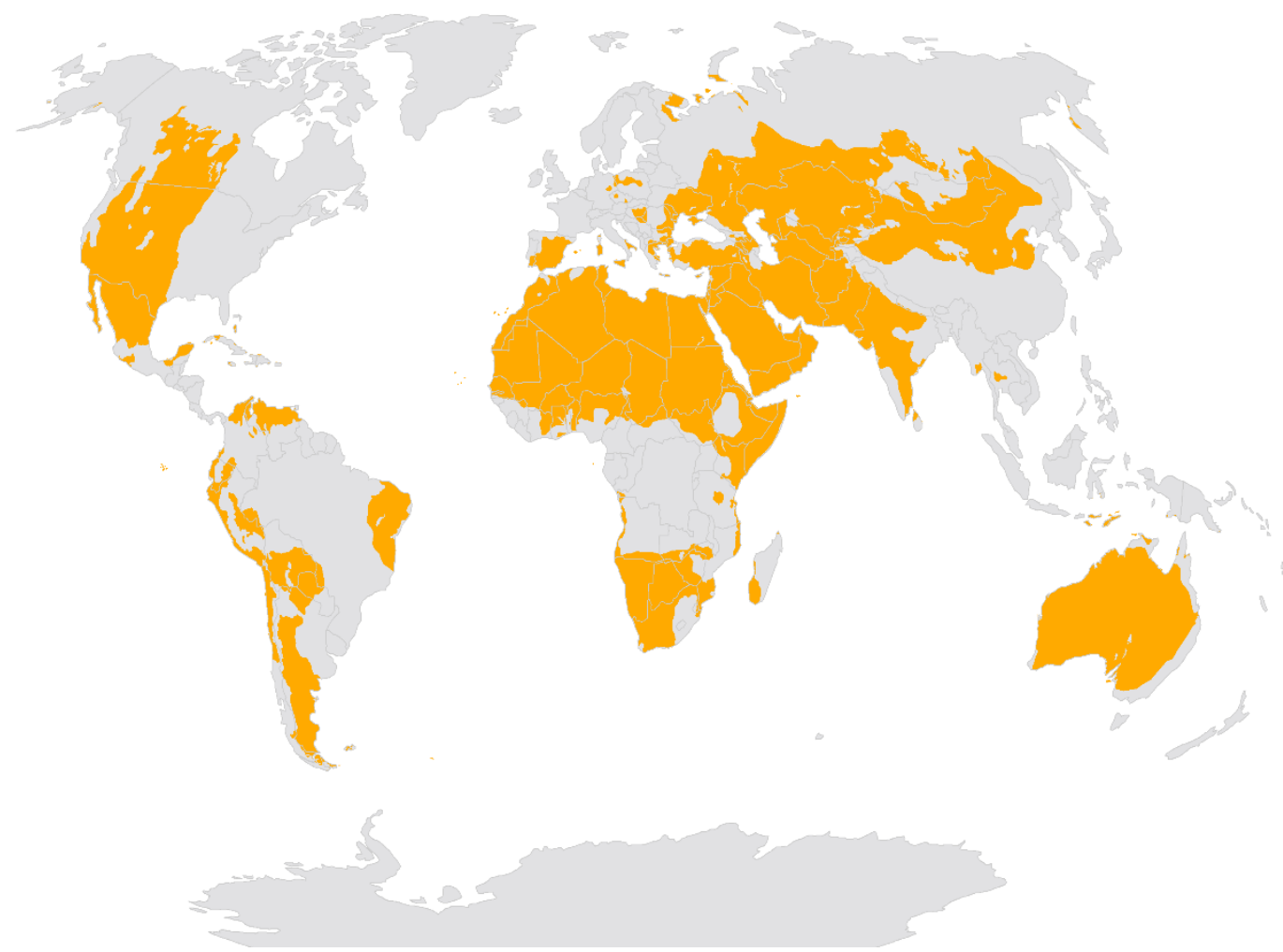

Figura 1. Distribución mundial de zonas secas

El objetivo de la Agenda 2030 para el desarrollo sostenible promulgado por Naciones Unidas (Naciones Unidas, 2015) establece en su objetivo número quince, restablecer el uso sostenible de los ecosistemas terrestres, luchar contra la desertificación, detener e invertir la degradación de las tierras y detener la pérdida de biodiversidad. Para conseguirlo, fija las siguientes metas de aquí al año 2020: el restablecimiento de los ecosistemas terrestres en particular bosques y zonas áridas (15.1.) y recuperar los bosques degradados y aumentar considerablemente la forestación y la reforestación a nivel mundial (15.2.). Para ello, prevé 
movilizar y aumentar significativamente los recursos financieros procedentes de todas las fuentes (15.a.) y proporcionar incentivos adecuados a los países en desarrollo para que promuevan dicha gestión, en particular con miras a la conservación y la reforestación (15.b.).

A pesar de la relevancia de las marras afirmada por la comunidad científica, a la importancia concedida a su gestión por la ingeniería y al reconocimiento por parte de las políticas internacionales, como condicionante del desarrollo, no se dispone de estadísticas internacionales sobre marras que proporcionen información sobre el tamaño del problema. Sólo se cuenta con fuentes de datos indirectos facilitados por algunos países que han registrado la superficie en la que se realiza reposición de planta cuando se producen marras. En la dilatada experiencia forestal española, con cerca de 5,4 millones de hectáreas repobladas en los últimos 70 años (Pemán y Vadell, 2009), los estudios realizados por Vadell et al. (2016) a partir de las estadísticas oficiales estiman que la superficie en la que se ha practicado la reposición de marras es de 0,86 millones de hectáreas. En otros países del ámbito mediterráneo como Turquía, también se dispone de datos: se replantaron 0,30 de los 0,87 millones de hectáreas reforestadas en el periodo 2002 a 2012 (Çalişkan y Boydak, 2017).

Las marras, o su medida complementaria, cantidad de brinzales que sobreviven, continúa siendo el estándar técnico aceptado para medir el cumplimiento de este objetivo inicial de la plantación (Serrada et al., 2005; Maestre y Cortina, 2004; Vallejo et al., 2012) y un indicador muy difundido en el control de calidad de los trabajos de plantación efectuados. En la actualidad, el porcentaje de marras se utiliza también para determinar si es necesario replantar (reponer marras) lo cual sucede cuando los valores observados de marras son superiores al nivel admisible de marras (Serrada et al., 2005).

\subsection{Las múltiples e insuficientes cuantificaciones de las marras por estrés hídrico}

Los valores bibliográficos de referencia recopilados en España por Pemán y Vadell (2009) indican una gran variabilidad en las marras esperadas, según diferentes factores, entre los que destacan el método de repoblación, las especies, la preparación del suelo, los trabajos culturales, el tipo de planta y el medio donde se realiza la repoblación. La respuesta de la planta al establecimiento depende, por lo tanto, de varios factores relacionados cuya importancia relativa en la supervivencia final varía en función de las condiciones del lugar de plantación (estación forestal), de las técnicas empleadas (Navarro et al., 2006) y de la especie (Pemán et al., 2006).

En las repoblaciones no es posible determinar las causas de las marras mediante parcelas de conteo sin acudir a controles sistemáticos de todos los trabajos de la plantación (Serrada et al., 2015) para discernir el valor concreto de las marras producidas por estrés hídrico. El análisis de las observaciones efectuadas en los estadillos de las parcelas de conteo, al igual que el diseño experimental minucioso con parcelas de contraste, constituyen técnicas útiles para resolver esta situación. Sin embargo, estos datos no siempre existen por lo que, en ausencia de ellos, la línea de trabajo basada en 
patrones espaciales y temporales de mortalidad de las repoblaciones constituye una fuente de datos complementaria (Cortina y Vallejo, 1999). En la investigación de la regeneración natural los esfuerzos se han centrado preferentemente en ensayos experimentales para determinar las probabilidades de supervivencia según diversos factores (Castro et al., 2004; Maestre et al., 2003; García y Houle, 2005; Manso et al., 2013).

En lo que coinciden los estudios experimentales es en destacar que uno de los principales responsables del fracaso en el arraigo y primer desarrollo de las plántulas en repoblaciones y plantaciones en zonas áridas, es el estrés hídrico (p. ej., Burdett, 1990; Margolis y Brand, 1990; Moles y Westoby, 2004). Este factor es especialmente patente en regiones con sequía fisiológica durante el periodo vegetativo, como es el caso habitual de muchas de las zonas áridas (Figura 1) incluidas las de clima mediterráneo (p. ej., Herrera, 1992; Maestre et al., 2003).

Los datos muestran que las marras por estrés hídrico son mayores en el primer año de plantación (Gao et al., 2002; Maestre et al., 2003; Rey y Camacho, 2004; Bocio et al., 2002; Vallejo et al., 2005).

En ausencia de estadísticas que desglosen las causas, la primera dificultad práctica para el proyectista es averiguar el valor de las marras por estrés hídrico de una estación forestal. En los proyectos de forestación en climas áridos o semiáridos a menudo se contempla, ya en sus diseños iniciales, una tasa de mortalidad de plantas superior al 30\% (Chunfeng y Chokkalingam, 2006) o incluso por encima del 40\% (Pemán y Vadell, 2009; Çalişkan y Boydak, 2017). Estos valores pueden verse modificados según el momento de la plantación y la calidad del sitio. Navarro et al. (2014) hallaron variaciones del $18 \%$ y del $13 \%$ respectivamente, debido a estos factores. Aunque estas cifras ilustran la extensión del problema, carecemos en la actualidad de datos que ofrezcan una visión global del mismo.

Algunos autores han detectado que las variaciones anuales de las marras son del orden de siete veces más importantes que las espaciales (Beckage et al, 2005). Esta evidencia conduce a considerar las consecuencias del cambio climático en las marras por estrés hídrico. Las previsiones de cambio climático de aumento de la evapotranspiración potencial y de la duración de la sequía, implicarán un aumento de las marras por estrés hídrico. Martínez-Vilalta et al. (2002) cuantifican, en 90 días de sequía para Quercus ilex, un aumento de las marras esperadas, $\Delta M_{R}=4 \%$ en el escenario de incremento de la temperatura media anual de $3^{\circ} \mathrm{C}\left(T+3^{\circ}\right)$, y un $\Delta M_{R}=8 \%$ (en el escenario $T+4,5^{\circ}$ ). En sequías de larga duración el modelo de estos autores predice que la mortalidad se verá incrementada rápidamente. Cifras de $M_{R}=50 \%$ se obtienen en sólo 127 días de sequía (en el escenario $T+4,5^{\circ} \mathrm{C}$ ) frente a los 145 días que son necesarios en la actualidad ( $T$ ).

El tamaño del mercado de las marras también es un ámbito no tratado en las estadísticas oficiales internacionales. La inversión que se realiza a nivel mundial en las plantaciones, puede ofrecer algunas orientaciones sobre el orden de magnitud del mercado global de la reposición de marras, no sin antes establecer numerosas hipótesis y supuestos de cálculo. A pesar de las claras limitaciones de esta metodología, las bases 
de datos accesibles sobre frutales y plantaciones permiten estimar un valor orientativo del tamaño potencial del mercado de cuidados culturales orientados a la gestión de marras por estrés hídrico en las tierras secas. La ausencia de bases de datos internacionales con información sobre otros tipos de plantaciones, repoblaciones, restauraciones, ayudas a la regeneración natural o la falta de la repercusión del cambio climático sobre las marras, induce a pensar que las cifras que se puedan obtener sean conservadoras e infravaloren las cifras reales.

La trascendencia de la supervivencia de los brinzales en el establecimiento ha influido en que el esfuerzo científico centre su atención en predecir la cuantía de las marras por estrés hídrico, principalmente desde el área de estudio de la regeneración natural (Miina y Skasa, 2008; Manso et al., 2013). Varios tipos de modelos se están proponiendo para resolver esta cuestión. Un primer grupo recurre a modelos de predicción de la mortalidad de base empírica que relacionan las marras observadas con variables predictoras climatológicas y edáficas (Gómez y Elena, 1997; Alloza y Vallejo, 1999; Gómez et al., 2008) que ligadas a patrones topográficos, condicionan la disponibilidad hídrica de la planta (Navarro et al., 2014; García et al., 2018). Sin abandonar el enfoque empírico, un segundo grupo incorpora la probabilidad mediante funciones de distribución (Sánchez et al., 2006; Pardos et al., 2015) y un tercer grupo incorpora los procesos fisiológicos involucrados en la mortalidad de los brinzales durante la sequía (McDowell et al., 2008; Calama et al., 2015) para plantear modelos predictivos (Martínez-Vilalta et al., 2002; Calama et al., 2015). Este último grupo de modelos basados en procesos fisiológicos son los que mejores resultados obtienen en las pruebas estadísticas de validación, si bien, su transferencia es compleja por la obtención de las variables predictoras que precisan, las cuales, son de difícil obtención y medición en la gestión cotidiana.

Las fases de diseño y ejecución del proyecto de repoblación permiten un gran control de las marras que no tiene su origen en el estrés hídrico; por este motivo no es de extrañar que el valor de las marras sea el criterio técnico o estándar más extendido en la evaluación inicial del éxito de las repoblaciones.

\section{La gestión de las marras por estrés hídrico}

La práctica profesional establece que, si el proyecto está bien diseñado y ejecutado, las únicas marras importantes serán las debidas a la variabilidad de la lluvia. Esta mortalidad por estrés hídrico se puede gestionar mediante la preparación del terreno y los cuidados culturales, con el fin de conseguir y/o asegurar la supervivencia y crecimiento inicial acorde a los objetivos establecidos en la plantación forestal.

\subsection{La preparación del terreno}

La preparación del terreno homogeniza la variación local de la fisiografía (Del Campo et al., 2004). Esta sistematización (del terreno) facilita que las plantas sobrevivan a la escasez de agua en la primera estación seca, siendo este factor clave en la 
supervivencia de las plantas en regiones áridas y semiáridas (Rey y Camacho, 2004; Bocio et al., 2002; Vallejo et al., 2005).

En zonas áridas, la estrategia repobladora clásica para disminuir la mortalidad por sequía se centra en la preparación del terreno que, desde un punto de vista hidrológico, persigue dos objetivos fundamentales: sistematizar el terreno para aprovechar y concentrar la escorrentía superficial y modificar las características edáficas en términos de un aumento de la capacidad de retención de agua del perfil. De esta forma se consigue un mejor aprovechamiento de los pulsos hídricos -erráticos e intensoshabituales en estas zonas (Ludwig y Tongway, 1997). Esta alteración del terreno se traduce en una «oasificación» que disminuye la severidad y la duración de la sequía (Martínez de Azagra, 1994, 2002; Löf et al., 2012). Desde el punto de vista de la supervivencia de los brinzales, la preparación del terreno busca conseguir que coincida la mayor disponibilidad hídrica posible con el momento en que está programada genéticamente la elongación radical. Ese momento se produce antes del periodo seco, al finalizar la primavera y comenzar el verano (Joslin et al., 2000).

Las preparaciones del terreno ofrecen distinta disponibilidad hídrica según la sistematización que plantean (Martínez de Azagra, 1994; Martínez de Azagra et al., 2004). Los ensayos experimentales muestran que las preparaciones del terreno correctamente dimensionadas, proporcionan habitualmente mayor disponibilidad hídrica a las plantas y mejoran la supervivencia de las plantas obtenidas (De Simón et al., 2006). Querejeta et al. (2001) encontraron diferencias de marras del 36\% entre terrazas mecanizadas y manuales. García et al. (2018) descubrieron diferencias del 54\% en microcuencas y del $10 \%$ en terrazas, con respecto a parcelas de control en las que no se había efectuado preparación del terreno alguna.

Las preparaciones del terreno facilitan la penetración mecánica de la raíz hacia horizontes edáficos profundos (Querejeta et al., 2001). La planta alcanza su autonomía hídrica cuando el sistema radical profundiza en el suelo y alcanza horizontes con mayor contenido de agua; a partir de ese momento la planta tendrá acceso al agua durante la temporada seca. De esta manera se disminuye las marras siempre y cuando el contenido de humedad del suelo sea superior a determinados límites (Padilla y Pugnaire, 2007; Khamzina et al., 2008).

Aun cuando las preparaciones del terreno estén correctamente diseñadas y realizadas, en repoblaciones bajo clima árido es común contar, ya en el propio diseño y proyecto de las mismas, con mortalidades de plántulas elevadas ante la ausencia de las siempre aleatorias lluvias o cuando las precipitaciones son débiles y no superan los umbrales de escorrentía.

La ausencia de lluvias tendrá distintos efectos sobre la supervivencia según la especie y el momento en el que se produzcan las lluvias. En clima mediterráneo, las precipitaciones del período húmedo constituyen la reserva de agua del suelo con valores próximos a la capacidad de retención de agua del suelo, lo que reduce la duración de la sequía (Querejeta et al., 2001). Las precipitaciones de los episodios tormentosos del 
verano disminuyen la severidad de la sequía. Las precipitaciones de primavera y comienzo del verano son las que facilitan el crecimiento radical de manera que las plantas consigan la profundidad suficiente para alcanzar los horizontes húmedos antes del primer verano (Padilla y Puignare, 2009; León et al., 2011; Navarro et al., 2006). Por este motivo, las plantaciones tempranas tienen mejor supervivencia que las tardías (Palacios et al., 2009; Potts et al., 2010; Navarro et al., 2014).

En la regeneración natural de las especies adaptadas a estaciones de clima extremo en la región árida (p. ej. Abdoun y Beddiaf, 2002; Van Jaarsveld y Pond, 2013) esperan hasta que se produzcan las condiciones óptimas, una ventana de oportunidad (Manso et al., 2013) para que la regeneración sea un éxito. La alta variabilidad interanual de las precipitaciones hace que la ventana de oportunidad necesaria para la supervivencia de los brinzales en una estación, no coincida necesariamente con el año en el que se realiza la plantación. La falta de sincronía explica que, a pesar del correcto diseño y ejecución de la plantación, se obtengan en la práctica valores altos de marras en las tierras secas. El registro histórico de marras altas en la repoblación son un indicador de la existencia de ventanas de oportunidad (Padilla y Puignare, 2009).

\subsection{La reposición de marras}

Esta técnica consiste en la sustitución de las plantas muertas o ausentes por nuevos ejemplares en las mismas condiciones que las definidas para la plantación original, es decir, especie, procedencia, tipo de planta, edad, época de plantación, porcentajes, densidades, disposición en el lugar idóneo, posición vertical, correcto enterramiento o resistencia al arranque entre otras. La reposición se lleva a cabo de forma manual, aunque la plantación original haya sido mecanizada, para evitar daños a las plantas que han arraigado y se encuentran en buen estado (JCYL, 2007). La reposición se realiza durante los primeros años tras la repoblación hasta que se alcanza el nivel admisible de marras conforme a los fines de la restauración (Serrada et al., 2005).

Tradicionalmente, el fracaso en el establecimiento de brinzales por causa del estrés hídrico se ha venido corrigiendo mediante la técnica de reposición de planta. Esta técnica es el statu quo técnico para gestionar las marras por estrés hídrico por su bajo coste y facilidad de aplicación en función de las condiciones del año. La técnica de reposición de marras es una de las actividades de seguimiento y cuidado fundamentales tras la realización de las repoblaciones forestales (Serrada et al., 2005), especialmente en zonas de clima semiárido donde la elevada mortalidad inicial de las plantas es uno de los limitantes principales de la repoblación (Cortina et al., 2004). En ambientes mediterráneos, el indicador de seguimiento más usado en las repoblaciones forestales se basa en los conteos iniciales de mortalidad de las plantas (Maestre y Cortina, 2004), los cuales se comparan con el nivel admisible de fallos o marras (Serrada et al., 2005) con el fin de evaluar el éxito de la repoblación. Los conteos se realizan durante todos los años en los que se practica la reposición de marras.

La estrategia de reposición de planta no siempre ofrece resultados satisfactorios. Algunas desventajas que ponen de manifiesto varios autores son las siguientes: i) el 
aumento del coste de los trabajos de repoblación (Pemán y Vadell, 2009), ii) que existen lugares donde la repoblación forestal con técnicas clásicas fracasa, a los que Ruiz de la Torre et al. (1996) denominan área crítica; en ellos, el coste de establecimiento es elevado (Vallejo et al., 2012). iii) Hay incertidumbre en los resultados del establecimiento de la plantación por la variabilidad de las precipitaciones y los escenarios de cambio climático (Pasalodos et al., 2013), iv) posible riesgo de incurrir en un sobrecoste por la reposición de planta (Ahtikoski et al., 2010; Del Río et al., 2018), v) posibilidad de incurrir en retrasos en el establecimiento de las plantas, en la percepción de ingresos, en la recuperación de bonos y garantías y en la aparición de lucro cesante (Sullivan y Amacher, 2013; Del Río et al., 2013), vi) posibles daños por la mortandad de brinzales cuando la plantación tiene una finalidad protectora de infraestructuras (Serrada, 2004).

\subsection{Los cuidados culturales}

Las medidas de apoyo al establecimiento de brinzales son tratamientos o técnicas selvícolas de cuidado de las plantas recién instaladas en campo para conseguir su arraigo, supervivencia o facilitar su crecimiento inicial. Las medidas de apoyo se usan en plantaciones forestales y restauraciones ecológicas (Stanturf et al., 2014). Es habitual observar que reciben el nombre de cuidados culturales cuando son utilizados en plantaciones industriales, forestaciones y reforestaciones (Serrada, 2004). Cuando se emplean en plantaciones o actuaciones que tiene como objetivo el apoyo de la regeneración natural (Ganz y Durst, 2003; Shono et al., 2007) o la restauración ecológica, es habitual observar como la literatura se refiere a ellas como medidas de acompañamiento. En esta tesis se va a adoptar la denominación de cuidados culturales. La finalidad principal de los cuidados culturales (CC) es lograr la superveniencia (Vallejo et al., 2002) y/o el crecimiento inicial de los brinzales (Dey et al., 2008) mediante la eliminación o reducción de las barreras abióticas y/o bióticas a la plantación o la regeneración natural (Ciccarese et al., 2012). Se considera que se ha alcanzado el objetivo del establecimiento cuando se consigue la autonomía de la planta y puede competir con éxito con la vegetación circundante (Johnson et al., 2002) para alcanzar un estatus dominante en la masa (Dey et al., 2008).

Los cuidados culturales se aplican en los proyectos de repoblación para conseguir la supervivencia de las plantas, en estaciones con condiciones adversas, cuando es posible identificar la causa de la mortalidad (Oliet y Jacobs, 2012), en especial, si las marras observadas son elevadas, persistentes en el tiempo y el daño provocado por la mortandad tiene graves consecuencias (Tabla 2). En esta situación, el procedimiento de trabajo más habitual es recurrir a la aplicación de cuidados culturales que corrijan el problema detectado, habitualmente aplicados con posterioridad la plantación (Löf et al., 2012).

Las áreas de trabajo de la xero-jardinería, regeneración natural, protección de infraestructuras, restauración ecológica, plantaciones de enriquecimiento y de las plantaciones de diversificación, también están dirigiendo su atención a los cuidados culturales por el coste de la planta, por la dificultad del establecimiento y por el elevado 
lapso de tiempo necesario para alcanzar sus objetivos (Dey et al., 2008; Rey et al., 2015; Martínez de Azagra y Del Río, 2012).

El sobrecoste de los cuidados culturales y su repercusión económica en la viabilidad del proyecto al realizarse en los primeros años del ciclo de vida de una plantación forestal (Mangaoang, 2002; Hepburn y Koundouri, 2007), ha conducido a considerarlos por algunos autores una práctica propia de la selvicultura intensiva, cuyo gasto solo está justificado en la implantación vegetal de la que se espera obtener una elevada renta (Busby et al., 1998; Dubois et al., 2001; Hawkins et al., 2006).

Esta visión ha persuadido a técnicos y propietarios de utilizar los cuidados culturales en el establecimiento de brinzales en extensiones amplias, especialmente en las tierras secas (dryland) en las que los ingresos por unidad de superficie son habitualmente bajos y las plantaciones se llevan a cabo con presupuestos ajustados (Hochstrasser et al., 2014). También ha sucedido así en otros ámbitos de la gestión forestal donde el valor en el mercado de los productos, funciones o servicios de bosque es escaso, como por ejemplo en los bosques protectores, en las restauraciones ecológicas, en la xero-jardinería o en el xero-paisajismo.

Sin embargo, hay un resultado contra-intuitivo: el coste final de la plantación o el coste por planta conseguida, puede verse disminuido por la utilización de cuidados culturales (Dey et al., 2008). La literatura destaca los siguientes factores para explicar este resultado. En la escala de proyecto, algunas técnicas de gestión de marras como la sobreplantación (Dean y Chang, 2002) o la reposición continuada de plantas (Löf et al., 2012) no son eficaces económicamente. En años de precipitación débil la elección de planta y la preparación del terreno no garantizan el éxito del establecimiento (Vallejo et al., 2012). La escala de país está proporcionando estadísticas sobre la cuantía, superficie e importancia económica de las marras desde varias geografías de las tierras áridas que ofrecen una idea de la extensión y repercusión del problema (Pemán y Vadell, 2009; Chunfeng y Chokkalingam, 2006; Çalişkan y Boydak, 2017). En escalas supranacionales destaca la incertidumbre sobre el resultado del establecimiento de plantas por efecto de las previsiones de los escenarios de cambio climático en la supervivencia de los brinzales (Beckage et al., 2005; Martínez-Vilalta et al., 2002; Pasalodos et al., 2013).

El mercado está aumentando la oferta de tecnología asociada a los cuidados culturales (Vallejo et al., 2012; Cortina et al., 2011; Pausas et al., 2004). Esta tendencia es un indicio del cambio de percepción sobre los cuidados culturales. La literatura explora los siguientes motivos: i) la incorporación de los servicios de regulación y culturales en la valoración económica incrementa la renta de las plantaciones y justifica mayores inversiones iniciales (Robbins y Daniels, 2012; Duke et al., 2013; Hsu y Loomis, 2002), ii) la eficacia elevada de los cuidados culturales para conseguir la supervivencia inicial de los brinzales (Dey et al., 2008), iii) los requerimientos de estrictos niveles de supervivencia y/o cortos plazos exigidos para conseguir el establecimiento, iv) las marras esperadas, inicialmente elevadas en determinadas estaciones críticas (Ruiz de la Torre et al., 1996; Dey et al., 2008; Navarro et al., 2014), v) el aumento de la oferta de 
soluciones técnicas que ofrece el mercado de cuidados culturales, vi) y que existe una posible falta de eficiencia económica de la aplicación a posteriori de los cuidados culturales una vez que se han producido las marras (Löf et al., 2012).

Se han realizado numerosos estudios sobre la eficacia en las plantaciones de uno o varios cuidados culturales simultáneos y/o posteriores al establecimiento (Reque y Bravo 1993; Peñuelas et al., 1996; Lemieux y Delisle, 1998; Rey et al., 2002; Rey y Camacho, 2004; Rey et al., 2005; Rey et al., 2008; Badano et al., 2009; Palmerlee y Young, 2010; Kribeche et al., 2012; Ceacero et al., 2014; Pardos et al., 2015). Estos estudios muestran que los cuidados culturales reducen la mortalidad de las plantas sustancialmente (Vallejo et al., 2012) y ofrecen buenos ratios beneficio/inversión (Rey y Camacho 2004; Dey et al., 2008).

Las técnicas aplicadas comúnmente para disminuir la mortalidad de plántulas por estrés hídrico son: el riego, el control de la vegetación competidora (especialmente herbácea), la utilización de protectores capaces de propiciar a la plántula un microambiente hídrico más favorable y la simple protección de la base de la plántula con piedras o acolchado ( $m u l c h)$ para disminuir la evaporación de agua del suelo y la competencia herbácea (Reque y Bravo, 1993; Jiménez et al., 2013; Noelia et al., 2016).

En determinados ambientes y especies se logran mayores supervivencias cuando se combinan cuidados culturales. En el caso del estrés hídrico la combinación más ensayada es el riego y acolchado (Pardos et al., 2015). Los resultados muestran que provocan un aumento de la disponibilidad hídrica y una reducción de la insolación (Rey, 1998; Sack y Grubb, 2002) que concuerda con la modificación de los factores fisiológicos implicados en la mortandad por estrés hídrico (Calama et al., 2015), si bien, el efecto aditivo sobre la supervivencia no se ha hallado (Pardos et al., 2015). El riego es el cuidado cultural más directo para evitar las marras por estrés hídrico.

La ausencia de cuidados culturales provoca marras en las plantaciones (Navarro y Martínez, 1997), ralentiza la expansión del bosque a partir de plantaciones islas con marras del 96,9\% (Rey et al., 2015) y provoca un espejismo de abaratamiento de costes de la repoblación (Löf et al., 2012; Del Río et al., 2013). A pesar de estas evidencias, para alcanzar las metas de la plantación es necesario trasladar los resultados experimentales a escalas más amplias (Suding, 2011; Cortina et al., 2011) mediante un listado claro y completo de las técnicas disponibles (Hobbs y Harris, 2001; Serrada et al., 2005) y de las herramientas que orienten cuantitativamente, en términos económicos, la selección entre los cuidados culturales disponibles para superar las limitaciones en el establecimiento de las plantas (Matthews et al., 2009; Rodrigues et al., 2009; Cortina et al., 2011). 
Tabla 2. Cuidado cultural aplicable en función de la causa de la mortandad de brinzales

\begin{tabular}{|c|c|}
\hline Causa & Cuidado cultural \\
\hline \multirow{3}{*}{$\begin{array}{l}\text { Estrés hídrico: falta de agua, sequía extrema (muy } \\
\text { mal año meteorológico; escasas lluvias y cosechas de } \\
\text { agua) }\end{array}$} & Riego \\
\hline & Acondicionadores \\
\hline & Acolchado \\
\hline $\begin{array}{l}\text { Errónea elección de especies y/o ecotipos: } \\
\text { procedencias equivocadas para la estación forestal }\end{array}$ & \\
\hline $\begin{array}{l}\text { Mala calidad de planta: poco cepellón, plantas sin } \\
\text { endurecer, mal nutridas, sin micorrizar, enfermas, } \\
\text { etc. }\end{array}$ & \\
\hline
\end{tabular}

Herbicidas

Incorrecta preparación del suelo: desbroce escaso, Escardas, binas poco volumen de suelo removido, mal tempero al realizar la labor, alcorque pequeño, área de impluvio insuficiente, etc.
Bainbridge et al. 1995, Bainbridge 2007, Martínez de Azagra y Del Río 2012, Pardos et al. 2015

Crous 2016

Reque y Bravo 1993, Peñuelas et al. 1996, Jiménez et al. 2013

Peñuelas et al. 1996, Cañellas et al. 2008, Serrada et al. 2005

Peñuelas et al. 1996, Serrada et al. 2005, Rey et al. 2005

Reque y Bravo 1993, Peñuelas et al. 1996, Jiménez et al. 2013

Rey et al. 2005

Daños mecánicos: por golpes, por eliminación de parte de la planta, por aviveramiento descuidado, por plantación defectuosa

Sombreado

Temperaturas extremas (altas o bajas) en el suelo $\mathrm{y} / \mathrm{o}$ en el aire

Herbivoría (ramoneo)

Protectores

Exceso de insolación (en especies de sombra, especies umbrófilas)

Sombreado

$\mathrm{pH}$ muy desajustado; algunos elementos pueden resultar tóxicos (caso del aluminio, del boro, o del Enmiendas cobre)

Déficit (en muy contadas ocasiones: exceso) de Fertilización nutrientes

Falta de oxígeno en el suelo por encharcamientos prolongados (situación improbable en zona árida)
Rey et al. 2005

Reque y Bravo 1993, Peñuelas et al. 1996, Jiménez et al. 2013

Ceacero et al. 2014, Reque y Martín 2015

Rey et al. 2005

Puértolas et al. 2003, Cañellas et al. 2008 


\section{El riego de brinzales}

\subsection{Tipos de riego forestal}

El riego de repoblaciones es una práctica antigua y los riegos de arbolado no son ajenos al sector forestal. Tanto en jardinería como en viveros, así como en choperas, en plantaciones truferas, en plantaciones de nogales o en la fruticultura, son frecuentes por ser necesarios o por resultar rentables. Se usa desde el riego a manta hasta riegos por aspersión, microaspersión o goteo.

El uso de la irrigación en las plantaciones forestales de muchas zonas áridas y semiáridas comenzó a practicarse a partir de 1860, en el marco de lo que Armitage (1985) denominó «selvicultura irrigada», cuyo objetivo es maximizar la producción de biomasa. Las técnicas de riego empleadas son mayoritariamente importadas de la tecnología de cultivo agrícola. En una geografía donde el agua es escasa, la finalidad perseguida por este tipo de riegos es discutible y en pocas circunstancias factible social y económicamente. Además, las tecnologías de riego tradicionales no han sido satisfactorias para regar las pequeñas plantas de una repoblación ya que estas se encuentran dispersas en un amplio espacio de terreno y son menos eficientes que los sistemas subterráneos.

El riego para conseguir el establecimiento es una práctica documentada en las repoblaciones forestales en clima árido (Gupta, 1991). Algunos sistemas de micro-riego, como es el caso de riego a través de recipientes porosos, enterrados junto a las raíces de las plantas, son antiguos. Tilló (2006) refiere que los fenicios enterraban vasijas de arcilla porosa al pie de los olivos y que las rellenaban con agua a intervalos regulares. También los romanos parecen haber conocido y difundido este sistema de irrigación (UNEP, 1997). Ello puede explicar el hecho de que en la cultura rural mediterránea el sistema sea bien conocido.

Estos sistemas específicos de microrriego difieren de los practicados en agricultura por dos motivos principales: su objetivo y su necesidad de ahorrar agua. Los riegos de brinzales no persiguen una alta producción sino el establecimiento de una vegetación leñosa: árboles y/o arbustos bien adaptados al lugar que -una vez arraigados- prosperen y se desarrollen de manera autónoma, restaurando el ecosistema y/o mejorando el paisaje. Además, y por estar pensados para zonas áridas, la eficiencia en la aplicación del agua resulta crucial.

En España se ha utilizado en plantaciones en condiciones de fuertes limitaciones hídricas; son las denominadas repoblaciones con biberón (Serrada et al., 2005). En la histórica repoblación forestal de Sierra Espuña se aplicaron pequeños riegos de establecimiento y de socorro a los pinos carrascos con ayuda de cántaros, como relata Codorníu (1898). En la xero-jardinería forestal extensiva, en Valladolid, Martínez de Azagra y del Río (2012) documentaron la utilización de botos enterrados en la repoblación del «Cerro San Cristóbal». 
Estos sistemas persiguen el ahorro en la dotación de agua y la eficiencia en su aplicación. Las técnicas de riegos con sistemas no convencionales, algunas ya contrastadas y otras en fase de experimentación, están teniendo una incipiente difusión mundial (Martínez de Azagra y Del Río, 2012) principalmente en las tierras secas.

\subsection{Los riegos de establecimiento de brinzales}

La utilización de los micro-riegos de mantenimiento y supervivencia (Bainbridge 2007; Martínez de Azagra y Del Río, 2012) es una alternativa interesante para evitar marras por estrés hídrico. En tierras secas, la estrategia forestal clásica de sistematizar el terreno mediante preparación del terreno puede no ser suficiente si el riesgo de que las precipitaciones sean débiles, es elevado. En tales situaciones, la opción del riego debe ser analizada como posible alternativa ventajosa frente a la necesidad de tener que reponer marras de forma reiterada, práctica con resultados caros e inciertos por la variabilidad de las precipitaciones.

El campo de aplicación del riego forestal de establecimiento está indicado en áreas críticas y estaciones forestales difíciles y en años en los que la pluviometría escasa pueda provocar el fracaso de la repoblación (Serrada et al., 2005). Su uso también puede ser aconsejable en entornos climatológicamente menos severos: por ejemplo, cuando se utilice planta de elevado coste, como es el caso de los brinzales micorrizados con hongos valiosos (Oria de Rueda, 2007; Martínez et al., 2011), o cuando la tolerancia admisible de marras sea estricta, como ocurre en la protección de ciertas infraestructuras o en el control de algunos procesos erosivos severos de forma urgente mediante cubierta vegetal (Serrada et al., 2005), proyectos con tolerancias de fallo estrictas y reguladas, o con periodos breves de tiempo para asegurar el establecimiento.

En climas mediterráneos secos los riegos son especialmente aconsejables durante el primer verano (Bocio et al., 2002; Maestre et al., 2003; Rey y Camacho, 2004; Vallejo et al., 2005; Cortina et al., 2011), periodo en el que se concentran las marras si el sistema radical no está suficientemente desarrollado (Stone, 1955; Padilla y Puignaire, 2007; León et al., 2011). La irrigación de los brinzales revierte esta situación al incrementar la profundidad de las raíces y la proporción de la parte subterránea frente a la aérea, evidencia que ha sido hallada en pinos y robles por varios autores (p. ej. Torreano y Morris, 1998).

El método más utilizado para calcular las necesidades hídricas en el establecimiento de brinzales (Allen et al., 1998; Rosa et al., 2012a; Rosa et al., 2012b), en condiciones de estrés hídrico y cobertura reducida (situaciones que son habituales en tierras secas) recurre a la estimación de la evapotranspiración del cultivo. Sin embargo, para las especies utilizadas con mayor frecuencia en las repoblaciones forestales, aún no está determinado con exactitud el valor de los coeficientes de cultivo. Los valores tabulados para olivos, almendros y árboles frutales en tierras secas, son una primera referencia que puede ser empleada en los proyectos de repoblación. En la actualidad, diversos estudios (p. ej. Pakparvar et al., 2014; Pôças et al., 2014) calibran estos valores 
con la ayuda de la teledetección, pudiendo extenderse esta metodología al ámbito forestal.

\subsubsection{El sobrecoste del riego}

En las recomendaciones prácticas, el factor económico tiene un peso elevado que condiciona su utilización y se debe tener en cuenta porque algunos sistemas alcanzan precios unitarios elevados, incluso superiores a veinte veces el de la propia planta que han de irrigar (Del Río et al., 2013). Esto motiva que el efecto en el rendimiento de la plantación sea alto, no sólo por la elevada influencia en los costes, beneficios y tasa de éxito de la plantación, sino también porque se realizan en los primeros años del ciclo de vida de la inversión (Mangaoang, 2002; Hepburn y Koundouri, 2007). Por esta causa, la influencia sobre la rentabilidad del proyecto es muy sensible a la tasa de descuento considerada, especialmente en proyectos forestales a medio y largo plazo que habitualmente tienen tiempos de retorno de la inversión superiores a los 30 o 40 años (Lexer et al., 2005; Hawkins et al., 2006).

A pesar de su eficacia para evitar las marras por estrés hídrico y de que se practique con sistemas no convencionales, el riego introduce un sobrecoste en los proyectos de plantación de árboles y arbustos lo que supone una incertidumbre en la elección de esta alternativa por parte de los consumidores. Los productores de tecnología desconocen el tamaño del mercado lo que limita sus inversiones y dificulta la fijación del precio.

La cuestión que se plantea a la economía es ¿si los buenos resultados selvícolas del riego compensan el sobrecoste que supone su utilización? Es decir, se pide a la economía evaluar si la inversión mejora la relación coste-beneficio de la plantación (Oliet y Jacobs, 2012). Aunque la mejora de los ratios inversión/beneficio parece claramente establecida en la selvicultura de especies forestales con alto beneficios económicos (Rey y Camacho, 2004; Yin y Sedjo, 2001; Siry et al., 2004; Allen et al., 2005; Cubbage et al., 2007; Jones et al., 2010), la rentabilidad en plantaciones de brinzales que carecen de estos beneficios es más dudosa, especialmente si no se consideran los incrementos de crecimiento y producción proporcionados por los cuidados culturales (Boston y Bettinger, 2001) o se incorporan los beneficios no monetarios (Robbins y Daniels, 2012; Duke et al. 2013; Hsu y Loomis, 2002).

\subsubsection{La economía circular}

El riego de brinzales en tierras secas utiliza un bien escaso: el agua. El consumo agua en una región árida tiene más impacto ambiental y económico que el consumo en una zona con abundantes recursos hídricos (Ridoutt y Huang, 2012). Este hecho despierta dudas sobre la conveniencia y posibilidad de destinar agua para el establecimiento de las plantas en las repoblaciones cuando otros usos la están demandando. 
Despejar esta incertidumbre no es una tarea sencilla. La presión sobre los recursos hídricos ha conducido a un reconocimiento de la sociedad sobre la importancia del uso sostenible del agua (Launiainen et al., 2014) y a una progresiva integración de indicadores en la gestión del agua (Chapagain y Tickner, 2012). Entre estos indicadores los de mayor relevancia son el agua virtual del producto (Allan, 2002) y la huella hídrica del consumo (Hoekstra y Hung, 2002). Ambos están basados en el concepto económico de ventaja competitiva (Jia et al., 2012), son una herramienta que tiene un interés corporativo, ambiental y económico y crean un lenguaje común en el que reflejar la apropiación, eficiencia, sostenibilidad e impacto en el uso y consumo que la sociedad hace del agua en gran variedad de procesos y productos.

A partir de los indicadores citados se puede conocer cuáles son las unidades obra que requieren menor cantidad de agua en todo el proceso de repoblación. Verificar este principio de reducción de insumos de la economía circular es uno de los requisitos necesarios para lograr la sostenibilidad (Geissdoerfer et al., 2017). A pesar del perfeccionamiento del cálculo de la huella hídrica en los bosques (Launiainen et al., 2014), este marco de análisis en selvicultura y en concreto en las repoblaciones forestales, todavía no ha recibido suficiente atención.

El interrogante abierto es conocer el resultado del balance entre el agua virtual contenida en un brinzal que se desplaza a la repoblación y que se tiene que reponer (en caso de que no sobreviva por causas del estrés hídrico) y la huella hídrica del riego necesario para su establecimiento. Esta cuestión no es trivial; los brinzales importan agua virtual y la importación de agua virtual es la forma más directa de compensar la ausencia de agua (Liu et al., 2009). A su vez, considerar aisladamente un único factor productivo como es el agua, sin considerar la globalidad de factores empleados, como pueden ser el suelo o la energía, conlleva, en ocasiones, recomendaciones contradictorias como demuestran Jia et al. (2016).

\section{Sistemas de decisión aplicados a la selección de cuidados culturales en las plantaciones de brinzales}

\subsection{La herencia de los sistemas de decisión de la gestión forestal}

Las revisiones recientes (Gardiner y Quine, 2000; Kangas y Kangas, 2005; Johnson et al., 2007; Reynolds et al., 2008; Díaz-Balteiro y Romero, 2008; Hanewinkel, 2009; Pasalodos et al., 2013; Segura et al., 2014; Bare y Weintraub, 2015) los manuales (Kangas et al., 2008) y el análisis de casos (Segura et al., 2014; Borges et al., 2014; Nobre et al., 2016) de los sistemas de ayuda a la toma de decisiones (DSS) en la gestión forestal, muestran como las distintas aproximaciones planteadas han contribuido a enriquecer el conocimiento de la economía del establecimiento de los brinzales y con ella, a la selección de los cuidados culturales (CC) (Hyde, 1980; Busby et al., 1998; Mason, 1995; Mangaoang, 2002; Hepburn y Koundouri, 2007; Boston y Bettinger, 2001; Vallejo et al., 2012; Hawkins et al., 2006). 
Entre las distintas aproximaciones se pueden distinguir dos grandes grupos: las que se han centrado en buscar soluciones eficaces del efecto a largo plazo de los CC sobre la producción (p. ej. Snowdon y Waring 1984; Mason et al., 1991; Cortini et al., 2010; Knoke et al., 2017) y las que se han dirigido a evaluar los efectos a corto plazo del CC sobre la supervivencia y el crecimiento (Macmillan et al., 1998; Pywell et al., 2007; Ahtikoski et al., 2010; Wainger et al., 2010). Ambas utilizan métodos que incorporan alguna medida del éxito del CC en función del grado de conocimiento sobre el beneficio. Si el beneficio es conocido acuden al análisis coste-beneficio (CBA) (Hanley y Splash, 1993; Hawkins et al., 2006; Birch et al., 2010). En ausencia de ellos, si se dispone de un índice de eficacia o desempeño, recurren a un análisis coste-eficacia (CEA) (Macmillan et al., 1998; Pywell et al., 2007; Ahtikoski et al., 2010; Wainger et al., 2010; Nijnik et al., 2013). En el supuesto de no disponer de ninguna de las fuentes de información anteriores, es habitual que se estime el beneficio a través del coste que evita (ACM) (Beecher, 1996; Donovan y Brown, 2008; Snider et al., 2006).

La inclusión del beneficio no fue la solución definitiva al problema de la toma de decisiones sobre los CC en las repoblaciones. Prueba de ello es que estas aproximaciones se han ido adaptando para conseguir reconciliar la optimización de coste y beneficio mediante métodos multicriterio (Mendoza, 1986; Romero et al., 1998; Espelta et al., 2003; Lexer et al., 2005; Gilliams et al., 2005), la inclusión de modelos de supervivencia de los brinzales (Calama et al., 2015), la evaluación de la incertidumbre en los retornos económicos mediante opciones reales (Thorsen y Malchov-Moller, 2003) o la incorporación del riesgo (Pasalodos et al., 2013; Mechler, 2016).

Estas colecciones de metodologías conviven en la actualidad porque se ha tenido que abordar la sucesiva incorporación de finalidades, condicionantes (Vacik y Lexer, 2013) y pluralidad de problemas en la gestión forestal (Nobre et al., 2016; Masiero et al., 2015) a la vez que se intenta satisfacer los requerimientos de múltiples usuarios mediante los DSS (Tabla 3). 
Tabla 3. Principales finalidades de los DSS de selección de cuidados culturales según destinatario

\begin{tabular}{|c|c|}
\hline Finalidad & Autor \\
\hline \multicolumn{2}{|l|}{ Gestores, proyectistas y propietarios } \\
\hline Guiar la elección del cuidado cultural & $\begin{array}{l}\text { Catchpoole y Nester 2004, Löf } \\
\text { et al. 2012, Dey et al. 2008; } \\
\text { Rodrigues et al. 2009, Espelta } \\
\text { et al. } 2003\end{array}$ \\
\hline Determinar la eficiencia de las diferentes prácticas & Cortina et al. 2011 \\
\hline Evaluar la aplicación simultánea de varios cuidados culturales & Jones et al. 2010 \\
\hline Priorizar cuidados culturales & Haddock et al. 2007 \\
\hline Evaluar un cambio de cultivo agrícola a forestal & Ovando et al. 2010 \\
\hline \multicolumn{2}{|l|}{ Investigadores } \\
\hline $\begin{array}{l}\text { Determinar la posibilidad de trasladar de forma realista, a la práctica, } \\
\text { los resultados experimentales obtenidos en parcelas de ensayo } \\
\text { debido a que los costes a escala proyecto pueden hacer inabordable } \\
\text { la trasferencia tecnológica de los resultados de la investigación }\end{array}$ & $\begin{array}{l}\text { Miller y Hobbs 2007, Cortina et } \\
\text { al. 2011, Suding } 2011\end{array}$ \\
\hline \multicolumn{2}{|l|}{ Políticos y ciudadanos } \\
\hline $\begin{array}{l}\text { Proporcionar un marco financiero para la evaluación de las } \\
\text { consecuencias económicas de las políticas forestales y las normativas. }\end{array}$ & Hawkins et al. 2006 \\
\hline $\begin{array}{l}\text { Mejorar la disponibilidad y el coste de los recursos financieros que } \\
\text { necesita el sector forestal gracias a una mejor compresión de cómo } \\
\text { se comportan las inversiones forestales }\end{array}$ & Liley 2000 \\
\hline \multicolumn{2}{|l|}{ Fabricantes } \\
\hline $\begin{array}{l}\text { Orientar la fijación del precio a los industriales que desarrollan } \\
\text { patentes e invenciones relacionadas con los cuidado culturales }\end{array}$ & Del Río et al. 2018 \\
\hline
\end{tabular}

La pluralidad de intereses y usuarios ha propiciado que los DSS centren sus esfuerzos en resolver los objetivos de planificación a largo plazo (Borges et al., 2014; Biber et al., 2015; Grêt-Regamey et al., 2017). Si se soluciona el largo plazo también se solucionará el corto plazo. Este supuesto ha alejado el foco de atención en la resolución de los problemas específicos relacionados con el diseño de los proyectos de repoblación, y en concreto, con la selección de CC. Algunos datos disponibles permiten ilustrar esta tendencia: sólo el 4,3\% de los métodos multicriterio (Díaz-Balteiro y Romero, 2008) o el $24,2 \%$ de los tipos de problemas inventariados en FORSYS (2012) se ocupan del corto plazo (Borges et al., 2014; Segura et al., 2014).

De acuerdo con esta orientación temporal, la dimensión estratégica y táctica es la más utilizada en los DSS (Borges et al., 2014). En este enfoque, el desarrollo de los DSS emplea modelos de selección de alternativas que incorpora el efecto a corto plazo mediante indicadores de éxito de la plantación cercanos a la fase de establecimiento de los brinzales, como son la supervivencia o el crecimiento inicial. La supervivencia lograda por las técnicas de establecimiento es una medida técnica habitual del éxito inicial de la plantación (Ivetić, 2015). La información de supervivencia y crecimiento inicial se incorpora en modelos de crecimiento que finalmente ofrecen como resultado los bienes y/o servicios que produce la plantación (Djanibekov y Khamzina, 2016; Pasalodos et al., 2016). En estos modelos, la elección económica de las actuaciones iniciales involucradas en los proyectos de repoblación, está subordinada al criterio de optimización de la producción de bienes y/o servicios de la plantación (Ahtikoski et al., 2010). La medida del éxito inicial de la plantación se encapsula en la calidad, es decir, en 
la adecuación de los trabajos a los objetivos de la plantación (Serrada et al., 2005) o en otros indicadores más relacionados con el impacto o efecto sobre la sociedad como medida del resultado de la plantación (Löf et al., 2012; Le et al., 2014, Jacobs et al., 2015) o en indicadores agregados de sostenibilidad (Díaz-Balteiro et al., 2017).

La aplicación de estas metodologías a la selección de los DSS ha proporcionado recomendaciones sobre el campo de aplicación más adecuado de los CC que han concluido que son actuaciones reservadas a la selvicultura intensiva (Gan et al., 1998), fuera de cuyo ámbito su utilización no está justificada económicamente porque los costes no compensan los beneficios que proporcionan (Boston y Bettinger, 2001). Estas aportaciones han consolidado la idea, muy arraigada entre los gestores y propietarios forestales, de que las inversiones y los costes en las medidas de establecimiento deben ser moderadas (Hawkins et al., 2006) y que existe un límite o esfuerzo económico máximo que podemos destinar a financiar estas actuaciones (Hyde, 1980).

\subsection{La crisis actual en la elección de cuidados culturales basados en los sistemas de toma decisiones procedentes de la gestión forestal}

La selección de cuidados culturales mediante el enfoque de la gestión forestal es compleja y conviven objetivos muy dispares: los del corto plazo de los CC y el largo plazo de la plantación. Desde la visión a largo plazo de las inversiones forestales se han empleado criterios de decisión basados en el análisis de coste beneficio (Hanley y Splash, 1993; Hawkins et al., 2006; Birch et al., 2010) que han buscado seleccionar los CC desde los objetivos de minimización de los costes o maximización de los beneficios.

La minimización de costes se plantea cómo obtener la densidad objetivo de la masa con el coste más bajo (Walker et al., 1985; Dey et al., 2008). En la selección de proyectos se ha trabajado según los costes y beneficios considerados con el concepto de conservación rentable (Duke et al., 2013) y soluciones eficientes económicamente.

La maximización de beneficios formula la siguiente cuestión: ¿cuál es el coste selvícola máximo que se puede invertir? Bajo este criterio se determina el nivel de intervención selvícola (Navarro y Martínez, 1997), intensidad de regeneración (Zhou, 1999), esfuerzo selvícola máximo (Hyde, 1980), densidad mínima (Zhou, 1999) y número de años para conseguir el establecimiento (Ahtikoski et al., 2010).

A la visión largoplacista predominante en la gestión forestal se ha opuesto otra más cortoplacista que intenta solucionar el encapsulamiento de las operaciones iniciales del establecimiento en la globalidad del proyecto y la invisibilidad de su eficacia. Para ello, recurren al análisis de coste-eficacia (Macmillan et al., 1998; Pywell et al., 2007; Ahtikoski et al., 2010; Wainger et al., 2010). La decisión más rentable no es la más eficaz para conseguir el establecimiento, por eso basan la selección en indicadores costeeficacia que permita elegir aquellas actuaciones con mejores resultados y menor coste, con independencia de su repercusión en la viabilidad económica de la inversión. Bajo esta misma perspectiva se han utilizado aproximaciones de costes evitados (Beecher, 
1996; Donovan y Brown, 2008; Snider et al., 2006) y multicriterio (Díaz-Balteiro y Romero, 2008; Wilson et al., 2011).

A esta dualidad de enfoques se añaden otros factores que están contribuyendo a reconsiderar el enfoque actual de los sistemas de apoyo a la toma de decisiones (DSS) aplicados a la selección de cuidados culturales (CC).

Las evidencias sobre el terreno muestran que las tecnologías o técnicas más rentables no siempre garantizan el éxito de la plantación. Los motivos son variados: i) pueden producirse marras que acarreen sobrecostes que obliguen a los propietarios a realizar una plantación suplementaria y alarguen los períodos de tiempo para conseguir la densidad objetivo (Ahtikoski et al., 2010; Lof et al., 2012), ii) se incumplan requisitos legales, financieros, técnicos o temporales que potencialmente puedan hacer fracasar la plantación (Sullivan y Amacher, 2013); y iii) en ocasiones los CC tienen costes, beneficios y eficacia muy similares entre sí.

Los resultados de los ensayos de campo están mostrando que la inversión en CC incrementa la supervivencia (Kankaanhuhta y Saksa, 2013) y cómo la utilización individual o combinada de ellos (Granhus y Fjeld, 2008) permite un cumplimiento más temprano y menos costoso de los requisitos de la plantación (Hawkins et al., 2006). Estos resultados han contribuido a despertar el interés por los CC y considerarlos relevantes en las estaciones donde es necesario asegurar la supervivencia, sitios difíciles en los que existen severas limitaciones para el establecimiento de las plantas (Vallejo et al., 2012; Busby et al., 1998; Dubois et al., 2001) o donde existe una baja tolerancia al fallo. También ha contribuido a consolidar este interés la preocupación por la alta mortalidad de los brinzales después de la plantación que propician los episodios de baja precipitación, durante la estación de crecimiento, previstos por los escenarios de cambio climático (Ivetić y Devetaković, 2016).

Los DSS actuales ofrecen decisiones binarias que no permiten distinguir situaciones que recomienden el CC, de aquellas en las que una respuesta no es necesaria, ya sea porque el riesgo es demasiado pequeño o porque es demasiado grande. Se busca evitar la sobre-reacción o la falta de reacción del decisor (Gardiner y Quine, 2000).

La utilización de los DSS y las prescripciones que ofrecen pueden ser mejoradas añadiendo el conocimiento práctico de la gestión (Perks et al., 2007) y sus variables de trabajo habituales.

\subsection{La necesidad de un marco propio para la selección de cuidados culturales}

Para mejorar los sistemas de apoyo a la toma de decisiones (DSS) es necesario profundizar en la economía del establecimiento de las plantaciones, que para algunos autores (Löf et al., 2012; Ahtikoski et al., 2010) está insuficientemente desarrollada. En este contexto se está comenzando a retomar la economía del establecimiento de masas (Hyytiäinen et al., 2006; Ahtikoski et al., 2010; Lof et al., 2012; Hawkins et al., 2006), habitualmente mediante evaluaciones específicas basadas en datos experimentales, más que en desarrollos teóricos (Hobbs y Harris, 2001; Matthews et al., 2009; Kettenring y 
Adams, 2011; Löf et al., 2012; Robins y Daniel, 2012). La preparación del terreno es la actuación del establecimiento que más atención ha recibido (Hawkins et al., 2006; Löf et al., 2012), y progresivamente se están incorporando conceptos habituales de estudio de la microoeconomía, como el grado de aversión al riesgo del decisor (Lien et al., 2007).

En el desarrollo de la economía del establecimiento se están encontrando con varias dificultades. El principal problema que detectan es el encapsulamiento de las operaciones iniciales en la globalidad del proyecto. En el enfoque a largo plazo los CC son un medio que ayuda a adquirir una condición adecuada para que la plantación produzca los bienes y servicios para los que fue diseñada (Wortley et al., 2013). La solución que se plantea es individualizar la operación concreta que se quiere analizar. En esta línea de trabajo Ahtikoski et al. (2010) proponen el concepto de «cadena de establecimiento» que definen como el conjunto de operaciones técnicas que abarcan desde la preparación del terreno, tratamientos previos y plantación, hasta los cuidados culturales.

El siguiente problema es que el tratamiento habitual del coste unitario favorece la invisibilidad de los parámetros que definen una repoblación dentro de la cadena de operaciones necesarias para su establecimiento (Hyytiäinen et al., 2006), como por ejemplo la densidad (Hyytiäinen et al., 2006) o la tolerancia de fallos (Zhou et al., 1999) lo que dificulta trasladar los resultados experimentales a otras localizaciones geográficas (Gardiner y Quine, 2000; Palmer et al., 2007). Cualquier variación de diseño de la plantación o de la estación obliga a recalcular el proyecto y el estudio previo no se puede aplicar de forma directa.

Tradicionalmente el establecimiento de plantas se divide en paquetes de trabajo valorados económicamente con un precio de mercado que recibe el nombre de unidad de obra. La unidad de obra incluye los materiales, la maquinaria y la mano de obra necesarios para realizar una actuación concreta. Los costes de establecimiento incluyen las unidades de obra necesarias para asegurar la instalación y puesta en funcionamiento de los cuidados culturales. Las unidades de obra están particularizadas al contexto geográfico y social y se expresan en un precio unitario. Existen otros costes que están involucrados en el establecimiento de los brinzales y que habitualmente no se incluyen en los análisis (Robbins y Daniels, 2012): los costes ocultos (Zentner et al., 2003), los costes de oportunidad (Kniivilä y Saastamoinen, 2002; Wilson et al., 2011) y los costes inducidos (Ovando et al., 2010).

Determinar el beneficio de los CC es complejo ya que hay que englobar distintos objetivos, los cuales no son mutuamente excluyentes (Stanturf et al., 2014) y además porque los cuidados culturales pueden producir interacciones sobre los beneficios (Hawkins et al., 2006; Dostálek et al., 2007; Uotiola et al., 2010; Del Río et al., 2013). En ocasiones propician la anticipación y/o el incremento de la producción, hecho que repercute en un adelanto e incremento de los beneficios (Johansson et al., 2013). En otros casos puede disminuir simultáneamente otro tipo de beneficios (Gan et al., 1998) o facilitar las actuaciones posteriores, lo que supone una disminución de los costes 
selvícolas post-establecimiento; en estos casos el beneficio es un coste evitado (Pinjuv et al., 2001).

La revisión de métodos económicos enseña que la selección de alternativas de CC basadas en costes evitados, o coste y eficacia, tiene diversas limitaciones (Beecher, 1996; Wainger et al., 2010) entre las que destaca la necesidad de incorporar indicadores de evaluación económica que tengan en cuenta el posible efecto al largo plazo de los CC (Uotila et al., 2010).

La evaluación económica precisa de criterios de decisión. Los métodos de la gestión forestal utilizados en la selección de CC se basan en hallar la restricción presupuestaria con algún objetivo de maximización o minimización. La decisión que ofrecen es binaria: si o no. Sin embargo, es el mercado el que fija los precios por lo que el problema de decisión puede reformularse mediante variables de decisión que proporcionen al usuario un umbral de decisión no necesariamente monetario (Stern et al., 1959; Pedigo, 1986; Bor, 1995; CIMMYT, 1988; Martin et al., 2009). El reto es ahora encontrar la variable o variables de decisión ligadas de alguna manera al objetivo del $\mathrm{CC}$, al diseño de la plantación, a los requerimientos normativos y al riesgo de cada estación, especialmente por los efectos de los escenarios de cambio climático sobre las marras (Yousefpour et al., 2012). La variable de decisión continúa siendo un problema abierto. La mortalidad o su complementario, la supervivencia de los brinzales, es el más utilizado pero otros autores inspirados por la visión a largo plazo proponen otras medidas basadas en variables que miden la biomasa, el crecimiento o la dominancia de los brinzales (Johnson et al., 2002; Dey et al., 2008). Estos índices han tenido menor aceptación por centrarse en un momento posterior a la fase de establecimiento.

El tipo de enfoque determinista o estocástico es otra de las cuestiones a abordar. La probabilidad de éxito del establecimiento (Wainger et al., 2010) y la incertidumbre de las variables son herramientas útiles para estimar las pérdidas en las que se incurre por no utilizar los DSS (Liley, 2000; Lien et al., 2007). Conocer esta incertidumbre, no solo es interesante para estimar el valor de información, también es útil para evitar adoptar decisiones subóptimas (Pukkala, 1998; Thorsen y Helles, 1998) que conlleven pérdidas en resultados económicos (Burkhart et al., 1978; Pukkala, 1998; Eid, 2000; Duvemo y Lämås, 2006; Mechler, 2016). Por estos motivos es conveniente incluir algún indicador que permita evaluar el riesgo de las amenazas naturales que intenta evitar la aplicación de los CC (Kull, 2013) como realizan otros DSS en otras áreas de la gestión forestal (Pasalodos et al., 2013).

Los cuidados culturales compiten con la reposición sucesiva de plantas hasta que se alcanza la densidad objetivo de la plantación. La reposición es la técnica habitual en caso de no aplicarse CC, por lo que cualquier alternativa técnica que se quiera introducir debe comparase con el statu quo. Sin embargo, no se han propuesto ecuaciones para describir, desde el punto de vista económico, cómo se comporta la reposición sucesiva de marras en las plantaciones de brinzales. 
Los destinatarios de los modelos no los usan en profundidad (Calama et al., 2017b). La mejora de la percepción de utilidad de los usuarios es uno de los aspectos a trabajar en los DSS (Faias et al., 2012). El diseño de DSS versátiles, con un amplio campo de aplicación, que a su vez sean fáciles de utilizar, es un requisito demandado por los usuarios no siempre fácil de alcanzar (Calama et al., 2017b). Menos hipótesis requieren de más ecuaciones y variables. Este enfoque alarga la vida útil del modelo, su plasticidad para ser usado en múltiples situaciones y está abierto a futuros requerimientos de los agentes implicados (Gordon et al., 2014; Muys et al., 2010), pero complica su uso.

Además, se detecta la existencia de un amplio espectro de las partes interesadas en los modelos económicos que abarca a gestores y propietarios (aparecen citados en el $60 \%$ de los artículos), investigadores (20\%), políticos y ciudadanos $(13 \%)$ y fabricantes de tecnologías de cuidados culturales (7\%). La posibilidad de simular el comportamiento y requerimientos de los distintos agentes decisores (Rinaldi et al., 2015) es otro de los retos para los DSS. En este sentido la posición del observador es un tema crucial para diseñar la evaluación económica. Se ha observado la existencia de varios agentes decisores. Cada uno de ellos utiliza un criterio distinto de decisión acorde a sus intereses particulares. Algunos de estos criterios provienen de la teoría económica, como es el caso de la maximización de beneficios, el valor en riesgo, el punto de Kaldor-Hicks, o la minimización de los costes. Otros criterios son el resultado de estudios empíricos cuyo valor se ha hallado para la adopción de nuevas tecnologías o de mejoras tecnológicas por parte de los agricultores (CIMMYT, 1988). También se ha estimado cuál es el criterio utilizado habitualmente por los gestores de fondos públicos (Mechler et al., 2016). Cada uno de estos criterios tiene asociada una tasa marginal y para cada valor concreto de marras, puede hallarse el riesgo que asumen. En estudios que consideran el largo plazo (Brunette et al., 2017) se ha detectado experimentalmente que la componente geográfica es relevante. El aumento de la exposición al riesgo influye positivamente en la aversión al riesgo del decisor y repercute en su toma de decisiones.

El efecto «caja negra» de los modelos es otra de las barreras que impide cumplir con las expectativas de los usuarios; para superarla, los DSS deben describir la metodología incluida en cada modelo (Pastorella et al., 2016) y definir de forma explícita las hipótesis y supuestos auxiliares en las que se basan. De esta manera, se puede conocer el campo de aplicación actual del modelo y determinar la posibilidad de adaptarlos a futuras demandas de la sociedad, al igual que se ha hecho de forma prolija con los DSS basados en el turno óptimo (Newman, 1988; Kula, 1988; Díaz-Balteiro, 1998).

\section{Las incertidumbres en la toma de decisiones sobre cuidados culturales}

\subsection{La necesidad de información: bases de datos sobre marras}

El análisis espacial y temporal de las repoblaciones realizadas y el seguimiento de la actividad repobladora requiere la creación de bases de datos (Pemán, 2015). Las actividades de seguimiento de las posibles desviaciones del diseño del proyecto, la 
evaluación a corto plazo del establecimiento de la plantación, la evaluación a medio plazo de la consecución de los objetivos de la plantación, y a largo plazo de la evolución de la repoblación y su impacto socioeconómico, son actividades que generan datos. El sistema actual basado en estadísticas no recoge y sistematiza esos conjuntos de datos y es insuficiente para la puesta en valor del conocimiento tácito que encierra la labor repobladora ejecutada; conocimiento tácito que tiene gran influencia en el desarrollo económico (Hausann e Hidalgo, 2014).

En el marco de los servicios de los ecosistemas (MA, 2003) la información sobre las repoblaciones realizadas proporciona un servicio cultural en forma de datos espaciales, es un recurso científico que puede generar conocimiento explícito de la labor desarrollada por la ingeniería y ser exportado a geografías con menos experiencia repobladora y permite determinar la calidad de la repoblación (Serrada et al., 2005) además de obtener conclusiones para mejorar los proyectos (Pemán, 2015) y obtener códigos de buenas prácticas (Wortley et al., 2013).

Solucionar esta carencia de bases de datos armonizados e interoperables, es un ejercicio de consenso y compromiso que en el ámbito de los datos espaciales suele requerir esfuerzos supranacionales para su integración en infraestructuras de datos espaciales. Estos procesos se pueden ver favorecidos por la elaboración de información sobre el valor económico de los datos, no sin antes modificar la clasificación de valor de no uso asociado al conocimiento científico y técnico sobre los ecosistemas (Hein et al., 2006), habitualmente cuantificado por métodos contingentes (Holmes et al., 2004) a otros marcos y métodos de valoración más cercanos a los precios de mercado.

Desde el punto de vista técnico, el diseño de las bases de datos tiene un doble condicionante. En primer lugar, debe permitir añadir la información sobre las nuevas plantaciones y, en segundo lugar, debe permitir incorporar los datos de la experiencia acumulada en las repoblaciones ya realizadas. Este último condicionante es especialmente relevante en países con larga tradición repobladora.

\subsection{La incertidumbre global sobre la utilización de la tecnología del riego en el establecimiento de brinzales en los proyectos de repoblación}

La revisión crítica muestra la incertidumbre en la gestión de las marras cuando las tecnologías o técnicas más rentables no garantizan el éxito del establecimiento. En estas situaciones se originan sobrecostes porque obliga a los propietarios a realizar una plantación suplementaria, además de implicar períodos prolongados de tiempo para lograr el éxito (Ahtikoski et al., 2010). Este retraso puede acarrear el incumplimiento de los requisitos legales, financieros, técnicos, o temporales y potencialmente puede hacer fracasar la plantación (Löf et al., 2012), especialmente cuando las tecnologías compiten entre sí para reducir las marras con costes, beneficios y eficacias muy similares entre sí.

La creación eficiente de una densidad de vegetación durante la restauración forestal es importante (Löf et al., 2012) porque el fracaso conduce a una aplicación ineficiente de los esfuerzos económicos, a la utilización de técnicas inadecuadas y en el 
peor de los casos, al fracaso de la plantación. Además, una misma densidad puede alcanzarse recurriendo a técnicas sustitutivas y/o complementarias, por lo que la actuación técnica no debe generalizar la aplicación de actuaciones sin evaluar su viabilidad y ventaja competitiva en términos económicos. Este planteamiento permite a los gestores evaluar el éxito de las diferentes prácticas de reforestación en términos de inversión y beneficio (Rey et al., 2005) y elegir la tecnología en función de un estudio de costes para optimizar la inversión de los recursos empleados (Rey y Camacho, 2004), que -por lo general- suelen ser bastante limitados en el ámbito forestal.

La economía de las marras cobra especial importancia en este marco puesto que la supervivencia de los brinzales en el establecimiento de la plantación encarece y disminuye el grado de cumplimiento de metas y objetivos. A pesar del reconocimiento de su importancia y efecto, múltiples autores coinciden en señalar que la economía del establecimiento de las masas forestales está insuficientemente desarrollada en la actualidad, tanto para la técnica de preparación del terreno (Löf et al., 2012; Hawkins et al., 2006) como para las tecnologías de los cuidados culturales (Ahtikoski, 2010).

Los riegos de arraigo, mantenimiento inicial y supervivencia resultan muy útiles para evitar marras por estrés hídrico, causa principal de los fracasos en la repoblación forestal de áreas críticas en zonas áridas (Martínez de Azagra y Del Río, 2012). Los riegos son también una práctica justificada, incluso en otros entornos climatológicamente menos severos, cuando el establecimiento tiene que lograr un porcentaje mínimo de éxito, como ocurre en la protección de infraestructuras o el control de procesos erosivos (Serrada et al., 2004).

Sin embargo, la actuación técnica no debe generalizar la utilización del riego en estas situaciones sin disponer de un modelo que evalúe su viabilidad y ventaja competitiva, en términos económicos, frente a otras técnicas sustitutivas, como la tradicional reposición de marras. La evaluación debe estar adaptada a la realidad de las condiciones económicas de cada país y considerar la alternativa de riego más adecuada a cada proyecto de repoblación concreto. Esta toma de decisiones en la fase de diseño de la repoblación exige una valoración técnica a partir de múltiples factores selvícolas, hidráulicos y económicos para determinar cuál es la tecnología más indicada entre los sistemas de riego disponibles.

La revisión crítica del estado del riego en la forestación de tierras áridas y las revisiones de los sistemas de apoyo a la toma de decisiones (Kanowski, 1997; Montalvo et al. 1997; CIMMYT, 1988; Guo et al., 2000; Guo et al., 2001; Lake, 2001; Logar y Van den Bergh, 2001; Kline, 2004; Fairbrother y Turnley, 2005; Waters et al., 2007; Birch et al., 2010; Suding, 2011; Robbins y Daniels, 2012; Wortley et al., 2013) indican las directrices y condicionantes necesarios para el desarrollo de los sistemas de apoyo a la toma de decisiones aplicados a la selección de cuidados culturales en las plantaciones de brinzales: 
i) Los cuidados culturales no solo evitan pérdidas económicas, sino que también pueden proporcionar beneficios. Existe una dificultad para estimar beneficios equiparables entre las diferentes alternativas.

ii) Debe considerar el tipo y la magnitud de variación en los beneficios y costes que provocan los cambios inducidos por las alternativas, tanto en las condiciones del bosque como en las funciones y servicios que proporcionan.

iii) Los criterios para evaluar el éxito de las plantaciones son heterogéneos.

iv) Incluir la densidad lograda en la plantación como medida de la eficacia.

v) Conciliar los horizontes temporales para evaluar la meta concreta e inicial perseguida por los cuidados culturales.

vi) Considerar el presupuesto parcial involucrado en la selección de tratamientos.

vii) Evaluar el contexto económico de los costes de las alternativas, las distintas opciones técnicas de plantación y la variabilidad espacial y temporal de los precios.

viii) Proporcionar prescripciones de gestión cuantitativas, especialmente las referidas al grado de cumplimiento de la meta fijada en el proyecto.

Las citadas directrices y las incertidumbres valoradas en el presente capítulo definen la estructura global y los objetivos de esta tesis doctoral.

\section{Bibliografía}

Abdoun F, Beddiaf M (2002) Cupressus dupreziana A. Camus: répartition, dépérissement et régénération au Tassili n'Ajjer, Sahara central. Comptes Rendus Biologies 325 (5):617-627. doi:10.1016/S16310691(02)01433-6

Ahtikoski A, Alenius V, Mäkitalo K (2010) Scots pine stand establishment with special emphasis on uncertainty and cost-effectiveness, the case of northern Finland. New Forests 40 (1):69-84. doi:10.1007/s11056-009-9183-2

Alarcón J, Garrido A, Juana L (2016) Modernization of irrigation systems in Spain: review and analysis for decision making. International Journal of Water Resources Development 32 (3):442-458. doi:10.1080/07900627.2015.1123142

Alcon F, De Miguel MD, Burton M (2011) Duration analysis of adoption of drip irrigation technology in southeastern Spain. Technological Forecasting and Social Change 78 (6):991-1001. doi:https://doi.org/10.1016/j.techfore.2011.02.001

Alcon F, Tapsuwan S, Brouwer R, De Miguel MD (2014) Adoption of irrigation water policies to guarantee water supply: A choice experiment. Environmental Science and Policy 44:226-236. doi:https://doi.org/10.1016/j.envsci.2014.08.012

Allan JA (2002) The Middle East water question: Hydropolitics and the global economy, vol 2. Ib Tauris, London

Allen HL, Fox TR, Campbell RG (2005) What is ahead for intensive pine plantation silviculture in the south? Southern Journal of Applied Forestry 29 (2):62-69

Allen RG, Pereira LS, Raes D, Smith M (1998) Crop evapotranspiration: Guidelines for computing crop water requirements. FAO Irrigation and Drainage Paper 56:300

Alloza JA, Vallejo VR (1999) Relación entre las características meteorológicas del año de plantación y los resultados de las repoblaciones. Ecología (13):173-187

Armitage F (1985) Irrigation forestry in arid and semi-arid lands. IDRC, Ottawa, Canada 
Badano EI, Pérez D, Vergara CH (2009) Love of Nurse Plants is Not Enough for Restoring Oak Forests in a Seasonally Dry Tropical Environment. Restoration Ecology 17 (5):571-576. doi:10.1111/j.1526100X.2009.00530.x

Bainbridge DA (2007) A guide for desert and dryland restoration: new hope for arid lands. Island Press

Bainbridge DA, Fidelibus M, MacAller R (1995) Techniques for plant establishment in arid ecosystems. Restoration and Management Notes 13 (2):198-202

Bare BB, Weintraub A (2015) Brief history of systems analysis in forest resources. Annals of Operations Research 232 (1):1-10. doi:10.1007/s10479-015-1897-2

Beckage B, Lavine M, Clark JS (2005) Survival of tree seedlings across space and time: estimates from longterm count data. Journal of Ecology 93 (6):1177-1184. doi:10.1111/j.1365-2745.2005.01053.x

Beecher JA (1996) Avoided cost: an essential concept for integrated resource planning. Journal of Contemporary Water Research and Education 104 (1) 28-35

Biber P, Borges J, Moshammer R, Barreiro S, Botequim B, Brodrechtová Y, Brukas V, Chirici G, CorderoDebets R, Corrigan E, Eriksson L, Favero M, Galev E, García J, Hengeveld G, Kavaliauskas M, Marchetti M, Marques S, Mozgeris G, Navrátil R, Nieuwenhuis M, Orazio C, Paligorov I, Pettenella D, Sedmák R, Smreček R, Stanislovaitis A, Tomé M, Trubins R, Tuček J, Vizzarri M, Wallin I, Pretzsch H, Sallnäs O (2015) How Sensitive Are Ecosystem Services in European Forest Landscapes to Silvicultural Treatment? Forests 6 (5):1666-1695

Birch JC, Newton AC, Aquino CA, Cantarello E, Echeverría C, Kitzberger T, Schiappacasse I, Garavito NT (2010) Cost-effectiveness of dryland forest restoration evaluated by spatial analysis of ecosystem services. Proceedings of the National Academy of Sciences 107 (50):21925-21930

Bocio L, De Simón E, Navarro FB, Ripoll MA, Gallego E (2002) Forestación de tierras agrícolas marginales en ambientes mediterráneos. Cuaderno Sociedad Española de las Ciencias Forestales 13:77-84

Bor YJ (1995) Optimal pest management and economic threshold. Agricultural Systems 49 (2):113-133

Borges JG, Nordström EM, García J, Hujala T, Trasobares A (2014) Computer-based tools for supporting forest management. The Experience and the Expertise World-Wide. Department of Forest Resource Management, Swedish University of Agricultural Sciences, Umeå, Sweden

Boston K, Bettinger P (2001) The economic impact of green-up constraints in the southeastern United States. Forest Ecology and Management 145 (3):191-202. doi:10.1016/s0378-1127(00)00417-5

Brunette M, Foncel J, Kéré EN (2017) Attitude Towards Risk and Production Decision: an Empirical Analysis on French Private Forest Owners. Environmental Modeling and Assessment 22 (6):563-576. doi:10.1007/s10666-017-9570-6

Burdett AN (1990) Physiological processes in plantation establishment and the development of specification for forest planting stock. Canadian Journal of Forest Research 20 (4):415-427

Burkhart HE, Stuck RD, Leuschner WA, Reynolds MR (1978) Allocating inventory resources for multipleuse planning. Canadian Journal of Forest Research 8 (1):100-110

Busby RL, Miller JH, Edwards MB (1998) Economics of Site Preparation and Release Treatments Using Herbicides in Central Georgia. Southern Journal of Applied Forestry 22 (3):156-162

Calama R, Manso R, Lucas ME, Espelta JM, Piqué M, Bravo F, del Peso C, Pardos M (2017a) Natural regeneration in Iberian pines: A review of dynamic processes and proposals for management 26 (2). doi:10.5424/fs/2017262-11255

Calama R, Manso R, Gordo J, Montero G, Mutke S, Piqué M, Vázquez-Piqué J, Pardos M (2017b) Which models are needed for Pinus pinea forests? In: Options Méditerranéennes Series A: Mediterranean Seminars, 2017b. INIAV, Instituto Nacional de Investigação Agrária e Veterinária IP; ISA-CEF, Instituto Superior de Agronomia-Centro de Estudos Florestais; CIHEAM-IAMZ, Mediterranean Agronomic Institute of Zaragoza (Spain); FAO-CIHEAM Network on Nuts; UNAC, União da Fl 
Calama R, Puértolas J, Manso R, Pardos M (2015) Defining the optimal regeneration niche for Pinus pinea L. through physiology-based models for seedling survival and carbon assimilation. Trees 29 (6):17611771. doi:10.1007/s00468-015-1257-5

Çalişkan S, Boydak M (2017) Afforestation of arid and semiarid ecosystems in Turkey. Turkish Journal of Agriculture and Forestry 41 (5)

Cañellas I, Montero G, Bachiller A, Finat L (2008) Behaviour of Pinus pinea plants in nursery and field: Trials of plant production, fertilisation and herbicides. Forest Systems 8 (2):335-359. doi:10.5424/619

Castro J, Marañón T, Mendoza I, Pérez IM, Quero JL, Villar R, Zamora R, Zavala MA (2004) Regeneration of tree species and restoration under contrasted Mediterranean habitats: field and glasshouse experiments. International Journal of Ecology and Environmental Sciences 30:187-196

Catchpoole K, Nester MR (2004) A financial calculator: software for evaluating plantation scenarios. Australian forestry 67 (3):191-193

Cavallo E, Ferrari E, Bollani L, Coccia M (2014) Attitudes and behaviour of adopters of technological innovations in agricultural tractors: A case study in Italian agricultural system. Agricultural Systems 130:44-54. doi:10.1016/j.agsy.2014.05.012

Ceacero C, Navarro R, Díaz-Hernández J, Del Campo A (2014) Is tree shelter protection an effective complement to weed competition management in improving the morpho-physiological response of holm oak planted seedlings? (Is tree shelter protection an effective complement to weed competition management in improving the morpho-physiological response of holm oak planted seedlings?). iForest - Biogeosciences and Forestry 7 (5):289-299. doi:10.3832ifor1126-007

Chang SJ (1983) Rotation age, management intensity, and the economic factors of timber production: Do changes in stumpage price, interest rate, regeneration cost, and forest taxation matter? Forest Science 29 (2):267-277

Chapagain AK, Tickner D (2012) Water footprint: Help or hindrance? Water Alternatives 5 (3):563-581

Chunfeng W, Chokkalingam U (2006) National overview. In: Chokkalingam U, Zaichi Z, Chunfeng W, Toma T (eds) Learning Lessons from China's Forest Rehabilitation Efforts: National Level Review and Special Focus on Guangdong Province Center for International Forestry Research (CIFOR), Bogor, Indonesia

Ciccarese L, Mattsson A, Pettenella D (2012) Ecosystem services from forest restoration: thinking ahead. New Forests 43 (5):543-560. doi:10.1007/s11056-012-9350-8

CIMMYT (1988) La formulación de recomendaciones a partir de datos agronómicos: Un manual metodológico de evaluación económica. CIMMYT, Mexico D.F, Mexico

Codorníu R (1898) La Sierra de Espuña y su repoblación forestal. Montes 506:77-79 y Montes 511:213-218

Cortina J, Amat B, Castillo V, Fuentes D, Maestre FT, Padilla FM, Rojo L (2011) The restoration of vegetation cover in the semi-arid Iberian southeast. Journal of Arid Environments 75 (12):1377-1384. doi:10.1016/j.jaridenv.2011.08.003

Cortina J, Bellot J, Vilagrosa A, Caturla R, Maestre F, Rubio E, Martínez J, Bonet A (2004) Restauración en semiárido. In: Vallejo VR, Alloza JA (eds) Avances en el Estudio de la Gestión del Monte Mediterráneo. Fundación Centro de Estudios Ambientales del Mediterráneo, Valencia, pp 345-406

Cortina J, Vallejo VR (1999) Restoration of Mediterranean Ecosystems. In: Farina A (ed) Perspectives in Ecology A glance from the VII International Congress of Ecology. Backhuys Publishers, Leiden, pp $479-490$

Cortini F, Comeau PG, Boateng JO, Bedford L (2010) Yield Implications of Site Preparation Treatments for Lodgepole Pine and White Spruce in Northern British Columbia. Forests 1 (1):25

Crous JW (2016) Use of hydrogels in the planting of industrial wood plantations. Southern Forests: a Journal of Forest Science 79 (3):1-17. doi:10.2989/20702620.2016.1221698 
Cubbage F, Mac Donagh P, Sawinski Júnior J, Rubilar R, Donoso P, Ferreira A, Hoeflich V, Olmos VM, Ferreira G, Balmelli G, Siry J, Báez MN, Alvarez J (2007) Timber investment returns for selected plantations and native forests in South America and the Southern United States. New Forests 33 (3):237-255. doi:10.1007/s11056-006-9025-4

De Simón E, Ripoll M, Fernández E, Navarro FB, Jiménez MN, Gallego E (2006) Eficacia de las microcuencas en la supervivencia del pino carrasco (Pinus halepensis Mill.) y de la encina (Quercus ilex L. subsp. ballota (Desf.) Samp.) en distintos ambientes mediterráneos. Forest Systems 15 (2):218-230

Dean TJ, Chang SJ (2002) Economic rationale for planting less trees in the face of seedling mortality. In: Proceedings of the eleventh biennial southern silvicultural research conference Gen Tech Rep SRS48 Asheville, NC: US Department of Agriculture, Forest Service, Southern Research Station, 2002. pp 149-152

Dearing JW (2009) Applying Diffusion of Innovation Theory to Intervention Development. Research on social work practice 19 (5):503-518. doi:10.1177/1049731509335569

Del Campo AD, Hermoso J, Cabrera AM, Ibañez AJ, Navarro RR (2004) Influencia de la variación local de la estación en la restauración forestal. Cuadernos de la Sociedad Española de Ciencias Forestales 20:79-85

Del Río J, Gómez E, Reque JA, Martínez de Azagra A (2013) Reponer marras o regar brinzales: una disyuntiva a analizar en zona árida. In: In: Martínez C, Lario FJ, Fernández B. (eds) Avances en la restauración de sistemas forestales Técnicas de implantación, Madrid, España., 2013. SECF-AEET, pp 13-18

Del Río J, Reque JA, Martínez De Azagra A (2018) To replant or to irrigate: A silvicultural decision model for afforestation projects. Forest Policy and Economics 93:18-29. doi:https://doi.org/10.1016/j.forpol.2018.05.007

Dey DC, Jacobs D, McNabb K, Miller G, Baldwin V, Foster G (2008) Artificial Regeneration of Major Oak (Quercus) Species in the Eastern United States-A Review of the Literature. Forest Science 54 (1):77106. doi:10.1093/forestscience/54.1.77

Díaz-Balteiro L (1998) Fundamentos económicos del turno forestal óptimo al incorporar diversos bienes y servicios. Revista Española de Estudios Agrosociales y Pesqueros (184):159-182

Díaz-Balteiro L, Alonso R, Martínez M, Pardos M (2017) Selecting the best forest management alternative by aggregating ecosystem services indicators over time: A case study in central Spain. Ecological Indicators 72:322-329. doi:10.1016/j.ecolind.2016.06.025

Díaz-Balteiro L, Romero C (2008) Making forestry decisions with multiple criteria: A review and an assessment. Forest Ecology and Management 255 (8):3222-3241. doi:10.1016/j.foreco.2008.01.038

Djanibekov U, Khamzina A (2016) Stochastic Economic Assessment of Afforestation on Marginal Land in Irrigated Farming System. Environmental and Resource Economics 63 (1):95-117. doi:10.1007/s10640014-9843-3

Donovan GHB, Brown TC (2008) Estimating the avoided fuel-reatment costs of wildfire. Western Journal of Applied Forestry. 23 (4):197-201.

Dorfman JH (1996) Modeling multiple adoption decisions in a joint framework. American Journal of Agricultural Economics 78 (3):547-557

Dostálek J, Weber M, Matula S, Frantík T (2007) Forest stand restoration in the agricultural landscape: The effect of different methods of planting establishment. Ecological Engineering 29 (1):77-86. doi:10.1016/j.ecoleng.2006.07.016

Dubois MR, Glover GR, Straka TJ, Sutton MO (2001) Historic and Projected Economic Returns to Alternative Site Preparation Treatments: The Fayette Study. Southern Journal of Applied Forestry 25 (2):53-59

Duke JM, Dundas SJ, Messer KD (2013) Cost-effective conservation planning: Lessons from economics. Journal of Environmental Management 125:126-133. doi:10.1016/j.jenvman.2013.03.048 
Duvemo K, Lämås T (2006) The influence of forest data quality on planning processes in forestry. Scandinavian Journal of Forest Research 21 (4):327-339. doi:10.1080/02827580600761645

Eid T (2000) Use of uncertain inventory data in forestry scenario models and consequential incorrect harvest decisions. Silva fennica 34 (2):89-100

Espelta JM, Retana J, Habrouk A (2003) An economic and ecological multi-criteria evaluation of reforestation methods to recover burned Pinus nigra forests in NE Spain. Forest Ecology and Management 180 (1):185-198. doi:10.1016/S0378-1127(02)00599-6

Faias SP, Palma JHN, Barreiro SM, Paulo JA, Tomé M (2012) Resource communication. sIMfLOR - platform for portuguese forest simulators. 201221 (3):543-548. doi:10.5424/fs/2012213-02951

Fairbrother A, Turnley JG (2005) Predicting risks of uncharacteristic wildfires: Application of the risk assessment process. Forest Ecology and Management 211 (1-2):28-35. doi:10.1016/j.foreco.2005.01.026

Feder G, Umali DL (1993) The adoption of agricultural innovations: A review. Technological Forecasting and Social Change 43 (3):215-239. doi:10.1016/0040-1625(93)90053-A

Foltz JD (2003) The Economics of Water-Conserving Technology Adoption in Tunisia: An Empirical Estimation of Farmer Technology Choice. Economic Development and Cultural Change 51 (2):359373. doi:10.1086/367627

FORSYS (2012) Forest Management Decision Support Systems (FORSYS).

Gan J, Kolison Jr SH, Miller JH, Hargrove TM (1998) Effects of site preparation on timber and non-timber values of loblolly pine plantations. Forest Ecology and Management 107 (1-3):47-53

Ganz D, Durst P (2003) Assisted natural regeneration: an overview. In: Ganz D, Durst P, Dugan P, Mc Kenzie $\mathrm{P}$ (eds) Advancing assisted natural regeneration (ANR) in Asia and the Pacific. Rap Publication 19, Food and Agriculture Organization of the United Nations Regional Office For Asia and the Pacific, Bangkok, Thailand

Gao Y, Qiu GY, Shimizu H, Tobe K, Sun B, Wang J (2002) A 10-year study on techniques for vegetation restoration in a desertified salt lake area. Journal of Arid Environments 52 (4):483-497

García D, Houle G (2005) Fine-scale spatial patterns of recruitment in red oak (Quercus rubra): what matters most, abiotic or biotic factors? Ecoscience 12 (2):223-225

García S, Rodriguez E, Miralles I, Luna L, Domene MA, Solé A, Cantón Y (2018) Water harvesting techniques based on terrain modification enhance vegetation survival in dryland restoration. CATENA 167:319326. doi:10.1016/j.catena.2018.05.004

Gardiner BA, Quine CP (2000) Management of forests to reduce the risk of abiotic damage-a review with particular reference to the effects of strong winds. Forest Ecology and Management 135 (1):261-277

Geissdoerfer M, Savaget P, Bocken NMP, Hultink EJ (2017) The Circular Economy - A new sustainability paradigm? Journal of Cleaner Production 143:757-768. doi:10.1016/j.jclepro.2016.12.048

Gilliams S, Raymaekers D, Muys B, Orshoven JV (2005) Comparing multiple criteria decision methods to extend a geographical information system on afforestation. Computers and Electronics in Agriculture 49 (1):142-158. doi:10.1016/j.compag.2005.02.011

Gómez L, Pérez IM, Mendoza I, Matías L, Quero JL, Castro J, Zamora R, Marañón T (2008) Oak seedling survival and growth along resource gradients in Mediterranean forests: implications for regeneration in current and future environmental scenarios. Oikos 117 (11):1683-1699. doi:10.1111/j.16000706.2008.16814.x

Gómez V, Elena R (1997) Investigación de las marras causadas por factores ecológicos de naturaleza meteorológica. Cuadernos de la Sociedad Española de las Ciencias Forestales 4:13-25

Gordon SN, Floris A, Boerboom L, Lämås T, Eriksson LO, Nieuwenhuis M, García J, Rodriguez L (2014) Studying the use of forest management decision support systems: an initial synthesis of lessons 
learned from case studies compiled using a semantic wiki. Scandinavian Journal of Forest Research 29 (sup1):44-55. doi:10.1080/02827581.2013.856463

Granhus A, Fjeld D (2008) Time consumption of planting after partial harvests. Silva fennica 42 (1):49

Grêt-Regamey A, Sirén E, Brunner SH, Weibel B (2017) Review of decision support tools to operationalize the ecosystem services concept. Ecosystem Services 26 (Part B):306-315. doi:10.1016/j.ecoser.2016.10.012

Guo Z, Xiao X, Gan Y, Zheng Y (2001) Ecosystem functions, services and their values-a case study in Xingshan County of China. Ecological economics 38 (1):141-154. doi:10.1016/S0921-8009(01)00154-9

Guo Z, Xiao X, Li D (2000) An assessment of ecosystem services: water flow regulation and hydroelectric $\begin{array}{lllll}\text { power production. Ecological Applications } 10 & \text { (3):925-936. doi:10.1890/1051- }\end{array}$ 0761(2000)010[0925:AAOESW]2.0.CO;2

Gupta GN (1991) Effects of mulching and fertilizer application on initial development of some tree species. Forest Ecology and Management 44 (2-4):211-221. doi:10.1016/0378-1127(91)90009-K

Haddock J, Tzanopoulos J, Mitchley J, Fraser R (2007) A method for evaluating alternative landscape management scenarios in relation to the biodiversity conservation of habitats. Ecological economics $61(2-3): 277-283$

Hanewinkel M (2009) The role of economic models in forest management. CAB Reviews: Perspectives in Agriculture, Veterinary Science, Nutrition and Natural Resources 4 (031):1-10

Hanley N, Spash C (1993) The value of biodiversity in British forests. Report to the Forestry Commission. University of Stirling, Scotland

Hausmann R, Hidalgo C (2014) The Atlas of Economic Complexity: Mapping Paths to Prosperity. MIT Press Books

Hawkins CB, Steele TW, Letchford T (2006) The economics of site preparation and the impacts of current forest policy: evidence from central British Columbia. Canadian Journal of Forest Research 36 (2):482494. doi:10.1139/x05-262

Hein L, Van Koppen K, De Groot RS, Van Ierland EC (2006) Spatial scales, stakeholders and the valuation of ecosystem services. Ecological Economics 57 (2):209-228

Hepburn CJ, Koundouri P (2007) Recent advances in discounting: Implications for forest economics. Journal of Forest Economics 13 (2):169-189. doi:10.1016/j.jfe.2007.02.008

Herrera CM (1992) Historical effects and sorting processes as explanations for contemporary ecological patterns: character syndromes in Mediterranean woody plants. American Naturalist 140 (3):421-446. doi:10.1086/285420

Hobbs RJ, Harris JA (2001) Restoration ecology: repairing the earth's ecosystems in the new millennium. Restoration Ecology 9 (2):239-246. doi:10.1046/j.1526-100x.2001.009002239.x

Hochstrasser T, Millington JDA, Papanastasis VP, Parsons AJ, Roggero PP, Brazier RE, Estrany J, Farina A, Puttock A (2014) The Study of Land Degradation in Drylands: State of the Art. In: Mueller EN, Wainwright J, Parsons AJ, Turnbull L (eds) Patterns of Land Degradation in Drylands: Understanding Self-Organised Ecogeomorphic Systems. Springer Netherlands, Dordrecht, pp 13-54. doi:10.1007/978-94-007-5727-1_2

Hoekstra AY, Gerbens-Leenes W, Van der Meer TH (2009) Reply to Pfister and Hellweg: Water footprint accounting, impact assessment, and life-cycle assessment. Proceedings of the National Academy of Sciences 106 (40):E114. doi:10.1073/pnas.0909948106

Holl KD, Howarth RB (2000) Paying for restoration. Restoration Ecology 8:260-267

Holmes TP, Bergstrom JC, Huszar E, Kask SB, Orr F (2004) Contingent valuation, net marginal benefits, and the scale of riparian ecosystem restoration. Ecological economics 49 (1):19-30. doi:10.1016/j.ecolecon.2003.10.015 
Hsu S-L, Loomis J (2002) A defense of cost-benefit analysis for natural resource policy. Environmental Law Reporter News and Analysis 32 (2):10239-10244

Huang G, Chang N (2003) The perspectives of environmental informatics and systems analysis. Journal of Environmental Informatics 1 (1):1-7

Hyde W (1980) Timber supply, land allocation, and economic efficiency. 1 edn. Johns Hopkins University Press, Baltimore

Hyytiäinen K, Ilomäki S, Mäkelä A, Kinnunen K (2006) Economic analysis of stand establishment for Scots pine. Canadian Journal of Forest Research 36 (5):1179-1189. doi:10.1139/x06-023

Hyytiäinen K, Tahvonen O (2003) Maximum Sustained Yield, Forest Rent or Faustmann: Does it Really Matter? Scandinavian Journal of Forest Research 18 (5):457-469. doi:10.1080/02827580310013235

Ivetić V (2015) Reforestation in Serbia: success or failure? In: International Conference: Reforestation Challenges, Belgrade, Serbia, 3-6 June 2015 Proceedings, 2015. REFORESTA, pp 1-12

Ivetić V, Devetaković J (2016) Reforestation challenges in Southeast Europe facing climate change. Reforesta 1:178-220. doi:10.21750/10.21750/refor.1.10.10

Jacobs DF, Oliet JA, Aronson J, Bolte A, Bullock JM, Donoso PJ, Landhäusser SM, Madsen P, Peng S, Rey JM, Weber JC (2015) Restoring forests: What constitutes success in the twenty-first century? New Forests 46 (5):601-614. doi:10.1007/s11056-015-9513-5

James JJ, Sheley RL, Erickson T, Rollins KS, Taylor MH, Dixon KW (2013) A systems approach to restoring degraded drylands. Journal of Applied Ecology 50 (3):730-739

JCYL (2007) Requerimientos técnicos. Forestación de tierras agrícolas 2007-2013 Consejería de Fomento y Medio Ambiente. Junta de Castilla y León, Valladolid, España

Jensen R (1982) Adoption and diffusion of an innovation under uncertain profitability. Journal of economic theory 27 (1):182-199

Jia S, Long Q, Liu W (2017) The fallacious strategy of virtual water trade. International Journal of Water Resources Development 33 (2):340-347. doi:10.1080/07900627.2016.1180591

Jiménez MN, Fernández E, Ripoll MA, Castro J, Huntsinger L, Navarro FB (2013) Stones and organic mulches improve the Quercus ilex L. afforestation success under Mediterranean climatic conditions. Land Degradation and Development 27 (2):357-365. doi:10.1002/ldr.2250

Johansson K, Nilsson U, Örlander G (2013) A comparison of long-term effects of scarification methods on the establishment of Norway spruce. Forestry: An International Journal of Forest Research 86 (1):9198. doi:10.1093/forestry/cps062

Johnson KN, Gordon S, Duncan S, Lach D, McComb B, Reynolds K (2007) Conserving Creatures of the Forest: A Guide to Decision Making and Decision Models for Forest Biodiversity

Johnson P, Shifley S, Rogers R (2002) The Ecology and Silviculture of Oaks. CABI. New York

Jones PD, Grado SC, Demarais S (2010) Financial analysis of intensive pine plantation establishment. Journal of Forest Economics 16 (2):101-112. doi:10.1016/j.jfe.2009.09.001

Joslin J, Wolfe M, Hanson P (2000) Effects of altered water regimes on forest root systems. The New Phytologist 147: 117-129

Kangas A, Kangas J, Kurttila M (2008) Decision support for forest management. Springer

Kangas J, Kangas A (2005) Multiple criteria decision support in forest management - the approach, methods applied, and experiences gained. Forest Ecology and Management 207 (1):133-143. doi:10.1016/j.foreco.2004.10.023

Kankaanhuhta V, Saksa T (2013) Cost-Quality Relationship of Norway Spruce Planting and Scots Pine Direct Seeding in Privately Owned Forests in Southern Finland. Scandinavian Journal of Forest Research 28 (5):481-492. doi:10.1080/02827581.2013.773065 
Kanowski PJ (1997) Afforestation and plantation forestry. Paper presented at the Proceedings of the XI World Forestry Congress, Antalya, Turkey, 13-22 October 1997

Kassie M, Jaleta M, Shiferaw B, Mmbando F, Mekuria M (2013) Adoption of interrelated sustainable agricultural practices in smallholder systems: Evidence from rural Tanzania. Technological Forecasting and Social Change 80 (3):525-540. doi:10.1016/j.techfore.2012.08.007

Kassie M, Teklewold H, Jaleta M, Marenya P, Erenstein O (2015) Understanding the adoption of a portfolio of sustainable intensification practices in eastern and southern Africa. Land Use Policy 42:400-411. doi:10.1016/j.landusepol.2014.08.016

Keefe K, Alavalapati J, Pinheiro C (2012) Is enrichment planting worth its costs? A financial cost-benefit analysis. Forest Policy and Economics 23:10-16

Kettenring KM, Adams CR (2011) Lessons learned from invasive plant control experiments: a systematic review and meta-analysis. Journal of Applied Ecology 48 (4):970-979. doi:10.1111/j.13652664.2011.01979.x

Khamzina A, Lamers J, Vlek P (2008) Tree establishment under deficit irrigation on degraded agricultural land in the lower Amu Darya River region, Aral Sea Basin. Forest Ecology and Management 255 (1):168-178

Klerkx L, Aarts N, Leeuwis C (2010) Adaptive management in agricultural innovation systems: The interactions between innovation networks and their environment. Agricultural Systems 103 (6):390400. doi:10.1016/j.agsy.2010.03.012

Kline JD (2004) Issues in evaluating the costs and benefits of fuel treatments to reduce wildfire in the Nation's forests. Portland

Kniivilä M, Saastamoinen O (2002) The opportunity costs of forest conservation in a local economy. Silva fennica $36(4): 853-865$

Knoke T, Paul C, Härtl F (2017) A critical view on benefit-cost analyses of silvicultural management options with declining discount rates. Forest Policy and Economics 83:58-69. doi:https://doi.org/10.1016/j.forpol.2017.06.005

Kribeche H, Bautista S, Chirino E, Vilagrosa A, Vallejo VR (2012) Effects of landscape spatial heterogeneity on dryland restoration success. The combined role of site conditions and reforestation techniques in southeastern Spain. International Journal of Mediterranean Ecology 38 (1):5-17

Kula E (1988) Future generations: the modified discounting method. Project Appraisal 3 (2):85-88. doi:10.1080/02688867.1988.9726662

Kull D, Mechler R, Hochrainer-Stigler S (2013) Probabilistic cost-benefit analysis of disaster risk management in a development context. Disasters 37 (3):374-400

Lake PS (2001) On the maturing of restoration: linking ecological research and restoration. Ecological Management and Restoration 2 (2):110-115. doi:10.1046/j.1442-8903.2001.00074.x

Lapointe L, Rivard S (2005) A Multilevel Model of Resistance to Information Technology Implementation. MIS Quarterly 29 (3):461-491. doi:10.2307/25148692

Läpple D, Renwick A, Cullinan J, Thorne F (2016) What drives innovation in the agricultural sector? A spatial analysis of knowledge spillovers. Land Use Policy 56:238-250. doi:10.1016/j.landusepol.2016.04.032

Läpple D, Renwick A, Thorne F (2015) Measuring and understanding the drivers of agricultural innovation: Evidence from Ireland. Food Policy 51:1-8. doi:10.1016/j.foodpol.2014.11.003

Laumer S, Eckhardt A (2012) Why do people reject technologies: a review of user resistance theories. In: Dwivedi YK, Wade WR, Schneberger SL (eds) Information systems theory. Springer, New York, pp 63-86 
Launiainen S, Futter MN, Ellison D, Clarke N, Finér L, Högbom L, Laurén A, Ring E (2014) Is the water footprint an appropriate tool for forestry and forest products: The Fennoscandian case. Ambio 43 (2):244-256

Le HD, Smith C, Herbohn J (2014) What drives the success of reforestation projects in tropical developing countries? The case of the Philippines. Global Environmental Change 24 (Supplement C):334-348. doi:10.1016/j.gloenvcha.2013.09.010

Lemieux C, Delisle C (1998) Using cover crops to establish white and black spruce on abandoned agricultural lands. Phytoprotection 79:21-33. doi:10.7202/706132ar

León MF, Squeo FA, Gutiérrez JR, Holmgren M (2011) Rapid root extension during water pulses enhances establishment of shrub seedlings in the Atacama Desert. Journal of Vegetation Science 22 (1):120-129. doi:10.1111/j.1654-1103.2010.01224.x

Lexer MJ, Vacik H, Palmetzhofer D, Oitzinger G (2005) A decision support tool to improve forestry extension services for small private landowners in southern Austria. Computers and Electronics in Agriculture 49 (1):81-102. doi:10.1016/j.compag.2005.02.004

Lien G, Størdal S, Hardaker JB, Asheim L (2007) Risk aversion and optimal forest replanting: A stochastic efficiency study. European Journal of Operational Research 181 (3):1584-1592

Liu J, Zehnder AJB, Yang H (2009) Global consumptive water use for crop production: The importance of green water and virtual water. Water Resources Research 45 (5):W05428. doi:10.1029/2007WR006051

Liley B (2000) Focus on the treatment of risk in forest valuations. New Zealand Journal of Forestry 45 (2):312

Löf M, Dey DC, Navarro RM, Jacobs DF (2012) Mechanical site preparation for forest restoration. New Forests 43 (5-6):825-848. doi:10.1007/s11056-012-9332-x

Logar I, Van den Bergh JCJM (2011) Methods for Assessment of the Costs of Droughts. CONHAZ Report. CONHAZ Consortium

Long TB, Blok V, Coninx I (2016) Barriers to the adoption and diffusion of technological innovations for climate-smart agriculture in Europe: evidence from the Netherlands, France, Switzerland and Italy. Journal of Cleaner Production 112:9-21. doi:10.1016/j.jclepro.2015.06.044

Ludwig JA, Tongway DJ (1997) A landscape approach to rangeland ecology. In: Ludwig J, Tongway, D., Freudenberger, D., Noble, J y Hodgkinson, K. (ed) Landscape Ecology Function and Management: Principles from Australia's Rangelands. CSIRO, Melbourne, Australia, pp 1-12

MA (2003) Millennium Ecosystem Assessment. Ecosystems and human well-being: A Framework for Assessment. Island Press Washington

Macmillan DC, Harley D, Morrison R (1998) Cost-effectiveness analysis of woodland ecosystem restoration. Ecological Economics 27 (3):313-324

Maestre F, Cortina J, Bautista S, Bellot J, Vallejo VR (2003) Small scale environmental heterogeneity and spatiotemporal dynamics of seedling establishment in a semiarid degraded ecosystem. Ecosystems 6:630-643

Maestre FT, Cortina J (2004) Are Pinus halepensis plantations useful as a restoration tool in semiarid Mediterranean areas? Forest Ecology and Management 198:303-3174

Mangaoang EO (2002) A Forester's Perspective of the Socio-economic Information Requirements for Forestry in Leyte. In: Harrison S, Herbohn J, Mangaoang E, Vanclay J (eds) Socio-economic Research Methods in Forestry: A Training Manual Proceedings of an International Training Workshop held in the College of Forestry at Leyte State University, Visca, Baybay, The Philippines, over the period 410 February, 2002. Cooperative Research Centre for Tropical Rainforest Ecology and Management. Rainforest CRC, Cairns 
Manso R, Fortin M, Calama R, Pardos M (2013) Modelling seed germination in forest tree species through survival analysis. The Pinus pinea L. case study. Forest Ecology and Management 289 (Supplement C):515-524. doi:10.1016/j.foreco.2012.10.028

Margolis H, Brand D (1990) An ecophysiological basis for understanding plantation establishment. Canadian Journal of Forest Research 20 (4):375-390

Martin J, Runge MC, Nichols JD, Lubow BC, Kendall WL (2009) Structured decision making as a conceptual framework to identify thresholds for conservation and management. Ecological Applications 19 (5):1079-1090

Martínez de Azagra A (1994) Modelo para la estimación de la disponibilidad hídrica en laderas. I Fundamentos del modelo. Escuela Técnica Superior de Ingenierías Agrarias-Instituto Nacional para al Conservación de la Naturaleza, Palencia, España

Martínez de Azagra A (2002) Principles for designing endorheic microcatchments. In: Morgans P, Asins A, Andreu V (eds) Proceedings of the Third International Congress of the European Society for Soil Conservation (ESSC) Man and Soil at the Third Millennium Valencia, 28 March-1 April, 2002. Logroño, pp 507-521

Martínez de Azagra A, del Río J (2012) Los riegos de apoyo y de socorro en repoblaciones forestales. Foresta (54):32-44

Martínez de Azagra A, Mongil J, Rojo L (2004) Oasification: a forest solution to many problems of desertificacion. Forest System 13 (3):437-422

Martínez F, Oria de Rueda J, Ágreda T (2011) Manual para la gestión del recurso micológico forestal en Castilla y León. Serie Técnica de la Junta de Castilla y León:453

Martínez-Vilalta J, Piñol J, Beven K (2002) A hydraulic model to predict drought-induced mortality in woody plants: an application to climate change in the Mediterranean. Ecological Modelling 155 (2):127-147. doi:10.1016/S0304-3800(02)00025-X

Masiero M, Secco L, Pettenella D, Brotto L (2015) Standards and guidelines for forest plantation management: A global comparative study. Forest policy and economics 53:29-44. doi:10.1016/j.forpol.2014.12.008

Mason E (1995) Decision tools for establishing forest plantations. In: Power JM, Strome M, Daniel TC (eds) Proceedings of Decision-support 2001 Conference, Toronto, Canada, September 12-16 1995. pp 634648

Mason EG, Geddes DJ, Richardson B, Davenhill NA (1991) Application of knowledge-based programming techniques to cost-effective selection of herbicides in forestry. In: Whyte AGD (ed) Proceedings of Australian and New Zealand Institutes of Foresters conference on "The costs and benefits of change". Christchurch, pp 310-318

Matthews JW, Spyreas G, Endress AG (2009) Trajectories of vegetation-based indicators used to assess wetland restoration progress. Ecological Applications 19 (8):2093-2107. doi:10.1890/08-1371.1

McDowell N, Pockman WT, Allen CD, Breshears DD, Cobb N, Kolb T, Plaut J, Sperry J, West A, Williams DG (2008) Mechanisms of plant survival and mortality during drought: why do some plants survive while others succumb to drought? New phytologist 178 (4):719-739

Mechler R (2016) Reviewing estimates of the economic efficiency of disaster risk management: opportunities and limitations of using risk-based cost-benefit analysis. Natural Hazards 81 (3):2121-2147. doi:10.1007/s11069-016-2170-y

Meijer ISM, Hekkert MP, Koppenjan JFM (2007) The influence of perceived uncertainty on entrepreneurial action in emerging renewable energy technology; biomass gasification projects in the Netherlands. Energy Policy 35 (11):5836-5854. doi:10.1016/j.enpol.2007.07.009

Mendoza GA (1986) A heuristic programming approach in estimating efficient target levels in goal programming. Canadian Journal of Forest Research 16 (2):363-366. doi:10.1139/x86-062 
Miina J, Saksa T (2008) Predicting establishment of tree seedlings for evaluating methods of regeneration for Pinus sylvestris. Scandinavian Journal of Forest Research 23 (1):12-27. doi:10.1080/02827580701779595

Miller JR, Hobbs RJ (2007) Habitat restoration-do we know what we're doing? Restoration Ecology 15 (3):382-390. doi:10.1111/j.1526-100X.2007.00234.x

Moles AT, Westoby M (2004) What do seedlings die from and what are the implications for evolution of seed size? Oikos 106 (1):193-199. doi:10.1111/j.0030-1299.2004.13101.x

Montalvo AM, Williams SL, Rice KJ, Buchmann SL, Cory C, Handel SN, Nabhan GP, Primack R, Robichaux RH (1997) Restoration Biology: A Population Biology Perspective. Restoration Ecology 5 (4):277-290. doi:10.1046/j.1526-100X.1997.00542.x

Muys B, Hynynen J, Palahi M, Lexer MJ, Fabrika M, Pretzsch H, Gillet F, Briceño E, Nabuurs G-J, Kint V (2010) Simulation tools for decision support to adaptive forest management in Europe. Forest Systems 19:86-99

Naciones Unidas (2015) Transformar nuestro mundo: la Agenda 2030 para el Desarrollo Sostenible. Resolución aprobada por la Asamblea General el 25 de septiembre de 2015 (A/RES/70/1)

Navarro RM, del Campo AD, Cortina JF (2006) Factores que afectan al éxito de una repoblación y su relación con la calidad de la planta. In: Cortina J, Peñuelas JL, Puértolas J, Vilagrosa A, Savé R (eds) Calidad de planta forestal para la restauración en ambientes Mediterráneos Estado actual de conocimientos. Organismo Autónomo Parques Nacionales. Ministerio de Medio Ambiente, Madrid

Navarro RM, Guzamán R, Herrera N, Lara PA, Torres MA, Ceacero C, Del Campo A, Bautista S (2009) Land Restoration to Combat Desertification. In: Bautista S, Aronson J, Vallejo VR (eds) Innovative Approaches, Quality Control and Project Evaluation Fundación CEAM. pp 73-86

Navarro RM, Martínez A (1997) Las marras producidas por ausencia de cuidados culturales. Cuadernos de la SECF 4:43-57

Navarro RM, del Campo AD, Ceacero CJ, Quero JL, Hermoso de Mena J (2014) On the importance of topography, site quality, stock quality and planting date in a semiarid plantation: Feasibility of using low-density LiDAR. Ecological Engineering 67:25-38. doi:10.1016/j.ecoleng.2014.03.011

Newman DH (1988) The optimal forest rotation: A Discussion and Annotated Bibliography. General Technical Report. USDA Southeastern Forest Experiment Station, Asheville

Nijnik M, Pajot G, Moffat AJ, Slee B (2013) An economic analysis of the establishment of forest plantations in the United Kingdom to mitigate climatic change. Forest Policy and Economics 26:34-42. doi: 10.1016/j.forpol.2012.10.002

Nobre S, Eriksson LO, Trubins R (2016) The Use of Decision Support Systems in Forest Management: Analysis of FORSYS Country Reports. Forests 7 (3):72

Noelia JM, Emilia FO, Ángeles RM, Juan CR, Lynn H, Bruno NF (2016) Stones and Organic Mulches Improve the Quercus Ilex L. Afforestation Success Under Mediterranean Climatic Conditions. Land Degradation and Development 27 (2):357-365. doi:doi:10.1002/ldr.2250

Oliet JA, Jacobs DF (2012) Restoring forests: advances in techniques and theory. New Forests:1-7

Oria de Rueda JA (2007) Hongos y setas. Tesoro de nuestros montes. Cálamo, Palencia

Ovando P, Campos P, Calama R, Montero G (2010) Landowner net benefit from stone pine (Pinus pinea L.) afforestation of dry-land cereal fields in Valladolid, Spain. Journal of Forest Economics 16 (2):83-100

Padilla FM, Pugnaire FI (2007) Rooting depth and soil moisture control Mediterranean woody seedling survival during drought. Functional Ecology 21 (3):489-495. doi:10.1111/j.1365-2435.2007.01267.x

Padilla FM, Pugnaire FI (2009) Species Identity and Water Availability Determine Establishment Success Under the Canopy of Retama sphaerocarpa Shrubs in a Dry Environment. Restoration Ecology 17 (6):900-907. doi:10.1111/j.1526-100X.2008.00460.x 
Pakparvar M, Cornelis W, Pereira LS, Gabriels D, Hosseinimarandi H, Edraki M, Kowsar SA (2014) Remote sensing estimation of actual evapotranspiration and crop coefficients for a multiple land use arid landscape of southern Iran with limited available data. Journal of Hydroinformatics 16 (6):1441-1460. doi:10.2166/hydro.2014.140

Palacios G, Navarro RM, Del Campo A, Toral M (2009) Site preparation, stock quality and planting date effect on early establishment of Holm oak (Quercus ilex L.) seedlings. Ecological Engineering 35 (1):3846. doi:10.1016/j.ecoleng.2008.09.006

Palmer M, Allan JD, Meyer J, Bernhardt ES (2007) River restoration in the twenty-first century: data and experiential knowledge to inform future efforts. Restoration Ecology 15 (3):472-481

Palmerlee AP, Young TP (2010) Direct seeding is more cost effective than container stock across ten woody species in California. Native Plants Journal 11 (2):89-102. doi:10.2979/NPJ.2010.11.2.89

Pardos M, Calama R, Mayoral C, Madrigal G, Sánchez M (2015) Addressing post-transplant summer water stress in Pinus pinea and Quercus ilex seedlings (Addressing post-transplant summer water stress in Pinus pinea and Quercus ilex seedlings). iForest - Biogeosciences and Forestry 8 (3):348-358. doi:10.3832ifor1256-007

Pasalodos M, Mäkinen A, García J, Borges J, Lämås T, Eriksson L (2013) Assessing uncertainty and risk in forest planning and decision support systems: review of classical methods and introduction of new approaches. Forest Systems 22 (2):282-303

Pasalodos M, Pukkala T, Calama R, Cañellas I, Sánchez M (2016) Optimal management of Pinus pinea stands when cone and timber production are considered. European Journal of Forest Research 135 (4):607619. doi:10.1007/s10342-016-0958-7

Pastorella F, Borges J, De Meo I (2016) Usefulness and perceived usefulness of Decision Support Systems (DSSs) in participatory forest planning: the final users; point of view. iForest - Biogeosciences and Forestry 9 (3):422-429. doi:10.3832ifor1356-008

Pausas J, Bladé C, Valdecantos A, Seva J, Fuentes D, Alloza J, Vilagrosa A, Bautista S, Cortina J, Vallejo VR (2004) Pines and oaks in the restoration of Mediterranean landscapes of Spain: New perspectives for an old practice - a review. Plant Ecology 171 (1-2):209-220. doi:10.1023/b:vege.0000029381.63336.20

Pedigo LP, Hutchins SH, Higley LG (1986) Economic injury levels in theory and practice. Annual Review of Entomology 31 (1):341-368

Pemán J, Navarro RM, Serrada R (2006) Elección de especies en las repoblaciones forestales. Contribuciones del profesor Ruiz de la Torre. Investigación Agraria Sistemas y Recursos Forestales, 2006, vol 15, núm $4, \mathrm{p} 87-102$

Pemán J (2015) Lecciones aprendidas y tareas pendientes en la actividad repobladora y viverística. Cuadernos de la Sociedad Española de las Ciencias Forestales 39:177-195

Pemán J, Vadell E (2009) Reconstrucción de la estadística de la actividad repobladora desde 1879 hasta nuestros días. In: Sociedad Española de las Ciencias Forestales-Junta de Castilla y León (eds) Actas $5^{\circ}$ Congreso Forestal Español CD-Rom. Sociedad Española de Ciencias Forestales, Pontevedra

Peñuelas JL, Ocaña L, Domínguez-Lerena S, Renilla I (1996) Experiencias sobre el control de la competencia herbacea en repoblaciones de terrenos agricolas abandonados. Montes 45:30-36

Perks MP, Harrison AJ, Bathgate SJ (2007) Establishment Management Information System (EMIS): delivering good practice advice on tree establishment in the uplands of Britain. In: Reynolds, K.M, Thomson AJ, Köhl M, Shannon MA, Ray D, Rennolls K (eds) Sustainable forestry: from monitoring and modelling to knowledge management and policy science CAB International, Wallingford. CABI, Cambridge, USA, pp 412-424

Petridis NE, Digkas G, Anastasakis L (2018) Factors affecting innovation and imitation of ICT in the agrifood sector. Annals of Operations Research. doi:10.1007/s10479-018-2834-y

Pinjuv G, Daugherty P, Fox BE (2001) Cost/effectiveness analysis of ponderosa pine ecosystem restoration in Flagstaff Arizona's wildland-urban interface. In: Vance, Regina K; Edminster, Carleton B; 
Covington, W Wallace; Blake, Julie A, comps Ponderosa pine ecosystems restoration and conservation: steps toward stewardship; 2000 April 25-27; Flagstaff, AZ Proceedings RMRS-P-22 Ogden, UT: US Department of Agriculture, Forest Service, Rocky Mountain Research Station p 149153 22:149-153

Pôças I, Paço TA, Cunha M, Andrade JA, Silvestre J, Sousa A, Santos FL, Pereira LS, Allen RG (2014) Satellitebased evapotranspiration of a super-intensive olive orchard: Application of METRIC algorithms. Biosystems Engineering 128:69-81. doi:10.1016/j.biosystemseng.2014.06.019

Potts JB, Marino E, Stephens SL (2010) Chaparral shrub recovery after fuel reduction: a comparison of prescribed fire and mastication techniques. Plant Ecology 210 (2):303-315. doi:10.1007/s11258-0109758-1

Puértolas J, Gil L, Pardos JA (2003) Effects of nutritional status and seedling size on field performance of Pinus halepensis planted on former arable land in the Mediterranean basin. Forestry 76 (2):159-168

Pukkala T (1998) Multiple risks in multi-objective forest planning: integration and importance. Forest Ecology and Management 111 (2):265-284

Pywell RF, Bullock JM, Tallowin JB, Walker KJ, Warman EA, Masters G (2007) Enhancing diversity of species-poor grasslands: An experimental assessment of multiple constraints. Journal of Applied Ecology 44 (1):81-94

Querejeta JI, Roldán A, Albaladejo J, Castillo V (2001) Soil water availability improved by site preparation in a Pinus halepensis afforestation under semiarid climate. Forest Ecology and Management 149 (13):115-128

Reque JA, Bravo F (1993) Experiencias en repoblaciones con placas de mulch en la comarca del cerrato palentino; resultados preliminares. In: Silva-Pando FJ, Alonso GV (eds) Actas del Congreso Forestal Español-Lourizán 93. vol Tomo II. Grapol, Vigo, pp 427-431

Reque JA, Martin E (2015) Designing acorn protection for direct seeding of quercus species in high predation areas. 201524 (1). doi:10.5424/fs/2015241-05632

Rey JM (1998) Growth and survival in Quercus ilex L. seedlings after irrigation and artificial shading on Mediterranean set-aside agricultural land. Annals of Forest Science 55 (7):801-807

Rey JM, Camacho A (2004) Performance of Quercus ilex saplings planted in abandoned Mediterranean cropland after long-term interruption of their management. Forest Ecology and Management 194 (13):223-233. doi:10.1016/j.foreco.2004.02.035

Rey JM, Cuesta B, Villar P, Jáuregui P (2008) Life-history traits in an evergreen Mediterranean oak respond differentially to previous experimental environments. Web Ecology 8 (1):74-83. doi:10.5194/we-8-742008

Rey JM, López-Pintor A, García C, De la Cámara N, Strasser R, Gomez Sal A (2002) Early establishment of planted Retama sphaerocarpa seedlings under different levels of light, water and weed competition. Plant Ecology 159 (2):201-209. doi:10.1023/a:1015562623751

Rey JM, Martínez-Baroja L, Pérez-Camacho L, Villar-Salvador P, Holl KD (2015) Predation and aridity slow down the spread of 21-year-old planted woodland islets in restored Mediterranean farmland. New Forests 46 (5):841-853. doi:10.1007/s11056-015-9490-8

Rey JM, Navarro J, Espigares T, Nicolau JM, Zavala MA (2005) Effects of artificial shading and weed mowing in reforestation of Mediterranean abandoned cropland with contrasting Quercus species. Forest Ecology and Management 212 (1-3):302-314. doi:10.1016/j.foreco.2005.03.032

Reynolds KM, Twery M, Lexer MJ, Vacik H, Ray D, Shao G, Borges JG (2008) Decision Support Systems in Forest Management. In: Handbook on Decision Support Systems 2: Variations. Springer Berlin Heidelberg, Berlin, Heidelberg, pp 499-533. doi:10.1007/978-3-540-48716-6_24

Ridoutt BG, Huang J (2012) Environmental relevance-the key to understanding water footprints. Proceedings of the National Academy of Sciences 109 (22):E1424-E1424 
Rinaldi F, Jonsson R, Sallnäs O, Trubins R (2015) Behavioral modelling in a decision support system. Forests $6(2): 311-327$

Robbins AST, Daniels JM (2012) Restoration and Economics: A Union Waiting to Happen? Restoration Ecology 20 (1):10-17. doi:10.1111/j.1526-100X.2011.00838.x

Rodrigues RR, Lima RAF, Gandolfi S, Nave AG (2009) On the restoration of high diversity forests: 30 years of experience in the Brazilian Atlantic Forest. Biological Conservation 142 (6):1242-1251. doi:10.1016/j.biocon.2008.12.008

Romero C, Ros V, Díaz-Balteiro L (1998) Optimal forest rotation age when carbon captured is considered: theory and applications. Journal of the Operational Research Society 49 (2):121-131. doi:10.1057/palgrave.jors.2600497

Rosa RD, Paredes P, Rodrigues GC, Alves I, Fernando RM, Pereira LS, Allen RG (2012a) Implementing the dual crop coefficient approach in interactive software. 1. Background and computational strategy. Agricultural Water Management 103:8-24. doi:10.1016/j.agwat.2011.10.013

Rosa RD, Paredes P, Rodrigues GC, Fernando RM, Alves I, Pereira LS, Allen RG (2012b) Implementing the dual crop coefficient approach in interactive software: 2. Model testing. Agricultural Water Management 103:62-77. doi:10.1016/j.agwat.2011.10.018

Ruiz J, Carreras C, García JI, Orti M (1996) Manual de la flora para la restauración de áreas críticas y diversificación en masas forestales. Consejería de Medio Ambiente de la Junta de Andalucía, Sevilla, España

Sack L, Grubb PJ (2002) The combined impacts of deep shade and drought on the growth and biomass allocation of shade-tolerant woody seedlings. Oecologia 131 (2):175-185. doi:10.1007/s00442-0020873-0

Saldi K, Bates K, Skidmore P, Barenti J, Pineo D (2004) Stream Habitat Restoration Guidelines. Washington Departments of Fish and Wildlife and Ecology and the U.S. Fish and Wildlife Service., Olympia, Washington

Samiee S, Rezaei K (2017) The proposed alternative model to predict adoption of innovations: The case of no-till technology in Iran. Journal of the Saudi Society of Agricultural Sciences 16 (3):270-279. doi:10.1016/j.jssas.2015.09.002

Sánchez J, Ortega R, Hervás M, Padilla FM, Pugnaire FI (2004) El microrriego, una técnica de restauración de la cubierta vegetal para ambientes semiáridos. Cuadernos de la Sociedad Española de las Ciencias Forestales 17:109-112

Sánchez D, Valladares F, Zavala MA (2006) Performance of seedlings of Mediterranean woody species under experimental gradients of irradiance and water availability: trade-offs and evidence for niche differentiation. New phytologist 170 (4):795-806

Schut M, Klerkx L, Rodenburg J, Kayeke J, Hinnou LC, Raboanarielina CM, Adegbola PY, Van Ast A, Bastiaans L (2015a) RAAIS: Rapid Appraisal of Agricultural Innovation Systems (Part I). A diagnostic tool for integrated analysis of complex problems and innovation capacity. Agricultural Systems 132:1-11. doi:10.1016/j.agsy.2014.08.009

Schut M, Rodenburg J, Klerkx L, Kayeke J, Van Ast A, Bastiaans L (2015b) RAAIS: Rapid Appraisal of Agricultural Innovation Systems (Part II). Integrated analysis of parasitic weed problems in rice in Tanzania. Agricultural Systems 132:12-24. doi:10.1016/j.agsy.2014.09.004

Schut M, Rodenburg J, Klerkx L, Van Ast A, Bastiaans L (2014) Systems approaches to innovation in crop protection. A systematic literature review. Crop Protection 56:98-108. doi:10.1016/j.cropro.2013.11.017

Schut M, van Asten P, Okafor C, Hicintuka C, Mapatano S, Nabahungu NL, Kagabo D, Muchunguzi P, Njukwe E, Dontsop-Nguezet PM, Sartas M, Vanlauwe B (2016) Sustainable intensification of agricultural systems in the Central African Highlands: The need for institutional innovation. Agricultural Systems 145:165-176. doi:10.1016/j.agsy.2016.03.005 
Segura M, Ray D, Maroto C (2014) Decision support systems for forest management: A comparative analysis and assessment. Computers and Electronics in Agriculture 101:55-67. doi:10.1016/j.compag.2013.12.005

Serrada R (2004) Apuntes de Selvicultura. Servicio dePublicaciones. Escuela Universitaria de Ingeniería Técnica Forestal, Madrid, España

Serrada R, Navarro RM, Pemán J (2005) La calidad de las repoblaciones forestales: una aproximación desde la selvicultura y la ecofisiología. Forest Systems 14 (3):462-481

Shono K, Cadaweng EA, Durst PB (2007) Application of Assisted Natural Regeneration to Restore Degraded Tropical Forest Lands. Restoration Ecology 15: 620-626. doi:10.1111/j.1526-100X.2007.00274.x

Sims A, Kiviste A, Hordo M, Laarmann D, Gadow Kv (2009) Estimating tree survival: a study based on the Estonian Forest Research Plots Network. In: Annales Botanici Fennici 46 (4):336-352. doi:10.5735/085.046.0409

Siry JP, Robison DJ, Cubbage FW (2004) Economic Returns Model for Silvicultural Investments in Young Hardwood Stands. Southern Journal of Applied Forestry 28 (4):179-184. doi:10.1093/sjaf/28.4.179

Snider G, Daugherty PJ, Wood D (2006) The Irrationality of Continued Fire Suppression: An Avoided Cost Analysis of Fire Hazard Reduction Treatments Versus No Treatment. Journal of Forestry 104 (8):431437

Snowdon P, Waring H (1984) Long-Term Nature of Growth Responses Obtained to Fertilizer and Weed Control Applied at Planting and Their Consequences for Forest Management. In: Proceedings of the IUFRO Symposium on Site and Productivity of Fast Growing Plantations, Pretoria and Pietermaritzberg, 30 April-11 May 1984 pp 701-711

Stanturf JA, Palik BJ, Dumroese RK (2014) Contemporary forest restoration: A review emphasizing function. Forest Ecology and Management 331:292-323. doi:10.1016/j.foreco.2014.07.029

Stern VM, Smith RF, Van den Bosch R, Hagen KS (1959) The integration of chemical and biological control of the spotted alfalfa aphid. The integrated control concept. Hilgardia 29 (2):81-101

Stone EC (1955) Poor survival and the physiological condition of planting stock. Forest Science 1 (2):90-94

Suding KN (2011) Toward an era of restoration in ecology: successes and failures along the science-practice divide. Ann Rev Ecol Evol Syst 42:465-487. doi:10.1146/annurev-ecolsys-102710-145115

Thayer GW, McTigue TA, Bellmer RJ, Burrows FM, Merkey DH, Nickens AD, Lozano SJ, Gayaldo PF, Polmateer PJ, Pinit PT (2003) Science-Based Restoration Monitoring of Coastal Habitats, I: A Framework for Monitoring Plans Under the Estuaries and Clean Waters Act of 2000 (Public Law 160457). NOAA Coastal Ocean Program Decision Analysis Series No 23 NOAA. National Centers for Coastal Ocean Science, Silver Spring, MD

Thorsen BJ, Helles F (1998) Optimal stand management with endogenous risk of sudden destruction. Forest Ecology and Management 108 (3):287-299

Thorsen BJ, Malchow-Møller N (2003) Afforestation as a real option: Choosing among options. In: Recent Accomplishments in Applied Forest Economics Research. Springer, pp 73-80

Tilló J (2006) Riego por exudación. Ponencia al Congreso Internacional ApliMatec 06 (Aplicaciones Técnicas de los Materiales Textiles). Valencia. Spain

Torreano SJ, Morris LA (1998) Loblolly Pine Root Growth and Distribution under Water Stress. Soil Science Society of America Journal 62 (3):818-827. doi:10.2136/sssaj1998.03615995006200030040x

UNCCD (2017) Global Land Outlook. In: United Nations (ed). UN Convention to Combat Desertification, Bonn

UNEP (1997) Sourcebook of alternative technologies for freshwater augmentation in Latin America and the Caribbean. Chapters 4.2 y 5.7 (about porous capsules). UNEP / OAS. Washington. Available on http://www.greenstone.org/ 
Unidas N (2015) Transformar nuestro mundo: la Agenda 2030 para el Desarrollo Sostenible. Resolución aprobada por la Asamblea General el 25 de septiembre de 2015. Vol A/RES/70/1, 21 de octubre. Naciones Unidas, Nueva York

Uotila K, Rantala J, Saksa T, Harstela P (2010) Effect of soil preparation method on economic result of Norway spruce regeneration chain, vol 44. vol 3. doi:10.14214/sf.146

Vacik H, Lexer MJ (2014) Past, current and future drivers for the development of decision support systems in forest management. Scandinavian Journal of Forest Research 29 (sup1):2-19. doi:10.1080/02827581.2013.830768

Vadell E, De Miguel S, Pemán J (2016) Large-scale reforestation and afforestation policy in Spain: a historical review of its underlying ecological, socioeconomic and political dynamics. Land Use Policy 55:37-48

Vallejo VR, Aronson J, Pausas JG, Cortina J (2005) Restoration of Mediterranean woodlands. In: van Andel J AJ (ed) Restoration ecology: a European perspective Blackwell Science, Oxford, UK, pp 193-207

Vallejo VR, Allen EB, Aronson J, Pausas JG, Cortina J, Gutierrez JR (2012) Restoration of MediterraneanType Woodlands and Shrublands. In: Restoration Ecology. John Wiley and Sons, Ltd, pp 130-144. doi:10.1002/9781118223130.ch11

Van Jaarsveld EJ, Pond U (2013) Uncrowned Monarch of the Namib: Welwitschia mirabilis. Penrock publications

Vandermeer J, Perfecto I (2013) Complex traditions: Intersecting theoretical frameworks in agroecological research. Agroecology and Sustainable Food Systems 37 (1):76-89. doi:10.1080/10440046.2012.717904

Wainger LA, King DM, Mack RN, Price EW, Maslin T (2010) Can the concept of ecosystem services be practically applied to improve natural resource management decisions? Ecological economics 69 (5):978-987. doi:10.1016/j.ecolecon.2009.12.011

Walker HD (1985) An alternative approach to goal programming. Canadian Journal of Forest Research 15 (2):319-325. doi:10.1139/x85-052

Waters C, Young AG, Crosthwaite J (2007) Genetic Integrity as a Target for Natural Capital Restoration: Weighing the Costs and Benefits. In: J. Aronson, S. J. Milton, Blignaut JN (eds) Restoring natural capital: science, business, and practice. Island press, pp 85-93

Weiss G (2011) Theoretical Approaches for the Analysis of Innovation Processes and Policies in the Forest Sector. In: Weiss G, Pettenella D, Ollonqvist P, Slee B (eds) Innovation in forestry: territorial and value chain relationships. CABI Publishing, United Kingdom, pp 10-34

Wichelns D (2007) Economic implications of microirrigation. In: Lamm FR, Ayars JE, Nakayama FS (eds) Developments in Agricultural Engineering, vol 13. Elsevier, pp 221-258. doi:10.1016/S01674137(07)80009-6

Wilson KA, Lulow M, Burger J, Fang YC, Andersen C, Olson D, O'Connell M, McBride MF (2011) Optimal restoration: accounting for space, time and uncertainty. Journal of Applied Ecology 48 (3):715-725

Wortley L, Hero JM, Howes M (2013) Evaluating Ecological Restoration Success: A Review of the Literature. Restoration Ecology 21 (5):537-543. doi:10.1111/rec.12028

Yin R, Sedjo RA (2001) Is this the age of intensive management? A study of loblolly pine on Georgia's Piedmont. Journal of Forestry 99 (12):10-17

Yousefpour R, Jacobsen JB, Thorsen BJ, Meilby H, Hanewinkel M, Oehler K (2012) A review of decisionmaking approaches to handle uncertainty and risk in adaptive forest management under climate change. Annals of Forest Science 69 (1):1-15. doi:10.1007/s13595-011-0153-4

Zentner J, Glaspy J, Schenk D (2003) Wetland and riparian woodland restoration costs. Ecological Restoration 21 (3):166-173

Zhou W (1999) Risk-based selection of forest regeneration methods. Forest Ecology and Management 115 (1):85-92 


\section{Objetivos de la tesis}

Considerando las incertidumbres en la utilización del riego aplicado al establecimiento de brinzales en las plantaciones de árboles y arbustos, los objetivos de la tesis son los siguientes:

1. Evaluar la aplicación del riego en las plantaciones de árboles y arbustos, mediante la revisión de los sistemas de micro-riego aplicados al establecimiento de los brinzales.

2. Conocer los principales ámbitos de estudio sobre el micro-riego mediante la revisión bibliográfica de la literatura científica.

3. Identificar la restricción tecnológica del micro-riego con respecto al riego convencional y determinar la posición en el mercado de los distintos sistemas de micro-riego en términos de eficiencia económica.

4. Desarrollar un modelo de decisión selvícola para proyectos de repoblación que determine qué alternativa, el riego o la reposición de planta, es más ventajosa económicamente. Analizar la sensibilidad e incertidumbre del modelo y mediante simulación, hallar las situaciones en las que el riego es más competitivo que el statu quo de la técnica actual de reposición de planta, para discutir la recomendación de su uso y proporcionar elementos de apoyo para el uso del modelo.

5. Desarrollar una herramienta informática que facilite la difusión del modelo.

6. Estimar el tamaño potencial del mercado de los cuidados culturales y de los sistemas de riego no convencionales.

7. Realizar una discusión de la evolución posible de la oferta y demanda del riego como consecuencia de una mayor disponibilidad de información. 


\section{Capítulo 2. Revisión de la tecnología del riego para el establecimiento de brinzales}

En este capítulo se presenta una revisión tecnológica de los distintos sistemas de micro-riego de brinzales. Se describe cada método indicando su fundamento de riego, sus ventajas e inconvenientes, su campo de aplicación, instalación y manejo. Los sistemas descritos se clasifican y se comparan entre sí y con los métodos tradicionales de riego. 
Tabla 1. Notación capítulo 2

\begin{tabular}{|c|c|}
\hline Símbolo & Significado \\
\hline$A$ & Superficie de infiltración; Área de un rezumador; Sección transversal de una mecha $\left\{m^{2}\right\}$ \\
\hline$c$ & Coeficiente de gasto \{adimensional\} \\
\hline$C_{a}$ & Coste de adquisición e instalación del sistema de riego $\left\{€ \cdot\right.$ unidad $\left.^{-1}\right\}$ \\
\hline$C_{b}$ & Coste de preparación del terreno y de plantación de un brinzal $\left\{€ \cdot\right.$ unidad $\left.^{-1}\right\}$ \\
\hline$e$ & Espesor de la pared de un rezumador; Longitud de mecha saturada de agua $\{\mathrm{m}\}$ \\
\hline$E_{a}$ & Eficiencia de aplicación de agua $\quad$ adimensional\} \\
\hline$E_{1}$ & Evaporación desde el recipiente del Konkom $\left\{L \cdot d i a^{-1}\right\}$ \\
\hline$E_{2}$ & Evaporación desde el suelo del Konkom $\left\{L \cdot\right.$ día$\left.^{-1}\right\}$ \\
\hline$F_{n}(\ldots)$ & Función genérica (número $n$ ) \{adimensional\} \\
\hline$f$ & Capacidad de infiltración $\left\{\mathrm{mm} \cdot \mathrm{h}^{-1}\right\}$ \\
\hline$h$ & Presión de trabajo de un emisor; altura equivalente de presión $\{m\}$ \\
\hline I & Pendiente del eje hidráulico de una mecha $\{\mathrm{m} / \mathrm{m}$; adimensional $\}$ \\
\hline$k$ & Coeficiente característico de descarga $\left\{L \cdot h^{-1} \cdot m^{-x}\right\}$ \\
\hline$k_{s}$ & Permeabilidad; Conductividad hidráulica a saturación $\left\{\mathrm{mm} \cdot \mathrm{h}^{-1}\right\}$ \\
\hline$k_{\text {so }}$ & Conductividad hidráulica a saturación la pared porosa (de un rezumador) $\left\{\mathrm{mm} \cdot \mathrm{h}^{-1}\right\}$ \\
\hline$k_{s s}$ & Conductividad hidráulica a saturación del suelo $\left\{\mathrm{mm} \cdot \mathrm{h}^{-1}\right\}$ \\
\hline$k_{s w}$ & Conductividad hidráulica a saturación de la mecha $\left\{\mathrm{mm} \cdot \mathrm{h}^{-1}\right\}$ \\
\hline & Inecuaciones lógicas que se han de verificar: $k_{s o}<k_{s s}<k_{s w}$ \\
\hline$L$ & Longitud característica de un Konkom $\{\mathrm{m}\}$ \\
\hline$n$ & Número de orden $(n=1,2,3, \ldots) \quad$ adimensional\} \\
\hline Op & $\begin{array}{l}\text { Propiedades ópticas de la botella exterior del Konkom (reflexión, transmisión y absorción de } \\
\text { la radiación electromagnética) }\left\{\mathrm{W} \cdot \mathrm{m}^{-2}\right\}\end{array}$ \\
\hline$P_{1}$ & Precipitación por goteo desde la cúpula del Konkom $\left\{L \cdot d i ́ a^{-1}\right\}$ \\
\hline$P_{2}$ & Precipitación por escorrentía en las paredes de las botellas del Konkom $\left\{L \cdot\right.$ día$\left.^{-1}\right\}$ \\
\hline$P_{3}$ & Rocío sobre la superficie del suelo en el Konkom $\left\{L \cdot\right.$ día$\left.^{-1}\right\}$ \\
\hline$P_{4}$ & Precipitaciones ocultas dentro del suelo $\left\{L \cdot d^{\prime} a^{-1}\right\}$ \\
\hline$q$ & Caudal entregado por un emisor de riego $\left\{L \cdot h^{-1} \circ L \cdot d i ́ a^{-1}\right\}$ \\
\hline$q_{1}$ & Caudal absorbido por las raíces $\left\{L \cdot d a^{-1}\right\}$ \\
\hline$q_{2}$ & Caudal perdido por evaporación $\left\{L \cdot d^{\prime} a^{-1}\right\}$ \\
\hline$q_{3}$ & Caudal perdido por percolación $\left\{L \cdot\right.$ día $\left.^{-1}\right\}$ \\
\hline$R_{S}$ & Radiación solar (irradiancia) que recibe el Konkom $\left\{W \cdot m^{-2}\right\}$ \\
\hline$S$ & Textura del suelo $\{\mathrm{mm}\}$ \\
\hline$T$ & Temperatura del aire $\{K\}$ \\
\hline$V$ & Volumen; Dosis de riego $\left\{\mathrm{L} ; \mathrm{L} \cdot \mathrm{m}^{-2} ; \mathrm{mm}\right\}$ \\
\hline$V_{a}$ & Volumen de agua aplicado por el sistema de riego $\{L\}$ \\
\hline$V_{b}$ & Volumen de agua disponible en la rizosfera para ser transpirado por los brinzales $\{L\}$ \\
\hline$x$ & Exponente de descarga del emisor $\{$ adimensional\} \\
\hline$\Delta N$ & Desnivel entre la cápsula porosa y la toma de agua $\{m\}$ \\
\hline$\psi$ & Potencial hídrico característico $\{\mathrm{m}\}$ \\
\hline
\end{tabular}

Nota: KonKom, sistema de riego mediante destilación solar 


\section{Introducción}

Los riegos de apoyo y de socorro de brinzales son muy útiles para reducir las marras por estrés hídrico en las tierras áridas, zonas áridas, subdesérticas y desérticas (Baker, 1955; Murphy, 1989; Bainbridge et al., 1995; Matorel, 1996; Navarro y Martínez, 1997; Grantz et al., 1998; Bean et al., 2004; Squeo et al., 2007). También en otros tipos de áreas críticas (Ruiz de la Torre et al., 1996) estos riegos resultan muy convenientes: así es en lugares con suelos muy someros o muy arenosos, salinos o yesosos; en zonas muy ventosas; en secarrales y solanas; en escombreras; o en huecos de minería entre otros.

El riego constituye una estrategia muy eficaz para restaurar (es decir, para oasificar) espacios degradados en donde apenas crezca vegetación. Su utilización permite ampliar el periodo de plantación o de siembra y resulta complementario a las técnicas tradicionales de recolección de agua mediante métodos de preparación del terreno (Martínez de Azagra, 1996; Prinz, 2001; Navarro et al., 2009). Frente a estas técnicas, tiene como principal ventaja su total independencia de la precipitación. Pero también tiene inconvenientes: por ejemplo, su coste y la necesidad de disponer de una fuente de agua segura y en cantidad suficiente (Del Río et al., 2013).

Aunque pueden utilizarse sistemas de riego convencionales practicados en agricultura (aspersión, goteo o gravedad en alcorques), el mercado ofrece en la actualidad métodos no convencionales: riego a través de tubos verticales hincados en el suelo, riego a través de tubos horizontales de drenaje, o a través de mechas, o mediante superficies porosas o con destiladores solares (Martínez de Azagra y Del Río, 2012). Por sus objetivos, difieren mucho de los riegos practicados en agricultura, pues no persiguen una alta producción sino el establecimiento de una vegetación leñosa: árboles y/o arbustos adaptados al lugar que -una vez arraigados- prosperen y se desarrollen de manera autónoma.

$\mathrm{Ni}$ el riego por gravedad, ni el riego por aspersión son sistemas adecuados para regar los brinzales de una repoblación forestal, ya que estas se encuentran dispersas en un amplio espacio de terreno, habitualmente con topografía irregular y con escasez de agua. En estas situaciones hay que acudir a sistemas de riego localizado para ahorrar agua. Además, riegos superficiales continuados pueden resultar perjudiciales para plantas xerofíticas, pues favorecen la proliferación de enfermedades radiculares (Bainbridge, 2007). Abundando más en el tema, al humedecer toda la superficie del suelo con el riego, pueden crecer plantas muy competidoras con el repoblado. Es por ello que el riego por pie y el riego por aspersión quedan proscritos en favor de los riegos localizados. Y dentro de éstos, los riegos subterráneos (sub-superficiales) son los más recomendables para reducir la evaporación directa y para evitar la nascencia y proliferación de plantas competidoras (Martínez de Azagra y Del Río, 2012).

En cuanto al riego por goteo estándar, Bainbridge (2007) señala que suele presentar serios inconvenientes en pleno monte: la frecuente obturación de sus emisores, el reiterado roído de los laterales de riego por parte de numerosos animales, su coste 
elevado (impulsión o depósito en altura, sistemas de filtrado, válvulas, mantenimiento...) y su alta frecuencia de aplicación (contraria a las necesidades de plantas xerófilas).

El objetivo principal de un micro-riego de brinzales es asegurar la pervivencia y apoyar el crecimiento inicial de las plantas. No se trata de riegos agrícolas en donde prevalece el criterio de maximizar el rendimiento de las cosechas. Por ello, características muy valoradas en riegos agrícolas (emisores con una gran uniformidad de fabricación, que brinden un caudal igual y constante, con buena auto-limpieza, insensibles a cambios de temperatura, con exponentes de descarga bajos, etc.) pasan a un segundo plano frente a propiedades tales como: bajo consumo de agua, alta eficiencia en su aplicación, entrega del caudal sin necesidad de presión, robustez, larga duración en plena naturaleza.

Estos sistemas de riego no convencionales también resultan interesantes en la instalación de cultivos leñosos de secano (olivar, viñedo, palmeral, algarrobar, o almendral, entre otros), en truficultura (cultivo de trufas y turmas), en paisajismo de zonas áridas y en xero-jardinería.

\section{Definición y características generales}

Los riegos de brinzales en las tierras áridas deben ser riegos localizados (junto a cada planta o semilla) y suplementarios (aportan agua, únicamente en caso necesario, para asegurar el arraigo y el establecimiento de las plantas). Son riegos deficitarios, alejados de la capacidad de campo; próximos al punto de marchitez permanente y subsuperficiales o bajo acolchado (humedecen en profundidad o superficialmente, pero bajo acolchado, mulch) para evitar la evaporación directa. Se realizan con muy baja frecuencia (por ejemplo: una vez al mes, una vez al año). Entregan el agua sin necesidad de presión (los emisores funcionan a presión nula). Son riegos temporales (se practican durante el primer año o durante unos pocos años, hasta que la vegetación introducida alcance su autonomía hídrica). Como requieren una dotación de agua muy escasa (generalmente inferior a $10 \mathrm{~m}^{3} \cdot \mathrm{ha}^{-1} \cdot \mathrm{anno}^{-1}$ ) por su aplicación localizada, por su alta eficiencia de aplicación y por los pocos puntos a irrigar por hectárea, puede hablarse de nano-riegos y de mini-dosis de aplicación.

La dosis de riego se relaciona con la capacidad de retención de agua del suelo (en el diseño agronómico del riego por gravedad y por aspersión) o con la profundidad deseada del frente húmedo a lograr (en el diseño agronómico de un riego por goteo convencional). Todo ello con el objetivo de conseguir buenas cosechas. Se persigue que la vegetación transpire todo lo que pueda y permita el clima, para maximizar así crecimientos y producciones. Pero esta estrategia dista mucho de ser acertada en brinzales xerófitos, especialistas en ahorrar agua. Un pequeño brinzal de dos savias tiene unas necesidades de 1 o 2 L de agua al mes. Con sólo 2,5 (o a lo sumo 10 L) por brinzal y temporada puede ser más que suficiente (Martínez de Azagra y Del Río, 2012).

En la instalación de brinzales con riegos, conviene distinguir entre: el riego de arraigo (o de establecimiento) que es el primer riego (nada más plantar o sembrar; o al 
poco tiempo de realizada la implantación); los micro-riegos de apoyo (o de mantenimiento) que se practican de manera programada para que los brinzales superen los periodos de sequía y que se prolongan hasta que la planta alcance su autonomía hídrica; y los Micro-riegos de socorro (o de supervivencia) que son excepcionales, imprevistos y de actuación urgente para salvar a los brinzales de una muerte segura ante una sequía extrema (Martínez de Azagra y Del Río, 2012).

El mercado ofrece una amplia gama de sistemas que merece la pena conocer y analizar. Por este motivo se hace una revisión de los distintos sistemas de micro-riego. Algunos de los métodos se conocen desde tiempo inmemorial (p. ej.: los tarros de barro enterrados o los tubos verticales hincados en el suelo) mientras que otros sistemas se han desarrollado recientemente (RIES, Konkom, Irrigasc, Waterboxx $\odot$, Moistube

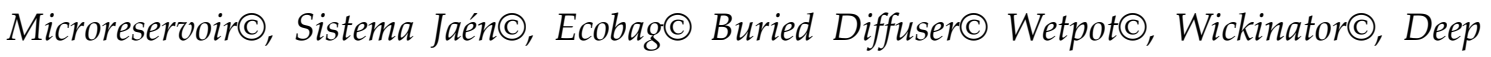
Drip $($, entre otros). Los señalados con el símbolo @ están sujetos a patente.

Se trata de un sector innovador y dinámico que incorpora numerosas patentes de reciente creación. Como tendencias de futuro previsibles dentro de este interesante sector emergente, se pueden apuntar dos: la utilización creciente de materiales plásticos permeables (de fabricación más uniforme y económica que la cerámica) y la conexión de los emisores individuales a una red de riego (opción que necesita de un número mínimo de puntos de riego por hectárea para resultar rentable y que exige algunos cambios de diseño respecto de los emisores individuales aislados).

La mayor parte de los sistemas de micro-riego de brinzales incorporan un depósito de agua (Figura 1). Son, por tanto, riegos desde una pequeña cisterna (desde un aljibe o alchub) con entrega lenta de agua por diversos procedimientos y sin necesidad de presión hidrostática. Esta cisterna debe ser rellenada periódicamente, antes o después de que se vacíe totalmente (según se desee un riego de apoyo continuo o intermitente). Algunos sistemas de micro-riego procuran que el aljibe se llene a partir de las precipitaciones verticales $\mathrm{y} / \mathrm{u}$ horizontales que acaezcan en el lugar. Poseen, en tal caso, un área de impluvio para recolectar las lluvias (Sistema Jaén ${ }^{\circledR}$ ) o una superficie captadora de lluvias y rocíos (Waterboxx ${ }^{\circledR}$ ) o un atrapanieblas para ordeñar las nieblas (Acosta, 2003; Estrela et al., 2009; Santamarta y Seijas, 2010; Valiente et al., 2011). De esta manera aumentan las posibles fuentes de agua, pudiendo llegar a ser sistemas autónomos en ciertos lugares, de manera que no requieran ser rellenados periódicamente.

Atendiendo al fundamento de entrega de agua de cada sistema pueden distinguirse cuatro grupos: a) el riego directo en profundidad (regido por la infiltración), b) el riego a través de paredes porosas (regido por la ley de Darcy), c) el riego a través de cordeles o de fieltros y d) el riego mediante destiladores solares (Tabla 2). 


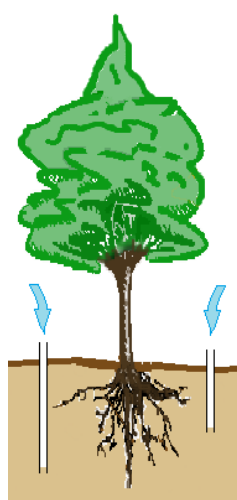

a)

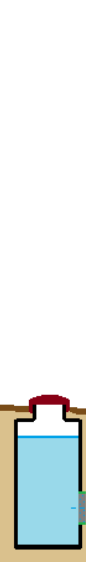

b)

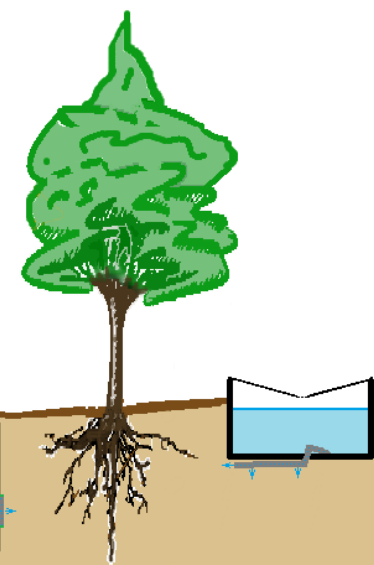

c)

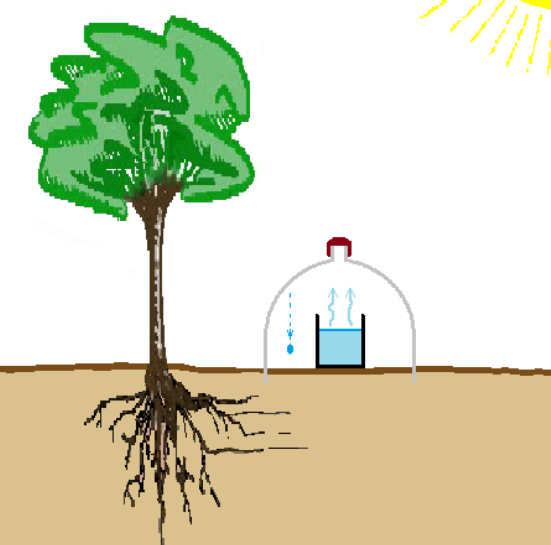

d)

Figura 1. Sistemas de entrega de agua: a) Infiltración directa; b) Paredes porosas; c) Mecha de riego; d) Destilador solar

La ecuación característica de un emisor convencional (bien se trate de un cañón de riego, aspersor, microaspersor o gotero) depende de la presión (h, en m) existente en la red de riego (Karmeli y Keller, 1975).

$$
q=F_{1}(h)=k \cdot h^{x}
$$

siendo $q$ el caudal emitido $\left\{e n \mathrm{~L} \cdot \mathrm{h}^{-1}\right\}, F_{1}(\ldots)$ una función (la ecuación característica del emisor), $h$ la presión de trabajo del emisor $\{\mathrm{m}\}, k$ su coeficiente de descarga característico $\left\{\mathrm{L} \cdot \mathrm{h}^{-1} \cdot \mathrm{m}^{-x}\right\}$ y $x$ el exponente de descarga del emisor \{adimensional; con valores comprendidos entre $0 \leq x \leq 1$ ).

Por el contrario, la ecuación característica que determina el caudal de riego entregado por los emisores que se trata en este capítulo no depende de una presión de trabajo. Son emisores que pueden funcionar a presión relativa nula; esto es: $h=0 \mathrm{~m}$.

Tabla 2. Ecuaciones características de emisores no convencionales

\begin{tabular}{lll}
\hline Sistema de riego & Ecuación característica & $\begin{array}{l}\text { Fundamentos de entrega } \\
\text { de agua }\end{array}$ \\
\hline $\begin{array}{l}\text { Riego por aspersión, microaspersión } \\
\text { o goteo }\end{array}$ & $\boldsymbol{q}=\boldsymbol{F}_{\mathbf{1}}(\boldsymbol{h})=\boldsymbol{k} \cdot \boldsymbol{h}^{\boldsymbol{x}}$ & Presión hidrostática \\
$\begin{array}{l}\text { Riegos por infiltración directa en } \\
\text { profundidad }\end{array}$ & $\boldsymbol{q}=\boldsymbol{F}_{\mathbf{2}}(\boldsymbol{f}, \boldsymbol{A})=\boldsymbol{c} \cdot \boldsymbol{f} \cdot \boldsymbol{A}$ & Infiltración \\
$\begin{array}{l}\text { Riego a través de paredes porosas } \\
\text { (rezumadores) }\end{array}$ & $\boldsymbol{q}=\boldsymbol{F}_{\mathbf{3}}\left(\boldsymbol{A}, \boldsymbol{e}, \boldsymbol{k}_{\boldsymbol{s o}}, \boldsymbol{\psi}\right)$ & $\begin{array}{l}\text { Diferencia de potencial } \\
\text { hídrico }\end{array}$ \\
$\begin{array}{l}\text { Riego a través de mechas } \\
\text { Riego a través de destiladores solares }\end{array}$ & $\boldsymbol{q}=\boldsymbol{F}_{\mathbf{4}}\left(\boldsymbol{A}, \boldsymbol{e}, \boldsymbol{k}_{\boldsymbol{s} \boldsymbol{w}}, \boldsymbol{\psi}, \boldsymbol{I}, \boldsymbol{R}_{\boldsymbol{S}}, \boldsymbol{O} \boldsymbol{p}, \boldsymbol{T}, \boldsymbol{S}\right)$ & $\begin{array}{l}\text { Diferencia de potencial } \\
\text { hídrico y capilaridad }\end{array}$ \\
\hline
\end{tabular}

Nota: En la tabla 1 se puede consultar el significado de los símbolos utilizados en este capítulo. 


\section{Descripción de los distintos sistemas}

\subsection{Infiltración directa en profundidad}

En los riegos por infiltración directa, el caudal de riego depende de la capacidad de infiltración del suelo $\left(f\right.$, en $\left.\mathrm{mm} \cdot \mathrm{h}^{-1}\right)$ y de la superficie de contacto $\left(A\right.$, en $\left.\mathrm{m}^{2}\right)$ entre el sistema de riego y el suelo. Aunque no se realice en superficie, el riego se aplica directamente sobre el suelo de manera que su tasa de entrega $(q)$ resulta directamente proporcional a la capacidad de infiltración del suelo, al igual que ocurre en el riego por planta:

$$
q=F_{2}(f, A)=c \cdot f \cdot A
$$

siendo $c$ el coeficiente de gasto \{adimensional\} que ajusta los valores teóricos a los valores reales.

\subsubsection{Micro-riego por medio de tubos verticales}

Se trata de un sistema de riego localizado y subterráneo muy efectivo (Allué y Navarro, 1970; Bainbridge, 2002; Sánchez et al., 2004) que se realiza a través de un pequeño tubo vertical de diámetro reducido ( 5 a $30 \mathrm{~mm}$ ), enterrado unos 25 a $50 \mathrm{~cm}$ y que asoma 2 o $3 \mathrm{~cm}$. Gracias al tubo vertical, al regar el agua se sitúa en profundidad junto a las raíces del brinzal. De esta manera se evitan áreas húmedas en superficie y se aumenta la eficiencia en la aplicación de la escasa agua (Figura 2). Se utilizan tubos plásticos de PVC, de PE o tuberías porosas. También pueden emplearse tallos huecos de plantas locales (caña, bambú, etc.). En el mercado existen tubos plásticos específicos diseñados para esta finalidad, como los deep pipe watering stakes que, por su forma y material (cabeza reforzada, acabados en punta y fabricados en plástico robusto ABS), pueden ser introducidos en el suelo directamente mediante martillo.

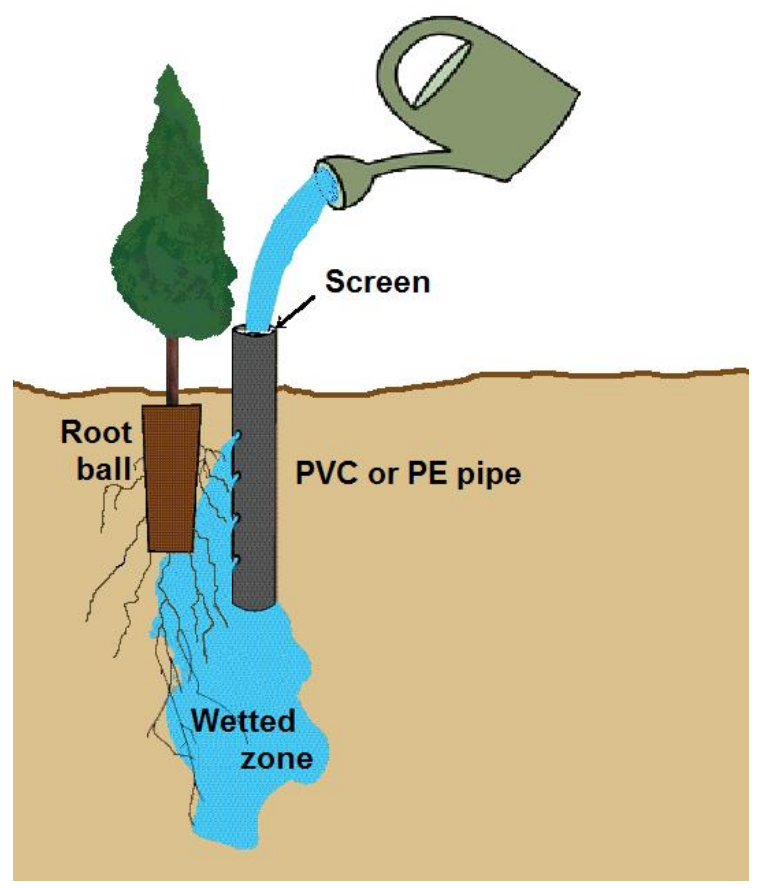

Figura 2. Riego subterráneo mediante un tubo vertical 
El riego puede hacerse de manera manual e individualizada (yendo tubo a tubo con una regadera) pero también se puede extender una red de ramales de riego con emisores que abastezcan a cada tubo vertical. Este último sistema se encuadra dentro de los riegos por goteo subterráneo, poseyendo una ventaja sustancial (Martínez y Reca, 2014): ni las raíces ni el propio suelo pueden interferir en el caudal emitido por los goteros.

Los tubos verticales suponen un método sencillo, barato y eficaz de riego localizado que promueve el crecimiento en profundidad de las raíces de los brinzales (Bainbridge, 2006a). Pero el sistema presenta algunas limitaciones de aplicación en suelos con texturas extremas. En los muy arcillosos la aplicación de una dosis de riego puede demorarse muchísimo (por ser muy lenta la velocidad de infiltración). Sólo si se dimensiona el tubo para poder recibir la dosis de riego proyectada sin tener que esperar a que el agua se infiltre, el riego resultará operativo. Por el otro extremo, los terrenos muy arenosos tienen tan baja capacidad de retención de agua que el agua aportada tiende a percolar, a escapar de la rizosfera del brinzal, con lo que se desaprovecha. Una solución frente a este problema consiste en aplicar geles de irrigación en vez de agua (Driwater ${ }^{\circledR}$, Envirogrower $^{\circledR}$, etc.) pero se trata de una solución cara, más propia de xerojardinería y arboricultura que de restauración forestal.

Existen otros sistemas de riego subterráneo a través de tubos verticales. El denominado buried stones pocket (Chahbani, 1992, 2004) consiste en abrir una o varias zanjas de profundidad adecuada $(0,5$ a $1 \mathrm{~m})$ cerca del árbol adulto o del brinzal a regar, nivelar su fondo, rellenarlas parcialmente con una capa de piedras, cubrir las piedras con un plástico y volver a cerrar las zanjas con la tierra extraída, incluyendo uno o dos tubos verticales que conecten la superficie del terreno con la capa de piedras. De esta manera, la dosis de riego puede aplicarse con rapidez aun en terrenos que posean una baja capacidad de infiltración. El agua difunde horizontalmente y a la profundidad deseada por los pockets of buried stones enterrados. Se ha ensayado sobretodo en olivares de Túnez. Requiere lugares con suelos pedregosos pero profundos.

Conceptualmente similar, aunque bastante más sofisticado es el buried diffuser ${ }^{\circledR}$ (Chahbani, 2012). La capa de piedras se sustituye aquí por un difusor de poliuretano cuya base es porosa y que entrega agua sin necesidad de presión (Figura 3). Se está ensayando con numerosos árboles frutales: olivos, palmeras datileras, granados, almendros, manzanos, perales o parras, entre otros. 


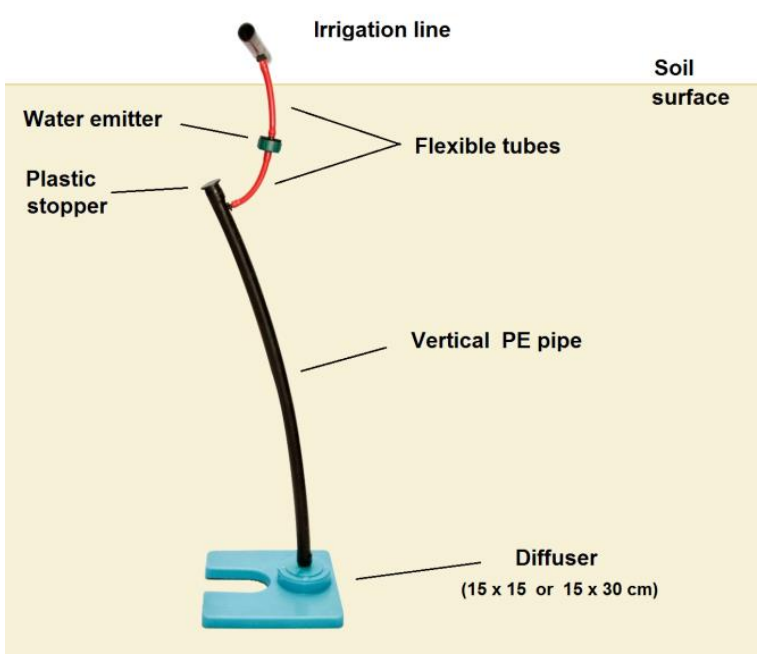

Figura 3. Esquema con las piezas y conexiones de un Buried diffuser ${ }^{\circledR}$

El Irrigasc (Gasc, 2002; Mathieu, 2006) es un método desarrollado en Senegal para plantar árboles y arbustos (mangos, anacardos, naranjos, limoneros, eucaliptos, papayas, mandiocas, entre otros). Consiste en un plástico agujereado de polipropileno (PP) con forma de calcetín que termina en punta y que posee una base rígida de polietileno (PEHD) en su otro extremo con una capacidad aproximada de un litro (Figura 4). Se inserta en el suelo junto al brinzal, previa apertura de un hoyo de igual diámetro (unos $10 \mathrm{~cm}$ ) y se rellena con el mismo suelo extraído o con un suelo mejorado (con abono NPK, gallinaza, etc.) hasta alcanzar la base rígida. Cada pocos días se aplica un riego a través del Irrigasc vertiendo un litro de agua en el vaso negro superior. Estos riegos se prolongan durante meses hasta que el brinzal alcanza su autonomía hídrica.

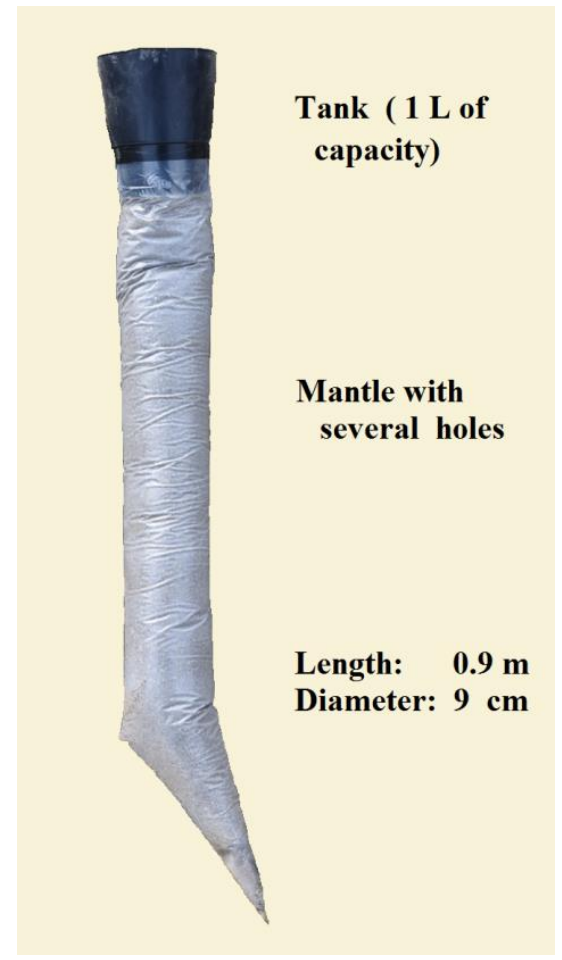

Figura 4. El saco permeable Irrigasc 


\subsubsection{Riego mediante drenes horizontales}

Este sistema recuerda al método buried stones pocket con la diferencia de que utiliza las tuberías corrugadas de PVC, usadas habitualmente para drenaje (Bainbridge, 2007). Estas tuberías incluyen pequeños taladros o ranuras distribuidos a lo largo y ancho de toda su extensión (Figura 5) por las que drena o se infiltra el agua. Se entierran a la profundidad deseada (unos 30 a $50 \mathrm{~cm}$, o incluso más). A intervalos apropiados (entre 15 y $30 \mathrm{~m}$, dependiendo del tipo de suelo y de su pendiente) hay que instalar un tubo vertical (una boca de llenado, que puede ser el mismo extremo de la tubería corrugada). El llenado de la tubería suele realizarse mediante camiones cisterna (aguadores), con cubas remolcadas por tractor, o con carrocetas contra incendios (que resultan ideales para cualquier riego de socorro o de apoyo). Para poder dosificar bien interesa incluir un contador en el circuito hidráulico. Se consigue así un riego localizado, subterráneo, sencillo y barato para alineaciones de plantas, por ejemplo: para implantar una barrera cortavientos en lugares áridos o hiperáridos. Como sistema de riego para la supervivencia y apoyo a repoblaciones forestales extensas y en lugares abruptos no parece un método indicado. Tampoco lo es en terrenos arenosos profundos por problemas de percolación.

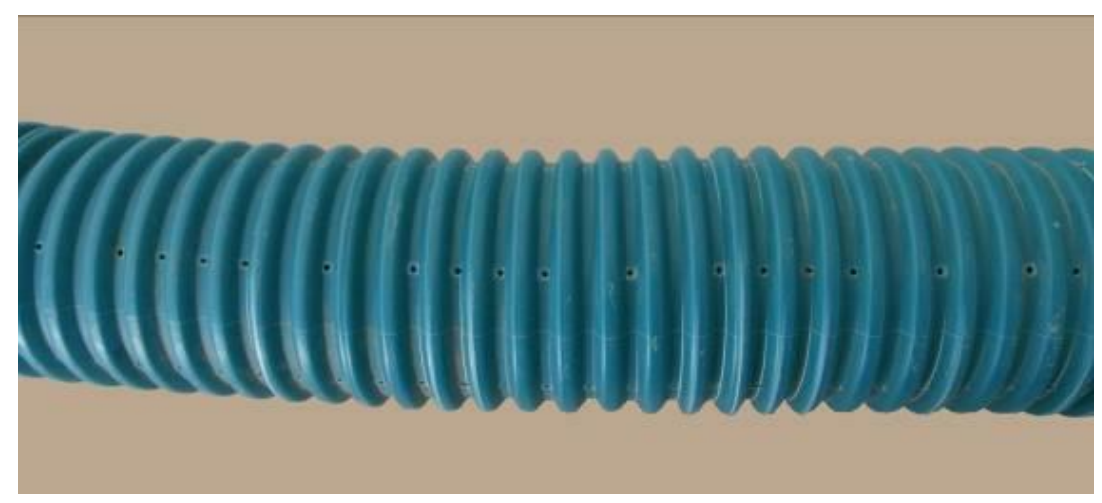

Figura 5. Tubería de drenaje de PVC corrugado

\subsection{Riego a través de paredes porosas (rezumadores)}

Un rezumador es una pared rígida y porosa saturada de agua que resuda lentamente, en régimen laminar, regando de forma localizada, sin necesidad de presión en la red. El aporte de agua se produce conforme a la ley de Darcy. Su ecuación característica es función de cuatro parámetros (Martínez de Azagra y Del Río, 2015): el área del rezumador $\left(A\right.$, en $\left.\mathrm{m}^{2}\right)$, el espesor de su pared $(e$, en $\mathrm{m})$, su permeabilidad $\left(k_{s o}\right.$, en $\mathrm{mm} \cdot \mathrm{h}^{-1}$ ) y un potencial hídrico característico ( $\psi$, en $\mathrm{m}$ ), que representa la diferencia de potencial hídrico existente a un lado y otro del rezumador. Luego:

$$
q=F_{3}\left(A, e, k_{s o}, \psi\right)=c \cdot \frac{k_{s o}}{e} \cdot \psi \cdot A
$$

Los rezumadores pueden ser de barro cocido o de materiales plásticos (Figura 6). Su superficie rezumante $(A)$ puede ocupar toda el área exterior del recipiente o sólo con una parte del mismo. 
El riego por succión (Olguín, 1975) a través de rezumadores tiene una tasa de entrega que depende de la sequedad del suelo ( $\psi$, ecuación [3]). Esta autorregulación permite un gran ahorro de agua (Rendón et al., 1981; Abu-Zreig et al., 2006; Vargas, 2012; Vasudevan et al., 2014) pero conduce a dosis de riego variables de unos lugares a otros dentro de la misma repoblación (lo que poco afecta a la finalidad última de un microriego de apoyo de brinzales xerófitos). A mayores y si el contacto entre el emisor y el suelo no es íntimo, el caudal puede ser bastante menor (por rezumar el emisor al aire) (Martínez de Azagra y Del Río, 2015). Otro hecho constatado es que las raíces terminan por tapizar el rezumador con una tupido paño (hidrotropismo), lo que también modifica el caudal entregado al hacerlo el potencial hídrico $(\psi)$.

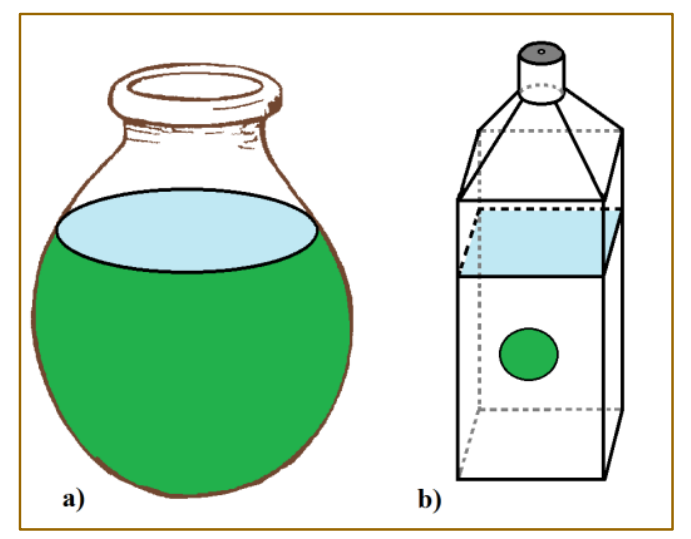

Figura 6. a) Recipiente de barro cocido utilizado en el riego por succión tradicional. Toda su superficie rezuma. b) Botella impermeable de plástico con un único rezumador circular

La pared de un rezumador es sensible a las obturaciones pero ello no interrumpe su resudado, sino que lo disminuye, pues el agua dispone de muchos recorridos hidráulicos alternativos cuando el medio poroso es amplio ( $A$ grande). Lógicamente y si se utilizan aguas turbias o con muchos microorganismos, la reducción de $k_{s o}$ con el paso de los meses es ostensible. A su vez y en climas con fuertes heladas, éstas pueden alterar la porosidad del rezumador de un año al siguiente, provocando microgrietas que aumentan $k_{s o}$.

\subsubsection{Riego mediante tarros de barro enterrados}

Es un sistema de riego muy antiguo a la vez que muy actual: antiguo porque el hombre lo lleva practicando desde hace más de dos mil años (Bainbridge, 2001; Tilló, 2006; UNEP, 1997); actual por su alta eficiencia y renovado interés (Abu-Zreig y Atoum, 2004; Qiaosheng et al., 2007; Siyal y Skaggs, 2009; Siyal et al., 2009; Setiawan et al., 2009; Memon et al., 2010; Gopinath y Veeravalli, 2011; Abu-Zreig et al., 2012).

En el libro de Fan Shengzi (redactado en Shandong, China, en el siglo I antes de Cristo) se describe este sistema para cultivar melones (Sheng-Han, 1974). Tilló (2006) refiere que los fenicios enterraban vasijas de arcilla porosa al pie de los olivos y que las rellenaban con agua a intervalos regulares. También los romanos parecen haber conocido y difundido este sistema de irrigación (UNEP, 1997). Ello puede explicar el hecho de que en la cultura rural mediterránea el sistema sea bien conocido y que se 
aplique para instalar árboles frutales de secano (olivos, almendros, algarrobos, jerbos, etc.). En el sector forestal español también se aplica el método y recibe el expresivo nombre de repoblaciones «con biberón» (Serrada et al., 2005). En otros países, tan distantes como Pakistán, Cuba, India o Siria el sector forestal también acude al método ante situaciones de repoblación difícil, como describen Shiek y Shah (1983), Ortega et al., (1986), Jethwa (1993) o Ghaibeh (2001) respectivamente.

Los primeros estudios sistemáticos sobre riegos a través de vasijas que hemos localizado se deben a Mondal (1974a, 1974b) en Karnal (India) y a Olguín (1975, 1977) en Chapingo y Ciudad Obregón (México). Mondal (1974a, 1974b) utiliza vasijas aisladas (para cultivar Citrullus vulgaris, Cumis melo, Cucurbita pepo y Lagenaria leucantha) mientras que Olguín establece un riego con cápsulas cerámicas, elevadas respecto de la toma $(\Delta N)$ e interconectadas mediante tuberías (Figura 7). Ensaya con éxito el cultivo de frijoles, habas y maíz (Figura 8).

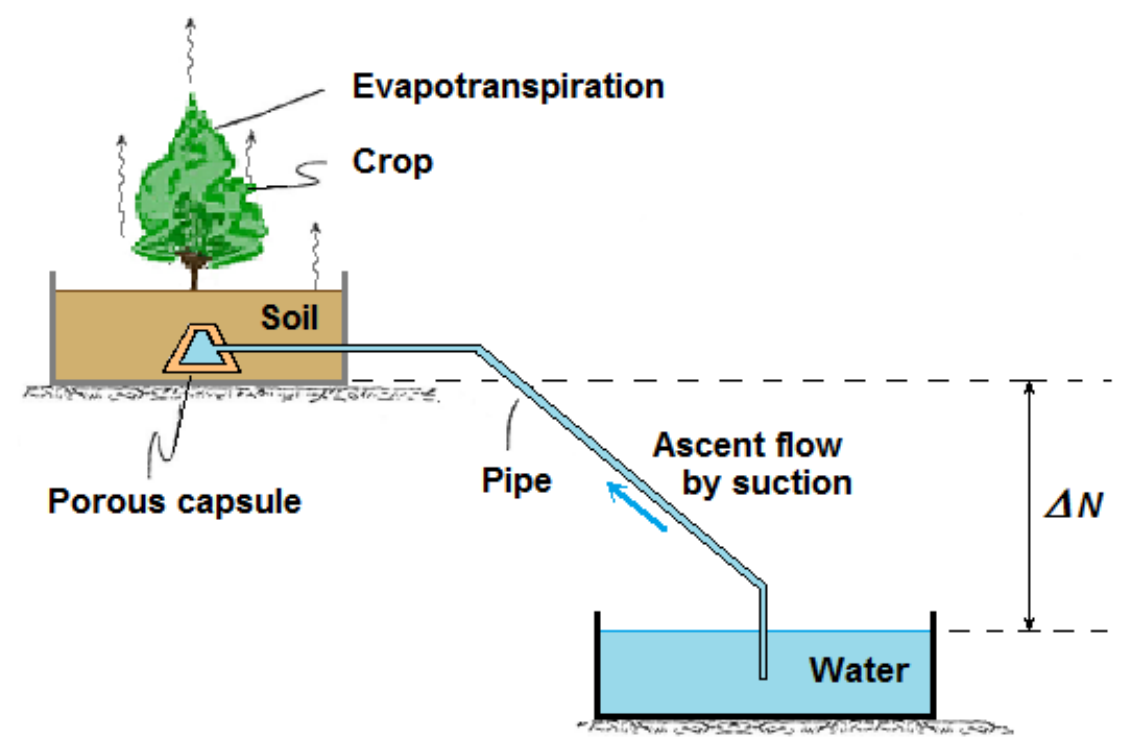

Figura 7. Esquema del riego por succión ideado por Olguín (1975). Reelaborado a partir de un dibujo original del autor 


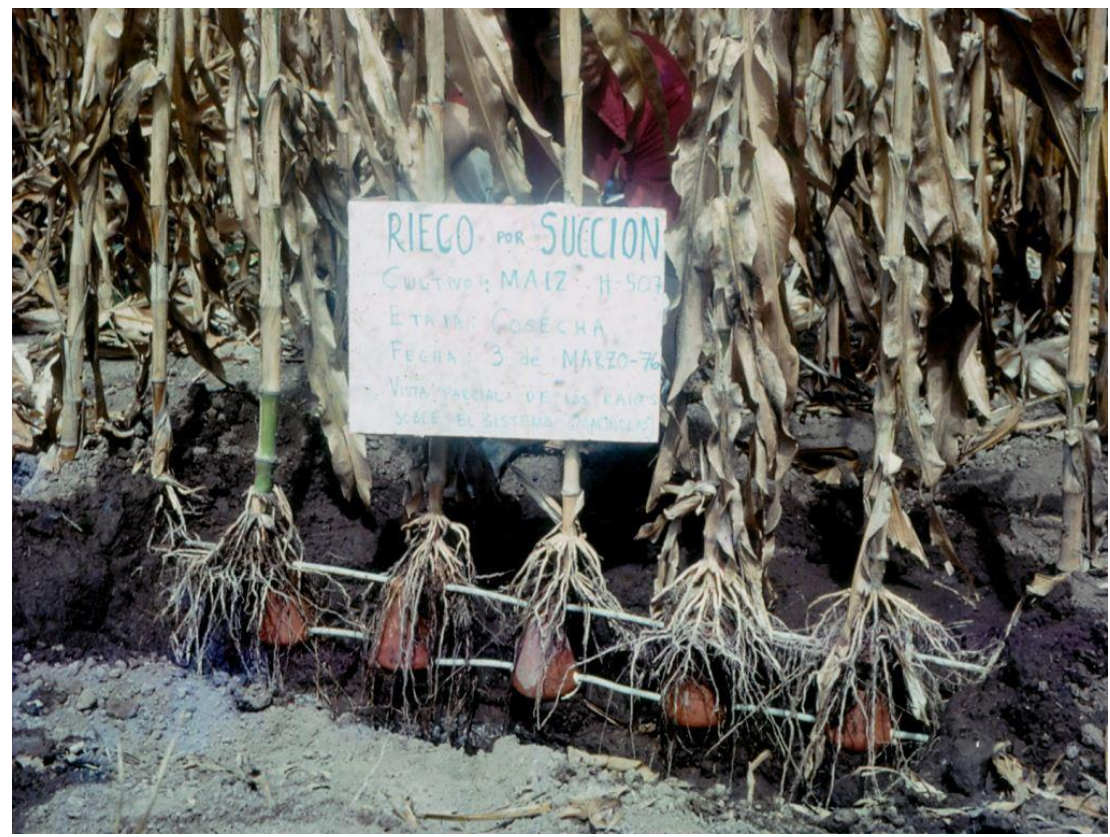

Figura 8. Cultivo de maíz con riego por succión mediante cápsulas porosas interconectadas con una tubería de plástico de $4 \mathrm{~mm}$ de diámetro. Foto de los primeros ensayos de campo, facilitada por Carlos Olguín Palacios

Después de estos primeros trabajos se han sucedido numerosas investigaciones sobre la materia que escapan de los objetivos de esta revisión. Destacan las publicaciones de Stein (1994, 1995, 1996, 1997a, b; 1998) en el ámbito agrícola y de Bainbridge (2001, 2002, 2007) en el ámbito ecológico y forestal.

El llenado de las vasijas se suele realizar de forma manual, pero también se han ideado sistemas para su llenado automático a través de laterales de riego y válvulas de flotador (Silva et al., 1982; Stein, 1998). La utilización de cápsulas porosas cerradas en sustitución de vasijas abiertas elimina el riesgo de rebosadura durante el llenado. Otra posibilidad consiste en utilizar tuberías porosas de barro cocido (Ashrafi et al., 2002; Qiaosheng et al., 2007; Igbadun y Barnabas, 2013), sistema que permite irrigar plantaciones lineales cortavientos.

Para riegos de brinzales xerófitos, enterrando un pequeño recipiente de barro cocido (de entre 0,5 y $3 \mathrm{~L}$ de capacidad) junto a cada planta y llenándolo de agua periódicamente, se asegura su implantación y crecimiento, aún en los años y lugares más adversos. La característica primordial del recipiente es su conductividad hidráulica a saturación $\left(k_{s}\right)$ (Abu-Zreig y Atoum, 2004), parámetro que varía mucho según el tipo de arcilla usada y los aditivos incorporados (arena, sal u otros), la temperatura y el tiempo de cocción, y el acabado de las superficies de la vasija. Tanta dispersión, que no es predecible a priori al iniciar el proceso de fabricación en un alfar, aconseja realizar ensayos previos antes de instalar un sistema extenso de riego mediante vasijas porosas (Stein, 1998). Para un recipiente de 2 L de capacidad, un tiempo de vaciado de tres a cuatro semanas resulta adecuado y permite dilatar el tiempo convenientemente entre llenados sucesivos (Martínez de Azagra y Del Río, 2012). En cuanto a la forma, los mejores potes son altos y de boca pequeña (para que sea más fácil cerrarlos, pero que se 
dejen llenar sin derramar el agua) y de cuello largo con base panzuda (para que rieguen en profundidad). La posibilidad de barnizar el cuello con el fin de mejorar la eficiencia del riego también puede ser contemplada. Un diseño de este tipo es el del Wetpot $^{\circledR}$, sistema ideado en principio para pequeños huertos y jardines en zona árida.

\subsubsection{Botellas de plástico poroso}

La posibilidad de regar arboles recién plantados por medio de botellas de plástico enterradas y convenientemente modificadas, ha sido ensayada con éxito en Perú por Matorel (1996, 1998, 2006). Su sistema artesanal, denominado RIES (Reservorios Individuales de Exudación Subterránea) consiste en conectar varias botellas reutilizadas por su parte inferior mediante pequeñas mangueritas plásticas (para permitir su llenado y vaciado conjunto por vasos comunicantes) e instalar rezumadores (filtros de fibra plástica convenientemente calibrados para que descarguen el agua contenida en aproximadamente 25 a 30 días). El paquete de botellas (con una capacidad comprendida entre 3 y 12 L) va enterrado junto a la zona radicular de la planta quedando sólo los tapones visibles (Figura 9).

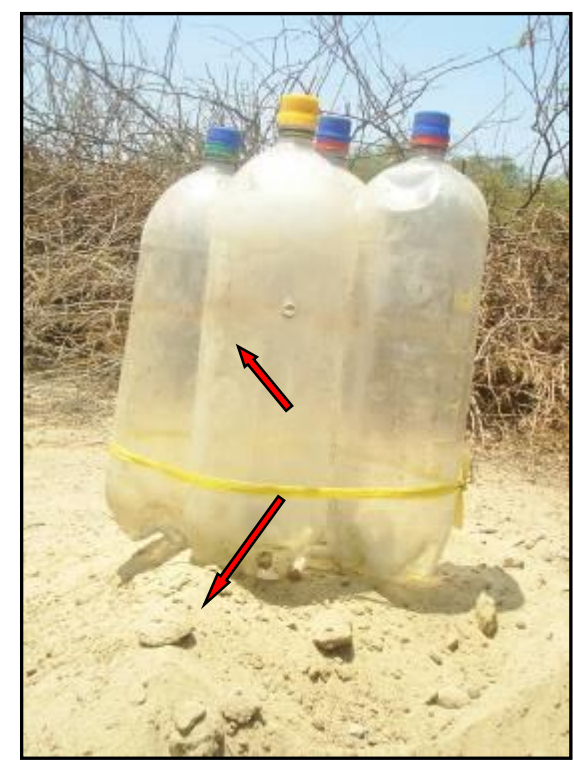

Figura 9. Reservorio individual de exudación subterránea (RIES) con los dos rezumadores (flechas rojas), cedidas por Mario Matorel García

Se han realizado plantaciones forestales en el departamento de Piura (Perú) con algarrobos (Prosopis pallida), sapotes (Capparis angulata), charanes (Caesalpinea paipai) y hualtacos (Loxopterigium huasango). También se han realizado plantaciones frutales de tamarindos (Tamarindus indica), mangos (Mangifera indica) y mango-ciruelos (Spondias cytherea) en la comarca, utilizando rezumadores mayores para aplicar riegos más copiosos. Las botellas de plástico también han servido para confeccionar tubos protectores con los que proteger a los brinzales de la herbivoría, del viento y de la desecación (Figura 10). 


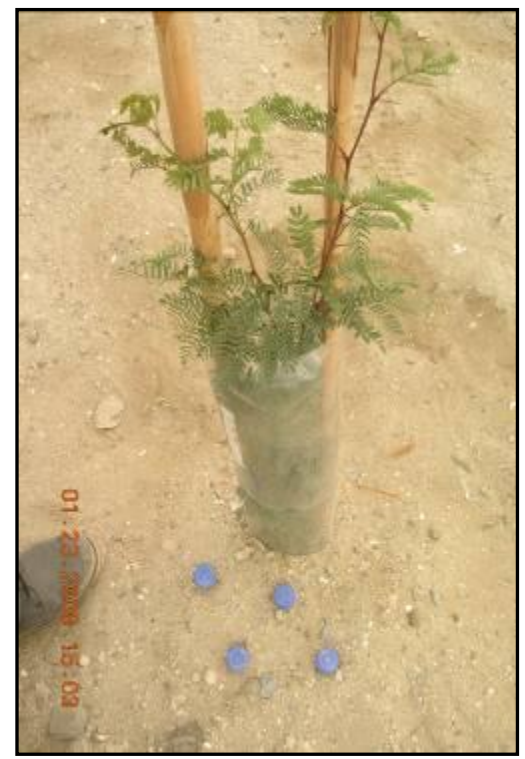

Figura 10. Tubo protector artesanal y tapones de las cuatro botellas de un reservorio enterrado, cedidas por Mario Matorel García

Las botellas de plástico se pueden conectar a un ramal de riego con el fin de poder llenarlas de manera conjunta en vez de individualmente. Desde 2011 una empresa australiana comercializa botellas porosas (Moistube Microreservoir ${ }^{\circledR}$ ) de 1,5 o de 3 L de capacidad, ideadas para su inclusión en redes de riego. Estas botellas, al no ser rígidas, precisan de una ligera presión de trabajo $(h \geq 2 \mathrm{~m})$ para permanecer hinchadas en contacto con el suelo e irrigarlo.

\subsection{Riego a través de mechas}

Una mecha de riego es un cordel (una cuerda) de diámetro y longitud variables formado por fibras de un tejido sintético (nylon, poliéster, acrílico, ...) o de un tejido natural (algodón, cáñamo, yute...) que rezuma, transmite y entrega agua lentamente. Su ecuación característica $\left(F_{4}\right)$ incorpora un parámetro más que los rezumadores:

$$
q=F_{4}\left(A, e, k_{s w}, \psi, I\right)
$$

en donde $A$ es la sección transversal de la mecha $\left\{\mathrm{m}^{2}\right\} ; e$ es la longitud de mecha que está saturada $\{m\}$, quedando otro tramo de mecha sin saturar en donde el flujo se rige por la ley de Buckingham - Darcy; $k_{s w}$ es la conductividad hidráulica a saturación de la mecha $\left\{\mathrm{mm} \cdot \mathrm{h}^{-1}\right\} ; \psi$ es un potencial hídrico característico $\{\mathrm{m}) ;$ e $I$ es la pendiente fen $\mathrm{m} / \mathrm{m}$; adimensional $\}$ de la mecha, que puede ser descendente $\{-\}$, ascendente $\{+\}$, o mixta $\{+,-\}$ (Figura 11). Esta pendiente también regula la tasa de entrega $(q)$, sobre todo si es ascendente. 


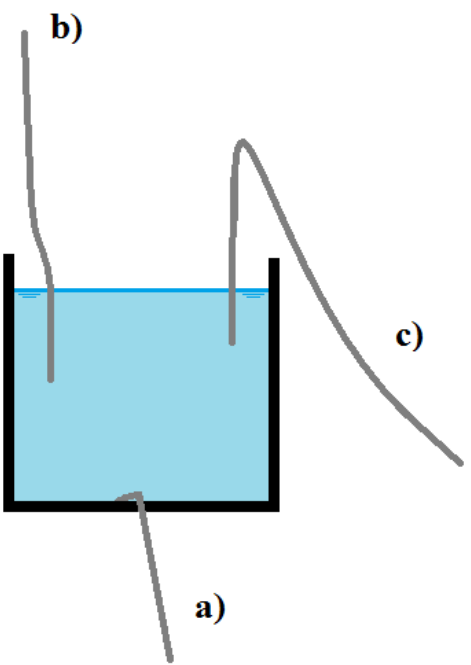

Figura 11. Pendiente (I) del eje hidráulico de tres mechas: a) Descendente (p. ej.: en el Waterboxx $\left(\right.$ ); b) Ascendente (p. ej.: en el Wickinator ${ }^{\circledR}$ ); c) Mixta sifón capilar (p. ej.: en el riego casero de tiestos)

Al igual que los rezumadores, las mechas tienen una tasa de entrega de agua que depende de la sequedad del suelo (Ortmann, 1991). Su capacidad de irrigar de manera subterránea y autorregulada les otorga un gran interés (Wesonga et al., 2014). Las mechas son baratas y fáciles de recambiar. Las elaboradas con fibras sintéticas son muy duraderas. Su límite de utilización suele producirse por su obturación parcial o total, pues actúan como filtros.

El sistema de riego a través de mechas es el método tradicional casero más empleado para regar tiestos de manera autónoma durante algunas semanas de ausencia en el hogar. La manera más sencilla de preparar este sistema consiste en poner una botella junto a cada tiesto y conectarla al cepellón a través de un sifón cordel (Figura 12). Pero existen otras muchas disposiciones posibles (Ortmann, 1991) en las que la mecha realiza distintos recorridos (descendente, ascendente y/o mixto). A su vez, el mercado de la jardinería de interior ofrece una amplia gama de productos para resolver esta situación: conos cerámicos irrigadores, hidrojardineras, goteros, etcétera. 


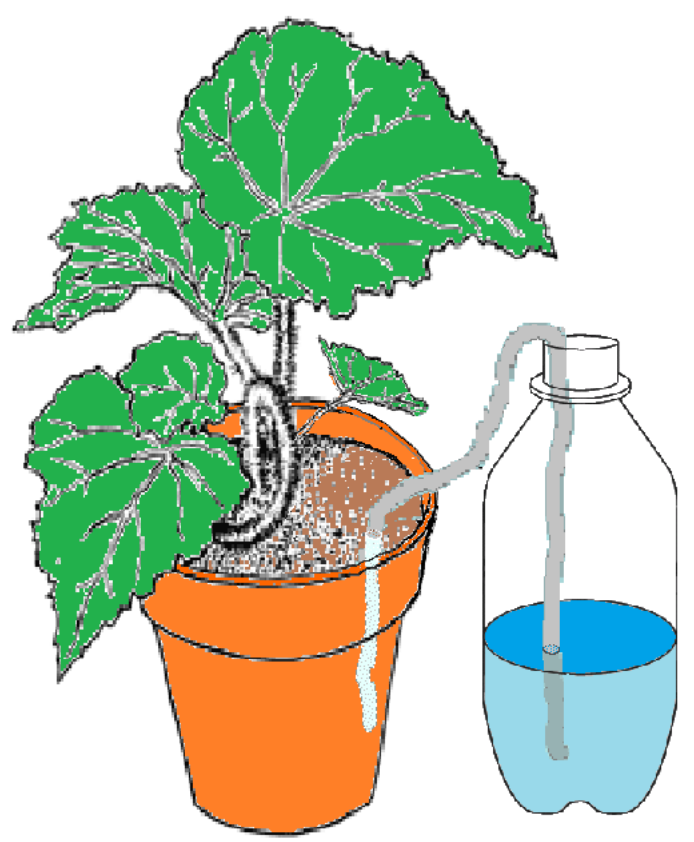

Figura 12. Riego casero con mecha

Para el micro-riego de brinzales, Bainbridge (2002, 2006b, 2007, 2012) ha ensayado distintas disposiciones. Recomienda alimentar a la planta por gravedad (mechas descendentes) y plantea la posibilidad de incorporar una pinza para poder regular el flujo de caudal a conveniencia. En su objetivo por conseguir sistemas hipereficientes de riego envuelve la mecha en un tubo para que no pueda evaporarse agua durante el recorrido aéreo del cordel.

Con una botella PET (politereftalato de etileno) reutilizada y un cordel de un diámetro algo mayor que el taladro practicado en el tapón de la botella (p. ej.: 8 y 7 mm, respectivamente), se puede preparar un dispositivo sencillo y económico para dar riegos de apoyo a los brinzales durante el primer verano (Martín et al., 2014). La parte comprimida del cordel en el estrechamiento del tapón actúa como un rezumador que entrega el agua al resto de la mecha, que es la encargada de transmitir el agua a profundidad, ayudando al arraigo de los arbolitos. En algunas comarcas de India se combina el método de irrigación a través de vasijas de barro con la inclusión de mechas (Marigowda, 1974). De este modo se consigue entregar el agua directamente a las raíces y se incrementa la penetración del agua en el suelo. En los estados de Karnataka y Kerala se aplica este riego combinado durante los dos o tres primeros años en la implantación de cocoteros y palmeras de betel (Cocos nucifera y Areca catechu, respectivamente) (James, 2006; Prabu, 2008) (Figura 13). 


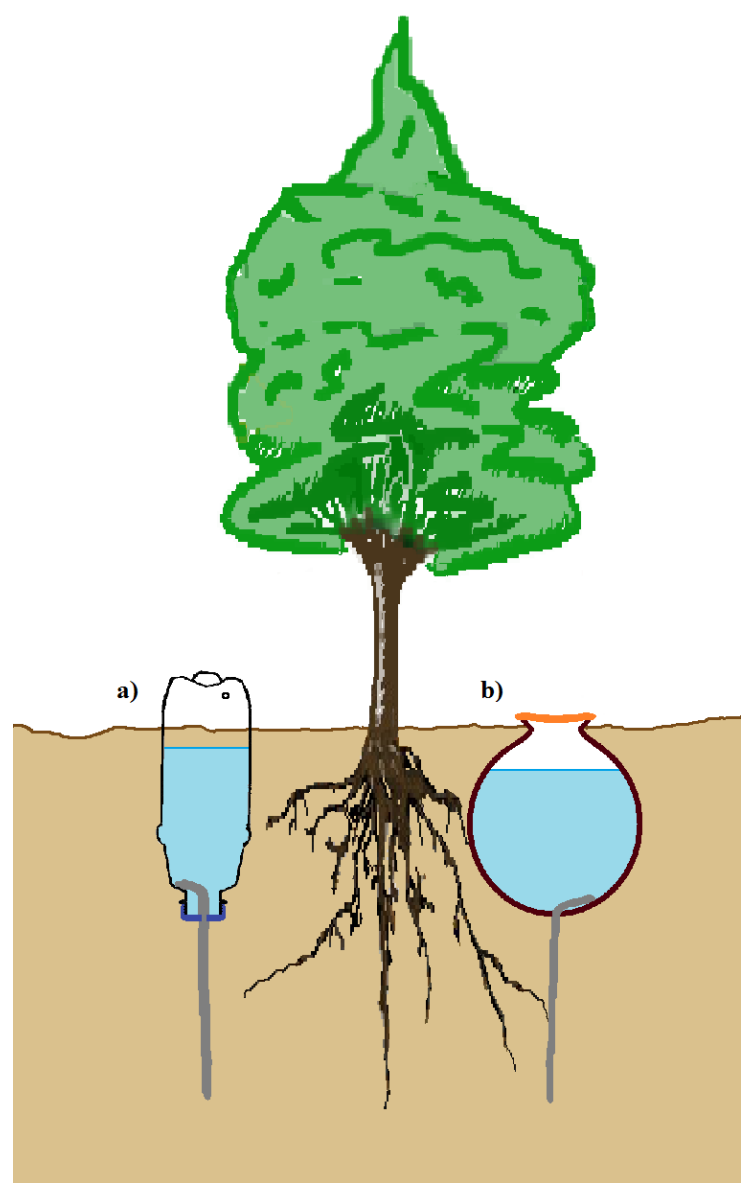

Figura 13. Recipientes con mecha: a) Botella PET; b) Vasija de barro

El mercado del micro-riego de brinzales ofrece en la actualidad dos productos que irrigan lentamente a través de mechas o de fieltros: el Eco Bag ${ }^{\circledR}$ y el Waterboxx ${ }^{\circledR}$. El primer sistema, desarrollado por una empresa australiana en 2005, consiste en un depósito plástico con forma que recuerda a una almohadilla cervical (Figura 14). Tiene una capacidad para $20 \mathrm{~L}$, ocupa $0,6 \times 0,6 \mathrm{~m}$ alrededor de la planta y entrega el agua por medio de un fieltro a una tasa aproximada de $1 \mathrm{~L} \cdot d i ́ a^{-1}$, lo que exige su relleno cada tres o cuatro semanas, si se desea un riego sin interrupciones. Esta bolsa se instala en superficie, pero puede ocultarse fácilmente con paja, astillas de madera, o con un poco de tierra (dejando visible el tapón de relleno). Está siendo utilizada para la implantación de brinzales tanto en xero-jardinería como en repoblación forestal. 


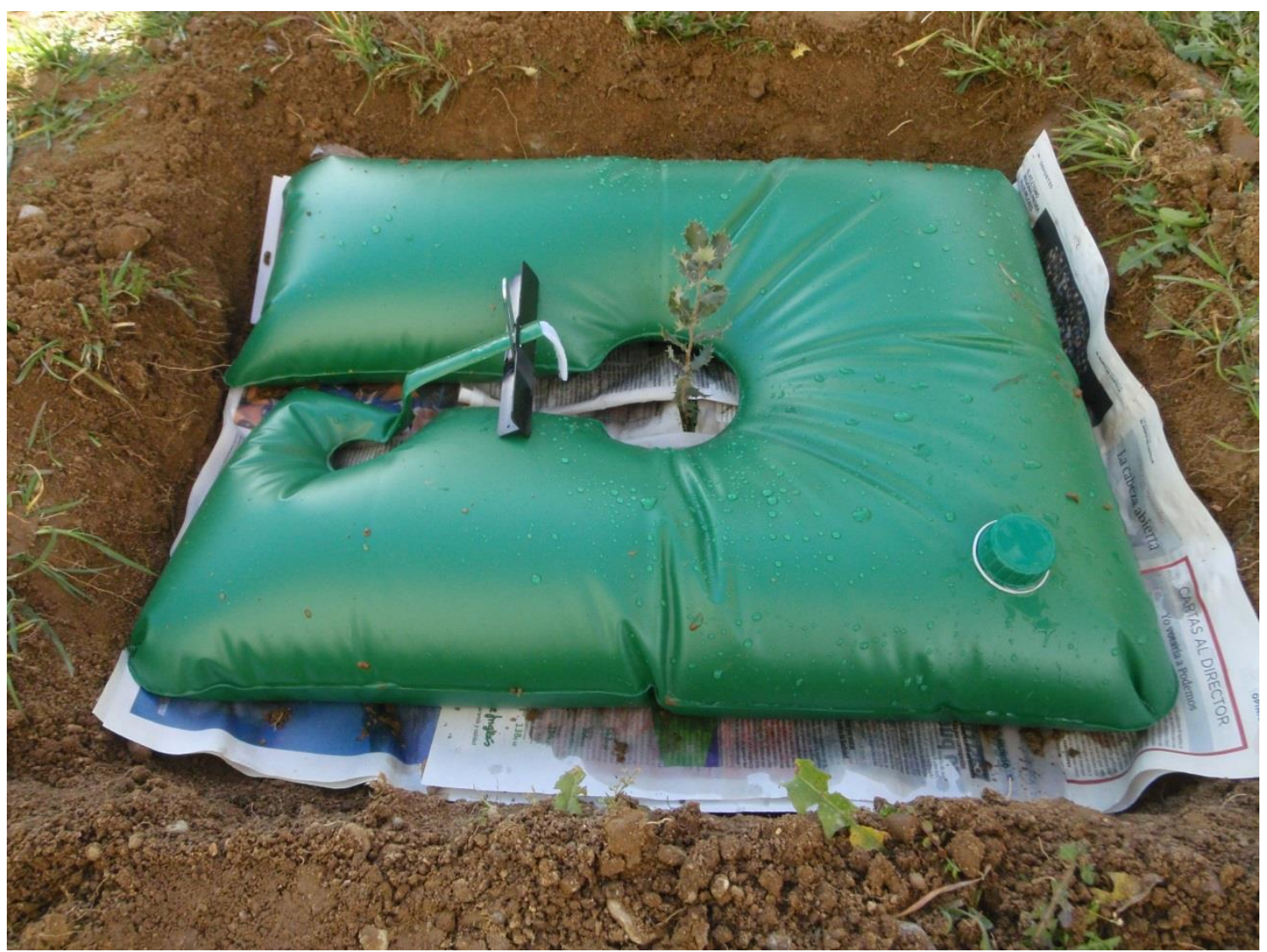

Figura 14. Eco Bag®

Más sofisticado es el Waterboxx ${ }^{\circledR}$, desarrollado en 2008 por una empresa holandesa. Consiste en una caja de polipropileno (PP) con forma cilíndrica (ligeramente troncocónica) que rodea y protege a los brinzales o a las semillas que encierra en su seno. Incluye en su interior un depósito amplio de unos $15 \mathrm{~L}$ de capacidad. El centro de la caja está hueco para permitir el crecimiento de las plantas, que se riegan a través de una mecha instalada en su fondo. El hueco central tiene forma de 8 (Figura 15) para permitir que puedan crecer dos (o más) brinzales en su seno. El depósito tiene dos tapas: un plato o lámina aislante intermedia, y una tapa superior en forma de embudo con costillas y tapón de llenado. El agua de lluvia se recoge a través del embudo y se canaliza al fondo del depósito mediante dos pequeñas bajantes. Bajo ciertas condiciones meteorológicas, el embudo acostillado (que recuerda la forma de un exprimidor) puede actuar como un condensador de rocío, de manera que la autonomía hídrica del sistema puede ser grande, aún en condiciones adversas de sequías prolongadas. En cualquier caso y sin aportación de lluvias ni rocío, el Micro-riego está garantizado durante varios meses, porque la tasa de entrega de agua a través de la mecha es inferior a $0,3 \mathrm{~L}_{\text {día }}{ }^{-1}$. La caja también sirve para eliminar la competencia de especies invasoras, hace de acolchado, reduciendo la evaporación directa de agua desde el suelo humectado y atempera el suelo (Marcos et al., 2012). Debe instalarse en el fondo de un pequeño hoyo de base totalmente horizontal, practicado al realizar la plantación o siembra. Conviene que asome unos pocos centímetros de la superficie del suelo y que quede bien sujeto, haciendo cuerpo con el suelo circundante. La caja hay que llenarla con unos $15 \mathrm{~L}$ de agua al instalarla y efectuar 
la plantación. Se trata de una caja ligera pero de construcción robusta por lo que puede tener varios usos (unos diez años de duración). Además del modelo original en polipropileno, se están ensayando prototipos biodegradables de distintos materiales y con un embudo liso, lo que abarata mucho el producto.

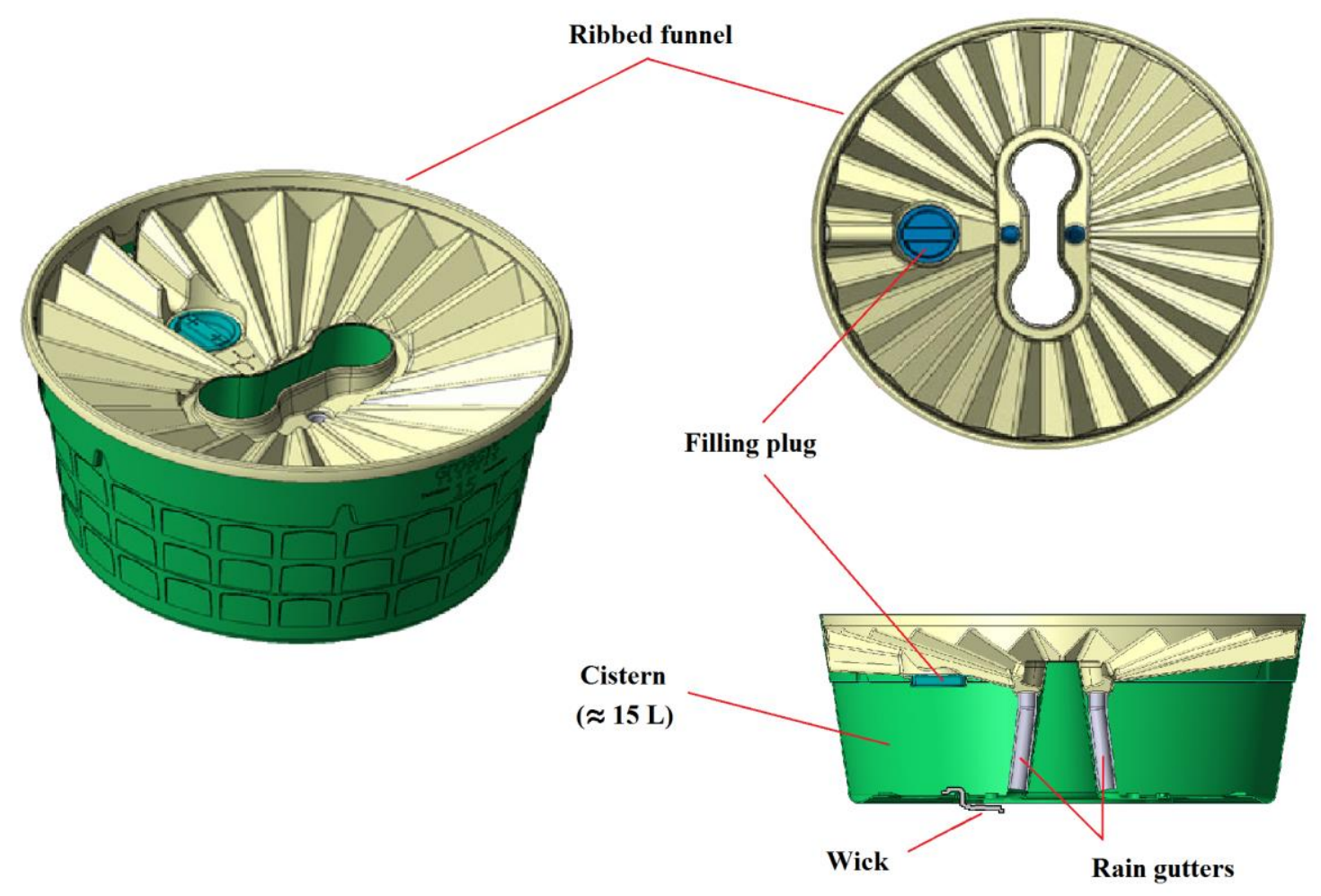

Figura 15. Perspectiva, planta y sección radial de una caja Waterboxx (@ AquaPro)

\subsection{Riego con destiladores solares}

Con la destilación solar se puede obtener agua dulce a partir de materiales vegetales o a partir de aguas contaminadas o saladas. Este agua puede usarse para beber (Jackson y Van Babel, 1965; Baum y Bauramov, 1966; Fath, 1998) o para regar plantas en invernadero (Selçuk y Tran, 1975; Bettaque, 1977; Chaibi, 2000, 2013; El-Awadi et al., 2014) o en campo abierto. Dentro de esta última opción, Howard patenta un sistema de riego por destilación solar en 1972. En 1981 Maldonado establece con éxito duraznos (melocotoneros) en una región desértica de Ramos Arizpe (Coahuila, México). Utiliza nopal picado (Opuntia sp.) para obtener agua por destilación solar. Emplea $75 \mathrm{~kg}$ para cada árbol y trimestre durante los tres primeros años. El nopal picado se pone en un hoyo excavado junto a cada brinzal, quedando cubierto por arriba con una lámina de polietileno. Este material vegetal descansa bien directamente sobre el suelo, bien sobre un recipiente que tiene una manguera para entregar el agua condensada al cepellón del árbol. Constantz $(1989,1991)$ propone y patenta un sistema de riego por destilación solar para cultivos que estén plantados en líneas espaciadas (cultivos de huerta, viñedos, etc.). Entre las líneas instala una lámina plástica negra impermeable que hace de depósito para almacenar el agua a destilar. Sobre esta cubierta pone otra de plástico transparente a modo de tejado por el que resbalan las gotas de agua condensada hasta la línea de 
cultivo. En 1996 Ishimoto patenta un sistema de riego similar, también dirigido a cultivos de huerta (Figuras 16a y 16b).

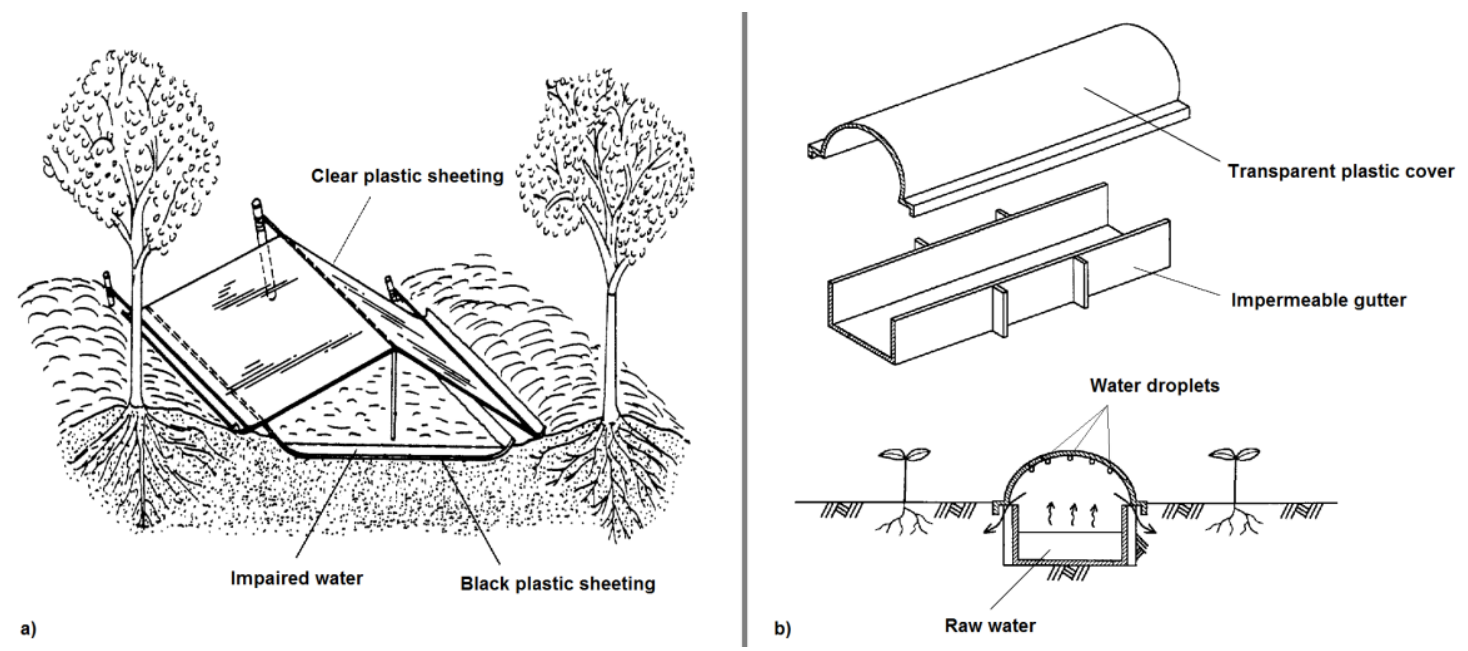

Figura 16. Destiladores solares para regar cultivos agrícolas alineados: a) Sistema patentado por Constantz (1991); b) Sistema de Ishimoto (1996). Reelaborado a partir de las figuras originales de ambas patentes

Más sencillo, práctico y aplicable en repoblación forestal es el sistema ideado por Leimbacher (2008) denominado Kondenskompressor (abreviado: Konkom). Un emisor Konkom está formado por dos botellas reutilizadas de plástico de diferente tamaño (por ejemplo, una de 5 L y la otra de 1,5 L) ensambladas como se muestra en la Figura 17.

La botella grande ha de ser cortada para quitar su base, mientras que la pequeña se corta aproximadamente por su mitad. El recipiente conseguido con la botella pequeña se sitúa lleno de agua junto a la planta que se desee regar. Sobre este recipiente se coloca la botella grande a modo de campana envolvente, centrada e hincada unos centímetros en el suelo. Es importante que la posición relativa entre ambas botellas permita abrir el tapón de la grande para poder rellenar de agua la pequeña.

En el recinto cerrado se reproduce a pequeña escala y de manera simplificada el ciclo del agua. El agua evaporada por el sol se condensa en el techo, las paredes y el suelo del recinto, que en este caso se corresponde con el suelo a regar (Figura 17). Como ecuación característica general se puede escribir:

$$
q=F_{5}\left(L, R_{S}, O p, T, S\right)
$$

en donde: $L$ es una longitud característica que describe el tamaño del destilador $\{\mathrm{m}\}, R_{s}$ es la radiación solar (irradiancia) que recibe el emisor $\left\{\mathrm{W} \cdot \mathrm{m}^{-2}\right\}, T$ es la temperatura ambiental $\{K\}$ y $S$ refleja el tipo de suelo (granulometría y porosidad, fundamentalmente) $\{\mathrm{m}\}$.

El Konkom ha sido ensayado con hortalizas (tomates, judías y calabacines) pero también puede ser útil en reforestación. El aparato proporciona a la planta un riego de coste nulo y sincronizado con sus necesidades, pues se intensifica cuando el sol incide de plano sobre el destilador, es decir: cuando más transpiran las plantas (Martínez de 
Azagra y Del Río, 2012). Aunque se esté regando a pleno día, se pierde muy poca agua por evaporación directa, pues la que no transpira la planta sigue dentro de un circuito semicerrado de evaporación y condensación sin salir del propio destilador solar. Por eso y para aumentar la eficiencia en el aprovechamiento del agua, interesa acolchar (con paja, piedras, etc.) alrededor del Konkom y de la planta, de manera que no asome un frente húmedo a la superficie.

Se consigue reducir la dotación de riego en hasta diez veces con respecto a los sistemas tradicionales de irrigación de huertos, obteniendo rendimientos de cosecha similares (Leimbacher, 2008). Además y como propiedad relevante, este sistema permite emplear aguas salobres o de mar, ya que el sol las transforma en agua dulce. El problema técnico a resolver radica en determinar cuántos emisores son necesarios para regar una planta concreta, con unas necesidades hídricas determinadas. Las primeras experiencias indican que cuatro destiladores formados por una botella PET exterior de $5 \mathrm{~L}$ y una interior de 1,5 L consiguen buenas cosechas de plantas de huerto (Leimbacher, 2008). Se deduce, por tanto, que para dar riegos de apoyo a brinzales xerófitos, un único destilador (5 L/1,5 L) por planta es suficiente.

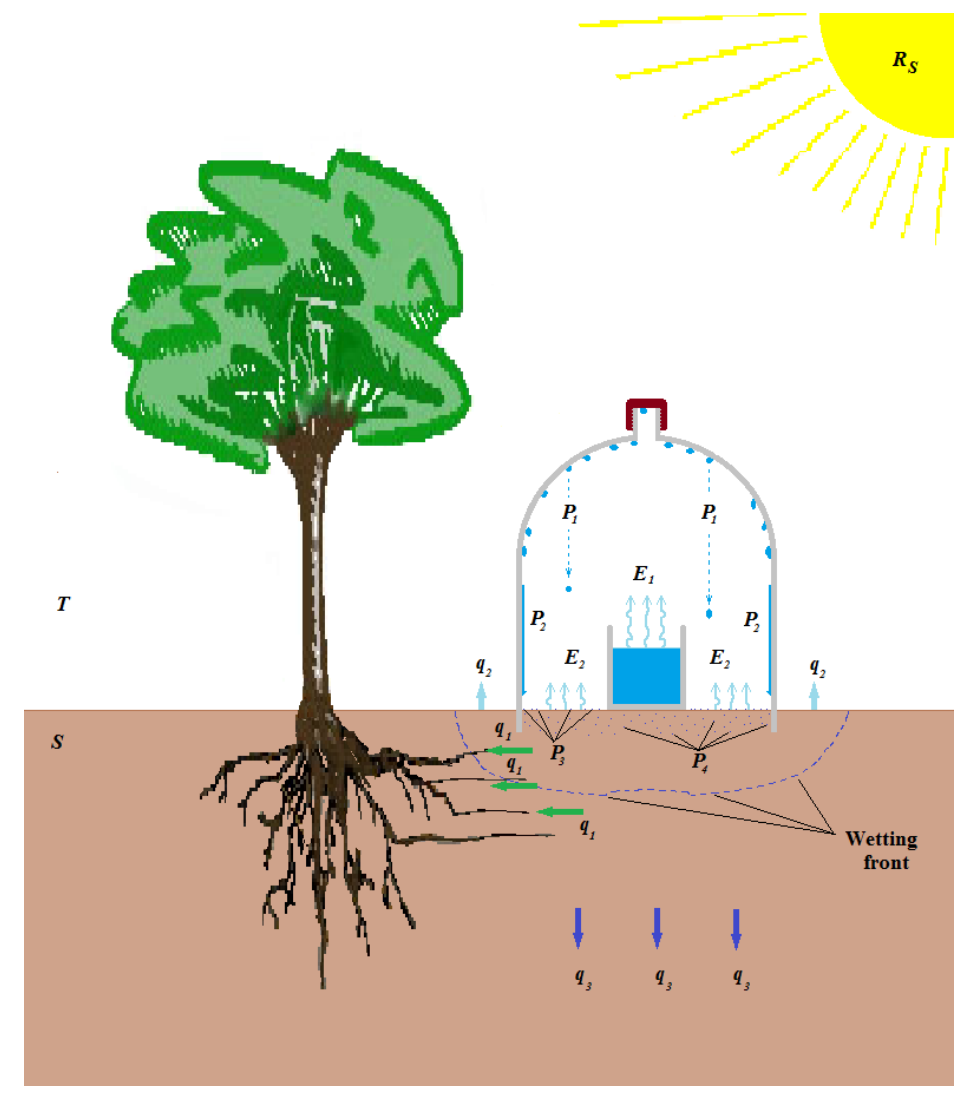

Figura 17. Disposición de las dos botellas del Konkom indicando los parámetros y las variables principales de los que depende su funcionamiento

El Konkom entrega agua al suelo a través de precipitaciones verticales (el goteo desde la cúpula $\left[P_{1}\right]$ y la escorrentía por las paredes de las botellas $\left[P_{2}\right]$ ) y de precipitaciones horizontales (el rocío que se deposita directamente sobre la superficie 
del suelo $\left[\mathrm{P}_{3}\right]$ y las precipitaciones ocultas, es decir: la condensación dentro del suelo $\left.\left[P_{4}\right]\right)$.

En el interior de este emisor de riego se produce un circuito semicerrado de evaporación y condensación desde los distintos elementos del destilador, de ahí el nombre alemán de Kondenskompressor. Únicamente escapa del mencionado ciclo cerrado la humedad que absorben las raíces de las plantas $\left(q_{1}\right)$, y la que sale del perímetro circular de la botella grande hincada en el suelo $\left(q_{2}\right)$ y es evaporada. También puede llegar a percolar parte del agua entregada por el Konkom ( $\left.q_{3}\right)$, escapando de la rizosfera, especialmente en suelos arenosos y durante días muy largos y soleados (Figura 17). Lógicamente, interesa que los dos últimos términos ( $q_{2}$ y $\left.q_{3}\right)$ sean muy pequeños (nulos) para que la eficiencia de aplicación del agua de riego sea próxima a uno.

$$
q=\Delta V=q_{1}+q_{2}+q_{3}=P_{v}+P_{h}-E_{2} \quad[6]
$$

El cuidadoso mantenimiento que requiere este emisor y su fragilidad lo hacen apropiado para la repoblación de pequeños rodales. En el caso de presencia de fauna abundante y si se trabaja con agua salada, la necesidad de vallado resulta evidente, para evitar que el agua pueda derramarse directamente junto a los brinzales.

\section{Comparación entre sistemas de riego}

A partir de la revisión anterior, en la tabla 3 se analizan los distintos sistemas descritos. Las primeras cinco técnicas son las usadas tradicionalmente en regadíos agrícolas, a saber: riego por gravedad, aspersión, microaspersión, y goteo superficial y subterráneo. Las otras catorce técnicas se refieren a sistemas de microrriego no convencionales.

Para establecer la comparativa se han considerado cuatro parámetros clave: el coste de adquisición e instalación del sistema $\left(C_{a}\right)$; la eficiencia en la aplicación del agua $\left(E_{a}\right)$; el mantenimiento del sistema; y la posibilidad de aplicar el riego conjuntamente a varias plantas a la vez.

Respecto del coste $C_{a}$ se ha tomado como valor comparativo de referencia el coste

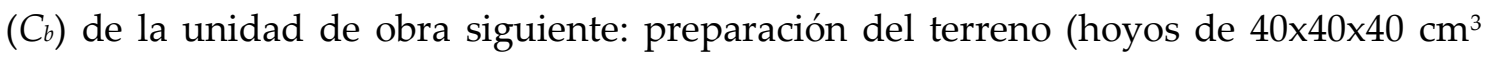
realizados manualmente), distribución de planta, plantación de especies de vivero con una o dos savias en contenedor forestal de $300 \mathrm{~cm}^{3}$ y tapado, que en España está presupuestado en 4,36 €/unidad (TRAGSA, 2015), fijando los siguientes intervalos:

○ Coste muy bajo: $C_{a}<C_{b}$

○ Coste bajo: $C_{b} \leq C_{a}<3,5 \cdot C_{b}$

○ Coste medio: $3,5 \cdot C_{b} \leq C_{a}<7,5 \cdot C_{b}$

○ Coste alto: $7,5 \cdot C_{b} \leq C_{a}<11 \cdot C_{b}$

○ Coste muy alto: $C_{a} \geq 11 \cdot C_{b}$

La eficiencia de aplicación de agua se calcula mediante el cociente del volumen de agua retenido en la rizosfera y transpirado por los brinzales $\left(V_{b}\right)$ entre el volumen de 
agua aplicado por el sistema de riego $\left(V_{a}\right): E_{a}=\frac{V_{b}}{V_{a}}$. Se establecen los siguientes intervalos:

Eficiencia muy baja: $E_{a}<0,6$

○ Eficiencia baja: $0,6 \leq E_{a}<0,7$

○ Eficiencia media: $0,7 \leq E_{a}<0,8$

- Eficiencia alta: $0,8 \leq E_{a}<0,9$

- Eficiencia muy alta: $E_{a} \geq 0,9$

Para evaluar el mantenimiento del sistema de riego es preciso fijarse en su robustez, en su durabilidad y en la necesidad o conveniencia de supervisar los emisores en cada riego. $\mathrm{Al}$ respecto se distingue entre:

- Mantenimiento bajo: Supervisión esporádica; reparaciones muy inusuales

- Mantenimiento medio: Supervisión conveniente en cada riego; reparaciones poco frecuentes

- Mantenimiento alto: Supervisión necesaria en cada riego; ajustes y reparaciones frecuentes

Por último, según que los emisores estén diseñados para su conexión a una red de riego o no, los sistemas se dividen en métodos de aplicación individual o conjunta.

La elección de la mejor alternativa depende de cada situación particular: tipo de microclima, tipo de suelo, relieve, cantidad de agua disponible, calidad y coste de ese agua, especies a regar, número de años en que habrá que aportar agua, superficie (número de plantas) a regar, riesgo de proliferación de malas hierbas, coste de la mano de obra, sencillez en el manejo del sistema, medios mecánicos disponibles para el riego, consideraciones estéticas, paisajismo, riesgo de vandalismo, etc. No existe una solución única mejor para todas las situaciones. El problema hay que plantearlo y resolverlo en cada caso particular concreto, analizando los pros y los contras de cada opción y sin descartar los sistemas de riego convencionales a priori. Así mismo, la alternativa cero (la de no regar aún a riesgo de tener que reponer muchas marras producidas por estrés hídrico) también debe ser considerada (Del Río et al., 2018). 
Tabla 3. Comparación entre los distintos sistemas de riego a brinzales

\begin{tabular}{|c|c|c|c|c|c|c|}
\hline Sistema & Fundamento & Coste & $\begin{array}{l}\text { Eficiencia de } \\
\text { aplicación }\end{array}$ & Mantenimiento & Aplicación & Observaciones \\
\hline $\begin{array}{l}\text { Gravedad } \\
\text { Surface irrigation }\end{array}$ & Infiltración & $\begin{array}{l}\text { Muy } \\
\text { bajo }\end{array}$ & $\begin{array}{l}\text { Muy baja / } \\
\text { Baja }\end{array}$ & Bajo & $\begin{array}{l}\text { Conjunta o } \\
\text { individual }\end{array}$ & $\begin{array}{l}\text { El riego por alcorques } \\
\text { puede plantearse. }\end{array}$ \\
\hline $\begin{array}{l}\text { Aspersión } \\
\text { Sprinkler irrigation }\end{array}$ & $\begin{array}{l}\text { Presión } \\
\text { hidrostática }\end{array}$ & $\begin{array}{l}\text { Muy } \\
\text { alto }\end{array}$ & Baja & Medio & Conjunta & Sistema inadecuado \\
\hline $\begin{array}{l}\text { Microaspersión } \\
\text { Micro-sprinkler } \\
\text { irrigation }\end{array}$ & $\begin{array}{l}\text { Presión } \\
\text { hidrostática }\end{array}$ & $\begin{array}{l}\text { Muy } \\
\text { alto }\end{array}$ & Media & Alto & Conjunta & $\begin{array}{lr}\begin{array}{l}\text { Solución } \\
\text { (preferible }\end{array} & \text { posible } \\
\text { enterrado) } & \end{array}$ \\
\hline $\begin{array}{l}\text { Goteo superficial } \\
\text { Drip irrigation }\end{array}$ & $\begin{array}{l}\text { Presión } \\
\text { hidrostática }\end{array}$ & $\begin{array}{l}\text { Muy } \\
\text { alto }\end{array}$ & Alta & Alto & Conjunta & $\begin{array}{l}\text { Solución posible pero } \\
\text { mejorable enterrando } \\
\text { los emisores }\end{array}$ \\
\hline $\begin{array}{l}\text { Goteo subterráneo } \\
\text { Subsurface drip } \\
\text { irrigation }\end{array}$ & $\begin{array}{l}\text { Presión } \\
\text { hidrostática }\end{array}$ & $\begin{array}{l}\text { Muy } \\
\text { alto }\end{array}$ & Muy alta & Alto & Conjunta & $\begin{array}{l}\begin{array}{l}\text { Solución mejorable } \\
\text { usando } \\
\text { porosas }\end{array} \\
\text { cápsulas }\end{array}$ \\
\hline $\begin{array}{l}\text { Autombomba con } \\
\text { maguera Irrigation of } \\
\text { tree basins with hose }\end{array}$ & $\begin{array}{l}\text { Presión } \\
\text { hidrostática }\end{array}$ & $\begin{array}{l}\text { Muy } \\
\text { baja }\end{array}$ & Alta & $\begin{array}{l}\text { Conjunta } \\
\text { individual }\end{array}$ & Individual & $\begin{array}{l}\text { Sistema muy popular } \\
\text { al no requerir } \\
\text { instalación en campo }\end{array}$ \\
\hline $\begin{array}{l}\text { Tubos verticales } \\
\text { Deep pipes }\end{array}$ & Infiltración & Bajo & $\begin{array}{l}\text { Muy alta } \\
\text { (salvo en } \\
\text { suelos } \\
\text { arenosos) }\end{array}$ & Bajo & Individual & $\begin{array}{l}\text { Sistema muy sencillo } \\
\text { y eficiente }\end{array}$ \\
\hline Irrigasc & Infiltración & Medio & Muy alta & Bajo & Individual & $\begin{array}{l}\text { Sistema adecuado } \\
\text { para arboricultura }\end{array}$ \\
\hline Buried diffuser ${ }^{\circledR}$ & Infiltración & $\begin{array}{l}\text { Muy } \\
\text { alto }\end{array}$ & Muy alta & Alto & Conjunta & $\begin{array}{l}\text { Sistema adecuado } \\
\text { para arboricultura }\end{array}$ \\
\hline $\begin{array}{l}\text { Tubos de drenaje } \\
\text { Horizontal perforated } \\
\text { pipes }\end{array}$ & Infiltración & Bajo & Alta & Bajo & Conjunta & $\begin{array}{l}\text { Buena solución para } \\
\text { barreras cortavientos }\end{array}$ \\
\hline Buried stones pocket & Infiltración & Bajo & Muy alta & Bajo & $\begin{array}{l}\text { Individual o } \\
\text { conjunta }\end{array}$ & $\begin{array}{l}\text { Sistema adecuado en } \\
\text { suelos arcillosos y } \\
\text { profundos para } \\
\text { arboricultura }\end{array}$ \\
\hline $\begin{array}{l}\text { Tarros de barro } \\
\text { Buried pitchers }\end{array}$ & $\begin{array}{l}\text { Potencial } \\
\text { hídrico }\end{array}$ & Bajo & Muy alta & Bajo & $\begin{array}{l}\text { Individual o } \\
\text { conjunta }\end{array}$ & $\begin{array}{l}\text { Las tradicionales } \\
\text { repoblaciones «con } \\
\text { biberón» }\end{array}$ \\
\hline $\begin{array}{l}\text { Cápsulas porosas } \\
\text { Porous capsules }\end{array}$ & $\begin{array}{l}\text { Potencial } \\
\text { hídrico }\end{array}$ & Bajo & Muy alta & Medio / Alto & Conjunta & $\begin{array}{l}\text { Buenos emisores para } \\
\text { riegos por goteo } \\
\text { enterrado }\end{array}$ \\
\hline RIES bottles & $\begin{array}{l}\text { Potencial } \\
\text { hídrico }\end{array}$ & Medio & Muy alta & Bajo & Individual & $\begin{array}{l}\text { Método parecido al } \\
\text { de los tarros de barro }\end{array}$ \\
\hline Microreservoir ${ }^{\circledR}$ & $\begin{array}{l}\text { Presión } \\
\text { potencial } \\
\text { hídrico }\end{array}$ & $\begin{array}{l}\text { Muy } \\
\text { alto }\end{array}$ & Muy alta & Bajo & Conjunta & $\begin{array}{l}\text { Requiere una } \\
\text { pequeña presión de } \\
\text { trabajo }\end{array}$ \\
\hline $\begin{array}{l}\text { Botellas PET con } \\
\text { mechas } \\
\text { PET bottles with wicks }\end{array}$ & $\begin{array}{l}\text { Potencial } \\
\text { hídrico } \\
\text { capilaridad }\end{array}$ & Bajo & Muy alta & Bajo & Individual & $\begin{array}{l}\text { Sistema artesanal } \\
\text { sencillo y eficiente }\end{array}$ \\
\hline $\begin{array}{l}\text { Tarros de barro con } \\
\text { mechas } \\
\text { Pitchers with wicks }\end{array}$ & $\begin{array}{l}\text { Potencial } \\
\text { hídrico } \\
\text { capilaridad }\end{array}$ & Bajo & Muy alta & Bajo & Individual & Sistema combinado \\
\hline Eco Bag ${ }^{\circledR}$ & $\begin{array}{l}\text { Potencial } \\
\text { hídrico } \\
\text { capilaridad }\end{array}$ & Alto & Muy alta & Bajo & Individual & $\begin{array}{l}\text { Puede reutilizarse } \\
\text { varias veces }\end{array}$ \\
\hline Waterboxx ${ }^{\circledR}$ & $\begin{array}{l}\text { Potencial } \\
\text { hídrico } \\
\text { capilaridad }\end{array}$ & $\begin{array}{l}\text { Muy } \\
\text { alto }\end{array}$ & Muy alta & Bajo & Individual & $\begin{array}{l}\text { La caja puede } \\
\text { reutilizarse hasta diez } \\
\text { veces }\end{array}$ \\
\hline Konkom & $\begin{array}{l}\text { Destilación } \\
\text { solar }\end{array}$ & Bajo & Muy alta & Medio & Individual & $\begin{array}{l}\text { Posibilidad de usar } \\
\text { aguas salobres o } \\
\text { salinas }\end{array}$ \\
\hline
\end{tabular}

Tabla basada en datos publicados (Bainbridge, 2007; Martínez de Azagra y Del Río, 2012) y en información facilitada por los fabricantes de cada producto. Se incluyen los métodos clásicos de riego para tener una panorámica conjunta de todas las opciones de riego posibles.

\section{Bibliografía}

Abu-Zreig MM, Atoum MF (2004) Hydraulic characteristics and seepage modelling of clay pitchers produced in Jordan. Canadian Biosystems Engineering 46 (1):15-20 
Abu-Zreig MM, Abe Y, Isoda H (2006) The auto-regulative capability of pitcher irrigation system. Agricultural Water Management 85:272-278

Abu-Zreig MM, Abo-Izreik A, Abd M (2012) Water seepage rate from clay emitters. ASABE Paper Number: 12-13409622012 Annual International Meeting of the American Society of Agricultural and Biological Engineers. St. Joseph. Michigan

Acosta A (2003) Captación de nieblas: fundamentos, experiencias y aplicaciones en el ámbito forestal. Montes 73:59-68

Allué JL, Navarro M (1970) Spain. In: Kaul RN (ed) Afforestation in arid zones. Dr. W. Junk NV Publishers. The Hague. Netherlands

Ashrafi S, Gupta AD, Babel MS, Izumi N, Loof R (2002) Simulation of infiltration from porous clay pipe in subsurface irrigation. Hydrological Sciences - Journal des Sciences Hydrologiques 47 (2):253-268

Bainbridge DA (2001) Buried clay pot irrigation: a little known but very efficient traditional method of irrigation. Agricultural Water Management 48:79-88

Bainbridge DA (2002) Alternative irrigation systems for arid land restoration. Ecological Restoration 20 (1):23-30

Bainbridge DA (2006) a) Deep pipe irrigation. Available on http://www.agroforestry.net/pubs/Deep\%20pipe\%20irrigation.pdf

Bainbridge DA (2006) b) Beyond Drip Irrigation - Hyper-efficient Irrigation. Presentation at the 2006 ASABE Annual International Meeting. Portland. Oregon. Proceedings of the American Society of Agricultural and Biological Engineers. Paper \# 062073. St. Joseph (Michigan)

Bainbridge DA (2007) A guide for desert and dryland restoration. New hope for arid lands. Island Press. Washington

Bainbridge DA (2012) Wick irrigation for tree establishment. Available at: http://agroforestry.net/overstory/overstory249.html

Bainbridge DA, Fidelibus M, MacAller R (1995) Techniques for plant establishment in arid ecosystems. Restoration and Management Notes 13:190-197

Baker FS (1955) California's forest regeneration problems. Department of Natural Resources. Division of Forestry. State Board of Forestry, Regeneration Committee. Sacramento. California

Baum VA, Bairamov R (1966) Prospects of solar mills in Turkmenia. Solar Energy 10 (1):38-40

Bean TM, Smith SE, Karpiscak MM (2004) Intensive revegetation in Arizona's Hot Desert: The Advantages of Container Stock. Native Plants Journal 5 (2):173-180. doi:10.2979/NPJ.2004.5.2.173

Bettaque R (1977) Verfahren zum Betreiben von Gewächshäusern mit Salzwasser. Der Tropenlandwirt, Beiheft 10. Witzenhäuser Hochschulwoche

Chahbani B (1992) The "buried stones pocket": A new irrigation technique for tree plantations in arid zones. In: Water Saving Techniques for Plant Growth (Editors: Verplancke HJW, De Strooper EBA, De Boodt MFL). Kluwer Academic Publishers, pp 213-222

Chahbani B (2004) Innovations techniques pour l'optimisation de la collecte, de laconservation et de l'utilisation de l'eau pour un développement durable de l'agriculture pluviale dans les régions arides. In: Cantero C, Gabiña D (eds). Mediterranean rainfed agriculture: Strategies for sustainability. CIHEAM. Zaragoza. Spain

Chahbani B (2012) The buried diffuser. Available on http://www.chahtech.com/

Chaibi MT (2000) An overview of solar desalination for domestic and agriculture water needs in remote arid areas. Desalination 127:119-133

Chaibi MT (2013) Thermal solar desalination technologies for small-scale irrigation. American Journal of Energy Research 1 (2):25-32 
Constantz J (1989) Distillation irrigation: a low-energy process for coupling water purification and drip irrigation. Agricultural Water Management 15 (3):253-264

Constantz J (1991) Apparatus for water desalination and drip irrigation of row crops. United States Patent 5067272

Cooper PI (1969) The absorption of radiation in solar stills. Solar Energy 12 (3):333-346

Del Río J, Gómez E, Reque JA, Martínez de Azagra A (2013) Reponer marras o regar brinzales: una disyuntiva a analizar en zona árida. In: Martínez C, Lario FJ, Fernández B (eds): Avances en la restauración de sistemas forestales. Técnicas de implantación, Madrid, España. Sociedad Española de las Ciencias Forestales - Asociación Española de Ecología Terrestre 13-18

Del Río J, Reque JA, Martínez de Azagra A (2018) To replant or to irrigate: A silvicultural decision model for afforestation projects. Forest Policy and Economics 93:18-29. doi:10.1016/j.forpol.2018.05.007

El-Awadi MH, El-Ghetany HH, Latif MA (2014) Experimental investigation of an integrated solar green house for water desalination, plantation and wastewater treatment in remote arid egyptian communities. Energy Procedia 50:520-527

Estrela MJ, Valiente JA, Corell D, Fuentes D, Valdecantos A (2009) Prospective use of collected fog water in the restoration of degraded burned areas under dry Mediterranean conditions. Agricultural and Forest Meteorology 149:1896-1906

Fath HES (1998) Solar distillation: a promising alternative for water provision with free energy, simple technology and a clean environment. Desalination 116:45-56

Gasc J (2002) La lutte contre la désertification. Mondes et cultures 62:313-320. Académie des Sciences d'Outre-mer. Paris

Ghaibeh AR (2001) Case Study 10: Water Conservation Technology (Ceramics). In: Sourcebook of Alternative Technologies for Freshwater Augmentation in West Asia. International Environmental Technology Centre. United Nations Environment Programme, pp 333-335

Gopinath K, Veeravalli SV (2011) Auto-regulative capability of pot/pitcher irrigation. Journal of Scientific and Industrial Research 70:656-663

Grantz DA, Vaughn DL, Farber RJ, Kim B, Ashbaugh L, Vancuren T, Campbell R, Bainbridge D, Zink T (1998) Transplanting native plants to revegetate abandoned farmland in the western Mojave Desert. Journal of Environmental Quality 27, pp 960-967

Howard LV (1972) Solar distillation irrigation apparatus. United States Patent 3653150

Hirschmann JR (1975) Solar distillation in Chile. Desalination 17 (1):31-67

Igbadun HE, Barnabas J (2013) Hydraulic characteristics of porous clay pipes for subsurface irrigation. The Pacific Journal of Science and Technology 14 (1):40-47

Ishimoto J (1996) Distillation irrigation apparatus. European Patent 0745321 A1

Jackson RD, Van Bavel CHM (1965) Solar distillation of water from soil and plant materials: A simple desert survival technique. Science 149:1377-1379

James EJ (2006) Traditional practices in Kerala. Protecting nature's gift. Kerala Calling (May 2006):12-19

Jethwa AP (1993) Notes on afforestation of arid lands of Kachchh district in Gujarat state. In: Dwivepi AP, Gupta GN (eds) Afforestation of arid lands. Scientific Publishers. Jodhpur. India

Karmeli D, Keller J (1975) Trickle irrigation design. Rain Bird Sprinkler Manufacturing Corporation. Glendora. California

Leimbacher A (2008) Kodenskompressor. Solar drip irrigation. Goteo solar. Available on http://flutgut.com/blog/

Madhlopa A, Clarke JA (2013) Computation of irradiance in a solar still by using a refined algorithm. Renewable Energy 51:13-21 
Maldonado L (1981) Métodos de riego por destilación solar. In: IICA Biblioteca Venezuela (eds) Memorias del IV Seminario Latinoamericano de Riego por Goteo. Barquisimeto, Venezuela, pp 145-151

Marcos JL, Ortiz L, Garrido F, Clérigo Z, Hernández S, Gil ML, Ortiz J (2013) Efecto termoaislante del Waterboxx en las repoblaciones forestales. $6^{\circ}$ Congreso Forestal Español. Vitoria. Spain. Available on http://secforestales.org/publicaciones/index.php/congresos/article/view/10654

Marigowda MH (1974) Dry orcharding. The Lal Baugh 19 (1/2):1-85

Martín L, Garro MC, De la Fuente J, Sardinero S, Fernández F, Gegúndez P, Guzmán T, Púa F (2014) Técnicas de restauración en ecosistemas áridos y semiáridos. Congreso Nacional de Medio Ambiente 2014. Madrid

Martínez J, Reca J (2014) Water use efficiency of surface drip irrigation versus an alternative subsurface drip irrigation method. Journal of Irrigation and Drainage Engineering, 140 (10): doi:10.1061/(ASCE)IR.1943-4774.0000745

Martínez de Azagra A (1996) Diseño de sistemas de recolección de agua para la repoblación forestal. MundiPrensa. Madrid

Martínez de Azagra A, Del Río J (2012) Los riegos de apoyo y de socorro en repoblaciones forestales. Foresta 53:32-44

Martínez de Azagra A, Del Río J (2015) Microrriego de brinzales a través de recipientes porosos enterrados: Fundamentos teóricos y prácticos. Comunicación a la III Reunión del Grupo de Trabajo de Hidrología Forestal. Valencia

Mathieu C (2006) Une méthode d'irrigation par semi-conduites verticales adaptée aux zones sahéliennes. Résultats techniques et prospective de l'organisation des filières. Tropicultura 24 (2):120-123

Matorel M (1996) Programa piloto de reforestación extensiva. Bosques para el futuro. Documento inédito. Universidad de Piura (Perú)

Matorel M (1998) Riego en el desierto. Reservorios de exudación subterránea. Revista Agronoticias, 223: 34 (Lima, Perú)

Matorel M (2006) Método para reforestar en ausencia de lluvias. Microrreservorios de exudación subterránea. Boletín № 23 de DarwinNotas. Available on http://www.darwinnet.org/docs/microreservorios.pdf

Mehta AV, Vyas A, Bodar N, Lathiya D (2011) Design of solar distillation system. International Journal of Advanced Science and Technology 29:67-74

Memon AH, Soomro AG, Gadehi MA (2010) Water use efficiency and saving through pitcher and polyethylene bag over furrow irrigation. Pakistan Journal of Agriculture, Agricultural Engineering and Veterinary Sciences 26 (1):16-29

Mondal RC (1974a) Farming with pitcher: a technique of water conservation. World Crops 26 (2):91-97

Mondal RC (1974b) Pitcher farming: a simple low-cost method of irrigation. Appropriate Technologies 13:78

Murphy T (1989) Planting in extreme climates. Journal of Arid Lands Permaculture 8 (1):6-7

Navarro RM, Martínez A (1997) Las marras producidas por ausencia de cuidados culturales. Cuadernos de la Sociedad Española de Ciencias Forestales 4:43-57

Navarro J, Martínez de Azagra A, Mongil J (2009) Recolección de agua en ambientes áridos para el desarrollo agrícola y forestal. In: Navarro J, Martínez de Azagra A, Mongil J (eds) Hidrología de Conservación de Aguas. Captación de precipitaciones horizontales y escorrentías en zonas secas. Universidad de Valladolid. Valladolid. España

Olguín C (1975) Riego por succión. Descripción del método y avances en la investigación. En: Memorias del 1er Seminario Nacional de Riego por Goteo (tomo II:165- 181. Hermosillo. Sonora. México 
Olguín C (1977) Observaciones sobre el efecto de riego por succión en el rendimiento y desarrollo de maíz (variedad H-507) en el distrito de riego №. 41, Río Yaqui. Sonora. Memorándum Técnico, 364. SARH, México

Ortega F, Forbes T, De la Rosa S (1986) Uso de potes porosos en la repoblación forestal, en suelos de zonas secas. Ciencias de la Agricultura 27:159-160

Ortmann G (1991) Urlaubssichere Bewässerung für Pflanzen. Paul Parey. Hamburg

Prabu MJ (2008) An ingenious irrigation technique for small holdings. The Hindu, April 10, 2008

Prinz D (2001) Water Harvesting for Afforestation in Dry Areas. Proceedings of the 10th International Conference on Rainwater Catchment Systems, Mannheim, Germany, 10-14 Sept. 2001, pp 195-198

Qiaosheng S, Zuoxin L, Zhenying W, Haijun L (2007) Simulation of the soil wetting shape under porous pipe sub-irrigation using dimensional analysis. Irrigation and Drainage 56:389-398

Rendón L (1981) Desarrollo y calibración de un modelo matemático para riego por succión. Agrociencia 45:119-135

Ruiz De la Torre J, Carreras C, García JI, Orti M (1996) Manual de la flora para la restauración de áreas críticas y diversificación en masas forestales. Consejería de Medio Ambiente de la Junta de Andalucía. Sevilla. Spain

Sánchez J Ortega R Hervás M Padilla FM, Pugnaire, FI (2004) El microrriego, una técnica de restauración de la cubierta vegetal para ambientes semiáridos. Cuadernos de la Sociedad Española de Ciencias Forestales 17:109-112

Santamarta JC, Seijas J (2010) Fundamentos y tecnologías para la captación y uso del agua procedente de la lluvia horizontal en los montes canarios. Revista Montes 100:15-21

Serrada R, Navarro RM, Pemán J (2005) La calidad de las repoblaciones forestales: una aproximación desde la selvicultura y la ecofisiología. Investigación Agraria: Sistemas y Recursos Forestales 14 (3):462-481

Selçuk MK, Tran VV (1975) Solar stills for agricultural purposes. Solar Energy 17:103-109

Setiawan BI, Hermanto MB, Pakpahan A (2009) Utilization of sidoarjo mud to develop pitcher for irrigation. International Symposium on Agricultural Engineering: Toward Sustainable Agriculture in Asia. Indonesian Society of Agricultural Engineers. Bogor (Indonesia)

Sheng-Han S (1974) On "Fan Shêng-chih Shu": An Agriculturist Book of China written by Fan Shêng-chih Shu in the First Century BC. Science Book. Peking, pp 36-37

Shiekh MT, Shah BH (1983) Establishment of vegetation with pitcher irrigation. Pakistan Journal of Forestry 33 (2):75-81

Silva AD, Magalhães AD, Santos ED, Morgado LB (1982) Irrigação por potes de barro: I. Descrição do método e testes preliminares. Boletim de Pesquisa, 10. Empresa Brasileira de Pesquisa Agropecuaria (EMBRAPA) y Centro de Pesquisa Agropecuaria do Trópico Semi-Arido (CPATSA). Petronila. Brasil

Siyal AA, Skaggs TH (2009) Measured and simulated soil wetting patterns under porous clay pipe subsurface irrigation. Agricultural Water Management 96:893-904

Siyal AA, Van Genuchten MT, Skaggs TH (2009) Performance of pitcher irrigation system. Soil Science 174 (6):312-320

Squeo FA, Jiménez M, Albán L, Reyes J, Gutiérrez J, Holmgren M (2007) Tree establishment along an ENSO experimental gradient in the Atacama Desert. Journal of Vegetation Sciences 18:195-202

Stein TM (1994) Grundlagen und Technik der Gefäßbewässerung. Zeitschrift für Bewässerungswirtschaft. Journal of Applied Irrigation Science 29 (1):62-94

Stein TM (1995) Hydraulische Leitfähigkeit von Gefäßmaterialien zur Gefäßbe-wässerung - Erste Versuchsergebnisse. Zeitschrift für Bewässerungswirt-schaft. Journal of Applied Irrigation Science 30 (1):72-93 
Stein TM (1996) Möglichkeiten der Veränderung der hydraulischen Leitfähigkeiten von Gefäßbewässerungsmaterialien. Zeitschrift für Bewässerungswirtschaft. Journal of Applied Irrigation Science 31 (2):165-181

Stein TM (1997a) Der Einfluß der Verdunstung, der hydraulischen Leitfähigkeit, der Wanddicke und der Oberfläche auf die Perkolationsrate von Gefäßen zur Gefäßbewässerung. Zeitschrift für Bewässerungswirtschaft. Journal of Applied Irrigation Science 32 (1):65-84

Stein TM (1997b) Der Einfluß der Kultur und anderer Faktoren auf die Perkolationsrate von Gefäßen zur Gefäßbewässerung. - Zeitschrift für Bewässe-rungswirtschaft. Journal of Applied Irrigation Science 32 (2):207-234

Stein TM (1998) Erarbeitung und Überprüfung von Entwurfskriterien für Gefäßbewässerungsanlagen. Der Tropenlandwirt. Journal of Agriculture in the Tropics and Subtropics 66:1-175

Tilló J (2006) Riego por exudación. Congreso Internacional ApliMatec 06, Aplicaciones Técnicas de los Materiales Textiles. Valencia. Spain

Tiwari GN, Singh HN, Tripathi R (2003) Present status of solar distillation. Solar Energy 75 (5):367-373

TRAGSA (2014) Price lists of forest works and labours in Spain. Available on http://www.tragsa.es/es/acerca-del-grupo/Paginas/tarifas-tragsa.aspx

UNEP (1997) Sourcebook of alternative technologies for freshwater augmentation in Latin America and the Caribbean. Chapters 4.2 y 5.7 (about porous capsules). UNEP / OAS. Washington. Available on http://www.greenstone.org

Valiente JA, Estrela MJ, Corel D, Fuentes D, Valdecantos A, Baeza MJ (2011) Fog water collection and reforestation at mountain location in a western mediterranean basin region: air-mass origins and synoptic analysis. Erdkunde 65 (3):277-290. doi:10.3112/erdkunde.2011.03.05

Vargas P (2012) Tecnología de riego por succión. Primeras experiencias en Cuba. Editorial Académica Española. Saarbrücken. Germany

Vasudevan P, Thapliyal A, Tandon M, Dastidar MG, Sen PK (2014) Factors controlling water delivery by pitcher irrigation. Irrigation and Drainage 63:71-79

Wesonga JM, Wainaina C, Ombwara FK, Masinde PW, Home PK (2014) Wick material media for capillary wick based irrigation system in Kenya. International Journal of Science and Research 3 (4):613- 617 


\section{Capítulo 3. Ámbitos de estudio científico sobre la tecnología del riego para el establecimiento de brinzales}

Con el fin de conocer cuáles son los ámbitos de estudio de la ciencia en materia de riego de brinzales, se plantea una revisión sistemática de la bibliografía científica. Los resultados señalan tres grandes áreas de interés: la relativa a la planificación, la descripción de experiencias sobre el uso del riego en la producción de cultivos en geografías sensibles a los efectos de la desertificación y del cambio climático, y la caracterización del funcionamiento hidráulico de los sistemas. 


\section{Temas centrales en el estudio científico del riego de brinzales}

Con el fin de determinar los temas centrales de estudio en el campo del riego de brinzales que se han realizado hasta la fecha, se efectúa una revisión sistemática (Lee et al., 2014) de los artículos indexados en las bases bibliográficas científicas en el periodo 1970-2017.

\section{Material y métodos}

Las fuentes de datos seleccionadas son las bases de datos de Scopus y Google Scholar: la base de Scopus se utiliza para detectar los temas científicos y la base Google Scholar para obtener una perspectiva más amplia, e incluir los contenidos de libros, manuales, informes, patentes $\mathrm{u}$ otro tipo de publicaciones en canales no indexados en SJR (SCImago Journal Rank). Mientras que el criterio de búsqueda seleccionado para Scopus describe el campo analizado, en Google Scholar se han elegido palabras clave más detalladas que eviten la inclusión de otros ámbitos, relacionados con el riego, alejados del forestal (Tabla 1).

Tabla 1. Características de las bases de datos empleadas en la revisión sistemática de las publicaciones sobre micro-riego de brinzales y parámetros del algoritmo de clasificación de términos en los títulos

\begin{tabular}{lcccc}
\hline Criterio de búsqueda & $\begin{array}{c}\text { Base de } \\
\text { datos }\end{array}$ & Artículos & $\boldsymbol{H}$ & $\begin{array}{c}\text { Términos en títulos } \\
\text { por número de } \\
\text { ocurrencias }\end{array}$ \\
\hline $\begin{array}{l}\text { microirrigation AND tree seedlings AND survival } \\
\text { - nursery (1970-2017) }\end{array}$ & $\begin{array}{l}\text { Google } \\
\text { Scholar }\end{array}$ & 1286 & 64 & $120 / 5$ \\
$\begin{array}{l}\text { microirrigation OR micro-irrigation AND } \\
\text { seedling(1970-2017) }\end{array}$ & Scopus & 1594 & 59 & $79 / 10$ \\
\hline
\end{tabular}

La búsqueda se ha realizado el 06/05/2017 mediante el programa Publish or Perish (Harzing, A.W., 2007. Publish or Perish. Actualización 2018. Versión 6.3.1. Disponible en http://www.harzing.com/pop.htm). Se obtiene indicadores relativos a la producción del periodo, en número de artículos publicados, y al impacto de las publicaciones, mediante el índice $H$ (Hirsch, 2005)

Los términos presentes en los títulos de las publicaciones de cada una de las bases, fueron sometidos a un proceso de agrupamiento mediante el algoritmo de dos dimensiones de modularidad, variante ponderada y parametrizada (Van Eck y Waltman, 2007, 2009; Waltman et al., 2010). Este algoritmo forma los grupos por la relación de cercanía en la ocurrencia entre los términos.

El proceso se ha realizado mediante el software Vosviewer (Center for Science and Technology Studies- Leiden University. 2013. Vosviewer. Actulización 2018. Versión 1.54., disponible en: http://www.vosviewer.com).

El algoritmo obtiene un corpus inicial de los términos de los títulos que se repiten, al menos, 10 veces en Scopus y 5 en Google Scholar. La diferencia de valores del umbral se debe al criterio de obtener una densidad de palabras del mismo orden de magnitud 
en ambas bases que permitan identificar los temas de interés con igual grado de detalle. Los parámetros del algoritmo de clasificación de los términos en los títulos de las publicaciones son: Método de normalización de modularidad, con atracción $=1$, repulsión $=0$ y resolución $=1$. Mínimo tamaño del grupo $=1$, y agrupación de pequeños clúster con tamaño mínimo $=10$.

\section{Resultados}

Las características de la selección obtenida como resultado de la consulta a ambas bases son muy similares en número de artículos e índice $H$ (Tabla 1).

\subsection{La evolución temporal del número de publicaciones}

Aunque las publicaciones sobre micro-riego comenzaron en la década de 1970, es a partir del comienzo del siglo XXI cuando se produce un aumento en la producción de publicaciones. Esa tendencia continuó durante 15 años, hasta que a partir del 2010 se estabilizó en el rango de las 90 a 110 publicaciones anuales (Figura 1). Ambas bases presentan un comportamiento sincrónico, observándose sólo en algunos años algún desfase temporal entre ambas.

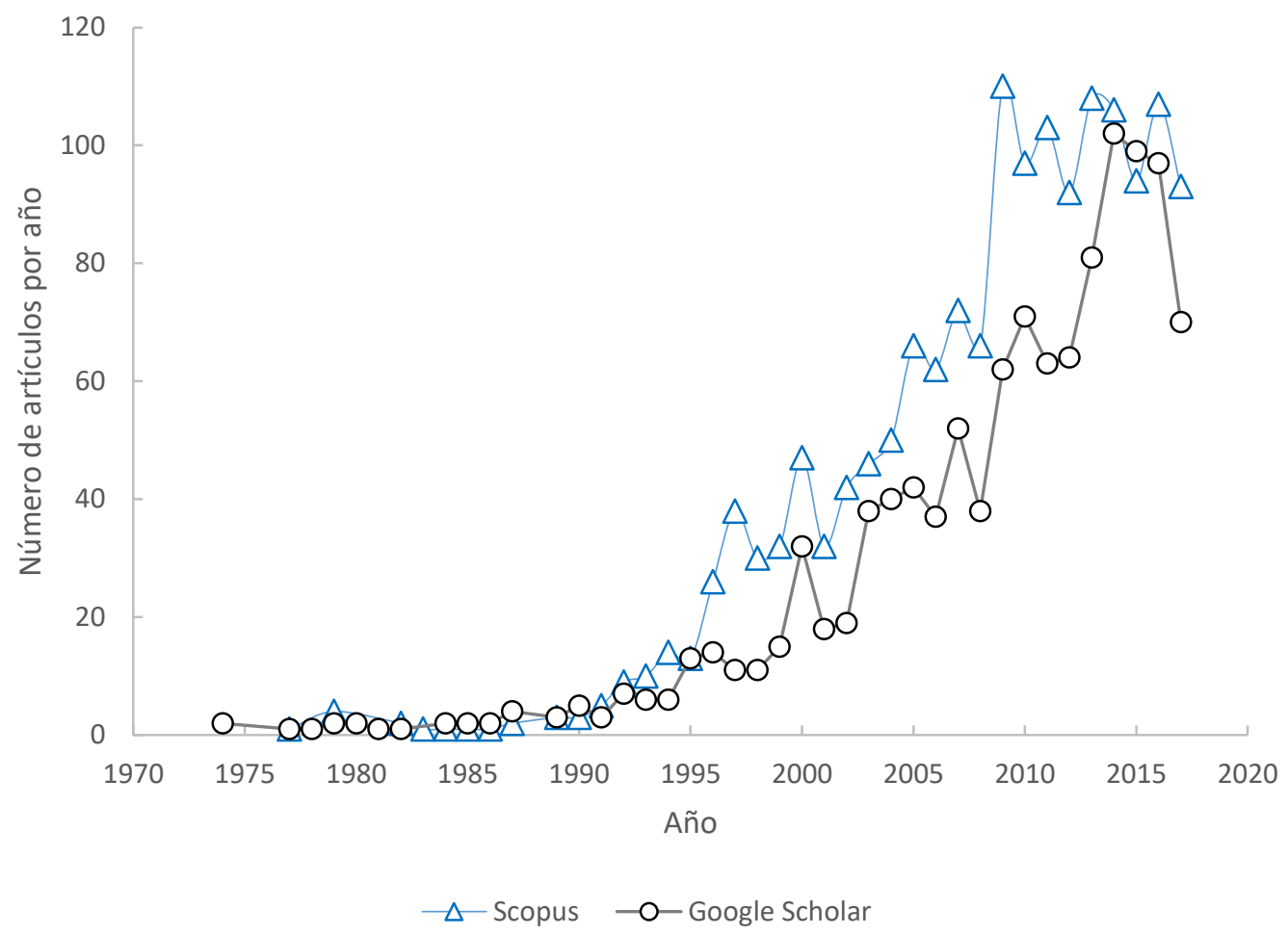

Figura 1. Evolución anual (1970-2017) de las publicaciones de micro-riego y brinzales

\subsection{Los temas de investigación}

El mapa resultante del análisis de las palabras de los títulos identificó cuatro grupos en la base de Scopus (Figura 2) y seis grupos en la base de Google Scholar (Figura $3)$. 


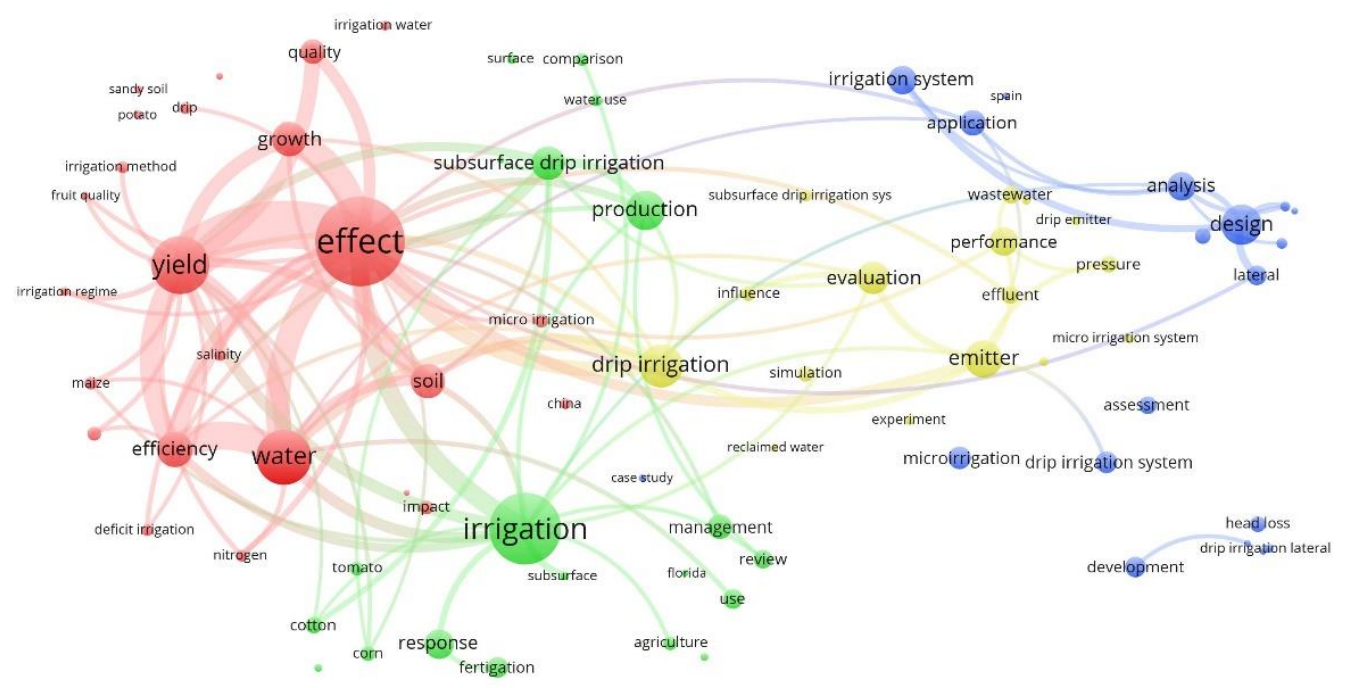

Figura 2. Mapa de términos en la base bibliográfica de Scopus

Nota: Salida gráfica de VOSviewer v.1.5.4. El tamaño de las etiquetas es una indicación de la frecuencia de ocurrencia de cada palabra clave y los diferentes colores representan grupos de palabras. En general, cuanto más corta sea la distancia entre dos términos, más cercana será su relación (mayor número de co-ocurrencias en grupos de palabras clave).

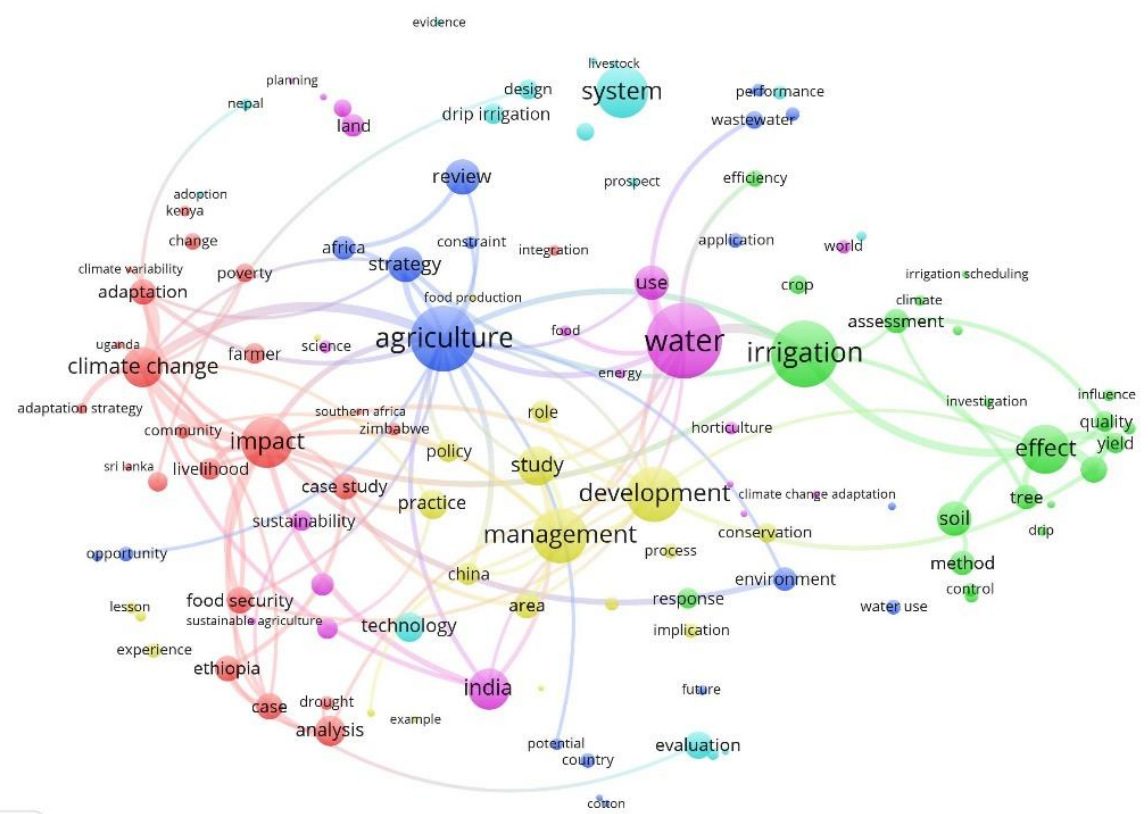

Figura 3. Mapa de términos en la base bibliográfica de Google Scholar

Nota: Salida gráfica de VOSviewer v.1.5.4. El tamaño de las etiquetas es una indicación de la frecuencia de ocurrencia de cada palabra clave y los diferentes colores representan grupos de palabras. En general, cuanto más corta sea la distancia entre dos términos, más cercana será su relación (mayor número de co-ocurrencias en grupos de palabras clave).

A través del examen de las palabras clave empleadas con mayor frecuencia en cada grupo de términos y de la revisión compresiva de los artículos, se han nombrado los temas para describir cada grupo. En la tabla 2 se presentan los temas detectados, ordenados de mayor a menor ocurrencia. 
Tabla 2. Temas de investigación en micro-riego y brinzales según revisión sistemática (1970-2017)

\begin{tabular}{|c|c|c|c|}
\hline Nivel jerárquico & Tipo de publicación & Tema & Fuente de datos \\
\hline Estrategias & Casos de estudio & $\begin{array}{l}\text { Adaptación al impacto del cambio } \\
\text { climático y a las sequías. Seguridad } \\
\text { alimentaria }\end{array}$ & Google Scholar \\
\hline Operacionales & $\begin{array}{l}\text { Artículos-Libros- } \\
\text { Conferencias }\end{array}$ & $\begin{array}{l}\text { Manejo del riego. Efectos en el } \\
\text { crecimiento y rendimiento y calidad de } \\
\text { árboles y cultivos }\end{array}$ & Google Scholar \\
\hline Operacionales & Artículos & Eficiencia en el uso del agua & Scopus \\
\hline Operacionales & Artículos & Producción y crecimiento de cultivos & Scopus \\
\hline Evaluación & Artículos-Libros & Aplicación en la agricultura de regadío & Google Scholar \\
\hline Políticas & $\begin{array}{l}\text { Lecciones } \\
\text { aprendidas }\end{array}$ & $\begin{array}{l}\text { Desarrollo rural. Producción de } \\
\text { alimento y reducción de la pobreza }\end{array}$ & Google Scholar \\
\hline Gestión sostenible & $\begin{array}{l}\text { Artículos-Libros- } \\
\text { Conferencias }\end{array}$ & Recursos hídricos para el sector agrícola & Google Scholar \\
\hline Técnicas & $\begin{array}{l}\text { Artículos-Libros- } \\
\text { Conferencias }\end{array}$ & Diseño. Adopción tecnológica & Google Scholar \\
\hline Técnicas & Artículos & Evaluación y rendimiento de emisores & Scopus \\
\hline Técnicas & Artículos & Diseño hidráulico & Scopus \\
\hline
\end{tabular}

Google Scholar une la literatura gris y los artículos de investigación publicados sobre micro-riego y brinzales en el periodo 1970-2017. En esta fuente de datos, las publicaciones del periodo 1970-2017 dibujan una visión amplia sobre el micro-riego y los brinzales. La discusión incluye a todos los niveles jerárquicos implicados en el proceso de planificación. Estos niveles abarcan cuestiones políticas, estratégicas, de gestión y evaluación para finalizar con temas operacionales y técnicos.

El tema tratado con mayor frecuencia es la descripción de los casos de uso y lecciones aprendidas obtenidas de los niveles de jerarquía más amplios, relacionados con las políticas y estrategias, y muy ligados a la reducción de la pobreza y la seguridad alimentaria. El siguiente tema que sobresale está relacionado con las operaciones de manejo del riego y su efecto en la producción, crecimiento y calidad de cultivos y árboles. A continuación, destaca el tema de la evaluación de la tecnología del micro-riego en la agricultura de regadío, especialmente aplicada a la fruticultura, para posteriormente dar paso a la gestión sostenible de los recursos hídricos. Los temas técnicos de diseño del micro-riego junto con las cuestiones relativas a la adopción tecnológica son los que han recibido menos atención en las publicaciones.

Los temas identificados a través de Scopus profundizan en los ámbitos operacionales y técnicos, en dos líneas de trabajo distintas. El primer tema está centrado en el efecto de la tecnología sobre los cultivos y la eficiencia en el uso del agua. En el segundo tema, Scopus detecta un doble interés, tanto en el dimensionamiento hidráulico como en la evaluación y rendimiento de los emisores. 
A partir de las localizaciones incluidas en los títulos de las publicaciones se dibuja la distribución geográfica de los temas de interés (Figura 4). Se distinguen tres grandes áreas donde se concentran las publicaciones sobre micro-riego que no están conectadas geográficamente.

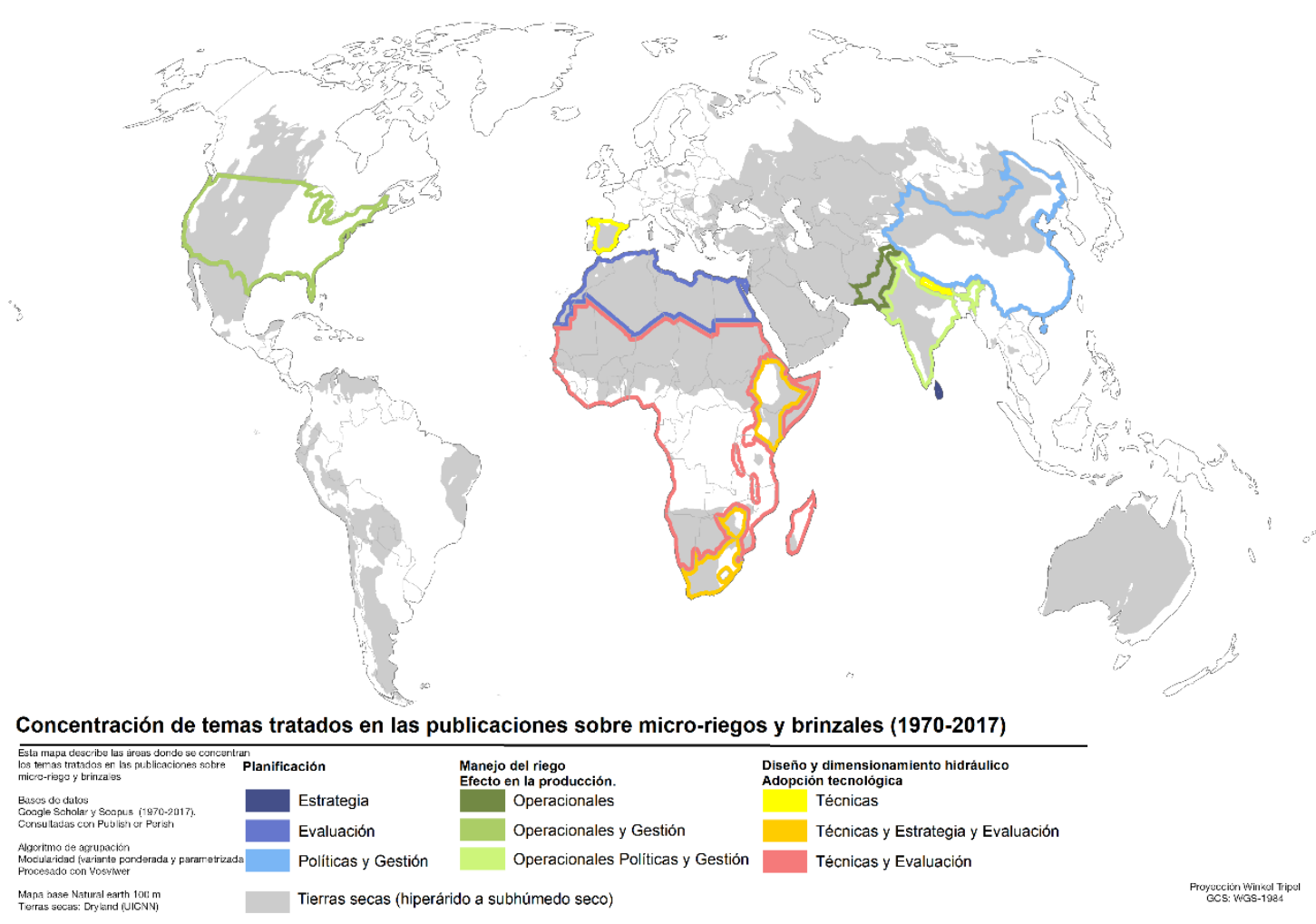

Figura 4. Mapa de la distribución geográfica de temas tratados en las publicaciones sobre riegos de brinzales

Una vez identificados los temas y su distribución geográfica, se han evaluado en ellos, la producción de publicaciones mediante el índice normalizado medio de ocurrencias y su impacto, a través del índice normalizado medio de citaciones (Van Eck y Waltman, 2009). También se ha estimado el año medio de publicación de los artículos clasificados en cada grupo para conocer la evolución temporal de los temas de interés (Figura 5).

En todos los temas, la producción de publicaciones es superior al impacto que han obtenido. Los temas relacionados con el diseño hidráulico y los efectos del microriego y su programación en la producción de los cultivos, divergen de esta tendencia y su impacto en citas, supera a la producción.

En el tiempo, los primeros temas que se abordaron fueron los de evaluación de la potencialidad y limitaciones de la tecnológica junto con su papel como herramienta en la formulación de políticas de desarrollo. En una segunda etapa se dio paso a cuestiones relativas a la planificación y gestión. En el momento actual, la publicación se orienta a casos de estudio en las estrategias de adaptación al cambio climático y artículos 
con cuestiones específicas de diseño hidráulico relacionadas con el rendimiento de los emisores.

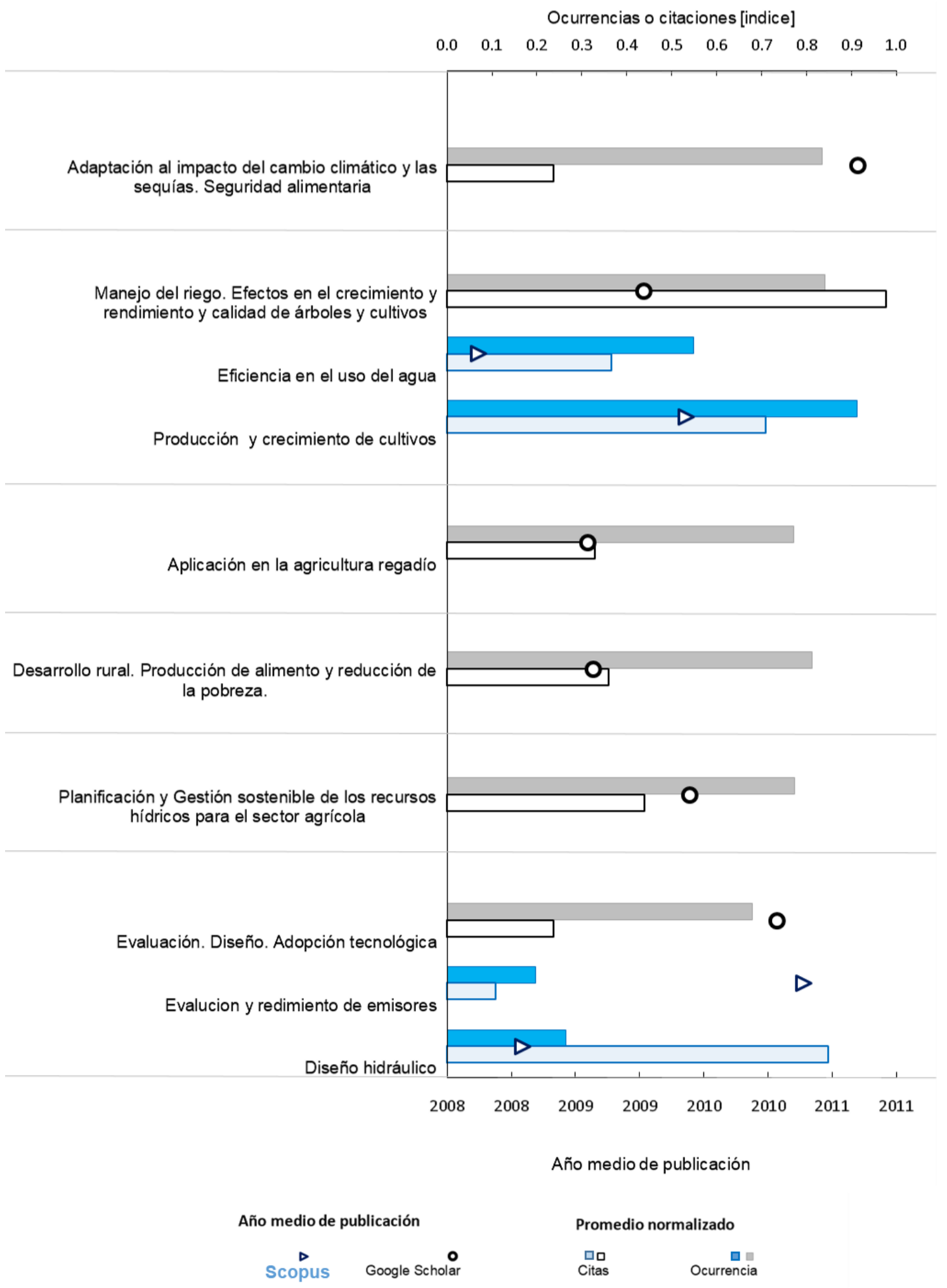

Figura 5. Evolución anual (1970-2017) de las publicaciones de micro-riego y brinzales

En cuanto a los sistemas tratados, el único que sobresale es el riego por goteo aplicado a especies propias de la arboricultura, especialmente la fruticultura, viñedos y otros productos propios de la agricultura, sin que se observe como tema destacado el 
riego de plantaciones de brinzales en los proyectos de repoblación y reforestación, ni las tecnologías emergentes que está ofreciendo el mercado para su uso en la plantación de brinzales en los proyectos de repoblación o reforestación.

\section{Discusión: Necesidades de investigación}

La revisión bibliométrica ha detectado un creciente interés por los temas de micro-riego como estrategia de racionalización del uso del agua y su potencialidad en el sector agrario. Lo señalan como un instrumento técnico de interés en la producción de alimentos para reducir la pobreza y alcanzar el objetivo de la seguridad alimentaria, especialmente en geografías con sequías meteorológicas y edáficas muy susceptibles al impacto del cambio climático, con especial énfasis en la descripción de casos de uso de la tecnología.

La evaluación del micro-riego se ha centrado principalmente en la tecnología del riego por goteo subsuperficial, aplicado a plantaciones con especies de árboles que presentan producciones de alto valor económico. Con especial interés se han tratado los temas referentes al efecto del riego sobre la cantidad y calidad de la producción. Los trabajos más recientes, en esta línea, hacen referencia a la adopción tecnológica y a las cuestiones sobre su funcionamiento hidráulico, en especial sobre el caudal emitido.

Este panorama muestra una carencia sobre el conocimiento del funcionamiento hidráulico de los sistemas de micro-riego no convencionales aplicados a la plantación de brinzales en los proyectos de repoblación forestal, muchos de los cuales no han superado la fase de diseños experimentales centrados en evaluar la supervivencia y el crecimiento de los brinzales.

La revisión sistemática muestra que el mercado del micro-riego de brinzales forestal es reciente y cómo uno de los asuntos de interés es el conocimiento del rendimiento de los emisores, base para dimensionar los sistemas de irrigación. Los datos ofrecidos por los fabricantes hacen referencia a las dimensiones y costes de los sistemas de micro-riego. Sin embargo, la información sobre el caudal emitido es escasa, a pesar de ser una de las variables necesarias para realizar el diseño del riego y uno de los temas de investigación principales en otros sistemas de riego convencionales aplicados al establecimiento de brinzales. Por este motivo la revisión que se plantea tiene por objetivo identificar el fundamento hidráulico de entrega de agua de los sistemas de riego utilizados en la plantación de brinzales y realizar una comparativa entre ellos que oriente la elección de la alternativa más adecuada. Para ello se propone en esta revisión una clasificación de las tecnologías que ofrece el mercado en base a la ecuación característica.

\section{Bibliografía}

Hirsch, J. E. (2005) An index to quantify an individual's scientific research output. Proceedings of the National academy of Sciences, 102(46): 16569-16572. doi:10.1073/pnas.0507655102

Lee CISG, Felps W, Baruch Y (2014) Toward a taxonomy of career studies through bibliometric visualization. Journal of Vocational Behavior 85 (3):339-351. doi:10.1016/j.jvb.2014.08.008 
Van Eck N, Waltman L (2007) VOS: A New Method for Visualizing Similarities Between Objects. In: Decker, R., Lenz, H.-J. (eds.), Advances in Data Analysis. Studies in Classification, Data Analysis, and Knowledge Organization. Springer Berlin Heidelberg, pp 299-306

Van Eck NJ, Waltman L (2009) How to normalize cooccurrence data? An analysis of some well-known similarity measures. Journal of the American Society for Information Science and Technology 60 (8):1635-1651. doi:10.1002/asi.21075

Waltman L, Van Eck NJ, Noyons ECM (2010) A unified approach to mapping and clustering of bibliometric networks. Journal of Informetrics 4 (4):629-635. doi:10.1016/j.joi.2010.07.002 


\section{Capítulo 4. Eficiencia técnica de los sistemas de riego de brinzales}

El mercado oferta numerosos sistemas de riego con el objetivo de evitar la reposición de plantas muertas por estrés hídrico y conseguir el establecimiento de la plantación. El presente capítulo determina la eficiencia técnica global y pura de los sistemas de riego más utilizados, mediante el método no paramétrico de análisis envolvente de datos (DEA). El método DEA se aplica tanto a los sistemas individuales de riego como a la clasificación de los mismos según su principio hidráulico de entrega de agua. Se utiliza como variable de entrada el coste unitario de instalación y como variable de salida la eficiencia de aplicación de agua, a partir de los datos obtenidos por revisión bibliográfica. Los resultados indican que existen diferencias en las eficiencias técnicas de los sistemas de riego disponibles en el mercado, señalando que los sistemas de riego convencionales presentan ineficiencias técnicas y están operando fuera de la escala del sector. La eficiencia técnica de los sistemas de micro-riego que ofrece el mercado es valiosa para orientar a los industriales e inventores en el diseño y fabricación de sus sistemas, y para los proyectistas, a los que proporciona un criterio para elegir la tecnología de riego más eficiente técnicamente en el establecimiento de masas arboladas y/o arbustivas. 
Tabla 1. Listado de siglas utilizadas en el capítulo

\begin{tabular}{|c|c|}
\hline Símbolo & Significado \\
\hline $\mathrm{BCC}$ & Modelo de Banker et al. (1984) para el cálculo de la eficiencia técnica pura (PTE) \\
\hline CCR & Modelo de Charnes et al. (1978) para el cálculo de la eficiencai técncia global (OTE) \\
\hline CRS & Rendimientos de escala constantes \\
\hline$d$ & Coste unidatio del sistema de irrigación \\
\hline DEA & Análisis envolvente de datos \\
\hline DMU & Unidad de decisión \\
\hline$E_{a}$ & Eficiencia de aplicación de agua \\
\hline IRS & $\begin{array}{l}\text { Modelo de Banker et al. (1984) para el cálculo de rendimientos de escala no } \\
\text { decrecientes (NDRS) }\end{array}$ \\
\hline$m$ & Número de variables de entrada \\
\hline$n_{D M U h}$ & Número de unidades evaluadas por fundamento hidráulico \\
\hline$n_{D M U w}$ & Número de unidades evaluadas por sistema de riego \\
\hline NDRS & Índice de rendimientos de escala no decrecientes \\
\hline OTE & Eficiencia técnica global \\
\hline PET & Tereftalato de polietileno \\
\hline PTE & Eficiencia técnica pura \\
\hline$s$ & Número de variables de salida \\
\hline SE & Eficiencia de escala \\
\hline VRS & Rendimientos de escala variable \\
\hline
\end{tabular}




\section{Introducción}

El estudio del efecto del riego sobre la supervivencia de los brinzales, desde la plantación hasta que alcanzan la autonomía hídrica, es un tema central de estudio en el micro-riego de brinzales. Los ensayos experimentales (p. ej. Rey, 1998; Badía et al., 2007; Al-Homaid y Khan, 1994; Alrababah et al., 2008; Becerra et al., 2013) están proporcionando evidencias de la utilidad de la irrigación para lograr el éxito inicial de la plantación en tierras áridas. Para trasladar estas experiencias a escala monte, y en concreto en al ámbito de la forestación de zonas áridas, el mercado ofrece diversas tecnologías de riego no convencional dirigidas a conseguir el establecimiento de las masas (Bainbridge et al., 1995; Bainbridge, 2002; Martínez de Azagra y Del Río, 2012).

Aunque se están produciendo avances en el conocimiento del funcionamiento individual de estas tecnologías (Bainbridge, 2007; Martínez de Azagra y Del Río, 2015), la información todavía es parcial e incompleta. La revisión de los sistemas de riego no convencional disponibles en el mercado muestra que, aún identificado el proceso hidráulico subyacente en cada sistema, no se dispone de valores contrastados de la tasa de entrega de agua (Martínez de Azagra y Del Río, 2017). Esta falta de información impide determinar la eficiencia de aplicación de agua con exactitud. La solución de acudir a valores bibliográficos ofrece valores orientativos, pero genera incertidumbre en el dimensionamiento del riego. Desde una perspectiva empresarial, la industria es emergente, con numerosos prototipos que están comenzando su comercialización (Martínez de Azagra y Del Río, 2012). Sin embargo, nos encontramos ante un mercado alejado de una masa crítica de usuarios. Esta circunstancia provoca un freno del desarrollo empresarial de cara a que pueda implantar procesos de fabricación a una escala que abarate su coste.

Ambas cuestiones, la eficiencia de aplicación de agua y su coste, proyectan dudas sobre la viabilidad técnica y económica del micro-riego de brinzales frente a los sistemas de riego tradicionales u otras prácticas de gestión de las marras (Bainbridge, 2007; Del Río et al., 2018). El desconocimiento aumenta la abstención ante las decisiones arriesgadas (Jensen, 1982). Esta situación es uno de los principales motivos que explica la dificultad de abordar las tareas de elección de los sistemas más apropiados en el diseño de las plantaciones y lograr criterios que orienten las estrategias de diseño y fabricación de estos sistemas, a pesar de las demostraciones prácticas de su utilidad para reducir la mortalidad de las plantas por causa del estrés hídrico (p. ej. Bean et al., 2004; Squeo et al., 2007).

A pesar de estas carencias, el estado de conocimiento actual puede ser aprovechado para conseguir una visión global del sector del riego de brinzales y orientarse en la variedad y multiplicidad de sistemas ofertados actualmente por la industria. Se puede conocer la restricción tecnológica que define la frontera de posibilidades de producción mediante métodos cuantitativos como el análisis envolvente de datos (DEA) (Charnes et al., 1978). El método DEA es muy flexible puesto que no realiza supuestos iniciales sobre la forma de la frontera y permite múltiples 
entradas y salidas (Díaz-Balteiro et al., 2006). Una vez definida la frontera, el cálculo de indicadores mide la ineficacia tecnológica global y pura de cada sistema a partir de la distancia a la frontera de producción. Con este resultado se puede determinar la cercanía de cada tecnología a las más eficientes del mercado y comparar qué posición ocupa cada sistema de micro-riego de brinzales dentro del sector del riego.

La metodología de DEA se ha utilizado para evaluar la eficiencia técnica de la producción agrícola obtenida por las explotaciones agrarias de regadío o en las zonas regables a partir, principalmente, de su dotación de riego (Ntantos et al., 2010; Yilmaz y Harmancioğlu, 2007; Pereira y Marques, 2017). La finalidad de estos análisis ha sido variada: i) Clasificar explotaciones y áreas (Rodríguez-Díaz et al., 2004), ii) Obtener recomendaciones de planificación o gestión (Olmedo et al., 2017), iii) Identificar los factores explicativos de la ineficiencia (Naceur y Mongi 2013; Mahdhi et al., 2014) y iv) Evaluar el impacto en la eficiencia de variaciones en los insumos (Wang, 2010), o en su percepción (Tang et al., 2015). Para los autores de estos trabajos la tecnología del riego es el factor de producción que proporciona el insumo, es decir, la dotación de riego. No evalúan por tanto la eficiencia tecnológica de los sistemas de riego que oferta el mercado, sino la eficiencia de las explotaciones agrarias en su uso.

A pesar de estos trabajos en el ámbito del regadío agrícola, la utilización DEA en el ámbito forestal es incipiente (p. ej. Díaz-Balteiro et al., 2006); apenas un 0,86\% del total de publicaciones que usan DEA (Liu et al., 2013) y no se conocen ejemplos en la literatura de su utilización para evaluar el riego, $\mathrm{u}$ otros cuidados culturales destinados a conseguir la supervivencia de brinzales en el establecimiento de plantaciones.

El objetivo del presente artículo es evaluar la eficiencia técnica de los sistemas de micro-riego utilizados en el establecimiento de brinzales con el fin de compararlos y describir el estado actual de la tecnología tomando como base el DEA.

\section{Material y métodos}

\subsection{El método de análisis envolvente de datos}

El DEA construye, de forma no paramétrica, las fronteras resultantes de la combinación de los insumos y el desempeño de las unidades de decisión (DMU). A partir de la distancia de cada DMU a las fronteras, se obtienen los índices de eficiencia tecnológica. Las dos fronteras que define el DEA son la de rendimientos constantes de escala y la de rendimientos variables de escala. La eficiencia técnica global (OTE) es la eficiencia técnica con rendimientos de escala constantes (CRS); mide la capacidad óptima de la industria para utilizar una cantidad factible de insumos en la producción y es calculada mediante el modelo CCR (Charnes et al., 1978).

Con el fin de conocer el origen de la ineficiencia, se desglosa la eficiencia técnica global (OTE) en sus componentes: la eficiencia técnica pura (PTE) y la eficiencia de escala (SE).

$$
O T E=P T E \cdot S E \quad[1]
$$


La eficiencia técnica pura (PTE) es la eficiencia técnica con rendimientos de escala variable (VRS). Mide la capacidad de la industria para organizar los insumos de manera óptima en el proceso de producción y es calculada con el modelo BCC (Banker et al., 1984).

La eficiencia de escala (SE) es $S E=O T E / P T E$ y mide el grado en que la DMU opera en la dimensión, condiciones o tamaño óptimo. Este índice responde a la cuestión de si las DMU deben reducir o aumentar el consumo de insumos.

La metodología DEA usa el índice de rendimientos de escala no decrecientes (NDRS) con el fin de determinar si la DMU está operando con rendimientos crecientes o decrecientes de escala, el cual se calcula mediante el modelo IRS (Banker et al., 1984).

\subsection{Las variables de entrada y salida}

Para comparar la eficiencia técnica, tanto de los sistemas de riego como de su fundamento hidráulico mediante el método DEA, se deben elegir variables de entrada (insumos) y de salida (desempeño) representativas. En este caso se ha elegido una variable de entrada $(m=1)$ y una de salida $(s=1)$ dada la escasez de datos sobre el sector. Los datos seleccionados para describir las tecnologías del sector (Tabla 2) se han obtenido a partir de las revisiones bibliográficas del sector del riego de brinzales del capítulo 1, incluyendo sistemas tradicionales de riego y sistemas de micro-irrigación.

El coste unitario del sistema de irrigación considera su instalación (d), en unidades $€$ planta $^{-1}$. Esta variable es el insumo y resume el esfuerzo productivo de la industria en el diseño y fabricación de los sistemas de riego. Entre las múltiples variables utilizadas para medir el desempeño del riego, se ha elegido la eficiencia de aplicación de agua $\left(E_{a}\right)$, adimensional (Jensen, 2007). Ea es el agua transpirada por el brinzal entre agua aplicada por el sistema de riego (por el emisor) y el principal parámetro empleado en el diseño y del riego, válido para evaluar todos los métodos de irrigación (Jurriens et al., 2001; Michael, 2009).

\subsection{Los niveles de decisión (DMU)}

Con el fin de proporcionar una visión amplia del sector del riego de brinzales se han adoptado dos niveles de análisis: el sistema de riego y su fundamento hidráulico. Se han seleccionado sistemas convencionales y sistemas de micro-riego debido a que el objetivo del análisis es ofrecer una visión amplia de las todas las posibles opciones de riego de los brinzales. El número total de unidades evaluadas es $n_{D M U w}=20$. 
Tabla 2. Costes y eficacia de aplicación de agua de los sistemas de riego de brinzales y de su fundamento hidráulico

\begin{tabular}{|c|c|c|c|c|}
\hline $\begin{array}{l}\text { Unidad de toma de decisión } \\
\text { DMUw }\end{array}$ & $\begin{array}{l}\text { Fundamento } \\
\text { hidráulico }\end{array}$ & $\begin{array}{c}\text { Coste del } \\
\text { sistema de } \\
\text { irrigación } \\
d \\
{\left[€ \cdot \text { planta-1 }^{-1} \text { (8) }\right.}\end{array}$ & $\begin{array}{l}\text { Eficiencia de } \\
\text { aplicación Ea } \\
\text { [adim.] (2) }\end{array}$ & Fuente $E a$ \\
\hline \multicolumn{5}{|c|}{ Sistemas tradicionales (Conventional systems) } \\
\hline $\begin{array}{l}\text { Gravedad } \\
\text { (Surface irrigation) }\end{array}$ & $\begin{array}{l}\text { Infiltración } \\
\text { (Infiltration) }\end{array}$ & 10,00 & $(0,55,0,66) ; 0,60$ & $(3)(4)(5)$ \\
\hline $\begin{array}{l}\text { Aspersión } \\
\text { (Sprinkler irrigation) }\end{array}$ & & 15,00 & $(0,67,0,81) ; 0,74$ & $(3)(4)(5)(6)$ \\
\hline $\begin{array}{l}\text { Microaspersión } \\
\text { (Micro-sprinkler irrigation) }\end{array}$ & & 25,00 & $(0,84,0,90) ; 0,87$ & (4) \\
\hline $\begin{array}{l}\text { Goteo superficial } \\
\text { (Drip irrigation) }\end{array}$ & $\begin{array}{l}\text { Presión de trabajo } \\
\text { (Working pressure) }\end{array}$ & 40,00 & $(0,85,0,95) ; 0,90$ & $(3)(4)(5)(7)$ \\
\hline $\begin{array}{l}\text { Goteo subterráneo } \\
\text { (Subsurface drip irrigation) }\end{array}$ & & 50,00 & 0,95 & $(4)$ \\
\hline $\begin{array}{l}\text { Autombomba con maguera (1) } \\
\text { (Irrigation of tree basins with hose) }\end{array}$ & & 2,67 & 0,50 & (9) \\
\hline \multicolumn{5}{|c|}{ Micro-irrigation } \\
\hline $\begin{array}{l}\text { Tubos verticales } \\
\text { (Deep pipes) }\end{array}$ & \multirow{5}{*}{$\begin{array}{l}\text { Infiltración } \\
\text { (Infiltration) }\end{array}$} & 0,93 & 0,95 & \multirow{14}{*}{ (10) } \\
\hline Irrigasc & & 3,50 & 0,95 & \\
\hline Buried diffuser ${ }^{\circledR}$ & & 6,00 & 0,95 & \\
\hline $\begin{array}{l}\text { Tubos de drenaje } \\
\text { Horizontal perforated pipes }\end{array}$ & & 2,47 & 0,85 & \\
\hline Buried stones pocket & & 2,60 & 0,95 & \\
\hline $\begin{array}{l}\text { Tarros de barro } \\
\text { (Buried pitchers) }\end{array}$ & \multirow{3}{*}{$\begin{array}{c}\text { Diferencia en potencial } \\
\text { hídrico } \\
\text { (Difference in water } \\
\text { potential) }\end{array}$} & 2,24 & 0,95 & \\
\hline $\begin{array}{l}\text { Cápsulas porosas } \\
\text { (Porous capsules) }\end{array}$ & & 1,07 & 0,95 & \\
\hline RIES bottles & & 2,90 & 0,95 & \\
\hline Microreservoir ${ }^{\circledR}$ & $\begin{array}{l}\text { Presión de trabajo } \\
\text { (Working pressure) }\end{array}$ & 6,30 & 0,95 & \\
\hline $\begin{array}{l}\text { Botellas PET con mechas } \\
\text { (PET bottles with wicks) }\end{array}$ & \multirow{4}{*}{$\begin{array}{l}\text { Capilaridad } \\
\text { (Capillarity) }\end{array}$} & 0,79 & 0,95 & \\
\hline $\begin{array}{l}\text { Tarros de barro con mechas } \\
\text { (Pitchers with wicks) }\end{array}$ & & 1,20 & 0,95 & \\
\hline Eco Bag ${ }^{\circledR}$ & & 4,11 & 0,95 & \\
\hline Waterboxx ${ }^{\circledR}$ & & 4,89 & 0,95 & \\
\hline Konkom & $\begin{array}{l}\text { Evaporación y } \\
\text { condesación } \\
\text { (Evaporation and } \\
\text { condensation) } \\
\end{array}$ & 0,86 & 0,95 & \\
\hline
\end{tabular}

Notas:

(1) Riego mediante manguera acoplada a autobomba sobre tractor agrícola (con cuba de 10.000 L) o camión forestal de extinción de incendios

(2) Valores promedio de las fuentes bibliográficas

(3) Keller (1995, 1996), Fuentes y Cruz (1990), Pascual (2008)

(4) Irmak et al. (2011)

(5) Brouwer et al. (1989)

(6) Tarjuelo (2005)

(7) Arviza (1996)

(8) Fuentes de los costes: Ariel (2016), Alarcón et al. (2016), Bainbridge (2007), Martinez de Azagra y Del Río (2012), e información facilitada por los fabricantes de cada producto

(9) Estimado por los autores

(10) Bainbridge (2007); Martinez de Azagra y Del Río (2012) e información facilitada por los fabricantes de cada producto 
El segundo nivel de análisis es el fundamento hidráulico que describe el proceso físico implicado en la entrega de agua. Los datos se obtienen mediante la media de los sistemas de riego que comporten el mismo fundamento hidráulico (Tabla 3). El número de unidades es $n_{D M U h}=5$.

Tabla 3. Costes y eficacia de aplicación promedio según el fundamento hidráulico

\begin{tabular}{|c|c|c|}
\hline $\begin{array}{l}\text { Unidad de toma de decisión } \\
\text { DMUh }\end{array}$ & $\begin{array}{c}\text { Coste del sistema de } \\
\text { irrigación } \\
d \\
{\left[€ \cdot \text { plant }^{-1}\right]}\end{array}$ & $\begin{array}{c}\text { Eficiencia de aplicación } \\
\qquad E a \\
\text { [adim.] }\end{array}$ \\
\hline $\begin{array}{l}\text { Evaporación y condensación } \\
\text { Evaporation and condensation } \\
\text { Capilaridad }\end{array}$ & 0,86 & 0,95 \\
\hline Capillarity & 2,75 & 0,95 \\
\hline $\begin{array}{l}\text { Diferencia de potencial hídrico } \\
\text { Difference in water potential } \\
\text { Infiltración } \\
\text { Infiltration }\end{array}$ & 2,07 & 0,95 \\
\hline $\begin{array}{l}\text { Sistemas con presión de trabajo } \\
\text { Working pressure }\end{array}$ & 23,16 & 0,82 \\
\hline
\end{tabular}

\subsection{Orientación y cálculo del modelo}

El análisis DEA planteado en este trabajo está orientando al insumo. Este enfoque (Charnes et al., 1981) establece que los costes son controlables por la industria, mientras que la eficiencia de aplicación de agua $\left(E_{a}\right)$ es un factor no controlable característico del estado actual de la tecnología de cada sistema de riego. De esta manera, la eficiencia técnica global mide qué sector de la industria de fabricación de sistemas de riego consigue la producción de sistemas de riego con un nivel dado de $E_{a}$ con el mínimo coste $d$.

La técnica DEA ha sido ampliamente descrita por la literatura (Charnes et al., 1994; Coelli et al., 2005). Los índices CRS, VRS con valor igual a uno indican que el DMU se encuentra situado en esa frontera de eficiencia. El valor complementario de los índices, 1-CRS, 1-VRS, señala cuál debe ser el esfuerzo que debe realizar el DMU para alcanzar la frontera y ser eficiente. El IRS superior a la unidad indica si el sistema está operando con rendimientos crecientes de escala.

Los cálculos de DEA se han realizado mediante el software OSDEA (Virtos, H. Released 2016. Open Source DEA, Version 0.2., http://opensourcedea.org). A partir de los índices anteriores se identifican los grupos de mejora analizando los cuadrantes del grafico CRS-VRS (Fernández y Florez, 2006) según los criterios expuestos en la tabla 4. 
Tabla 4. Criterios de clasificación de los grupos de mejora de los DMU de los sistemas de riego

\begin{tabular}{ccc}
$\begin{array}{c}\text { Rango según valor } \\
\text { del índice } \\
\text { complementario }\end{array}$ & Competitividad & 1-SE \\
\hline 0 & Eficiente & Sobredimensionamiento \\
$0,01-25$ & Alta & Muy Bajo \\
$25,01-50$ & Media & Bajo \\
$50,01-75$ & Baja & Medio \\
$75,01-95$ & Muy Baja & Alto \\
95,01 & No competitivos & Fuera de escala \\
\hline
\end{tabular}

\section{Resultados}

Las fronteras se han trazado en el plano de las variables $d$ y $E_{a}$. En la figura 1 se observa cómo la ineficiencia técnica global (frontera $C R S$ ) se debe a la ineficiencia técnica pura (frontera VRS) siendo mayor que el efecto de la eficiencia de escala de la fabricación de los sistemas de riego. 


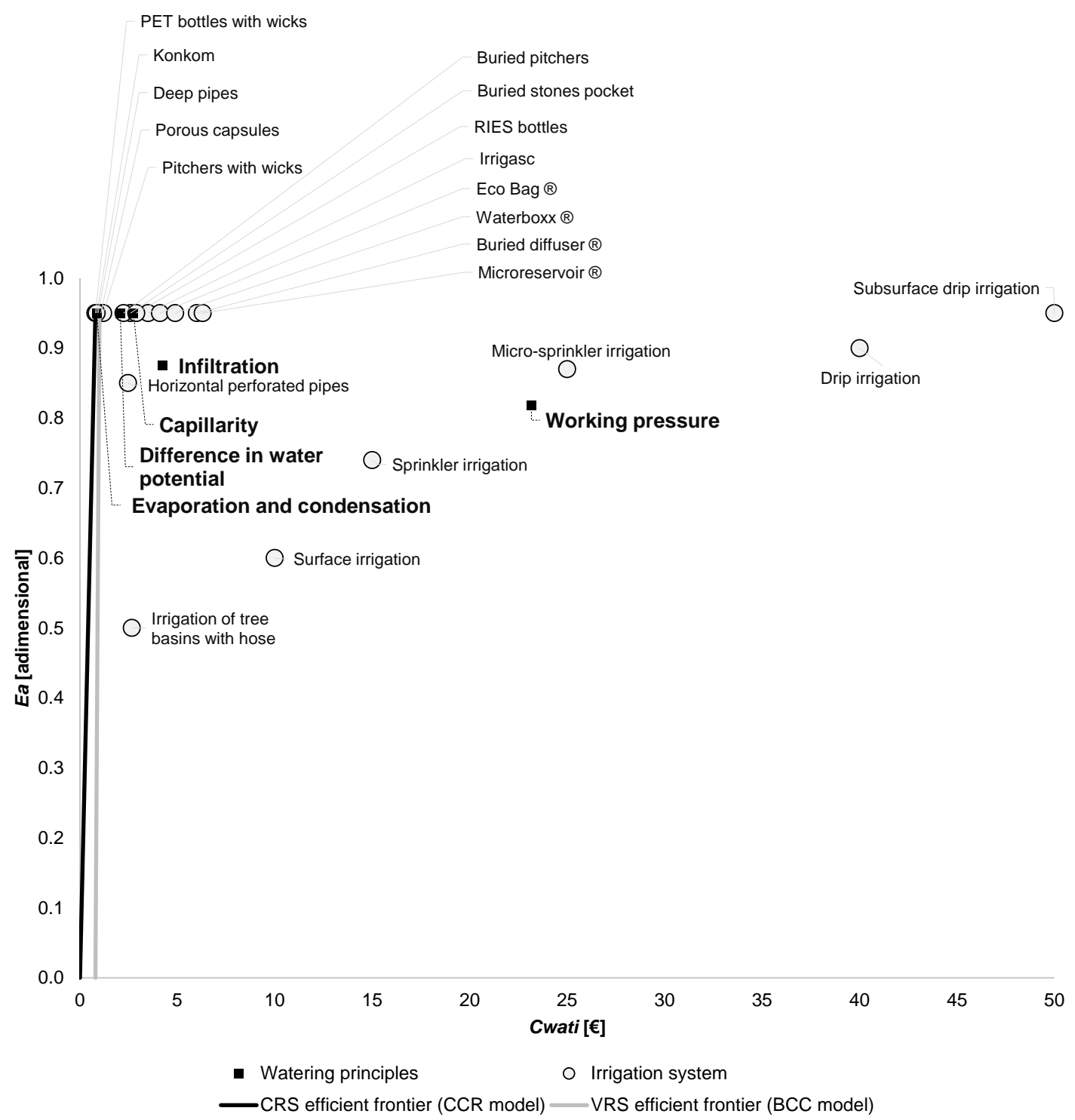

Figura 1. Frontera de posibilidades de producción de los sistemas de riego y sus principios hidráulicos

Los resultados de los índices $V R S, C R S$ para cada DMU, tanto para los sistemas de riego como para sus fundamentos hidráulicos, están recogidos en la figura 2 . En ella se observa que la DMU eficiente que se toma como punto de referencia $(C R S=V R S=1)$ es el sistema «PET, botellas con mechas» y el fundamento hidráulico de entrega de agua de «Evaporación y condensación». A la eficiencia de estas unidades deberán aproximarse las demás, modificando su coste. 


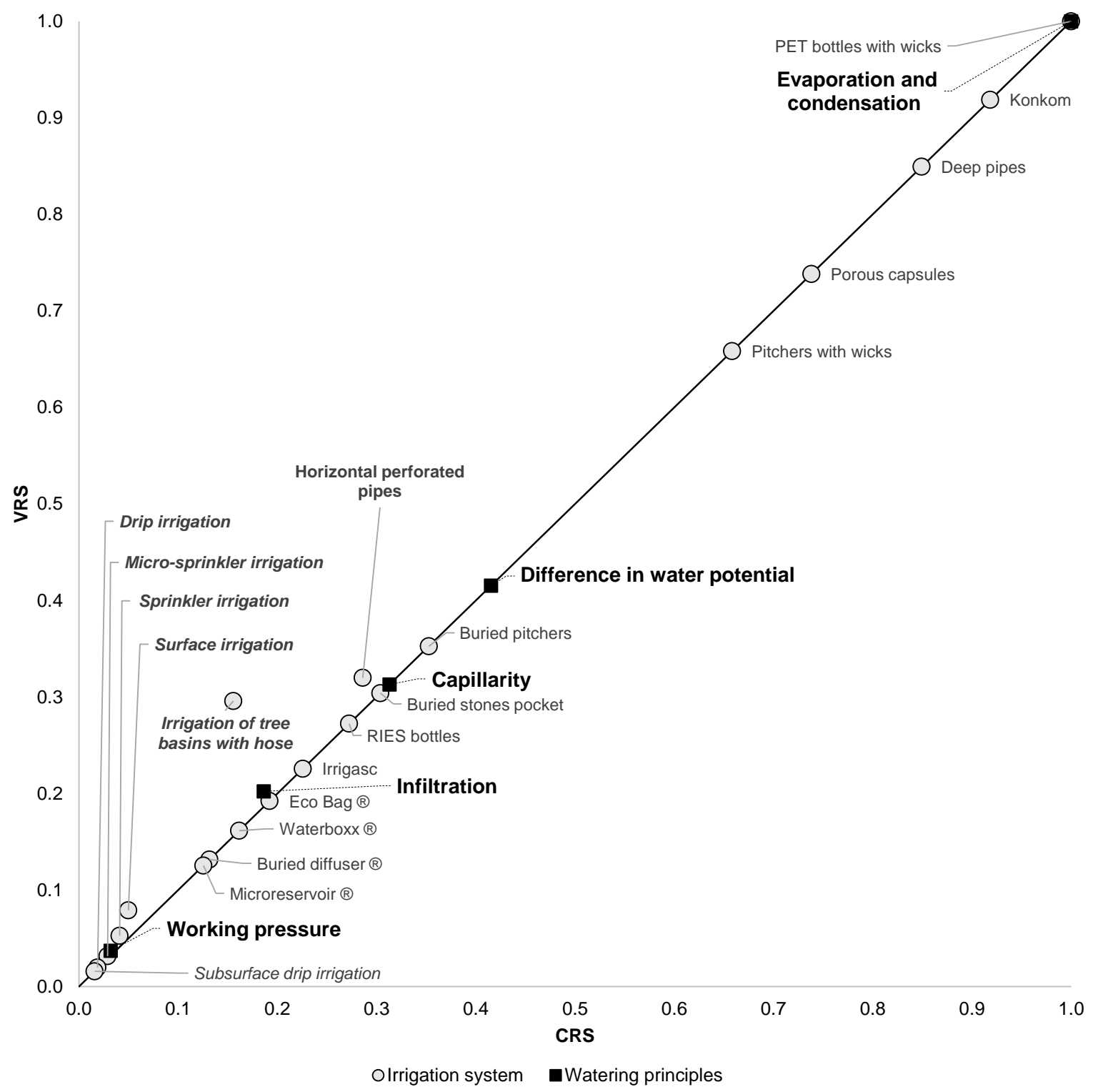

Figura 2. Índices VRS y CRS para cada sistema de riego y fundamento hidráulico

El resto de DMU son ineficientes técnicamente, de manera global y pura. Los sistemas y fundamentos hidráulicos situados en la diagonal representada en la figura 2 tienen rendimientos de escala constantes $(C R S=V R S \diamond 1$ y $S E=1)$. Los sistemas y principios que forman parte de este grupo están aprovechando las economías de escala, aunque la gestión del proceso productivo, comercialización e instalación de estos sistemas de riego no consigue utilizar de forma óptima los factores productivos para obtener un precio óptimo. En este grupo la comparación por cuadrantes permite observar que no todos los DMU debe realizar el mismo esfuerzo de reducción del coste para ser eficientes. Los sistemas concentrados en la esquina superior derecha del gráfico son los que tienen mayor eficiencia técnica global y de escala y, por lo tanto, son los que deben realizar menor reducción de costes; en este grupo se encuentran los sistemas ineficientes, pero altamente competitivos, con esfuerzos de mejora del 1-CRS $\leq 15,02 \%$ 
y los ineficientes medianamente competitivos, para los que se obtienen valores 1-CRS $\leq$ $34,2 \%$. Los sistemas situados en el cuadrante de la esquina inferior izquierda, deben realizar un importante esfuerzo de mejora, en este caso superior a (1-CRS $\geq 58,4 \%$ ). A medida que va aumentado la distancia en la diagonal del DMU al sistema de eficiencia óptimo de referencia, la gestión debe reducir mayor cantidad de insumos. En esta situación se encuentran los sistemas ineficientes cuya competitividad es baja, con reducciones que alcanzan el $(1-C R S<72,7 \%)$, los ineficientes con competitividad muy baja, para los que se hemos encontrado reducciones de hasta el $(1-C R S<87,4 \%)$. El grupo de los sistemas no competitivos tiene que realizar reducciones superiores o iguales al (1$C R S \geq 95,0 \%$ ).

Los sistemas que están fuera de la diagonal operan en una escala distinta del resto de sistemas de riego. La ineficiencia técnica global que presentan $(C R S<1)$ es en parte debida a la ineficiencia técnica pura $(V R S<1)$ y en parte a la ineficiencia de escala $(S E<$ 1). En el caso analizado, todos los DMU tienen rendimientos de escala crecientes (IRS < 1). La ineficiencia de escala de aquellos sistemas próximos a la diagonal aconseja ajustes del tamaño inferiores a $(1-S E<22,1 \%)$ debido a que su sobredimensionamiento es muy bajo. Los sistemas más alejados de la diagonal son los que presentan mayor grado de sobredimensionamiento. En este grupo se encuentra el riego convencional a manta y el sistema de manguera y autobomba, para los que hemos hallado las mayores necesidades de ajuste que alcanzan el $(1-S E<47,4 \%)$.

En la tabla 5 se ordenan los DMU según el grupo de mejora. 
Tabla 5. Tabla clasificatoria de los sistemas de riego y de su fundamento hidráulico (en negrita), para micro-riego y sistemas convencionales (en cursiva) según su eficiencia técnica global y pura, y grupos de mejora

\begin{tabular}{|c|c|c|c|c|c|}
\hline DMU & 1-CRS & 1-VRS & $1-S E$ & IRS & Grupo de mejora \\
\hline PET bottles with wicks & 0,000 & 0,000 & 0,000 & & Eficientes \\
\hline $\begin{array}{l}\text { Evaporation and } \\
\text { condensation }\end{array}$ & 0,000 & 0,000 & 0,000 & & Eficientes \\
\hline Konkom & 0,081 & 0,081 & 0,000 & & Competitividad alta \\
\hline Deep pipes & 0,151 & 0,151 & 0,000 & & Competitividad alta \\
\hline Porous capsules & 0,262 & 0,262 & 0,000 & & Competitividad media \\
\hline Pitchers with wicks & 0,342 & 0,342 & 0,000 & & Competitividad media \\
\hline $\begin{array}{c}\text { Difference in water } \\
\text { potential }\end{array}$ & 0,585 & 0,585 & 0,000 & & Competitividad baja \\
\hline Buried pitchers & 0,647 & 0,647 & 0,000 & & Competitividad baja \\
\hline Capillarity & 0,687 & 0,687 & 0,000 & & Competitividad baja \\
\hline Buried stones pocket & 0,696 & 0,696 & 0,000 & & Competitividad baja \\
\hline Horizontal perforated pipes & 0,714 & 0,680 & 0,105 & 0,320 & $\begin{array}{l}\text { Competitividad baja } \\
\text { Sobredimensionamiento muy bajo }\end{array}$ \\
\hline RIES bottles & 0,728 & 0,728 & 0,000 & & Competitividad baja \\
\hline Irrigasc & 0,774 & 0,774 & 0,000 & & Competitividad muy baja \\
\hline Eco Bag ${ }^{\circledR}$ & 0,808 & 0,808 & 0,000 & & Competitividad muy baja \\
\hline Infiltration & 0,814 & 0,798 & 0,079 & 0,202 & $\begin{array}{l}\text { Competitividad muy baja } \\
\text { Sobredimensionamiento muy bajo }\end{array}$ \\
\hline Waterboxx ${ }^{\circledR}$ & 0,838 & 0,838 & 0,000 & & Competitividad muy baja \\
\hline $\begin{array}{c}\text { Irrigation of tree basins with } \\
\text { hose }\end{array}$ & 0,844 & 0,704 & 0,474 & 0,296 & $\begin{array}{l}\text { Competitividad muy baja } \\
\text { Sobredimensionamiento bajo }\end{array}$ \\
\hline Buried diffuser ${ }^{\circledR}$ & 0,868 & 0,868 & 0,000 & & Competitividad muy baja \\
\hline Microreservoir ${ }^{\circledR}$ & 0,875 & 0,875 & 0,000 & & Competitividad muy baja \\
\hline Surface irrigation & 0,950 & 0,921 & 0,368 & 0,079 & $\begin{array}{l}\text { No competitivos } \\
\text { Sobredimensionamiento bajo }\end{array}$ \\
\hline Sprinkler irrigation & 0,959 & 0,947 & 0,221 & 0,053 & $\begin{array}{l}\text { No competitivos } \\
\text { Sobredimensionamiento muy bajo }\end{array}$ \\
\hline Working pressure & 0,968 & 0,963 & 0,139 & 0,037 & $\begin{array}{l}\text { No competitivos } \\
\text { Sobredimensionamiento muy bajo }\end{array}$ \\
\hline Micro-sprinkler irrigation & 0,971 & 0,968 & 0,084 & 0,032 & $\begin{array}{l}\text { No competitivos } \\
\text { Sobredimensionamiento muy bajo }\end{array}$ \\
\hline Drip irrigation & 0,981 & 0,980 & 0,053 & 0,020 & $\begin{array}{l}\text { No competitivos } \\
\text { Sobredimensionamiento muy bajo }\end{array}$ \\
\hline Subsurface drip irrigation & 0,984 & 0,984 & 0,000 & & No competitivos \\
\hline
\end{tabular}

\section{Discusión}

Para proporcionar criterios de decisión sobre la oferta de tecnologías es útil acudir al concepto de restricción tecnológica, cuyo extremo define la frontera de posibilidades de producción empírica de los sistemas de riego disponible en el mercado. La frontera implica que solo existe un conjunto de combinaciones viables de insumos para fabricar sistemas de riego de brinzales que proporcionan una solución técnicamente factible. En esa frontera se encuentran los sistemas eficientes, es decir, aquellos que transforman de forma óptima los costes en sistemas de riego con una determinada eficiencia de aplicación de agua. La dificultad para identificar la frontera de los sistemas 
de irrigación de brinzales hace que sea de interés la utilización de métodos no paramétricos como el DEA, para evaluar la eficiencia económica y tecnológica. Las DMU seleccionadas cumplen con las siguientes condiciones de homogeneidad: i) están involucradas en el mismo proceso, ii) las mismas medidas de eficiencia se aplican a todas las DMU, y iii) todas las DMU funcionan bajo las mismas condiciones (Haas y Murphy, 2003). La capacidad de discriminación del DEA debe cumplir con las reglas de suficiencia de la dimensión, debido a que cuanto mayor sea el número de variables incluidos en el análisis, menor será el nivel de discriminación (Dyson et al., 2001). En la literatura se han propuesto reglas con distinto nivel de exigencia para evitar esta limitación: $n_{D M U} \geq 2 \cdot(s+m)$ (Golany y Roll, 1989), $n_{D M U} \geq 3 \cdot(s+m)$ (Charnes et al., 1994), $n_{D M U} \gg(s \cdot m) \geq 2$ (Murias et al., 2008). Estas condiciones se verifican en el primer nivel de análisis, $n_{D M U w}=20>2>4>6$ y parcialmente en el fundamento hidráulico de entrega de agua $n_{D M U h}=5>2>4<6$.

El análisis DEA planteado cumple por lo tanto con los requisitos formales de la metodología. Sin embargo, los resultados numéricos concretos de este trabajo hay que considerarlos orientativos debido a que el DEA tiene dos limitaciones. La primera es que la eficiencia técnica depende de la exactitud de las medidas de los insumos y desempeños; si existe incertidumbre en los datos se pueden clasificar unidades como ineficientes cuando realmente no lo son (Martín, 2007). En el caso planteado, existe una incertidumbre del desempeño $E_{a}$, debido a que se han utilizado los valores bibliográficos disponibles. Futuros trabajos experimentales que concreten el valor de $E_{a}$ permitirán una clasificación más exacta del valor de la eficiencia técnica global y pura de los sistemas de riego. La segunda limitación es que la variable de entrada que se ha utilizado es un coste unitario. Esta aproximación es útil porque sintetiza la facilidad de manejo de la tecnología y el precio del producto en una sola variable; sin embargo, al no desglosar los factores de producción o las etapas de comercialización, no proporciona indicaciones detalladas sobre la mejora de la gestión de los recursos concretos empleados por la industria.

A pesar de las dos limitaciones anteriores, la aplicación del modelo DEA es de utilidad para identificar el panorama y estado actual de la tecnología del riego de brinzales y ofrecer recomendaciones de mejora, debido a que la alta disparidad en los resultados obtenidos (Figura 2) permite diferenciar nítidamente la ineficiencia global técnica.

En la literatura está bien establecido (Seckler, 1999; Yigezu et al., 2013) que la eficiencia de aplicación de agua (Israelsen 1932, 1950; Keller y Keller, 1995; Keller, 1996) no es sinónimo de la eficiencia técnica (Farrell, 1957). Este es el motivo por el que las buenas prácticas en el regadío agrícola, recomendadas a partir del DEA, proponen la utilización de sistemas de riego localizado con alta eficiencia de aplicación, junto con otras medidas complementarias como son la capitación de los agricultores en su uso, para conseguir una elevada eficiencia técnica (Pereira y Marques, 2017). Los resultados del presente trabajo, aplicados al micro-riego con un enfoque especial hacia la 
reforestación de zonas áridas, guardan consonancia con el de estos autores. Los grupos de mayor eficiencia de aplicación de agua (competitividad alta o media) son ineficientes técnicamente, no por una cuestión de escala, sino por un exceso de precios que obliga a mejoras en la gestión para lograr una contracción de los costes. El problema de la escala comienza a aparecer en sistemas ineficientes con muy baja o nula competitividad.

En el caso de los sistemas tradicionales de irrigación, los recursos disponibles para su fabricación están sobredimensionados para la Ea que proporcionan. Los esfuerzos de mejora, tanto en escala como en eficiencia técnica, muestran que su adaptación al riego de brinzales sea inalcanzable frente a la eficiencia lograda por otros sistemas de riego más específicos.

El método DEA muestra que existen sistemas más cercanos a la eficiencia técnica que los sistemas de las tecnologías patentadas. Este resultado abre las puertas a la utilización del riego de brinzales en los ámbitos de la intensificación sostenible agraria (Pretty, 1997), la intensificación ecológica (Doré et al., 2011; Petersen y Snapp, 2015) y de la agricultura climatológicamente inteligente de países en vías de desarrollo dirigidos a pequeños productores en economías familiares con dificultad de acceso a recursos financieros y a mercados donde sea posible adquirir estos sistemas.

La eficiencia técnica incrementa la información disponible sobre el sector del riego de brinzales, el acceso a la información sobre la tecnología apropiada y al uso eficiente de los recursos. Estos tres indicadores son utilizados habitualmente en la evaluación de la intensificación sostenible agraria (Mahon et al., 2017; Smith et al., 2017), contribuyen positivamente a reducir las barreras de adopción tecnológica (Dethier y Effenberger, 2012) e incrementan la velocidad de adopción tecnológica (Alcón et al., 2011). Sin embargo, no puede ser el único criterio de decisión para determinar su posible aplicación; en el caso de repoblaciones forestales, cuestiones selvícolas pueden matizar la elección (Martínez de Azagra y Del Río, 2012; Del Río et al., 2018).

\section{Bibliografía}

Alarcón J, Garrido A, Juana L (2016) Modernization of irrigation systems in Spain: review and analysis for decision making. International Journal of Water Resources Development 32:442-458. doi:10.1080/07900627.2015.1123142

Alcón F, de Miguel MD, Burton M (2011) Duration analysis of adoption of drip irrigation technology in southeastern Spain. Technological Forecasting and Social Change 78:991-1001. doi:10.1016/j.techfore.2011.02.001

Al-Homaid N, Khan MH (1994) Performance of Prosopis juliflora in different geomorphic units within a sandy desert ecosystem. Arid Soil Research and Rehabilitation 8:155-160. doi:10.1080/15324989409381389

Alrababah MA, Bani-Hani MG, Alhamad MN, Bataineh MM (2008) Boosting seedling survival and growth under semi-arid Mediterranean conditions: Selecting appropriate species under rainfed and wastewater irrigation. Journal of Arid Environments 72:1606-1612. doi:10.1016/j.jaridenv.2008.03.013

Ariel D (2016) Drip vs pivot-An economic comparison of irrigation systems based on the whole-farm budget model of sugarcane crops. Woda-Środowisko-Obszary Wiejskie 16:5-16

Arviza J (1996) Riego localizado. Universidad Politécnica de Valencia, Valencia, Spain 
Badía D, Valero R, Gracia A, Martí C, Molina F (2007) Ten-Year Growth of Woody Species Planted in Reclaimed Mined Banks with Different Slopes. Arid Land Research and Management 21:67-79. doi:10.1080/15324980601094022

Bainbridge DA (2002) Alternative irrigation systems for arid land restoration. Ecological Restoration 20:2330

Bainbridge DA (2007) A guide for desert and dryland restoration: new hope for arid lands. Island Press, Washington

Bainbridge DA, Fidelibus M, MacAller R (1995) Techniques for plant establishment in arid ecosystems. Restoration and Management Notes 13:198-202

Banker RD, Charnes A, Cooper WW (1984) Some models for estimating technical and scale inefficiencies in data envelopment analysis. Management Science 30:1078-1092

Bean TM, Smith SE, Karpiscak MM (2004) Intensive revegetation in Arizona's Hot Desert The advantages of container stock. Native Plants Journal 5:173-180. doi: 10.2979/NPJ.2004.5.2.173

Becerra PI, Cruz G, Ríos S, Castelli G (2013) Importance of irrigation and plant size in the establishment success of different native species in a degraded ecosystem of central Chile. Bosque (Valdivia) 34:103111

Brouwer C, Prins K, Heibloem M (1989) Irrigation water management: irrigation scheduling. FAO, Rome, Italy

Charnes A, Cooper W, Lewin A, Seiford L (1994) Data envelopment analysis: theory, methodology, and application. Boston: Kluwer Academic Publishers.

Charnes A, Cooper WW, Rhodes E (1978) Measuring the efficiency of decision making units. European Journal of Operational Research 2:429-444

Charnes A, Cooper WW, Rhodes E (1981) Evaluating program and managerial efficiency: an application of data envelopment analysis to program follow through. Management Science 2: 668-697

Coelli TJ, Rao DSP, O'Donnell CJ, Battese GE (2005) An introduction to efficiency and productivity analysis. Springer Science and Business Media

Del Río J, Reque JA, Martínez de Azagra A (2018) To replant or to irrigate: A silvicultural decision model for afforestation projects. Forest Policy and Economics 93:18-29. doi:10.1016/j.forpol.2018.05.007

Dethier JJ, Effenberger A (2012) Agriculture and development: A brief review of the literature. Economic Systems 36:75-205. doi:10.1016/j.ecosys.2011.09.003

Díaz-Balteiro L, Casimiro A, Martinez M, González J (2006) An analysis of productive efficiency and innovation activity using DEA: An application to Spain's wood-based industry. Forest Policy and Economics 8:762-773. doi:10.1016/j.forpol.2005.06.004

Doré T, Makowski D, Malézieux E, Munier-Jolain N, Tchamitchian M, Tittonell P (2011) Facing up to the paradigm of ecological intensification in agronomy: Revisiting methods, concepts and knowledge. European Journal of Agronomy 34:197-210. doi:10.1016/j.eja.2011.02.006

Dyson RG, Allen R, Camanho AS, Podinovski VV, Sarrico CS, Shale EA (2001) Pitfalls and protocols in DEA. European Journal of Operational Research 132:245-259. doi:10.1016/S0377-2217(00)00149-1

Farrell MJ (1957) The Measurement of Productive Efficiency. Journal of the Royal Statistical Society. Series A (General) 120:253-290. doi:10.2307/2343100

Fernández MPM (2005). Metodología de aplicación del Análisis Envolvente de Datos: Evaluación de la eficiencia técnica en la Universidad de Santiago de Compostela. Eduga: Revista Galega do Ensino 737-746

Fernández Y, Flórez R (2006) Aplicación del modelo DEA en la gestión pública. Un análisis de la eficiencia de las capitales de provincia españolas. Revista Iberoamericana de Contabilidad de Gestión 165-202 
Fuentes J, Cruz J (1990) Curso elemental de riego. Madrid, España. Ministerio de Agricultura, Pesca y Alimentación. Servicio de Extensión Agraria.

Golany B, Roll Y (1989) An application procedure for DEA. Omega 17:237-250

Haas DA, Murphy FH (2003) Compensating for non-homogeneity in decision-making units in data envelopment analysis. European Journal of Operational Research 144 530-544. doi:10.1016/S03772217(02)00139-X

Irmak S, Odhiambo LO, Kranz WL, Eisenhauer DE (2011) Irrigation efficiency and uniformity, and crop water use efficiency. Biological Systems Engineering: Papers and Publications 451:1-18

Israelsen OW (1932) Irrigation Principles and Practices, 2ed. John Wiley and Sons Inc, New York

Israelsen OW (1950) Irrigation principles and practices, 1ed. John Wiley and Sons Inc, Chapman and Hall Limited, London

Jensen ME (2007) Beyond irrigation efficiency. Irrigation Science 25:233-245

Jensen R (1982) Adoption and diffusion of an innovation under uncertain profitability. Journal of economic theory 27:182-199

Jurriens M, Zenhun D, Boonstoa J, Feyen J (2001). SURDVE: Surface irrigation, software. Design, Operation, and Evaluation of Basin, Border, and Furrow Irrigation. In: Publication 59 ILRI International Institute for Land Reclamation and Improvementh LRI Wageningen, The Netherlands

Keller AA (1996) Integrated water resource systems: Theory and policy implications. IWMI

Keller AA, Keller J (1995) Effective efficiency: A water use efficiency concept for allocating freshwater resources. Center for Economic Policy Studies, Winrock International Arlington

Liu JS, Lu LY, Lu WM, Lin BJ (2013) A survey of DEA applications. Omega 41:893-902

Mahdhi N, Sghaier M, Smida Z (2014) Efficiency of the irrigation water user association in the Zeuss-Koutine region, south-eastern Tunisia. New Medit 13:47-55

Mahon N, Crute I, Simmons E, Islam MM (2017) Sustainable intensification - "oxymoron" or "third-way"? A systematic review. Ecological Indicators 74:73-97. doi:10.1016/j.ecolind.2016.11.001

Martín R (2007) La Eficiencia Productiva en el Ámbito Universitario: Aspectos Claves para su Evaluación. Estudios de Economía Aplicada 25:793-811

Martínez de Azagra A, Del Río J (2012) Los riegos de apoyo y de socorro en repoblaciones forestales. Foresta 53:32-44

Martínez de Azagra A, Del Río J (2015) Microrriego de brinzales a través de recipientes porosos enterrados: Fundamentos teóricos y prácticos. Cuadernos de la Sociedad Española de Ciencias Forestales 41:4758

Martínez de Azagra A, Del Río J (2017) Oasificación, recolección de agua y riego de brinzales. In: Martínez de Azagra A, Gómez A (eds) Hacia un agua justa Ediciones Universidad de Valladolid, Valladolid, España, pp 285-308

Michael AM (2009) Irrigation: theory and practice. Vikas Publishing House, New Delhi, India

Murias P, De Miguel JC, Rodríguez D (2008) A composite indicator for university quality assesment: The case of Spanish higher education system. Social Indicators Research 89:129-146

Naceur M, Mongi S (2013) The technical efficiency of collective irrigation schemes in south-eastern of Tunisia. International Journal of Sustainable Development and World Policy 2 (6):87-103

Ntantos P, Karpouzos D (2010) Application of data envelopment analysis and performance indicators to irrigation systems in Thessaloniki Plain (Greece). International Journal of Engineering and Natural Sciences 4, 714-720. doi:10.1999/1307-6892/7273 
Olmedo VM, Minjares JL, Camacho E, Hernández ML, Rodríguez JA (2017). Uso del Análisis Envolvente de Datos (DEA) para evaluar la eficiencia de riego en los Módulos del Distrito de Riego No. 041, Río Yaqui (Sonora, México). Revista de la Facultad de Ciencias Agrarias. Universidad Nacional de Cuyo 49:127-148

Pascual B (2008) Riegos de gravedad y a presión. Alfaomega - Universidad Politécnica de Valencia

Pereira H, Marques RC (2017) An analytical review of irrigation efficiency measured using deterministic and stochastic models. Agricultural Water Management 184:28-35. doi:10.1016/j.agwat.2016.12.019

Petersen B, Snapp S (2015) What is sustainable intensification? Views from experts. Land Use Policy 46:110. doi:10.1016/j.landusepol.2015.02.002

Pretty JN (1997) The sustainable intensification of agriculture. Natural Resources Forum 21:247-256

Rey JM (1998) Growth and survival in Quercus ilex L. seedlings after irrigation and artificial shading on Mediterranean set-aside agricultural land. Annals of Forest Science. 55:801-807

Rodríguez J, Camacho E, López R (2004) Application of data envelopment analysis to studies of irrigation efficiency in Andalusia. Journal of Irrigation and Drainage Engineering 130:175-183

Seckler D (1999) Revisiting the IWMI paradigm: Increasing the efficiency and productivity of water use. In. IWMI Water Policy Briefings H024042, International Water Management Institute

Smith A, Snapp S, Chikowo R, Thorne P, Bekunda M, Glover J (2017) Measuring sustainable intensification in smallholder agroecosystems: A review. Global Food Security 12:127-138. doi:10.1016/j.gfs.2016.11.002

Squeo FA, Holmgren M, Jiménez M, Albán L, Reyes J, Gutiérrez JR (2007) Tree establishment along an ENSO experimental gradient in the Atacama Desert. Journal of Vegetation Science 18:195-202

Tang J, Folmer H, Xue J (2015) Technical and allocative efficiency of irrigation water use in the Guanzhong Plain, China. Food Policy 50:43-52. doi:10.1016/j.foodpol.2014.10.008

Tarjuelo J (2005). El riego por aspersión y su tecnología. Mundi-Presa, Madrid, España

Wang XY (2010). Irrigation Water Use Efficiency of Farmers and Its Determinants: Evidence from a Survey in Northwestern China. Agricultural Sciences in China 9:1326-1337. doi:10.1016/S16712927(09)60223-6

Yigezu YA, Ahmed MA, Shideed K, Aw-Hassan A, El-Shater T, Al-Atwan S (2013) Implications of a shift in irrigation technology on resource use efficiency: A Syrian case. Agricultural Systems 118:14-22. doi:10.1016/j.agsy.2013.02.003

Yilmaz B, Harmancioğlu NB (2007) The use of data envelopment analysis in assessment of irrigation efficiency. In: International Congress on River Basin Management, Antalya, Turkey 42:346-357 


\section{Capítulo 5. To replant or to irrigate: A silvicultural decision model for afforestation projects}

This article develops an economic model that compares the option of replacement planting to maintain target density with the option of enhancing seedling survival from the beginning by applying irrigation. The model we develop uses variables common in forestry practice and yields the threshold value of seedling failure at which both alternatives offer the same economic result based on a comparative analysis of costs and benefits. By comparing this threshold with the level of seedling failure expected for an afforestation in the absence of irrigation, the planner can make an informed decision between both alternatives. The model has been applied to thirteen practical cases covering a wide range of plantations with different density, purpose and average annual net income. Based on the results obtained, a k-means clustering is carried out to identify five groups according to their suitability for irrigation. The sensitivity of the model's input variables in respect to the threshold of seedling failure is also analized. Irrigation is profitable when the expected level of seedling failure is high and/or the value of the threshold decision is low. The latter is usually the case at afforestations that require a low acceptable level of seedling failure and/or in productive plantation forestry. 


\section{Introduction}

One of the main causes for the failure of seedlings or plants in afforestation projects developed in arid climates is drought stress (Burdett, 1990; Pinto et al., 2016). The importance and extent of this problem is not fully known, but data speak for themselves: Afforestation projects in arid or semi-arid climates often contemplate, already in their initial designs, a plant mortality rate above 30\% (Chunfeng and Chokkalingam, 2006) or even above 40\% (Çalişkan and Boydak, 2017). Such high mortality rates often require prolonged and expensive failure replantings. In Turkey, seedling replacement was applied to 0.30 of 0.87 million hectares afforested from 2002 to 2012 (Çalişkan and Boydak, 2017) and in Spain, it was applied to 0.86 of 5.09 million hectares afforested from 1946 to 2006 (Vadell et al., 2016). These data serve as illustrative examples of the problem we are going to address. As mentioned, traditionally, seedling failures in the early years after plantation establishment are replaced to ensure the original planting density is maintained. However, this strategy does not always yield adequate results, specifically if the economics of such replacement plantings are considered. Therefore, other complementary measures are taken, such as mulching (Peterson et al., 2009), hydrogels (Crous, 2016), tree shelters (Oliet et al., 2016), water harvesting (Prinz, 2001) and/or irrigation (Bainbridge et al., 1995; Bainbridge, 2007). This paper focuses on the most direct measure: irrigation

\subsection{Seedling irrigation or watering}

Watering to ensure tree establishment is a common and well known practice in forestry and gardening. However, in regard to afforestation it is less common, though interest is slowly increasing because watering reduces or prevents seedling failures due to drought stress in arid zones and critical areas (Baker, 1955; Murphy, 1989; Bainbridge et al., 1995; Ruiz de la Torre et al., 1996; Grantz et al., 1998; Bean et al., 2004; Sánchez et al., 2004; Squeo et al., 2007; Bainbridge, 2007; Alrababah et al., 2008; Martínez de Azagra and Del Río, 2012).

Although conventional irrigation systems (surface, sprinklers or standard drips) may be used, other more specific procedures like subsurface localized irrigation systems are frequently applied because they are highly efficient in saving water: e.g. irrigation with vertical deep pipes stuck into the soil, horizontal drain tubes, irrigation with wicks, irrigation through porous walls or solar distillers (Martínez de Azagra and Del Río, 2012). As the seedlings per hectare to be irrigated are few, the water duty for the establishment of an afforestation is usually lower than $100 \mathrm{~m} 3 \cdot$ ha-1.year-1, compared to 5,000 m3.ha-1'year-1, or more, for irrigated crops. Therefore, we speak of microirrigation or even nano-irrigation.

These types of irrigation differ substantially from those practised in agriculture. They do not seek to maximize production but just the establishment of woody vegetation: trees or shrubs that are well adapted to the site and that -once they have taken root- thrive and develop autonomously without needing permanent watering. For 
that reason, and according to our judgement, in the forestry the term "watering" is more appropriate than "irrigation". It should be also noted that this type of sporadic watering in such low doses does not cause salinization nor modifies the water level in aquifers.

Apart from the fact that water is almost always a scarce resource in drylands, economic aspects are crucial when planning watering for afforestations, as the unit costs of some watering systems may even be higher than the price of the plant to be watered (Del Río et al., 2013). One option is to resort to economic evaluation methods, such as cost-benefit analysis (Hanley and Spash, 1993; Hawkins et al., 2006; Birch et al., 2010), a cost effectiveness analysis (Macmillan et al., 1998; Pywell et al., 2007; Ahtikoski et al., 2010; Wainger et al., 2010), or avoided-cost models (Donovan and Brown, 2008; Snider et al., 2006; Beecher, 1996), in order to choose between the different alternatives and technological options suitable for an afforestation project (Löf et al., 2012; Robbins and Daniels, 2012). The development of decision support models that consider the economic data to be taken into account when planning a plantation poses a big challenge to forestry research (Segura et al., 2014; Nobre et al., 2016). These decision making systems are especially interesting when the available economic resources are scarce (Miller and Hobbs, 2007) and when new afforestation support techniques are applied, e.g. seedling watering systems. 
Table 1. Brief description of some micro-irrigation systems for seedling plantation

\begin{tabular}{|c|c|c|c|}
\hline Irrigation system & Description & Price $(d)$ & Sources \\
\hline Deep pipes & $\begin{array}{l}\text { Short and small vertical plastic tubes (length about } 0.50 \text { to } \\
1.0 \mathrm{~m} \text {; diameter } \approx 0.05 \mathrm{~m} \text { ) or hollow plant stems (Arundo, } \\
\text { Bamboo, etc.) driven into the soil down to root depth. }\end{array}$ & $0.93 € \cdot$ unit $^{-1}$ & (1), (3), (9) \\
\hline Konkom distillers & $\begin{array}{l}\text { Two reused PET bottles with different diameters, } \\
\text { conveniently cut and assembled to form the distiller. }\end{array}$ & $0.86 € \cdot$ unit $^{-1}$ & (5), (9) \\
\hline Porous capsules & $\begin{array}{l}\text { Small and closed receptacles of clay (volume } V \leq 0.5 \mathrm{~L} \text { ) with } \\
\text { one or two entrances, to be connected to an irrigation line. }\end{array}$ & $1.07 € \cdot$ unit $^{-1}$ & (4), (9) \\
\hline Buried clay pots & $\begin{array}{l}\text { Medium to large sized (volume } V \in(1,10) \mathrm{L} \text { ) clay } \\
\text { containers; individual watering. }\end{array}$ & $2.24 € \cdot$ unit $^{-1}$ & (2), (9) \\
\hline Perforated pipes & $\begin{array}{l}\text { Horizontal drain tubes (simple PVC pipelines without } \\
\text { envelope) buried down to root depth (approx. } 0.5 \mathrm{~m} \text { to } 1.0 \\
\mathrm{~m} \text { ). }\end{array}$ & $2.47 € \cdot m^{-1}$ & (1), (9) \\
\hline $\begin{array}{l}\text { Plastic bottles with } \\
\text { wicks }\end{array}$ & $\begin{array}{l}\text { Any reused container connected to a wick. The seedlings are } \\
\text { fed by capillary wicking from a PET bottle. }\end{array}$ & $0.79 € \cdot$ unit $^{-1}$ & (4), (9) \\
\hline $\mathrm{RIES}^{\circ}$ & $\begin{array}{l}\text { Reused PET bottle with two plastic fibre filters inserted at } \\
\text { different heights. }\end{array}$ & $2.90 € \cdot$ unit $^{-1}$ & (6), (9) \\
\hline Ecobag $^{\circ}$ & $\begin{array}{l}\text { Closed container with a shape like a collar pillow, } 20 \mathrm{~L} \\
\text { capacity; delivering water through a felt. }\end{array}$ & $4.11 € \cdot$ unit $^{-1}$ & (7),(9) \\
\hline Waterboxx & $\begin{array}{l}\text { Cylindrical PP bucket with } 15 \mathrm{~L} \text { capacity and a ribbed upper } \\
\text { funnel that collects rainfall (and sometimes, under special } \\
\text { circumstances, horizontal precipitations); water delivery } \\
\text { through a wick. }\end{array}$ & $4.89 € \cdot$ unit $^{-1}$ & (8),(9) \\
\hline
\end{tabular}

Remarks:

Price $(d)$ includes the cost of acquisition, preparation and installation of the watering system at the site to be reforested.

Hourly wage: $5.50 €$ (taxes not included)

The price for the Waterboxx ${ }^{\circ}$ considers a three time use.

- Protected by patent rights

Sources:

(1) Plastic pipe catalogues

(2) Prices of unglazed terracotta

(3) Sánchez et al. (2004)

(4) Bainbridge (2002) and Vargas Rodríguez (2012)

(5) Konkom (Kondenskompressor)

(6) RIES ${ }^{\circ}$ (Reservorios Individuales de Exudación Subterránea)

(7) Eco Bag http://www.ecobagindustries.com.au/

(8) Waterboxx ${ }^{\circ}$ http://www.groasis.com/

(9) Martínez de Azagra and Del Río (2012)

\subsection{Decision support models in silviculture}

There is a long tradition in forestry related to the use of decision models in silviculture, beginning with the classic work of Faustmann in 1849, who determined the most profitable rotation. Faustmann's was the first long term decision model, and it has been followed by many more that we can refer to in numerous works (Kangas and Kangas, 2005; Gilliams et al., 2005; Johnson et al., 2007; Reynolds et al., 2008; Díaz-Balteiro and Romero, 2008; Hanewinkel, 2009; Gardiner and Quine, 2000; Pasalodos-Tato et al., 
2013; Borges et al., 2014; Segura et al., 2014; Bare and Weintraub, 2015; Nobre et al., 2016; Grêt-Regamey et al., 2017). These models have evolved in order to adapt to the new drivers and goals of forestry management (Vacik and Lexer, 2014; Masiero et al., 2015; Nobre et al., 2016). They are helpful when it comes to making silvicultural decisions in the course of the entire production cycle, from pre-commercial thinning to pruning and/or other tending treatments. They seek to optimize production and/or productivity on the treated stands (Martell et al., 1998; Hyytiäinen et al., 2006). These models meet the demands of silviculture along the whole cycle but face a strong uncertainty regarding the future behaviour of economic variables and tree growth, which may be considerably altered by natural hazards (Weintraub and Romero, 2006; Pasalodos-Tato et al., 2013; Rönnqvist et al., 2015; Rinaldi et al., 2015).

These considerations have led other researchers to develop short-term decision support models (Macmillan et al., 1998; Snider et al., 2006; Ahtikoski et al., 2010; Wainger et al., 2010, Donovan and Brown, 2008; Beecher, 1996, among others). They diminish the uncertainty of their predictions while remaining closer in time to the moment of stand establishment (Lexer et al., 2005). They focus on survival and juvenile tree growth arguing that achieving these short-term goals means meeting long-term goals as well. Supporters of the first models consider this view too simplistic (Beecher, 1996; Wainger et al., 2010; Uotila et al., 2010). They warn that this approach can lead to wrong or suboptimal decisions (Pukkala, 1998; Thorsen and Helles, 1998) and handicap economic returns (Eid, 2000; Duvemo and Lämås, 2006; Mechler, 2016).

In order to mitigate this restriction a third group of researchers (Mason et al., 1997; Richardson et al., 2006; Mason and Dzierzon, 2006; Djanibekov and Khamzina, 2016; Pasalodos-Tato et al., 2016, among others) has opted for prolonging the short-term effect of tending treatments by using growth models. This way they can classify the alternatives with the help of long-term economic indicators. This approach integrates the short and long-term visions into decision making related to production, but does not do the same for the establishment of afforestations. The reason is that the most profitable techniques do not guarantee the initial success of seedling establishment. Failings may make necessary extensive and prolonged replanting (Ahtikoski et al., 2010) that will delay the success of an afforestation. The delay might cause a failure to comply with legal, financial, or technical requirements or schedules, or even lead to the failure of the afforestation project itself (Zhou, 1999; Löf et al., 2012).

The decision model we develop in this paper makes feasible both a short-term and a long-term approach. It focuses on a specific problem that affects the initial success of plant establishment: preventing seedling failure in afforestations due to drought stress by using watering as tending treatment.

The paper's main goal is to develop and validate a decision model based on economics that helps to choose the best of the following two solutions: replacement planting or seedling watering. As additional goals we have considered: i) applying the model to different types of afforestation projects to find out in which cases watering is 
more competitive than replacement planting, ii) evaluating the uncertainty and sensitivity of the model's input variables.

\section{Materials and Methods}

\subsection{Description of the MThreshold Model}

The model compares two alternatives (watering or replacement planting) and yields the threshold value $(M)$ that equals them from an economic point of view (eq. 1).

The cost-benefit analysis of both alternatives under study requires:

a) A specification of the cost-benefit equations for each option, considering only those elements that differ: watering costs (first element), plant replacement costs (second element), and the difference between the expected benefits (third element), (eqs. 2 to 4 , respectively).

b) Discounting the economic value of each option at the end of each term to its present value using an annual interest rate ( $i=$ constant).

c) Establishing a replacement planting strategy for the second alternative (eq. 5). The usual procedure is replacing dead plants with new seedlings, which are placed next to the failure. This practice is repeated annually, until a plant density is achieved that meets the acceptable level of seedling failures $(A L F)$.

For a given plantation density $\rho$ and a failure level $M$ referring only to the first year that seedlings grow under open field conditions, the failed seedlings that have to be replaced each year $j$ follow a geometric progression with common ratio $M\left(\rho \cdot M^{j-1}\right)$. When the year's failed seedlings are less or equal to the required tolerance $\left(M^{j-1} \leq A L F\right)$, replacement is stopped. Equation 5 shows this replanting strategy as referred to the last year in which failed seedlings would have to be replaced (year $j=N$ ).

Once the value of $M$ has been obtained (in per unit, $0.0 \leq M \leq 1.0$ ), an informed decision can be made: if the expected level of seedling failure for a given afforestation $\left(M_{R}\right)$ surpasses the threshold $M$, watering will be a better option than failure replanting. In the opposite case, we recommend resorting to the traditional technique of replacing failed seedlings.

Decision rule: $\left\{\begin{aligned} & \text { if } M_{R} \geq M \rightarrow \text { Watering } \\ \text { if } M_{R}<M & \rightarrow \text { Replacement planting }\end{aligned}\right.$

Figure 1 shows this decision rule combined with the model in a flow diagram. 


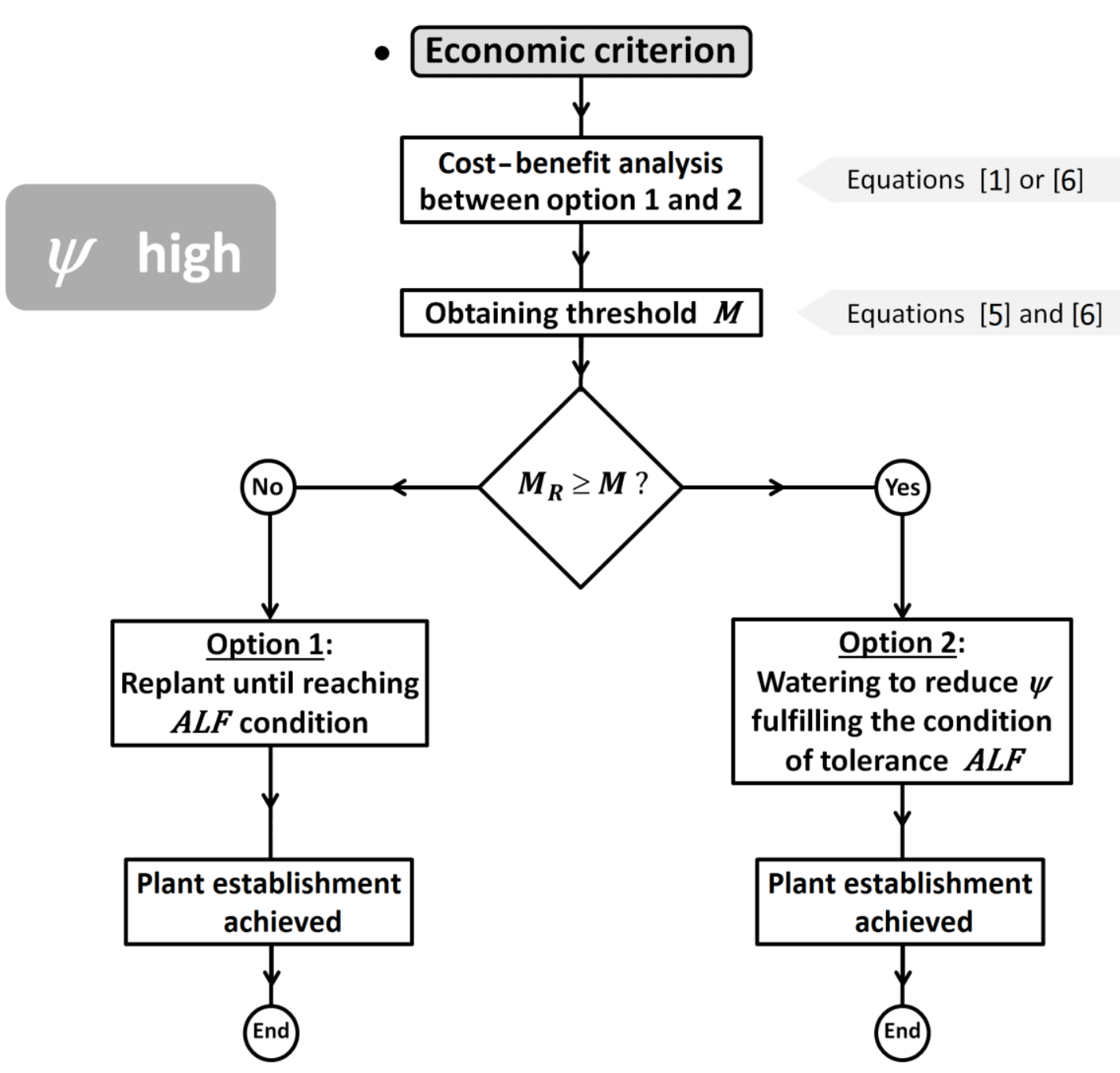

Figure 1. Flowchart of the economic decision model based on variable $M$

Note: For tending treatments other than irrigation the procedure is quite similar to that proposed in this paper. The only difference lies in the cost-benefit equations, which have to be specified for each case. The meaning of the acronyms in Table 2.

The five equations of the model are:

Cost-benefit comparison of both alternatives: $C_{\text {wat }} \leq C_{\text {rep }}+\Delta B$

Watering costs: $C_{w a t}=h \cdot d \cdot \rho+\rho \cdot \sum_{j=1}^{j=n_{r i}} \frac{w_{j} \cdot N R_{j}}{(1+i)^{j-1}}$

Plant replacement costs: $C_{r e p}=\rho \cdot \sum_{j=2}^{j=N} \frac{c_{j} \cdot M^{j-1}}{(1+i)^{j-1}}+\sum_{j=2}^{j=N} \frac{a_{j}+b_{j} \cdot \rho \cdot M^{j-1}}{(1+i)^{j-1}}$

Difference between the expected benefits for each option:

$\Delta B=B I_{P V}+L P_{P V}=R \cdot\left[\sum_{j=e-\epsilon}^{j=e-1} \frac{1}{(1+i)^{j-1}}+\sum_{j=e}^{j=e+N-2} \frac{M^{j-e+1}}{(1+i)^{j-1}}\right]$

Replacement planting strategy: $N \geq \frac{\ln A L F}{\ln M}$

Table 2 includes all symbols and their meaning. The terms of the cost and benefit equations are explained in detail in Appendix A. 
Table 2. Notation

\begin{tabular}{|c|c|}
\hline Symbol & Meaning \\
\hline$a, a_{j}$ & Constant term of the linear equation to determine $\mathrm{Cm}$ in year $j\left\{\epsilon \cdot \mathrm{ha}^{-1}\right\}$ \\
\hline$A L F$ & Acceptable level of seedling failure $\{$ in per unit $\}$ \\
\hline$b, b_{j}$ & Slope of the line used to determine $\mathrm{Cm}$ in year $j\left\{€ \cdot\right.$ plant $\left.^{-1}\right\}$ \\
\hline$B I_{j}, B I_{P V}$ & Early gains in year $j$, Early gains due to the use of irrigation updated to current value $\left\{€ \cdot h a^{-1}\right\}$ \\
\hline$c, c_{j}$ & Unit price of the seedlings $\left\{€ \cdot\right.$ unit $\left.^{-1}\right\}$ \\
\hline C & Initial afforestation costs (when equal for both considered alternatives) $\left\{€\right.$ ha $\left.^{-1}\right\}$ \\
\hline$C_{m}$ & Costs of the replanting works (soil and site preparation, etc.) $\left\{€ \cdot\right.$ ha $\left.^{-1}\right\}: C m_{j}=a_{j}+b_{j} \cdot \rho \cdot M^{j-1}$ \\
\hline$C_{\text {rep }}$ & Total replanting costs for failed seedlings $\left\{€ \cdot h a^{-1}\right\}$ \\
\hline$C_{\text {wat }}$ & Total irrigation costs $\left\{€ \cdot \mathrm{ha}^{-1}\right\}$ \\
\hline$d$ & Average price per unit of an irrigation system (including installation costs) $\left\{€ \cdot\right.$ plant $\left.^{-1}\right\}$ \\
\hline$e$ & Year in which the plantation begins to be productive without irrigation \{year\} \\
\hline$h$ & $\begin{array}{l}\text { Difficulty (hardness degree) related to installing an irrigation system. Normally: } h \in(0.75,1.5) \\
\text { \{unitless\} }\end{array}$ \\
\hline$i$ & Discount rate $\{$ in per unit $\}$ \\
\hline j & Subscript denoting the order number of a year ( $j=1$ is the year of afforestation) \{unitless $\}$ \\
\hline$L P_{j}, L P_{P V}$ & $\begin{array}{l}\text { Lost profit in year } j \text { (due to a delay in the obtention of benefits ), Lost profit updated to current value } \\
\left\{€ \cdot h a^{-1}\right\}\end{array}$ \\
\hline M & $\begin{array}{l}\text { Threshold of seedling failure (for which the costs of the two considered alternatives match: } \\
\text { with/without irrigating) \{in per unit\}: } 0.0 \leq M \leq 1.0\end{array}$ \\
\hline$M_{R}$ & Expected level of seedling failure (without irrigation) \{in per unit\} (mean value) \\
\hline$n_{r i}$ & Number of years during which the seedlings are irrigated $\left\{\right.$ unitless\}: $n_{r i} \geq 1$ \\
\hline$N$ & Last year of beating up (i.e. replanting dead seedlings) \{unitless\}: $N \geq 1$ \\
\hline$N R, N R_{j}$ & Annual amount of water supplied to each seedling by irrigation $\left\{L \cdot\right.$ plant $^{-1} \cdot$ year $\left.^{-1}\right\}$, (in year $j$ ) \\
\hline PV & Subscript denoting cost discounted to present value \{unitless\} \\
\hline$R$ & Average annual net income $\left\{€ /\right.$ ha\}of a forest at age $e$ (including direct and indirect benefits) $\left\{€ \cdot h^{-1}\right\}$ \\
\hline$w, w_{j}$ & $\begin{array}{l}\text { Irrigating costs per unit (depending on water application expenses and on the price of the water) }\{€ \cdot L- \\
\left.{ }^{1}\right\},(\text { in year } j \text { ) }\end{array}$ \\
\hline$\Delta B$ & $\begin{array}{l}\text { Difference between the benefit resulting from irrigating and the benefit when replacing failed } \\
\text { seedlings }\left\{€ \cdot h \mathrm{a}^{-1}\right\}\end{array}$ \\
\hline$\varepsilon$ & Number of years by which production is accelerated due to irrigation \{unitless\} $\varepsilon \ll e$ \\
\hline$\mu$ & $\begin{array}{l}\text { Level of seedling failure due to causes other than water stress: deficient site preparation works; } \\
\text { abiotic damages; herbivory; etc. \{in per unit\} (mean value) }\end{array}$ \\
\hline$\rho$ & Initial plantation density \{number of seedlings per hectare; or number of seeding points per hectare\} \\
\hline$\psi$ & Level of seedling failure due to water stress $\{$ in per unit $\}$ (mean value): $M_{R}=\psi+\mu[7]$ \\
\hline$€$ & Euro, official currency of the eurozone \\
\hline
\end{tabular}

Equations (2, 3 y 4$)$ are replaced in (eq. 1), resulting in the following inequality:

$h \cdot d \cdot \rho+\rho \cdot \sum_{j=1}^{j=n_{r i}} \frac{w_{j} \cdot N R_{j}}{(1+i)^{j-1}} \leq \rho \cdot \sum_{j=2}^{j=N} \frac{c_{j} \cdot M^{j-1}}{(1+i)^{j-1}}+\sum_{j=2}^{j=N} \frac{a_{j}+b_{j} \cdot \rho \cdot M^{j-1}}{(1+i)^{j-1}}+R \cdot \sum_{j=e-\epsilon}^{j=e-1} \frac{1}{(1+i)^{j-1}}+R \cdot \sum_{j=e}^{j=e+N-2} \frac{M^{j-e+1}}{(1+i)^{j-1}}$ (6)

Together with (5), this inequality (6) forms a system of diophantine inequations with two unknown variables $(M$ and $N)$. The pair of values $(M, N)$, that satisfies both 
expressions defines the solution of the problem. The main output variable of the model is the threshold value $\mathrm{M}$. The second variable $(\mathrm{N})$ may also influence the decision. The value of $\mathrm{N}$ becomes interesting when we have information about how many times it is necessary to replace the failed seedlings on the studied area in order to have a plantation with the desired target density.

\subsection{Calculation assumptions}

The model starts from the assumptions shown in Table 3. The first four have general validity (i.e., they are inherent to cost-benefit analysis and to seedling planting projects), while the other six are more specific (i.e., they adjust to the most common afforestation conditions, but can be ignored or modified in order to adapt them to a particular situation).

Table 3. Assumptions of the MThreshold Model

\begin{tabular}{|c|c|}
\hline Number & General assumptions \\
\hline 1 & $\begin{array}{l}\text { Failure replanting and irrigation are perfect substitute goods; the investor is risk neutral. } \\
\text { Marginal rate of substitution equal to one. }\end{array}$ \\
\hline 2 & $\begin{array}{l}\text { From an economic point of view, the initial plantation density fixed by the project engineer } \\
(\rho) \text { is appropriate as it takes into account both the direct and the indirect benefits of the future } \\
\text { forest. }\end{array}$ \\
\hline 3 & $\begin{array}{l}\text { With regard to the final density of the afforestation, a certain failure tolerance }(A L F) \text { is } \\
\text { accepted. This does not affect the established economic objective. }\end{array}$ \\
\hline \multirow[t]{2}{*}{4} & $\begin{array}{l}\text { The value of the expected total seedling failure }\left(M_{R}\right) \text { for an afforestation site is known or can } \\
\text { be estimated. }\end{array}$ \\
\hline & Specific assumptions \\
\hline 5 & The initial afforestation costs $(C)$ are the same with and without irrigation. \\
\hline 6 & $\begin{array}{l}\text { The failure replanting strategy consists in replacing all failures during the first }(N-1) \text { years with } \\
\text { new and equivalent seedlings, until the final density fulfills the required tolerance }(A L F) \text {. }\end{array}$ \\
\hline 7 & $\begin{array}{l}\text { The target woodland produces a constant annual net income }(R) \text { from a certain year }(e) \\
\text { onwards. This date can be brought forward or backward depending on the chosen option of } \\
\text { afforestation. }\end{array}$ \\
\hline 8 & $\begin{array}{l}\text { Seedling failure due to causes other than water stress (herbivory, competition or others) is } \\
\text { lower than the established tolerance }(A L F) \text {. }\end{array}$ \\
\hline 9 & When using irrigation, seedling failure due to water stress will not occur. \\
\hline 10 & $\begin{array}{l}\text { Significant numbers of failures will only occur during the seedlings' first year in the afforested } \\
\text { area, being water stress its most common cause. }\end{array}$ \\
\hline
\end{tabular}

\subsection{Case studies}

We apply the model to thirteen illustrative dryland afforestation projects that cover an ample range of different types of plantation, selected by the authors based on Ingles et al. (2002), FAO (2005), Batra and Pirard (2015) and our own experience. Each case study is defined by a specific purpose, a forest site quality, a slope gradient, species selection, soil preparation and an expected future income (Table 4). Other more numerical attributes to describe each case are: initial afforestation cost $(C)$, planting 
density $(\rho)$, acceptable level of seedling failure $(A L F)$, average annual net income $(R)$ from a certain year onwards $(e)$, and watering costs $\left(C_{w a t}\right)$.

Table 4. Considered case studies

\begin{tabular}{|c|c|c|c|c|c|c|c|c|}
\hline Number & Case & Purpose & $\begin{array}{l}\text { Forest } \\
\text { site }\end{array}$ & $\begin{array}{l}\text { Slope } \\
\text { gradient }\end{array}$ & Species & $\begin{array}{l}\text { Soil } \\
\text { preparation }\end{array}$ & Income Aspects & Source \\
\hline 1 & $\begin{array}{l}\text { Commercial } \\
\text { timber } \\
\text { plantation }\end{array}$ & $\begin{array}{l}\text { Production of } \\
\text { commercial } \\
\text { timber }\end{array}$ & $\begin{array}{l}\text { Premium } \\
\text { quality }\end{array}$ & $\begin{array}{l}\text { Less } \\
\text { than } \\
10 \%\end{array}$ & $\begin{array}{l}\text { Commercial timber } \\
\text { species (Juglans spp.) }\end{array}$ & $\begin{array}{l}\text { Ploughing or } \\
\text { ripping }\end{array}$ & $\begin{array}{l}\text { Estimated mean } \\
\text { production: } 13 \\
\mathrm{~m}^{3} \cdot \mathrm{ha}^{-1} \text { and selling } \\
\text { price is } 500 € \cdot \mathrm{m}^{-3}\end{array}$ & $\begin{array}{l}\text { Muncharaz } \\
\text { 2012; Molina } \\
\text { et al. } 2014\end{array}$ \\
\hline 2 & $\begin{array}{l}\text { Habitat } \\
\text { restoration } \\
\text { plantation }\end{array}$ & $\begin{array}{l}\text { To increase the } \\
\text { available forest } \\
\text { habitat and } \\
\text { improve its } \\
\text { connectivity with } \\
\text { the landscape }\end{array}$ & $\begin{array}{l}\text { Low } \\
\text { quality }\end{array}$ & $\begin{array}{l}\text { Less } \\
\text { than } \\
30 \%\end{array}$ & Conifer or oak & $\begin{array}{l}\text { Contour } \\
\text { ripping }\end{array}$ & $\begin{array}{l}\text { Only the received } \\
\text { income } \\
\text { fraction has been } \\
\text { considered and the } \\
\text { indirect benefits } \\
\text { have not been } \\
\text { taken into account }\end{array}$ & $\begin{array}{l}\text { Consejería } \\
\text { de Medio } \\
\text { Ambiente } \\
2005\end{array}$ \\
\hline 3 & $\begin{array}{l}\text { Multifunctional } \\
\text { plantation }\end{array}$ & Multifunctional & $\begin{array}{l}\text { Low } \\
\text { quality }\end{array}$ & $\begin{array}{l}10 \text { to } \\
30 \%\end{array}$ & $\begin{array}{l}\text { Mixed } \\
\text { conifer/broadleaved }\end{array}$ & $\begin{array}{l}\text { Ripping or } \\
\text { ploughing }\end{array}$ & $\begin{array}{l}\text { The annual net } \\
\text { income }(R) \text { is } \\
\text { comparable to the } \\
\text { mean direct } \\
\text { (productive) plus } \\
\text { indirect } \\
\text { (environmental } \\
\text { and recreational) } \\
\text { benefits for } \\
\text { established for forests } \\
\text { Spanish }\end{array}$ & $\begin{array}{l}\text { Ministerio } \\
\text { de Medio } \\
\text { Ambiente y } \\
\text { Medio Rural } \\
\text { y Marino } \\
2011 \text { M }\end{array}$ \\
\hline 4 & $\begin{array}{l}\text { Afforestation of } \\
\text { agricultural land }\end{array}$ & $\begin{array}{l}\text { Marginal parcel } \\
\text { for agriculture }\end{array}$ & $\begin{array}{l}\text { Low } \\
\text { quality }\end{array}$ & Flat & $\begin{array}{l}\text { Mixed } \\
\text { conifer/broadleaved }\end{array}$ & Ripping a flat & $\begin{array}{l}\text { Mean direct } \\
\text { (productive) plus } \\
\text { indirect } \\
\text { (environmental } \\
\text { and recreational) } \\
\text { benefits }\end{array}$ & $\begin{array}{l}\text { Ministerio } \\
\text { de Medio } \\
\text { Ambiente y } \\
\text { Medio Rural } \\
\text { y Marino } \\
2011\end{array}$ \\
\hline 5 & Fruticulture & $\begin{array}{l}\text { Production of } \\
\text { almonds }\end{array}$ & $\begin{array}{l}\text { Premium } \\
\text { quality }\end{array}$ & $\begin{array}{l}\text { Less } \\
\text { than } \\
10 \%\end{array}$ & Almond tree & $\begin{array}{l}\text { Full } \\
\text { ploughing }\end{array}$ & $\begin{array}{l}\text { Estimated } \\
\text { production: } 1000 \\
\mathrm{~kg} \cdot \mathrm{ha}^{-1} \text { year }^{-1} \text { of } \\
\text { almonds with shell }^{2}\end{array}$ & $\begin{array}{l}\text { Socias and } \\
\text { Couceiro } \\
2014\end{array}$ \\
\hline 6 & $\begin{array}{l}\text { Truffle } \\
\text { cultivation }\end{array}$ & $\begin{array}{l}\text { Production of } \\
\text { Tuber nigrum }\end{array}$ & $\begin{array}{l}\text { Premium } \\
\text { quality }\end{array}$ & $\begin{array}{l}\text { Less } \\
\text { than } \\
10 \%\end{array}$ & $\begin{array}{ll}\text { Broadleaved } & \text { trees } \\
\text { (Quercus } & \text { spp.) } \\
\text { mycorrhized } & \text { with } \\
\text { Tuber nigrum } & \end{array}$ & $\begin{array}{l}\text { Ripping or } \\
\text { ploughing }\end{array}$ & $\begin{array}{l}\text { Production: } 20 \\
\mathrm{~kg} \cdot \mathrm{ha}^{-1} \cdot \text { year }^{-1} \text {. The } \\
\text { considered } \\
\text { producer price is } \\
300 € \cdot \mathrm{kg}^{-1}\end{array}$ & $\begin{array}{l}\text { Morcillo et } \\
\text { al. } 2015\end{array}$ \\
\hline 7 & $\begin{array}{l}\text { Non-wood } \\
\text { forestry goods } \\
\text { (fungi) }\end{array}$ & Marketable fungi & $\begin{array}{l}\text { Medium } \\
\text { quality }\end{array}$ & $\begin{array}{l}\text { Less } \\
\text { than } \\
10 \%\end{array}$ & $\begin{array}{l}\text { Inoculated seedlings } \\
\text { with edible fungi } \\
\text { (Boletus spp. and/or } \\
\text { others) }\end{array}$ & $\begin{array}{l}\text { Ploughing or } \\
\text { ripping }\end{array}$ & $\begin{array}{l}\text { The estimated } \\
\text { production of } \\
\text { marketable fungi is } \\
30 \quad \mathrm{~kg} \cdot \mathrm{ha}^{-1} \cdot \mathrm{year}^{-1} \\
\text { and the estimated } \\
\text { selling price } 12 \\
€ \cdot \mathrm{kg}^{-1}\end{array}$ & $\begin{array}{l}\text { Martínez- } \\
\text { Peña et al. } \\
\text { 2011; } \\
\text { Ministerio } \\
\text { de Medio } \\
\text { Ambiente y } \\
\text { Medio Rural } \\
\text { y Marino } \\
\text { 2011; Díaz- } \\
\text { Balteiro et } \\
\text { al. } 2013 \text { ? }\end{array}$ \\
\hline 8 & $\begin{array}{l}\text { Extensive } \\
\text { xeriscaping }\end{array}$ & $\begin{array}{l}\text { Woodland for } \\
\text { recreational use } \\
\text { on terrain with a } \\
\text { high visual } \\
\text { exposure }\end{array}$ & $\begin{array}{l}\text { Low } \\
\text { quality }\end{array}$ & $\begin{array}{l}\text { Steep } \\
\text { slopes } \\
>30 \%\end{array}$ & $\begin{array}{l}\text { Mixed conifer and } \\
\text { broadleaved } \\
\text { plantation }\end{array}$ & $\begin{array}{l}\text { Bench } \\
\text { terraces built } \\
\text { with a } \\
\text { walking } \\
\text { excavator }\end{array}$ & Recreational value & $\begin{array}{l}\text { Ministerio } \\
\text { de Medio } \\
\text { Ambiente y } \\
\text { Medio Rural } \\
\text { y Marino } \\
2011\end{array}$ \\
\hline
\end{tabular}




\begin{tabular}{|c|c|c|c|c|c|c|c|c|}
\hline Number & Case & Purpose & $\begin{array}{l}\text { Forest } \\
\text { site }\end{array}$ & $\begin{array}{l}\text { Slope } \\
\text { gradient }\end{array}$ & Species & Soil preparation & Income Aspects & Source \\
\hline 9 & $\begin{array}{l}\text { Plantation in a } \\
\text { critical area }\end{array}$ & $\begin{array}{l}\text { Critical areas } \\
\text { where } \\
\text { afforestation using } \\
\text { classical } \\
\text { techniques fails } \\
\text { due to water stress }\end{array}$ & $\begin{array}{l}\text { Low } \\
\text { quality }\end{array}$ & $\begin{array}{l}\text { Steep } \\
\text { slopes } \\
>30 \%\end{array}$ & $\begin{array}{l}\text { Conifer } \\
\text { plantations } \\
\text { (native pines) }\end{array}$ & $\begin{array}{l}\text { Bench } \\
\text { terraces built } \\
\text { with a walking } \\
\text { excavator }\end{array}$ & $\begin{array}{l}\text { Mean indirect } \\
\text { benefits }\end{array}$ & $\begin{array}{l}\text { Ruiz de la } \\
\text { Torre et al. } \\
1996 ; \\
\text { Ministerio } \\
\text { de Medio } \\
\text { Ambiente y } \\
\text { Medio Rural } \\
\text { y Marino } \\
2011 \\
\end{array}$ \\
\hline 10 & Windbreak & $\begin{array}{l}\text { Protection in all } \\
\text { directions of } \\
\text { herbaceous crops } \\
\text { that are sensitive } \\
\text { to wind }\end{array}$ & $\begin{array}{l}\text { Medium } \\
\text { quality }\end{array}$ & $\begin{array}{l}\text { Less than } \\
10 \%\end{array}$ & $\begin{array}{l}\text { Mixed } \\
\text { windbreak } \\
\text { screen of } \\
\text { conifers and } \\
\text { broadleaved } \\
\text { seedlings }\end{array}$ & $\begin{array}{l}\text { Ripping a flat } \\
\text { parcel }\end{array}$ & $\begin{array}{l}\text { Avoided loss of } \\
\text { crops }\end{array}$ & $\begin{array}{l}\text { Peri and } \\
\text { Pastur 1998; } \\
\text { Peri and } \\
\text { Bloomberg } \\
2002\end{array}$ \\
\hline 11 & $\begin{array}{l}\text { Protection of } \\
\text { hydraulic } \\
\text { infrastructures }\end{array}$ & $\begin{array}{l}\text { Forest and } \\
\text { hydrologic } \\
\text { restoration works } \\
\text { on the headwaters } \\
\text { of a watershed to } \\
\text { protect a reservoir }\end{array}$ & $\begin{array}{l}\text { Low } \\
\text { quality }\end{array}$ & $\begin{array}{l}\text { Difficult to } \\
\text { access, } \\
\text { high } \\
\text { gradient } \\
\text { terrain } \\
>50 \%\end{array}$ & Conifer & $\begin{array}{l}\text { Digging holes } \\
\text { with a walking } \\
\text { excavator on } \\
\text { impoverished }\end{array}$ & Avoided loss & $\begin{array}{l}\text { Catalina and } \\
\text { Vicente } \\
2001 ; \\
\text { Ministerio } \\
\text { de Medio } \\
\text { Ambiente y } \\
\text { Medio Rural } \\
\text { y Marino } \\
2011 \\
\end{array}$ \\
\hline 12 & $\begin{array}{l}\text { Protection of } \\
\text { road } \\
\text { infrastructures }\end{array}$ & $\begin{array}{ll}\text { Sustainment } & \text { and } \\
\text { stabilization of a } \\
\text { highway bank } \\
\text { slope }\end{array}$ & $\begin{array}{l}\text { Low } \\
\text { quality }\end{array}$ & $\begin{array}{l}\text { Steep } \\
\text { slopes } \\
>30 \%\end{array}$ & Conifer & $\begin{array}{l}\text { Preliminary } \\
\text { brushing out and } \\
\text { soil treatment by } \\
\text { manual hole } \\
\text { digging }\end{array}$ & $\begin{array}{l}\text { Avoided cost of a } \\
\text { one-hour traffic } \\
\text { interruption } \\
\text { caused by an } \\
\text { unstable highway } \\
\text { bank slope. } \\
\text { Calculations based } \\
\text { on a highway with } \\
\text { a mean traffic } \\
\text { intensity of } 1000 \\
\text { vehicles } \cdot \mathrm{h}^{-1} \text { and a } \\
\text { trip cost of } 4.7 € \cdot \mathrm{h}^{-} \\
1\end{array}$ & $\begin{array}{l}\text { García Viñas } \\
\text { et al. 1993; } \\
\text { Salado and } \\
\text { Astals 2010; } \\
\text { Ministerio } \\
\text { de Fomento } \\
2014\end{array}$ \\
\hline 13 & $\begin{array}{l}\text { Protection of } \\
\text { rail } \\
\text { infrastructures }\end{array}$ & $\begin{array}{l}\text { Sustainment and } \\
\text { stabilization of a } \\
\text { railway bank slope }\end{array}$ & $\begin{array}{l}\text { Low } \\
\text { quality }\end{array}$ & $\begin{array}{l}\text { Steep } \\
\text { slopes } \\
>30 \%\end{array}$ & Conifer & $\begin{array}{l}\text { Manual } \\
\text { digging }\end{array}$ & $\begin{array}{l}\text { Avoided cost of the } \\
\text { refunding of a rail } \\
\text { ticket as a } \\
\text { compensation for a } \\
\text { delay caused by } \\
\text { the blockage of the } \\
\text { rails due to an } \\
\text { unstable railway } \\
\text { bank slope. } \\
\text { Calculations based } \\
\text { on a train with a } \\
\text { capacity of } 400 \\
\text { passengers, a } 60 \% \\
\text { occupancy rate } \\
\text { and an average } \\
\text { ticket price of } 60 €\end{array}$ & $\begin{array}{l}\text { García Viñas } \\
\text { et al. 1993; } \\
\text { Salado and } \\
\text { Astals 2010; } \\
\text { Fernández } \\
\text { and Vázquez } \\
2012\end{array}$ \\
\hline
\end{tabular}

Note: These case studies are established to obtain a wide vision about plantations for the model MThreshold. They should not be interpreted as precise or local afforestation methods.

For each case study, values suitable in Spanish forestry for the entry parameters have been used (columns 3 to 10 of Table 5). The meaning of these parameters is described in detail in Appendix A and in Table 2. For all cases, the same watering system has been considered: manual watering through a vertical deep pipe stuck into the soil next to each seedling; a commercial polyethylene pipe (PE) with $32 \mathrm{~mm}$ diameter and a 
length of $500 \mathrm{~mm}$; watering during the first year as follows: $d=0.93 € \cdot$ plant $^{-1} ; w=0.005$ $€ \cdot \mathrm{L}^{-1} ; N R=6.4 \mathrm{~L} \cdot$ plant $^{-1}$ year ${ }^{-1}$; and $n_{r i}=1$ year (Sánchez et al., 2004; Del Río et al., 2013, 2016). In order to shorten our presentation and for all cases, we consider that, due to watering, the average annual net income $(R)$ will start two years earlier ( $\varepsilon=2$ years). The interest rate has been established at $4 \%$, which is a common rate applied to the public funding of dryland restoration projects in EU (European Comission and European Investment Bank, 2016), and at 10\% for developing countries and REDD projects (Graham et al., 2016). The acceptable level of seedling failure has been set in accordance with the technical specifications defined for each plantation project. When resolving the system of equations (5 and 6), we obtain the values of $M$ and $N$ for each case study (last two columns of Table 5).

Table 5. Input data and results of the model for the considered plantation designs

\begin{tabular}{|c|c|c|c|c|c|c|c|c|c|c|c|c|}
\hline Case & Number & $a$ & $\boldsymbol{b}$ & c & $\rho$ & $A L F$ & $R$ & $e$ & $i$ & C & $M$ & $N$ \\
\hline $\begin{array}{l}\text { Commercial timber } \\
\text { plantation }\end{array}$ & 1 & 60 & 0.53 & 0.49 & 1600 & 0.3 & 2500 & 41 & 0.04 & 1692 & $0.300 *$ & 1 \\
\hline $\begin{array}{l}\text { Habitat restoration } \\
\text { plantation }\end{array}$ & 2 & 60 & 0.53 & 0.3 & 800 & 0.3 & 60 & 61 & 0.04 & 724 & 0.625 & 3 \\
\hline $\begin{array}{l}\text { Multifunctional } \\
\text { plantation }\end{array}$ & 3 & 80 & 1.3 & 0.3 & 1100 & 0.3 & 287 & 21 & 0.04 & 1840 & 0.386 & 2 \\
\hline $\begin{array}{l}\text { Afforestation of } \\
\text { agricultural land }\end{array}$ & 4 & 60 & 0.53 & 0.41 & 800 & 0.3 & 287 & 21 & 0.04 & 812 & 0.508 & 2 \\
\hline Fruticulture & 5 & 60 & 0.53 & 1 & 2315 & 0.03 & 5000 & 11 & 0.04 & 3602 & $0.030 *$ & 1 \\
\hline Truffle cultivation & 6 & 60 & 0.53 & 6 & 400 & 0.03 & 5000 & 21 & 0.1 & 2672 & $0.030 *$ & 1 \\
\hline $\begin{array}{l}\text { Non-wood forestry } \\
\text { goods (fungi) }\end{array}$ & 7 & 80 & 1.3 & 0.62 & 1600 & 0.03 & 650 & 21 & 0.04 & 3152 & 0.196 & 3 \\
\hline Extensive xeriscaping & 8 & 80 & 1.3 & 0.62 & 1100 & 0.03 & 1500 & 41 & 0.04 & 2192 & 0.137 & 2 \\
\hline $\begin{array}{l}\text { Plantation in a critical } \\
\text { area }\end{array}$ & 9 & 90 & 1.75 & 0.3 & 800 & 0.3 & 135 & 21 & 0.04 & 1730 & 0.337 & 2 \\
\hline Windbreak screen & 10 & 20 & 0.63 & 1 & 2500 & 0.03 & 1100 & 21 & 0.04 & 4095 & 0.240 & 3 \\
\hline $\begin{array}{l}\text { Protection of hydraulic } \\
\text { infrastructures }\end{array}$ & 11 & 90 & 1.75 & 0.3 & 1600 & 0.03 & 2823 & 21 & 0.04 & 3370 & $0.030 *$ & 1 \\
\hline $\begin{array}{l}\text { Protection of road } \\
\text { infrastructures }\end{array}$ & 12 & 90 & 1.75 & 0.3 & 400 & 0.03 & 4700 & 5 & 0.1 & 910 & $0.030 *$ & 1 \\
\hline $\begin{array}{l}\text { Protection of rail } \\
\text { infrastructures }\end{array}$ & 13 & 90 & 1.75 & 0.62 & 400 & 0.03 & 12000 & 5 & 0.1 & 1038 & $0.030 *$ & 1 \\
\hline
\end{tabular}

Data sources: $a, b, c, \rho, A L F, R, e$ : Values based on the references shown on table 1 and table 4.

Monetary unit: euro $(€)$

$h=1.0$

$C=a+(b+c) \cdot \rho$

$(*)$ The inferior limit of $M$ is $A L F$, a situation in which failure replacement is not necessary; $N=1$.

Next, we have grouped the studied cases according to their suitability for watering. The unsupervised learning algorithm used is k-means clustering with running means based on the values of $M$ and $A L F$. The number of groups has been established 
by elbow rule (Tibshirani et al., 2001). Calculations have been done with SPSS software (IBM Corp. Released 2011. IBM SPSS Statistics for Windows, Version 20.0. Armonk, NY: IBM Corp.).

\subsection{Sensitivity analysis procedure}

For a better use of the model it is advisable to identify the input variables that most influence on the main output variable $(M)$, and to analyze the effect on $M$ of possible uncertainties of these input variables, by means of a global sensitivity analysis (Sobol', 2001; Saltelli, 2002; Saltelli et al., 2010). Calculations are made using the software SimLab (Joint Research Centre of the European Commission. Released 2008. SimLab, Version 2.2.).

In this paper, we rely on the thirteen case studies we have analyzed to establish the variable's range, i.e., the variation interval for each variable. These intervals, or individual values, are shown in Table 6. Table 1 offers data to determine the range of variable $d$ (the unit cost of different watering systems). The number of years during which it is advisable to apply additional watering to the seedling until it is established $\left(n_{r i}\right)$ are usually few; therefore, the corresponding interval is $n_{r i} \leq 5$. In fact, in most cases it is sufficient to water the plants only during the first year $\left(n_{r i}=1\right)$, except in those environments where the natural regeneration of species usually fails for several consecutive years (semiarid climates or critical areas). The price of the watering water $(w)$ varies considerably from one site to another, but the range considered covers almost all possible situations $\left(0 \leq w \leq 0.1 € \cdot \mathrm{L}^{-1}\right)$. An ample interval has also been used for the individual annual water supply $\left(5 \leq N R \leq 100 \mathrm{~L}\right.$ plant $^{-1} \cdot$ year $\left.^{-1}\right)$.

\section{Results}

The first and main result of this paper is the decision support model MThreshold itself. By means of a system of two inequations [eqs. 5 and 6] with two unknowns, (variables $M$ and $N$ ) the model answers the question of when it is profitable, from an economic point of view, to irrigate seedlings in order to avoid failures, instead of not irrigate them and carrying out replacement planting during a number of years to maintain the target density.

\subsection{Model application results}

The model has been applied to thirteen case studies; results are shown in the last two columns on the right side of Table 5.

The threshold value marking the limit between the two options, watering and replacement planting (main output variable $M$ ), varies significantly from case to case. The lowest decision threshold $M$ is that obtained for protection of hydraulic, road and rail infrastructures, fruticulture and truffle cultivation: 0.03 (in per unit). From that value onwards, watering is the economically more advantageous option. This value rises up to 0.625 (in per unit) in habitat restoration plantations. In timber plantations, intermediate values of $M$ are obtained, 0.30 (in per unit). On the other hand, the last year 
$(N)$ in which failures have to be replanted in order to reach the plant density that satisfies the acceptable level of seedling failure $(A L F)$, varies between one and three. Therefore, for the cases studied we get: $M \in(0.03,0.625)$ and $N \in(1,3)$. Obviously, both intervals can be wider if more extreme case studies are included.

In those cases, in which the value obtained for $M$ is close to zero, watering will be worth considering, as the expected level of failed seedlings within the area to be afforested will generally be higher than threshold $M$. On the contrary, high values for $M$ favour the option of failure replanting, except at forest sites where conditions for replanting are very adverse and the value of $M_{R}$ is even higher. Therefore, on specific and exceptional plantations similar to those of case studies 5, 6, 11, 12 and 13 watering is generally attractive. However, in the case of more common afforestations, more similar to case studies 2 and 4, replacement planting is the better option.

The unsupervised learning algorithm detects five groups. Figure 2 shows these five groups represented on a coordinate system.

Cases that yield a high income are in group I; they also have a very low acceptable level of seedling failure and a wide range of initial afforestation costs. This is common for plantations meant to protect roads, railways or hydraulic infrastructures; plantations of fruit trees; or oak (Quercus spp.) plantations mycorrhized to produce black truffles (Tuber nigrum). The interest of this group in the application of watering is very high (GI).

Group II comprises costly plantations with a very low acceptable level of seedling failure, but which yield a lower income than in group I. For this group, e.g., xerogardening projects, windbreaks and areas used to produce high-value non timber-forest products, such as high-quality edible mushrooms, watering might be of considerable interest (G-II).

Group III includes those cases that present medium levels of cost and income, and have a high level of acceptable seedling failure: timber producing plantations, multifunctional plantations, and plantations established in critical areas. The interest of this group in the application of watering would be moderate (G-III).

In group IV we find afforestations common in silviculture have a low expected future income and a high acceptable level of seedling failure. These are the conditions prevailing on plantations belonging to the European program for afforestation of marginal agricultural land. The interest of this group in watering is low (G-IV). Seedling replacement usually has advantage over watering.

Group V includes those afforestations have a low expected future income, and a high acceptable level of seedling failure. These are the conditions prevailing in most afforestations planned to restore the habitat in areas of low forest site quality. In this group, the interest in supplemental watering is quite low $(\mathrm{G}-\mathrm{V})$. Almost always, replacement planting is the economically most advantageous option, except when climate conditions are extreme (e.g., semi-desert or desert). 


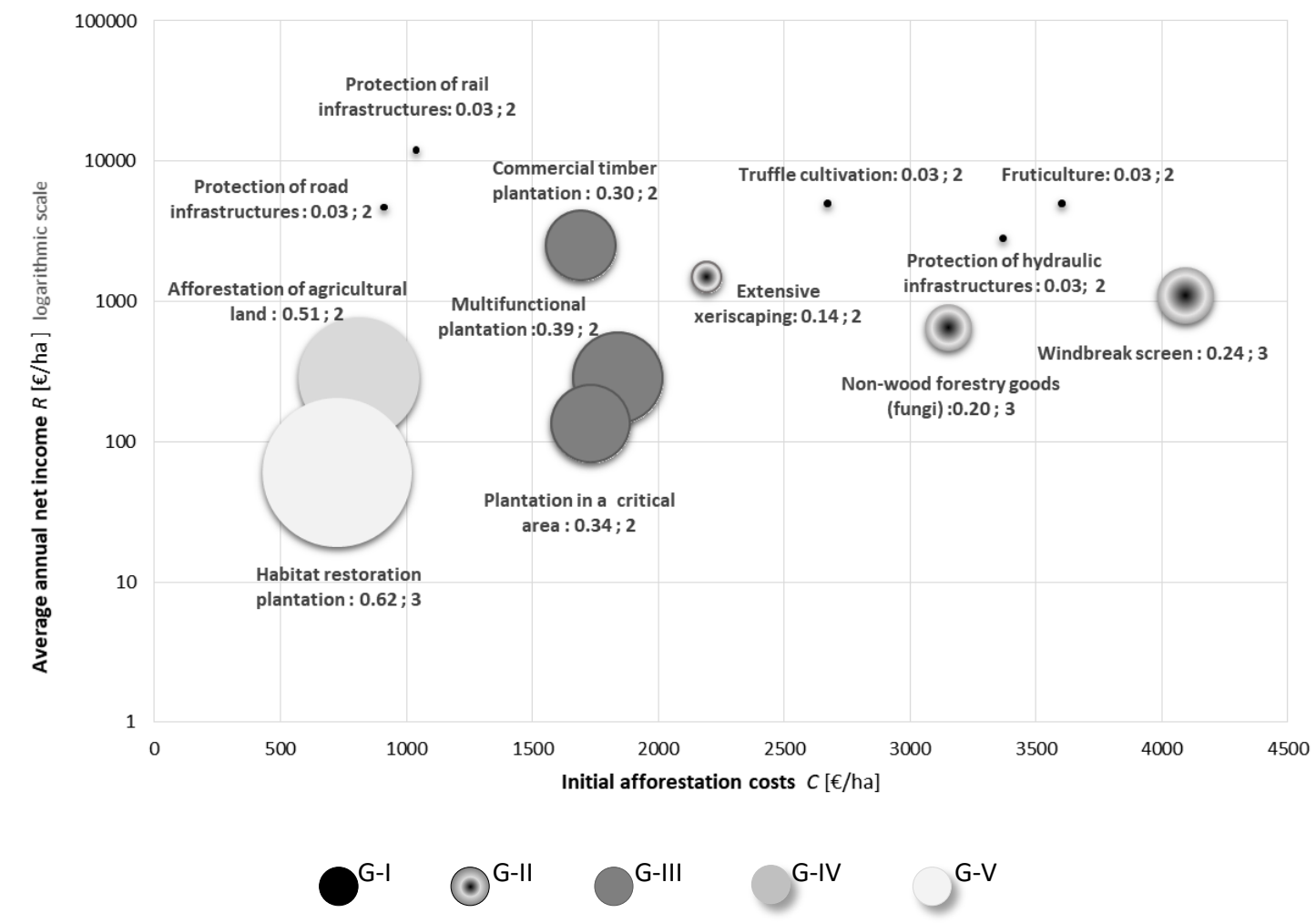

Figure 2. Position of the thirteen case studies in a coordinate system $(C, R)$ grouped by grayscale Notes:

The circle's area represents the threshold M; whose value appears on the label of each circle. The circle's grayscale indicates the group to which each plantation type. The label shows the name of the scenario, the value of $\mathrm{M}$ and, separated by a semicolon, the value of $\mathrm{N}$.

The abscissa shows the plantation cost $(C)$, while the ordinate reflects the average annual net income $(R)$ on a logarithmic scale. Cost $C$ is the initial investment made by the developer of the plantation. On the other hand, the income generated by the future woodland $R$ is a good indicator of the future economic and social importance of the afforestation (Masiero et al., 2015), as it considers the direct as well as the indirect benefits.

\subsection{Sensitivity analysis results}

The effect of each output variable on $M$ is shown on Table 6 (external column on the right side). 
Table 6. Range of the model's input variables and their effect on the value of $M$

\begin{tabular}{|c|c|c|c|c|c|}
\hline Variable & Unit & $\begin{array}{l}\text { Intervals (limits between brackets) } \\
\text { or individual values }\end{array}$ & $S_{i}$ & $S_{T i}$ & Effect \\
\hline$a$ & $€ \cdot \mathrm{ha}^{-1}$ & $(60,90)$ & 0.00 & 0.00 & (0) \\
\hline$A L F$ & in per unit & $(0.00,0.30)$ & 0.01 & 0.02 & $(+)$ \\
\hline$b$ & $€ \cdot$ plant $^{-1}$ & $(0.50,1.75)$ & 0.01 & 0.01 & $(-)$ \\
\hline$c$ & $€ \cdot$ plant $^{-1}$ & $(0.2,10.0)$ & 0.16 & 0.18 & $(--)$ \\
\hline$d$ & $€ \cdot$ plant $^{-1}$ & $(0.75,5.0)$ & 0.05 & 0.08 & $(+)$ \\
\hline$e$ & year & $5,20,40,60$ & 0.04 & 0.18 & $(++)$ \\
\hline$h$ & unitless & $(0.75,1.50)$ & 0.01 & 0.02 & $(-)$ \\
\hline$i$ & in per unit & $(0.00,0.15)$ & 0.05 & 0.15 & $(++)$ \\
\hline$n_{r i}$ & unitless & $1,2,3,4,5$ & 0.03 & 0.05 & $(+)$ \\
\hline$N R$ & L.plant ${ }^{-1}$.year ${ }^{-1}$ & $(5.0,100.0)$ & 0.05 & 0.09 & $(+)$ \\
\hline$R$ & $€ \cdot \mathrm{ha}^{-1}$ & $(30.0,12000.0)$ & 0.18 & 0.35 & $(--)$ \\
\hline$w$ & $€ \cdot L^{-1}$ & $(0.0,0.1)$ & 0.08 & 0.12 & $(++)$ \\
\hline$\varepsilon$ & year & $0,1,2,34$ & 0.01 & 0.08 & $(-)$ \\
\hline$\rho$ & plants.ha-1 & $(200,2500)$ & 0.04 & 0.12 & $(++)$ \\
\hline
\end{tabular}

Values and intervals based on case studies, table 1, table 4 and expert knowledge.

Effect: (+): $M$ increases when the variable's value does it, and (-): $M$ decreases when the variable's value increases. The variables that most influence $M$ are identified with a double addition or subtraction sign. The sign (0) indicates that the variable has almost no effect on $M$.

The value given to the effect each input variable has on the output variable $M$ is based on the variances $S_{T i}$ and $S_{i}$ (Sobol' 2001).

$M$ increases along with variables identified with (+), and diminishes along with variables identified with (-). The variables that most influence $M$ are identified with a double addition or subtraction sign. They are: cost per unit of seedling $(c,--)$, the plantation's profit or average annual net income $(R,--)$, watering costs $(w,++)$, time before coming into production $(e,++)$ and annual interest rate $(i,++)$, plantation density $(\rho,++)$.

Of all the above mentioned variables, average annual net income $R$ is the one with the strongest impact due to its wide range of input values and also because of its strong interaction with other input variables $(e, \varepsilon$ and $i)$. The following are, in order of importance, $c, e, i, \rho$ (Table 6$)$. The two variables of economic nature $(R, i)$ are those that contain the most uncertainty. If the future behaviour of the species that has been introduced is unknown, there will also be an uncertainty when setting the values of the temporal variables $e$ and $\varepsilon$.

\section{Discussion}

\subsection{Contributions of this model}

For the forestry sector, there is a consolidated economic procedure available that makes it possible to determine the optimal moment for felling a stand: the Faustmann- 
Preßler-Ohlin model (Johansson and Löfgren, 1985; Díaz-Balteiro, 1997). However, there is no equivalent proposal for the phase of seedling establishment, for which specific evaluations based on experiments or knowledge-based systems have been developed (Mason, 1995; Hobbs and Harris, 2001; Matthews et al., 2009; Kettenring and Adams, 2011; Löf et al., 2012; Robbins and Daniels, 2012).

The economy based decision support models for choosing among several silvicultural alternatives with a long-term focus compare the net present value obtained from a cost benefit analysis (e.g., Zhou, 1999). Short-term models resort to indexes based on cost-effectiveness analysis (e.g., Ahtikoski et al., 2010) or on avoided-cost models (e.g., Donovan and Brown, 2008).

However, in all cases, they make an economic comparison without interrelating the alternatives through some decision variable. For this reason, none of these models can resolve the question posed in this paper. The threshold of seedling failure $(M)$ is a variable crucial for decision making, as it connects both the alternatives we are considering: watering or replacement planting. This variable must be taken into account in order to make the correct decision. However, it is not taken into account by any of the current decision support models, nor can it be compensated by the inclusion of uncertainties.

Other approaches based on economic criteria and that are close to silviculture are the calculation of the economic threshold in integrated pest management (Stern et al., 1959; Pedigo et al., 1986; Bor, 1995), or some recommendations for technical change proposed in agronomy (CIMMYT, 1988). Our model and method differ from these proposals because it relies on cost-benefit analysis and introduces a decision rule that takes into account uncertainties $\left(M_{R}\right)$.

An important initial requirement before developing or applying any decision support model, is to clarify if we are in fact facing a decision making problem (Grünig and Kühn, 2009). According to these two authors, this is a preliminary question that many decision support models tend to forget, thereby reducing their practical value. In our opinion, MThreshold does not have this shortcoming, as it tackles the question directly in its decision rule when comparing the threshold of seedling failure $(M)$ with the expected level of seedling failure $\left(M_{R}\right)$.

The first output variable of MThreshold deals about seedling failures $(M) . M$ is a common indicator used in forestry management to evaluate the successful establishment of the first planting and to choose among possible alternatives during the phase of stand establishment (Ivetić, 2015). By resorting to the variable $M$, the model takes into account short-term criticism on the long-term focus, avoiding the use of indicators related only to a plantation's purpose and which are far away in time from the initial survival of the seedlings (Löf et al., 2012; Le et al., 2014; Jacobs et al., 2015). Simultaneously, the model keeps the focus on the long-term, as it considers the economic repercussion of failing and the effect of tending treatments on the profit $(\Delta B)$, as suggested by Mason (1995). 
The model's second output variable is the time $(N)$ needed to obtain, by replacement planting, a plant density that fits in well with the established acceptable level of seedling failure. Variable $N$ is interesting for stand establishment (Ahtikoski et al., 2010; Löf et al., 2012) when there is a legally established time limit for reaching and maintaining the target density, as the European Agricultural Fund for Rural Development $(E C, 2015)$ does. To find the value of $N$ we have developed an equation (eq 5) that determines the number of years of replacement planting needed to reach a plant density which is compatible with the acceptable level of seedling failure $(A L F)$.

MTthreshold uses just two output variables ( $M$ and $N)$. Both are closely related to forestry management and can therefore be easily interpreted by a forester. Furthermore, the input variables needed to calculate $M$ and $N$ are of common use in daily forestry practice.

All its input variables can be obtained from the information a plantation project should include. The description of the project, budget, technical specifications and economic evaluation are the documents that contain the data MThreshold requires: the unit costs of the different materials and works, the density of the plantation, the expected future net income, the time it will take to reach that annual income, and the annual interest rate.

The decision rule set out by the model compares the admissible threshold of seedling failure $(M)$ with the expected level of seedling failure $\left(M_{R}\right)$. This decision rule integrates the risk of seedlings dying off into the decision, as proposed by Hildebrandt and Knoke (2011), Yousefpour et al. (2012) and Pasalodos-Tato et al. (2013). This way, it is avoided that the model might offer results leading to suboptimal or wrong decisions (Duvemo and Lämås, 2006; Mechler, 2016), and that managers respond to an expected level of seedling failure over-reacting (knee-jerk response) or under-reacting (atrophy of vigilance) (Gardiner and Quine, 2000).

Although our economic model is a cost-benefit analysis, when the future annual net income of a plantation $(R)$ is uncertain or difficult to quantify, the term $\Delta B$ can be left out in equation [1]. This transforms our model into an avoided cost model (Del Río et al., 2013). However, this simplified approach is only suitable for plantations where the expected income is very low, as $M$ is very sensitive to changes of $R$. This has been proved by a sensitivity analysis. Input variable $R$, followed by the variables $c, e, i, \rho$ (in that order), has the greatest impact on $M$.

In order to improve the perception of the usefulness of the decision support models by potentially stakeholders (Gordon et al., 2014; Muys et al., 2010; Rinaldi et al., 2015) it may be convenient to explicitly state the hypotheses and calculation assumptions on which each model is based (Pastorella et al., 2016). That is what Díaz-Balteiro (1997), Newman (1988) and Kula (1988) have done with the decision support model based on optimal rotation. The rigorous explanation of a model's basis (Table 3, assumptions) is useful not only for specifying its limitations and present application range, but also for facilitating the model's adaptation to future demands. In this paper we focus on seedling 
watering, but the decision support model we are proposing can be used for other tending treatments (seed shelters, greenhouse pipes, mulching, weeding tools, use of herbicides, pruning, and other) as well.

\subsection{Advice for efficient watering}

The decision rule of the model establishes that watering has economic sense when the level of expected seedling failure $\left(M_{R}\right)$ is higher or equal to the obtained threshold value $(M)$. This would explain why, so far, watering techniques have not become more widespread in common afforestation projects (case study numbers 1, 2, 3, 4 and 9). In these cases, $M$ is usually high, which confirms the practice, widely extended among forest managers, of applying irrigation only in harsh sites. Only in such critical sites (Ruiz de la Torre et al., 1996) predicted failures will be higher than $M$ and, therefore, irrigation should be recommended.

It is worth mentioning two extreme situations in which watering is almost compulsory: when the expected level of seedling failure is close to one and/or the failing tolerance is strictly limited $(A L F \approx 0)$. Or, conversely, watering is usually not an interesting option if $M_{R}$ is low and/or the acceptable level of seedling failure is high (for example, if $A L F>0.5$ ).

$M_{R}$ will be close to one for afforestations in semi-desert or desert areas, even if we use local plant species. This is because, in such environments, natural regeneration will only seldom happen, as abundant rainfall is a rare phenomenon. The tamarugo tree (Prosopis tamarugo), the welwitschia plant (Welwitschia mirabilis) or the Saharan cipres (Cupressus dupreziana) are three examples that appropriately illustrate this extreme situation (Altamirano, 2006; Van Jaarsveld and Pond, 2013; Abdoun and Beddiaf, 2002; respectively, for each of the aforementioned species).

When there is a strict limit for failing tolerance (for example, imposed by the demands of the developer of the plantation, or when planting fast growing light demanding species) failed seedlings have to be replaced almost immediately, even during the same year (in $j=1$ ). Under these circumstances, and in arid climates, watering will be almost always the best option. Frequently, arboriculture and viticulture work under such demanding conditions. Truffle cultivation also commonly establishes a minimal or even zero failing tolerance. Case studies number 5, 6, 11, 12 and 13 follow this standard of very low thresholds of seedling failure $(M=0.03)$. This result supports the recommendations provided in technical publications (e.g., García-Viñas et al., 1993) of watering this type of plantations, since $M_{R}$ values in dryland sites are usually higher than 0.03 .

As a useful strategy, Batra and Pirard (2015) suggest classifying tree plantations into different types. The convenience of watering as analyzed in this paper could be a case in point. Groups have been defined according to the criteria of the value of $M$ and the value of the acceptable level of seedling failure $A L F$. The latter is a highly relevant input variable when designing a plantation, as it strongly affects the final density. Thus, 
the thirteen case studies we have analyzed form five functional typologies. Group I would show the highest interest in watering, followed by groups II, III and IV, with group $\mathrm{V}$ as the least interested.

Plantations with strict limits for failing tolerance $A L F$ favour a low admissible threshold of seedling failure $M$. In the extreme case of zero failing tolerance, the value of $M$ is also zero, a situation in which watering always results highly recommendable (Group I). A progressive increase of $A L F$ diminishes the interest on watering as the value of $M$ increases as well. Thus, the alternative option - seedling replacement - becomes more attractive, as is the case for groups IV and V. When the failing tolerance is intermediate (groups II and III), we observe that threshold $M$ decreases as the plant replacement costs $(C)$ and/or the average annual net income $(R)$ increase.

The results yielded by the model and the sensitivity analysis help explain why, so far, watering techniques have not become more widespread in regions where the value of $M_{R}$ is lower than the commonly accepted tolerance of failing replacement, and in plantations that fit into group III with mean values for $M$ close to the value of $A L F$.

On plantations that produce a high net income only a few years after having been established (low $e$ and high $R$ ), watering is the economically convenient option. Replaced failings reach productive age at a later point, therefore causing lost profit $\left(L P_{P V}\right)$. This advantage increases if watering allows an earlier extraction of benefits $\left(B I_{P V}\right)$ due to an earlier coming into production ( $\varepsilon$ years in advance). This is usually the case of plantations overview included in groups I and II.

Although to date we do not have international statistics on the value of $M_{R}$, the figures available for Spain (Tragsatec, 2008; Pemán and Vadell, 2009) show that in groups IV and V the use of watering is restricted to those critical areas where the foreseeable seedling mortality due to drought stress is very high.

Depending on the timing of the investment, an economic context with low interest rates (i) may favour the option of watering when compared to replacement planting. Watering (with $n_{r i}=1$ ) demands an important initial investment, and planners may be less reluctant to take up a loan if interest rates are low. On the other hand, the investments necessary for replacement planting can be divided into successive parts and distributed over a prolonged time, until reaching the year $N$.

Watering systems may vary greatly (Bainbridge, 2007; Martínez de Azagra and Del Río, 2012) and have a wide potential scope of application. The market for these systems is still quite small, but it seems likely that a more professional management of forest plantations, as well as the growing challenges of climate change, will motivate their use (Ivetić and Devetaković, 2016). It is therefore possible that watering systems may become cheaper which, in turn, may favour their widespread use (or at least their popularity) for forest restorations in arid areas, such as are included in groups III, IV and V. Lower prices (low $d$ ) will improve their competitiveness in regions with a low or 
medium expected level of seedling failure $\left(M_{R}\right)$. Moreover, the resulting accumulation of experience will allow our model to work with more precise input data.

\section{Appendix A. Description of the cost and benefit terms}

\section{A.1. Individualized cost equations}

The costs taken into account by this model are the acquisition and installation of the micro-irrigation system $(C d)$, the watering costs $(C w)$, the cost of the replanted seedlings $(C p)$, and the costs of the replanting works $(\mathrm{Cm})$. Table 2 includes all symbols and their meaning.

$$
\begin{array}{ll}
C_{w a t}=C d+C w_{P V} & (\mathrm{~A} 1) \equiv(2) \\
C_{r e p}=C p_{P V}+C m_{P V} & (\mathrm{~A} 2) \equiv(3)
\end{array}
$$

Where $P V$ is a subscript denoting cost discounted to present value.

\section{A.2 Acquisition and installation costs}

The calculation of the cost of buying and installing the selected micro-irrigation system $(C d)$ is based on its per unit price (factor $d$ ) and the plantation density ( $\rho$, number of plants/ha).

$$
C d=h \cdot d \cdot \rho
$$

The price of micro-irrigation devices varies widely. The cheapest systems are recycled PET bottles with wicks, buried vertical pipes, and porous irrigation capsules (approx. $1 € \cdot$ unit $^{-1}$ ), the most sophisticated are some plastic vessels with wicks like Ecobag $^{\circledR}$ or Waterboxx $^{\circledR}$ (approx.5 $€ \cdot$ unit $^{-1}$ ), with medium priced options like perforated horizontal pipes, clay pots, Konkoms, etc. (Table 1) The average price (d) has to be modified according to the accessibility and the transitability of the stand (factor $h$ ). A further factor to be taken into account when calculating the cost of installing a microirrigation system $(C d)$ is the cost of dismantling it (when it is not made of biodegradable material). On the other hand, it has to be taken into consideration whether the material could be re-used in other afforestation projects. In the latter case, the acquisition costs, implicit in parameter $d$, have to be divided by the number of plantations that may be irrigated using the same material.

\section{A.3. Watering costs}

The annual watering cost $\left(C w_{j}\right)$ is:

$$
C w_{j}=w_{j} \cdot N R_{j} \cdot \rho=w_{j} \cdot \operatorname{Dot}_{j}
$$

where $w_{j}$ is the unit price of irrigation for a given year $j\left(\right.$ in $\left.€ \cdot \mathrm{L}^{-1}\right)$ and it depends on the costs of the actual watering (irrigation method, labour, distance to the water source, pumping,...) and on the price of the water itself (in the case of volumetrical tariffs). $N R_{j}$ is the annual amount of water supplied by micro-irrigation to each seedling $\left(\mathrm{L} \cdot\right.$ plant $^{-1} \cdot$ year $\left.^{-1}\right)$, and $\rho$ is the plantation density (number of plants.ha ${ }^{-1}$ ). The water 
supply per hectare and year $\left(D o t_{j}\right)$ required by the micro-irrigation of seedlings or buried seeds is: $\operatorname{Dot}_{j}=\rho \cdot N R_{j}$

where $w_{j}$ is the unit price of irrigation for a given year $j\left(\right.$ in $\left.€ \cdot \mathrm{L}^{-1}\right)$ and it depends on the costs of the actual watering (irrigation method, labour, distance to the water source, pumping,...) and on the price of the water itself (in the case of volumetrical tariffs). $N R_{j}$ is the annual amount of water supplied by micro-irrigation to each seedling (L/plant/year), and $\rho$ is the plantation density (number of plants/ha). The water supply per hectare and year $\left(D o t_{j}\right)$ required by the micro-irrigation of seedlings or buried seeds is: $\operatorname{Dot}_{j}=\rho \cdot N R_{j}$

To update the annual costs to present value:

$$
C w_{P V}=\sum_{j=1}^{j=n_{r i}} \frac{C w_{j}}{(1+i)^{j-1}}=\sum_{j=1}^{j=n_{r i}} \frac{w_{j} \cdot D o t_{j}}{(1+i)^{j-1}}=\rho \cdot \sum_{j=1}^{j=n_{r i}} \frac{w_{j} \cdot N R_{j}}{(1+i)^{j-1}}
$$

where $i$ (in per unit) is the interest rate and $n_{r i}$ the number of years seedlings are irrigated.

Watering may be extended for a period of time $(\Delta n=0,1,2,3 \ldots$ years $)$ after initial implantation. A value for $\Delta n$ equal to naught is usually sufficient in Mediterranean climates but under more extreme conditions, or in the case of species with a slow root growth, it may be convenient to prolong micro-irrigation for some time $(\Delta n>0)$. The following relation applies:

$$
n_{r i}=1+\Delta n
$$

\section{A.4. Plant replacement costs}

$$
C p_{j}=c_{j} \cdot \rho \cdot M^{j-1}
$$

where $C p_{j}$ is the annual unit price of the seedling (or of the seeds buried at each point) (in $€ \cdot$ plant $^{-1}$ or $€ \cdot$ seed $^{-1}$ ) that depends on its availability on the market, on the species and on the type of plant, $\rho$ is the initial plantation density (plants or points. $\mathrm{ha}^{-1}$ ), $\mathrm{M}$ is the threshold value of failed seedlings (in per unit), and $\rho \cdot M^{j-1}$ is the number of plants per hectare that have to be replaced to complete (restore) the initial plantation density.

To update the annual costs to present value:

$$
C p_{P V}=\sum_{j=2}^{j=N} \frac{C p_{j}}{(1+i)^{j-1}}=\rho \cdot \sum_{j=2}^{j=N} \frac{c_{j} \cdot M^{j-1}}{(1+i)^{j-1}}
$$

\section{A.5. Labour costs of the replacement of failed seedlings}

The annual labour costs of the replacement of failed seedlings are:

$$
C m_{j}=a_{j}+b_{j} \cdot \rho \cdot M^{j-1}
$$

A linear model is used because it underlies most professional catalogues of unit prices for labour in forestry. Factor $a_{j}$ is an adjustment coefficient (in $€ \cdot h a^{-1}$ in a given year $j$ ) and $b_{j}$ is the second coefficient of the linear model (in $€ \cdot$ plant $^{-1}$ in a given year $\mathrm{j}$ ). Both coefficients depend on the complexity of the execution of the replacement, the type of soil preparation, and the type of plant. Again, $M$ is the threshold value of failed seedlings (in per unit), and $\rho$ the plantation density (plants $\cdot$ ha $^{-1}$ ). 
To update the annual costs to present value:

$$
C m_{P V}=\sum_{j=2}^{j=N} \frac{a_{j}+b_{j} \cdot \rho \cdot M^{j-1}}{(1+i)^{j-1}}
$$

\section{A.6. Difference between the expected benefits for each option}

The difference between the benefits of both options is calculated for each year $\left(\Delta B_{j}\right)$.

Its expression in present value $(\Delta B)$ is obtained subsequently:

$$
\begin{aligned}
& \Delta B_{j}=B w_{j}-B r_{j} \\
& \Delta B=\sum_{j=\alpha}^{j=\beta} \frac{\Delta B_{j}}{(1+i)^{j-1}}
\end{aligned}
$$

where $B w_{j}$ is the annual benefit (income) of the forest in a given year $j$ if plantation has been supported by watering; $B r_{j}$ the annual benefits (income) of the forest in a given year $j$ if the traditional alternative of replacing failed seedlings has been followed; $\alpha$ and $\beta$ represent the years (respectively, the first and the last) in which the benefits yielded by each alternative differ.

If we call $e$ the sequence number of the year in which the afforestation begins to produce economically quantifiable goods and services $(j=e)$ without irrigation, it is convenient to break down $\Delta B$ into two terms: the early benefits obtained thanks to watering $\left(B I_{P V}\right)$, and the lost profits $(L P P V)$ due to seedling failure.

$$
\Delta B=\sum_{j=\alpha}^{j=\beta} \frac{\Delta B_{j}}{(1+i)^{j-1}}=B I_{P V}+L P_{P V}
$$

Combining latter expression (A.13) with the model's general inequation (1) we obtain:

$$
C_{\text {wat }}-B I_{P V} \leq C_{\text {rep }}+L P_{P V} \quad(\mathrm{~A} 14) \equiv(1)
$$

A simple way of assessing all the summands in afforestations is $R$, the average income produced by a forest with traits similar to those achieved with the afforestation project.

\section{A.7 Early benefits}

A forest can begin to be productive earlier thanks to the support irrigation it has received when it was planted (and during its subsequent growth, if irrigation was continued). Instead of beginning to be productive in the year $j=e$, it begins to be productive $\varepsilon$ years earlier (i.e. in $j=\alpha=e-\varepsilon$ ), an additional advanced production that has to be rolled back to the initial year $(j=1)$.

For a constant $\Delta B_{j}=R$ the additional benefit is:

$$
B I_{P V}=R \cdot \sum_{j=e-\epsilon}^{j=e-1} \frac{1}{(1+i)^{j-1}}
$$




\section{A.8. Lost profit due to the replacement of failures}

The replacing of failed seedlings creates a forest stand where plants of different ages coexist. On reaching the age $e$, every successfully replaced plant successively begins to produce goods and/or services. If the benefits produced by a forest are assumed to be proportional to the number of trees per hectare that have been growing in the forest for $j=e$ years (or more), the number of trees that have not yet reached this age (due to $M$ failure of seedlings) is the income lost in the year $j\left(L P_{j}\right)$.

$L P_{j}=R \cdot M^{j-e+1}$

where $e \leq j \leq \beta=e+N-1$

When this lost income is rolled back to the year of planting, we get

$$
L P_{P V}=R \cdot \sum_{j=e}^{j=e+N-2} \frac{M^{j-e+1}}{(1+i)^{j-1}}
$$

\section{References}

Abdoun F, Beddiaf M (2002) Cupressus dupreziana A. Camus: répartition, dépérissement et régénération au Tassili n'Ajjer, Sahara central. Comptes Rendus Biologies 325 (5):617-627. doi:S16310691(02)01433-6

Ahtikoski A, Alenius V, Mäkitalo K (2010) Scots pine stand establishment with special emphasis on uncertainty and cost-effectiveness, the case of northern Finland. New Forests 40 (1):69-84. doi:10.1007/s11056-009-9183-2

Alrababah MA, Bani-Hani MG, Alhamad MN, Bataineh MM (2008) Boosting seedling survival and growth under semi-arid Mediterranean conditions: Selecting appropriate species under rainfed and wastewater irrigation. Journal of Arid Environments 72 (9):1606-1612. doi:10.1016/j.jaridenv.2008.03.013

Altamirano H (2006) Prosopis tamarugo Phil. Tamarugo. In Donoso, C. (eds) Las especies arbóreas de los bosques templados de Chile y Argentina Autoecología. Marisa Cuneo Ediciones, Valdivia, pp 534540

Bainbridge DA, Fidelibus M, MacAller R (1995) Techniques for plant establishment in arid ecosystems. Restoration and Management Notes 13:190-197. doi:10.3368/er.13.2.190

Bainbridge DA (2002) Alternative watering systems for arid land restoration. Ecological Restoration 20 (1):23-30. doi:10.3368/er.20.1.23

Bainbridge DA (2007) A guide for desert and dryland restoration: new hope for arid lands. Island Press, Washington

Baker F (1955) California's forest regeneration problems. Department of Natural Resources, Division of Forestry, State Board of Forestry, Regeneration Committee. Sacramento

Bare BB, Weintraub A (2015) Brief history of systems analysis in forest resources. Annals of Operations Research 232 (1):1-10. doi:10.1007/s10479-015-1897-2

Batra P, Pirard R (2015) Is a typology for planted forests feasible, or even relevant? Center for International Forestry Research (CIFOR), Bogor, Indonesia. doi:10.17528/cifor/005608

Bean TM, Smith SE, Karpiscak MM (2004) Intensive revegetation in Arizona's Hot Desert: The advantages of container stock. Native Plants Journal 5 (2):173-180. doi:10.2979/npj.2004.5.2.173

Beecher JA (1996) Avoided cost: an essential concept for integrated resource planning. Journal of Contemporary Water Research and Education 104 (1):28-35 
Birch JC, Newton AC, Aquino CA, Cantarello E, Echeverría C, Kitzberger T, Schiappacasse I, Garavito NT (2010) Cost-effectiveness of dryland forest restoration evaluated by spatial analysis of ecosystem services. Proceedings of the National Academy of Sciences 107 (50):21925-21930. doi:10.1073/pnas.1003369107

Bor YJ (1995) Optimal pest management and economic threshold. Agricultural Systems 49 (2):113-133. doi:10.1016/0308-521X (94)00043-Q

Borges JG, Nordström EM, Garcia J, Hujala T, Trasobares A (2014) Computer-based tools for supporting forest management. The Experience and the Expertise World-Wide. Department of Forest Resource Management, Swedish University of Agricultural Sciences, Umeå, Sweden

Burdett AN (1990) Physiological processes in plantation establishment and the development of specifications for forest planting stock. Canadian Journal of Forest Research 20 (4):415-427. doi:10.1139/x90-059

Çalişkan S, Boydak M (2017) Afforestation of arid and semiarid ecosystems in Turkey. Turkish Journal of Agriculture and Forestry 41 (5):317-329. doi:10.3906/tar-1702-39

Catalina MA, Vicente C (2001) Rentabilidad y sostenibilidad de las acciones de corrección hidrológicoforestales. In Sociedad Española de las Ciencias Forestales, Junta de Andalucía (eds) III Congreso Forestal Español Montes para la Sociedad del Nuevo Milenio. Gráficas Coria, Sevilla

Chunfeng W, Chokkalingam U (2006) National overview. In Chokkalingam U, Zaichi Z, Chunfeng W, Toma $\mathrm{T}$ (eds) Learning Lessons from China's Forest Rehabilitation Efforts: National Level Review and Special Focus on Guangdong Province. Center for International Forestry Research (CIFOR), Bogor, Indonesia

CIMMYT (1988) La formulación de recomendaciones a partir de datos agronómicos: Un manual metodológico de evaluación económica. CIMMYT, Mexico

Consejería de Medio Ambiente (2005) Castilla y León crece con el bosque. Junta de Castilla y León, Valladolid

Crous JW (2016) Use of hydrogels in the planting of industrial wood plantations. Southern Forests: a Journal of Forest Science 1-17. doi:10.2989/20702620.2016.1221698

Del Río J, Gómez E, Reque JA, Martínez de Azagra A (2013) Reponer marras o regar brinzales: una disyuntiva a analizar en zona árida. In Martínez C, Lario F, Fernández B (eds) Avances en la restauración de sistemas forestales Técnicas de implantación. Sociedad Española de las Ciencias Forestales, Asociación Española de Ecología Terrestre, pp 13-18

Del Río J, Reque JA, Martínez de Azagra A (2016) Viabilidad económica de los microrriegos en repoblaciones. Cuadernos de la Sociedad Española de las Ciencias Forestales (42):75-90

Díaz-Balteiro L (1997) Turno forestal económicamente óptimo: una revisión. Revista Española de Economía Agraria 180:181-224

Díaz-Balteiro L, Alfranca O, Voces R (2013) Mercado de Lactarius deliciosus. Modelización de la oferta en España. Información Técnica Económica Agraria 109 (3):370-398

Díaz-Balteiro L, Romero C (2008) Making forestry decisions with multiple criteria: A review and an assessment. Forest Ecology and Management 255 (8):3222-3241. doi:10.1016/j.foreco.2008.01.038

Djanibekov U, Khamzina A (2016) Stochastic Economic Assessment of Afforestation on Marginal Land in Irrigated Farming System. Environmental and Resource Economics 63 (1):95-117. doi:10.1007/s10640014-9843-3

Donovan GH, Brown TC (2008) Estimating the avoided fuel-treatment costs of wildfire. Western Journal of Applied Forestry 23(4):197-201

Duvemo K, Lämås T (2006) The influence of forest data quality on planning processes in forestry. Scandinavian Journal of Forest Research 21 (4):327-339. doi:10.1080/02827580600761645 
Eid T (2000) Use of uncertain inventory data in forestry scenario models and consequential incorrect harvest decisions. Silva Fennica 34 (2):89-100

European Comission and European Investment Bank (2016) Methodological handbook for implementing an ex-ante assessment of agriculture financial instruments under the EAFRD. https://www.ficompass.eu/sites/default/files/publications/209775_EAFRD_EXANTE_ASSESSMENT_HANDBOO K_0.pdf. Accessed 21 March 2017

EC (2015) Regulation (EU) No 1305/2013 of the European Parliament and of the Council of 17 December 2013 on support for rural development by the European Agricultural Fund for Rural Development (EAFRD) and repealing Council Regulation (EC) No 1698/2005. Official Journal of the European Union OJ L 347, 20.12.2013, pp 487-548

FAO (2005) Global Forest Resource Assessment 2005: Progress Toward Sustainable Forest Management. In: FAO Forestry Paper 147. Food and Agriculture Organization, Roma, Italy

Fernández FJ, Vázquez J (2012) Costes de las líneas de alta velocidad internalizados en la contabilidad del administrador de infraestructuras. Revista de alta velocidad 360 (2):5-22

García JI, Carreras C, Orti M (1993) Instalación de cubierta vegetal en taludes de obras en zonas áridas. Informes de la Construcción 45 (425-426):85-93

Gardiner BA, Quine CP (2000) Management of forests to reduce the risk of abiotic damage-a review with particular reference to the effects of strong winds. Forest Ecology and Management 135 (1):261-277

Gilliams S, Raymaekers D, Muys B, Orshove, JV (2005) Comparing multiple criteria decision methods to extend a geographical information system on afforestation. Computers and Electronics in Agriculture 49 (1):142-158. doi:10.1016/j.compag.2005.02.011

Gordon SN, Floris A, Boerboom L, Lämås T, Eriksson LO, Nieuwenhuis M, Garcia J, Rodriguez L (2014) Studying the use of forest management decision support systems: an initial synthesis of lessons learned from case studies compiled using a semantic wiki. Scandinavian Journal of Forest Research 29 (sup1) 44-55. doi:10.1080/02827581.2013.856463

Graham V, Laurance SG, Grech A, McGregor A, Venter O (2016) A comparative assessment of the financial costs and carbon benefits of REDD+ strategies in Southeast Asia. Environmental Research Letters 11 (11):114022

Grantz DA, Vaughn DL, Farber RJ, Kim B, Ashbaugh L, VanCuren T, Campbell R, Bainbridge D, Zink T (1998) Transplanting Native Plants to Revegetate Abandoned Farmland in the Western Mojave Desert. Journal of Environmental Quality 27 (4):960-967. doi:10.2134/jeq1998.00472425002700040033x

Grêt-Regamey A, Sirén E, Brunner SH, Weibe, B (2017) Review of decision support tools to operationalize the ecosystem services concept. Ecosystem Services 26 (Part B):306-315. doi:10.1016/j.ecoser.2016.10.012

Grünig R, Kühn R (2009) Successful Decision-making. A Systematic Approach to Complex Problems. 2nd edn. Springer-Verlag Berlin Heidelberg, Berlin. doi:10.1007/978-3-642-00854-2_11

Hanewinkel M (2009) The role of economic models in forest management. CAB Reviews: Perspectives in Agriculture, Veterinary Science, Nutrition and Natural Resources 4 (031):1-10

Hanley N, Spash CL (1993) The value of biodiversity in British forests. Report to the Forestry Commission. University of Stirling, Scotland

Hawkins CB, Steele TW, Letchford T (2006) The economics of site preparation and the impacts of current forest policy: evidence from central British Columbia. Canadian Journal of Forest Research 36 (2):482494. doi:10.1139/x05-262

Hildebrandt P, Knoke T (2011) Investment decisions under uncertainty - A methodological review on forest science studies. Forest Policy and Economics 13 (1):1-15. doi:10.1016/j.forpol.2010.09.001

Hyytiäinen K, Ilomäki S, Mäkelä A, Kinnunen K (2006) Economic analysis of stand establishment for Scots pine. Canadian Journal of Forest Research 36 (5):1179-1189. doi:10.1139/x06-023 
Hobbs RJ, Harris JA (2001) Restoration ecology: repairing the earth's ecosystems in the new millennium. Restoration Ecology 9 (2):239-246. doi:10.1046/j.1526-100x.2001.009002239.x

Ingles A, Shepherd G, Applegate G, Parrotta J, Poulsen J, Evans J, Bazett M, Dudley N, Nasi R, Mansourian $S$ (2002) Typology of planted forests. Center for International Forestry Research (CIFOR), Bogor, Indonesia

Ivetić V (2015) Reforestation in Serbia: success or failure? In: International Conference: Reforestation Challenges, Belgrade, Serbia, 3-6 June 2015 Proceedings, 2015. REFORESTA, pp 1-12

Ivetić V, Devetaković J (2016) Reforestation challenges in Southeast Europe facing climate change. Reforesta 1:178-220. doi:10.21750/10.21750/refor.1.10.10

Jacobs DF, Oliet JA, Aronson J, Bolte A, Bullock JM, Donoso PJ, Landhäusser SM, Madsen P, Peng S, Rey JM, Weber JC (2015) Restoring forests: What constitutes success in the twenty-first century? New Forests 46 (5):601-614. doi:10.1007/s11056-015-9513-5

Johansson PO, Löfgren KG (1985) The economics of forestry and natural resources. Basil Blackwell, Oxford

Johnson KN, Gordon S, Duncan S, Lach D, McComb B, Reynolds K (2007) Conserving Creatures of the Forest: A Guide to Decision Making and Decision Models for Forest Biodiversity

Kangas J, Kangas A (2005) Multiple criteria decision support in forest management - the approach, methods applied, and experiences gained. Forest Ecology and Management 207 (1):133-143. doi:10.1016/j.foreco.2004.10.023

Kettenring KM, Adams CR (2011) Lessons learned from invasive plant control experiments: a systematic review and meta-analysis. Journal of Applied Ecology 48 (4):970-979. doi:10.1111/j.13652664.2011.01979.x

Kula E (1988) Future generations: the modified discounting method. Project Appraisal 3 (2):85-88. doi:10.1080/02688867.1988.9726662

Le HD, Smith C, Herbohn J (2014) What drives the success of reforestation projects in tropical developing countries? The case of the Philippines. Global Environmental Change 24 (Supplement C) 334-348. doi:10.1016/j.gloenvcha.2013.09.010

Lexer MJ, Vacik H, Palmetzhofer D, Oitzinger G (2005) A decision support tool to improve forestry extension services for small private landowners in southern Austria. Computers and Electronics in Agriculture 49 (1):81-102. doi:10.1016/j.compag.2005.02.004

Löf M, Dey DC, Navarro RM, Jacobs DF (2012) Mechanical site preparation for forest restoration. New Forests 43 (5-6):825-848. doi:10.1007/s11056-012-9332-x

Macmillan DC, Harley D, Morrison R (1998) Cost-effectiveness analysis of woodland ecosystem restoration. Ecological Economics 27 (3):313-324. doi:10.1016/S0921-8009(98)00023-8

Martell DL, Gunn EA, Weintraub A (1998) Forest management challenges for operational researchers. European journal of operational research 104 (1):1-17

Martínez de Azagra A, Del Río J (2012) Los riegos de apoyo y de socorro en repoblaciones forestales. Foresta 53:32-44

Martínez F, Oria de Rueda J, Ágreda T (2011) Manual para la gestión del recurso micológico forestal en Castilla y León. Serie Técnica de la Junta de Castilla y León.

Masiero M, Secco L, Pettenella D, Brotto L (2015) Standards and guidelines for forest plantation management: A global comparative study. Forest Policy and Economics 53:29-44. doi:10.1016/j.forpol.2014.12.008

Mason E (1995) Decision tools for establishing forest plantations. In: Power JM, Strome M, Daniel TC (eds) Proceedings of Decision-support 2001 Conference, Toronto, Canada, September 12-16, pp 634-648

Mason EG, Whyte AGD, Woollons RC, Richardson B (1997) A model of the growth of juvenile radiata pine in the Central North Island of New Zealand: links with older models and rotation-length analyses of 
the effects of site preparation. Forest Ecology and Management 97 (2):187-195. doi:10.1016/S03781127(97)00099-6

Mason EG, Dzierzon H (2006) Applications of modeling to vegetation management. Canadian Journal of Forest Research 36 (10):2505-2514. doi:10.1139/x06-191

Matthews JW, Spyreas G, Endress G (2009) Trajectories of vegetation-based indicators used to assess wetland restoration progress. Ecological Applications 19(8):2093-2107. doi:10.1890/08-1371.1

Mechler R (2016) Reviewing estimates of the economic efficiency of disaster risk management: opportunities and limitations of using risk-based cost-benefit analysis. Natural Hazards 81 (3):2121-2147. doi:10.1007/s11069-016-2170-y

Miller JR, Hobbs RJ (2007) Habitat restoration-do we know what we're doing? Restoration Ecology 15 (3):382-390 doi:10.1111/j.1526-100X.2007.00234.x

Ministerio de Fomento (2014) Mapa de tráfico 2014. Tráfico en la red de carreteras. http://www.fomento.es/NR/rdonlyres/D792FCCC-A6DF-4DAA-9170806C611D4CC4/133563/MapaIntensidad2014bueno.pdf. Accessed 13 May 2017

Ministerio de Medio Ambiente y Medio Rural y Marino (2011) Resumen provincial del valor económico y la renta anual de la superficie forestal arbolada según la metodología del IFN3. http://www.mapama.gob.es/es/biodiversidad/servicios/banco-datos-naturaleza/informaciondisponible/tablas_resumen_IFN3.aspx. Accessed 13 May 2017

Molina F, Dans F, Fernández de Ana F, Molina B (2014) Guía de silvicultura. Producción de madera de alto valor: El nogal. Ed. Asociación Forestal de Galicia - COSE

Morcillo M, Sánchez M, Vilanova X (2015) Cultivar trufas, una realidad en expansión. Micología Forestal Aplicada SL, Spain

Muncharaz M (2012) El nogal. Técnicas de producción de fruto y madera. MundiPrensa. Madrid

Murphy T (1989) Planting in extreme climates. Journal of Arid Lands Permaculture 8 (1):6-7

Muys B, Hynynen J, Palahi M, Lexer MJ, Fabrika M, Pretzsch H, Gillet F, Briceño E, Nabuurs GJ, Kint V (2010) Simulation tools for decision support to adaptive forest management in Europe. Forest Systems 19:86-99

Newman DH (1988) The optimal forest rotation: A Discussion and Annotated Bibliography. General Technical Report. USDA Southeastern Forest Experiment Station, Asheville

Nobre S, Eriksson LO, Trubins R (2016) The Use of Decision Support Systems in Forest Management: Analysis of FORSYS Country Reports. Forests 7 (3):72

Oliet JA, Planelles R, Artero F, Domingo-Santos JM (2016) Establishing Acacia salicina under dry Mediterranean conditions: The effects of nursery fertilization and tree shelters on a mid-term experiment with saline watering. Ciencia e Investigación Agraria 43 (1):69-84. doi:10.4067/S071816202016000100007

Pasalodos, M, Mäkinen A, Garcia J, Borges J, Lämås T, Eriksson L (2013) Assessing uncertainty and risk in forest planning and decision support systems: review of classical methods and introduction of new approaches. Forest Systems 22 (2):282-303

Pasalodos M, Pukkala T, Calama R, Cañellas I, Sánchez M (2016) Optimal management of Pinus pinea stands when cone and timber production are considered. European Journal of Forest Research 135 (4):607619. doi:10.1007/s10342-016-0958-7

Pastorella F, Borges J, De Meo I (2016) Usefulness and perceived usefulness of Decision Support Systems (DSSs) in participatory forest planning: the final users in participatory forest planning: the final users' point of view. iForest - Biogeosciences and Forestry 9 (3):422-429. doi:10.3832ifor1356-008

Pedigo LP, Hutchins SH, Higley LG (1986) Economic injury levels in theory and practice. Annual Review of Entomology 31 (1):341-368 
Pemán J, Vadell E (2009) Reconstrucción de la estadística de la actividad repobladora desde 1879 hasta nuestros días [cd-rom]. In Sociedad Española de Ciencias Forestales, Junta de Castilla y León (eds) Actas del $5^{\circ}$ Congreso Forestal Español. Ávila

Peri P, Bloomberg M (2002) Windbreaks in southern Patagonia, Argentina: A review of research on growth models, windspeed reduction, and effects on crops. Agroforestry Systems 56 (2):129-144. doi:10.1023/A:1021314927209

Peri P, Pastur GM (1998) Crecimiento en cortinas cortavientos de Populus nigra en Patagonia Sur (Argentina). Investigación Agraria Sistemas y Recursos Forestales 7 (1):73-84

Peterson DW, Dodson EK, Harrod RJ (2009) Fertilization and seeding effects on vegetative cover after wildfire in north-central Washington State. Forest Science 55 (6):494-502

Pinto JR, Marshall JD, Dumroese RK, Davis AS, Cobos DR (2016) Seedling establishment and physiological responses to temporal and spatial soil moisture changes. New Forests 47 (2):223-241. doi:10.1007/s11056-015-9511-7

Prinz D (2001) Water harvesting for afforestation in dry areas. In Proceedings, 10th international conference on rainwater catchment systems. Mannheim, Germany, pp 195-198

Pywell RF, Bullock JM, Tallowin JB, Walker KJ, Warman EA, Masters G (2007) Enhancing diversity of species-poor grasslands: an experimental assessment of multiple constraints. Journal of Applied Ecology 44 (1):81-94. doi:10.1111/j.1365-2664.2006.01260.x

Pukkala T (1998) Multiple risks in multi-objective forest planning: integration and importance. Forest Ecology and Management 111 (2):265-284

Reynolds KM, Twery M, Lexer MJ, Vacik H, Ray D, Shao G, Borges JG (2008) Decision Support Systems in Forest Management. In: Handbook on Decision Support Systems 2: Variations. Springer Berlin Heidelberg, Berlin, Heidelberg, pp 499-533. doi:10.1007/978-3-540-48716-6_24

Richardson B, Watt MS, Mason EG, Kriticos DJ (2006) Advances in modelling and decision support systems for vegetation management in young forest plantations. Forestry: An International Journal of Forest Research 79 (1):29-42. doi:10.1093/forestry/cpi059

Rinaldi F, Jonsson R, Sallnäs O, Trubins R (2015) Behavioral modelling in a decision support system. Forests $6(2): 311-327$

Robbins AST, Daniels JM (2012) Restoration and Economics: A Union Waiting to Happen? Restoration Ecology 20 (1):10-17. doi:10.1111/j.1526-100X.2011.00838.x

Rönnqvist M, D'Amours S, Weintraub A, Jofre A, Gunn E, Haight RG, Martell D, Murray AT, Romero C (2015) Operations Research challenges in forestry: 33 open problems. Annals of Operations Research 232 (1):11-40. doi:10.1007/s10479-015-1907-4

Ruiz De la Torre J, Carreras C, García JI, Orti M (1996) Manual de la flora para la restauración de áreas críticas y diversificación en masas forestales. Consejería de Medio Ambiente de la Junta de Andalucía, Sevilla

Salado F, Astals F (2010) Estudio de los costes totales, incluyendo las externalidades, del AVE: Aplicación al caso Barcelona-Madrid y comparación con otros modos de transporte. Universitat Politècnica de Catalunya, Terrasa

Sánchez J, Ortega R, Hervás M, Padilla F, Pugnaire F (2004) El microrriego, una técnica de restauración de la cubierta vegetal para ambientes semiáridos. Cuadernos de la Sociedad Española de Ciencias Forestales 17:109-112

Saltelli A (2002) Making best use of model evaluations to compute sensitivity indices. Computer Physics Communications 145 (2):280-297. doi:10.1016/S0010-4655(02)00280-1

Saltelli A, Annoni P, Azzini L, Campolongo F, Ratto M, Tarantola S (2010) Variance based sensitivity analysis of model output. Design and estimator for the total sensitivity index. Computer Physics Communications 181 (2):259-270. doi:10.1016/j.cpc.2009.09.018 
Sánchez J, Ortega R, Hervás M, Padilla F, Pugnaire F (2004) El microrriego, una técnica de restauración de la cubierta vegetal para ambientes semiáridos. Cuadernos de la Sociedad Española de Ciencias Forestales 17:109-112

Segura M, Ray D, Maroto C (2014) Decision support systems for forest management: A comparative analysis and assessment. Computers and Electronics in Agriculture 101:55-67. doi:10.1016/j.compag.2013.12.005

Snider G, Daugherty PJ, Wood D (2006) The Irrationality of Continued Fire Suppression: An Avoided Cost Analysis of Fire Hazard Reduction Treatments Versus No Treatment. Journal of Forestry 104 (8):431437

Sobol' IM (2001) Global sensitivity indices for nonlinear mathematical models and their Monte Carlo estimates. Mathematics and Computers in Simulation 55 (1-3):271-280. doi:10.1016/S03784754(00)00270-6

Socias R, Couceiro JF (2014) Frutos secos. Almendro y pistachero. In Hueso JJ, Cuevas J (eds) La fruticultura del siglo XXI en España. Cajamar Caja Rural

Squeo FA, Holmgren M, Jiménez M, Albán L, Reyes J, Gutiérrez JR (2007) Tree establishment along an ENSO experimental gradient in the Atacama Desert. Journal of Vegetation Science 18 (2):195-202. doi:10.1658/1100-9233

Stern VM, Smith RF, Van den Bosch R, Hagen KS (1959) The integration of chemical and biological control of the spotted alfalfa aphid. The integrated control concept. Hilgardia 29 (2):81-101. doi:10.3733/hilg.v29n02p081

Tibshirani R, Walther G, Hastie T (2001) Estimating the number of clusters in a data set via the gap statistic. Journal of the Royal Statistical Society: Series B (Statistical Methodology) 63 (2):411-423. doi:10.1111/1467-9868.00293

Tragsatec (2008) Evaluación final del programa de desarrollo rural para las medidas de acompañamiento en España 2000-2006. Ministerio de Medio Ambiente Medio rural y Marino. Madrid

Thorsen BJ, Helles F (1998) Optimal stand management with endogenous risk of sudden destruction. Forest Ecology and Management 108 (3):287-299

Uotila K, Rantala J, Saksa T, Harstela P (2010) Effect of soil preparation method on economic result of Norway spruce regeneration chain. Sylva Fennica 44 (3):511-524. doi:10.14214/sf.146

Vacik H, Lexer MJ (2014) Past, current and future drivers for the development of decision support systems in forest management. Scandinavian Journal of Forest Research 29 (sup1):2-19. doi:10.1080/02827581.2013.830768

Vadell E, de-Miguel S, Pemán J (2016) Large-scale reforestation and afforestation policy in Spain: A historical review of its underlying ecological, socioeconomic and political dynamics. Land Use Policy 55:37-48. doi:10.1016/j.landusepol.2016.03.017

Van Jaarsveld EJ, Pond U (2013) Uncrowned Monarch of the Namib: Welwitschia mirabilis. Penrock publications, Cape Town

Vargas P (2012) Tecnología de riego por succión. Primeras experiencias en Cuba. Editorial Académica Española, Saarbrücken

Wainger LA, King DM, Mack RN, Price EW, Maslin T (2010) Can the concept of ecosystem services be practically applied to improve natural resource management decisions? Ecological Economics 69 (5):978-987. doi:10.1016/j.ecolecon.2009.12.011

Weintraub A, Romero C (2006) Operations research models and the management of agricultural and forestry resources: a review and comparison. Interfaces 36 (5):446-457

Yousefpour R, Jacobsen JB, Thorsen BJ, Meilby H, Hanewinkel M, Oehler K (2012) A review of decisionmaking approaches to handle uncertainty and risk in adaptive forest management under climate change. Annals of Forest Science 69 (1):1-15. doi:10.1007/s13595-011-0153-4 
Zhou W (1999) Risk-based selection of forest regeneration methods. Forest Ecology and Management 115 (1):85-92

\section{Adenda. Elementos de apoyo para la utilización del sistema de ayuda a la toma de decisiones MThrehold}

En esta adenda se orienta de manera práctica a presentar información y algunas herramientas que faciliten al gestor, proyectista o industrial, la aplicación del modelo. En concreto se presentan consideraciones sobre cómo calcular algunas de las variables selvícolas de entrada del modelo, se obtienen los rangos de los umbrales de decisión para cada grupo de aptitud al riego y se plantean hipótesis sobre las causas de las marras a partir de los resultados del modelo.

\section{Consideraciones sobre algunas variables de diseño de las repoblaciones forestales}

\subsection{Nivel admisible de fallos $(A L F)$}

El éxito inicial de las plantaciones se mide tradicionalmente en términos de supervivencia de los brinzales (Maestre y Cortina, 2004; Vallejo et al., 2012) en una proporción suficiente para alcanzar una densidad objetivo. El estudio de la densidad objetivo ha recibido atención desde muy diferentes puntos de vista: i) conseguir la persistencia de la masa (Montalvo et al., 1997), ii) satisfacer la prestación de servicios ambientales (Guo et al., 2000; Guo et al., 2001), iii) maximizar al valor comercial forestal futuro (Huang et al., 2005), iv) minimizar el coste de establecimiento vegetal en las restauraciones vegetales en minas para recuperar la garantía (Sullivan y Amacher, 2013), o desde una visión más amplia, v) asegurar el cumplimiento de los objetivos y condicionantes de la repoblación (Serrada et al., 2005). Sin embargo, el estudio y el marco teórico del porcentaje admisible de planta perdida $(A L F)$ no se ha desarrollado en profundidad (Suding, 2011) por lo que sólo se dispone de algunas recomendaciones prácticas y otras de carácter normativo.

En la plantación de brinzales, el parámetro $A L F$ es el porcentaje admisible de planta perdida que es función de la densidad real obtenida en relación con la densidad ideal (Serrada et al., 2005); por lo tanto, a ALF se le puede considerar un indicador de la desviación admisible sobre la densidad óptima de plantación. ALF se ha empleado como un estándar técnico utilizado para evaluar el éxito de la plantación o el cumplimiento de normas de ejecución del proyecto de plantación (Sullivan y Amacher, 2013).

Serrada (2000) establece unos valores orientativos generales del ALF en función de clases de densidad de plantación, si bien, recomienda que los criterios que deben fijar el valor concreto del $A L F$ para cada caso sean función del objetivo de la repoblación y las posibles desviaciones admisibles, entre la densidad inicial de plantación y la que finalmente se ha logrado. Este autor también contempla que se pueda fijar un ALF para 
cada especie en el supuesto de repoblaciones pluriespecíficas. A partir de los valores discretos, indicados por el citado autor, es posible ajustar a una función exponencial: $A L F=0.0308 \cdot e^{7 \cdot 10^{-4} \cdot \rho}$ que define el valor del $A L F$ (t.p.u.) para densidades de repoblación entre 400 y 2.500 plantas/ha, donde $\rho$ es la densidad inicial de plantación (número de plantas por hectárea).

Esta relación pone de manifiesto la estrategia clásica seguida en el diseño de repoblaciones: densidades de plantación altas permiten ALF elevados. Esta forma de proceder, aunque efectiva a la hora de asegurar una alta densidad, es muchas veces inadecuada desde el punto de vista económico (costosos clareos y claras), e incluso errónea por contraproducente en entornos áridos y semiáridos (escasez hídrica para la densa vegetación implantada que termina no sobreviviendo). Además, en situaciones de escasez de recursos (agua, suelo, nutrientes) un incremento del número de individuos puede comprometer seriamente la supervivencia de la masa en su madurez (Mongil y Martínez de Azagra, 2006; Sprintsin et al., 2009). Así mismo, hay que tener presente que las marras del año se suelen concentrar, siendo su distribución espacial muy heterogénea y conduciendo a calveros indeseables, contrarios al objetivo de la restauración forestal.

Los ALF estrictos también han recibido críticas. Los estudios de Sullivan y Armecher (2013) señalan que ALF bajos pueden provocar una menor superficie restaurada en entorno degradado por la minería, debido al efecto disuasorio que tienen para los operadores de estas actividades, los costes esperados de rehabilitación.

La perspectiva normativa ofrece valores de referencia $A L F$ que deben cumplirse. En este sentido, en España, el desarrollo del programa de forestación de tierras agrarias de la Unión Europea establece un $A L F$ comprendido entre el 5\% y el 30\%, según comunidades autónomas, en función del marco de plantación, la especie, la estación y el tiempo transcurrido desde la plantación (Sequeda, 2017). En Turquía los valores de ALF son hoy en día del 40\%(Çalişkan y Boydak, 2017), y del 15\% en los programas de reforestación del suroeste de China (Trac et al., 2007).

La selvicultura urbana y periurbana también ofrece valores de referencia de $A L F$. A partir del análisis del mercado inmobiliario, diversos estudios (p. ej. Donovan y Butry, 2010; Pandit et al., 2013) han evaluado que la presencia de árboles urbanos, en concreto la fracción de cabida cubierta y la distancia a ellos, es la responsable del 0,75 al 4,21\%, según la ciudad, del precio de venta de las viviendas. Otros trabajos (Sander et al., 2010; Saphores y Li, 2012) calculan la elasticidad-precio de la demanda, obteniendo en espacios verdes abiertos y públicos (Brander y Coetse, 2011) efectos similares. Un último grupo de estudios (Widney et al., 2016) hallan el beneficio anual por árbol urbano, en el rango de 8,91 a 15,70 \$2016 para varias ciudades en Estados Unidos. A partir de esos datos y de la entrada en producción, $e=10$ años, Widney et al. (2016) plantean un modelo para determinar el valor de $A L F$, que estiman del $7 \%$ en su caso de estudio. Como consecuencia de él, concluyen la necesidad de realizar actuaciones tempranas para garantizar al menos ese nivel de supervivencia en los árboles que forman parte de la infraestructura verde urbana. 
La situación más extrema la proporcionan las plantaciones de árboles o arbustos en pantallas cortavientos (Ritchie, 1988; Sheikh 1988), amortiguadoras de ruidos (Fang y Lin, 2003; Van Renterghem 2014) o de reducción de la contaminación del aire (Abhijith y Gokhale, 2015; Abhijith et al., 2017). El fin de la selvicultura de estas barreras condiciona habitualmente que el nivel admisible de marras sea nulo para conseguir los fines de la plantación $(A L F=0)$.

Las orientaciones revisadas muestran que la cuestión sobre $A L F$ sigue abierta y requiere de mayor estudio: ¿Cuál es el porcentaje de marras admisible para que la plantación cumpla con los criterios que han servido para fijar la densidad de plantación?

\subsection{Número de años en que la producción se acelera debido a la irrigación $(\varepsilon)$}

Los resultados de ensayos experimentales muestran que algunos cuidados culturales en el establecimiento de los brinzales aumentan el crecimiento de las plantas como el acolchado (Dostálek et al., 2007) o el riego (Tabari y Ali-Shirzad, 2012). El modelo contempla la posibilidad de incluir el número de años que se adelanta la producción de la masa $(\varepsilon)$ para estimar el adelanto de rentas producido por la acción del riego. Para su estimación se puede acudir a los valores obtenidos de ensayos experimentales, en los que se compara durante una serie de años $\left(N_{\text {trial }}\right)$, algún indicador de crecimiento $\left(Y_{\text {treatment }}\right)$ en parcelas con tratamiento cultural, con respecto al obtenido en otras parcelas de control $\left(Y_{0}\right)$. Los estudios plantean distintos indicadores para evaluar el crecimiento de las plantas como son el diámetro, la altura o la biomasa, a veces, referidos a la parte aérea, otras a la subterránea, y en algunos estudios, a la total.

A partir del valor de estos indicadores se propone una primera aproximación al valor de $\varepsilon$ mediante la siguiente ecuación:

$$
\varepsilon=\frac{N_{\text {trial }}}{Y_{o}} \cdot\left(Y_{\text {treatment }}-Y_{o}\right)
$$

A modo de caso de estudio se utilizan los datos de ensayos experimentales publicados para mostrar el uso de la ecuación 1. En experimentos de campo mediante riego a una reforestación con Quercus ilex L. por aspersión con dosis de 0,5 ETP, Rey (1998) detecta que el aporte de agua del primer año favorece la supervivencia de los brinzales, y los practicados en el segundo y tercer año, el crecimiento de las plantas. A partir de los datos de este ensayo y utilizando la ecuación 1 para el indicador de biomasa se obtiene un valor de $\varepsilon=3,45$ años; con los datos de Baeza et al. (1991) para la misma especie e indicador de altura, se obtiene un $\varepsilon=3,84$ años.

Estos valores deben usarse con prudencia en el modelo puesto que aún es un debate abierto, si la ventaja proporcionada por el riego se mantiene en el tiempo (Khanzima et al., 2008) o desaparece a largo plazo, una vez que cesa el tratamiento (Rey y Camacho, 2004). Además, ensayos experimentales evidencian que la influencia del tratamiento puede variar según la especie, la dosis de agua aplicada y el indicador de crecimiento considerados (Kowsar et al., 1978). Análoga consideración puede hacerse para el caso de aporte suplementario de agua logrado por la cosecha de agua obtenida 
por el manejo de la escorrentía superficial mediante técnicas de preparación del terreno. Los datos experimentales evidencian como los valores de $\varepsilon$ varían por especie e indicador de crecimiento (Figura 1) en el periodo de ensayo.

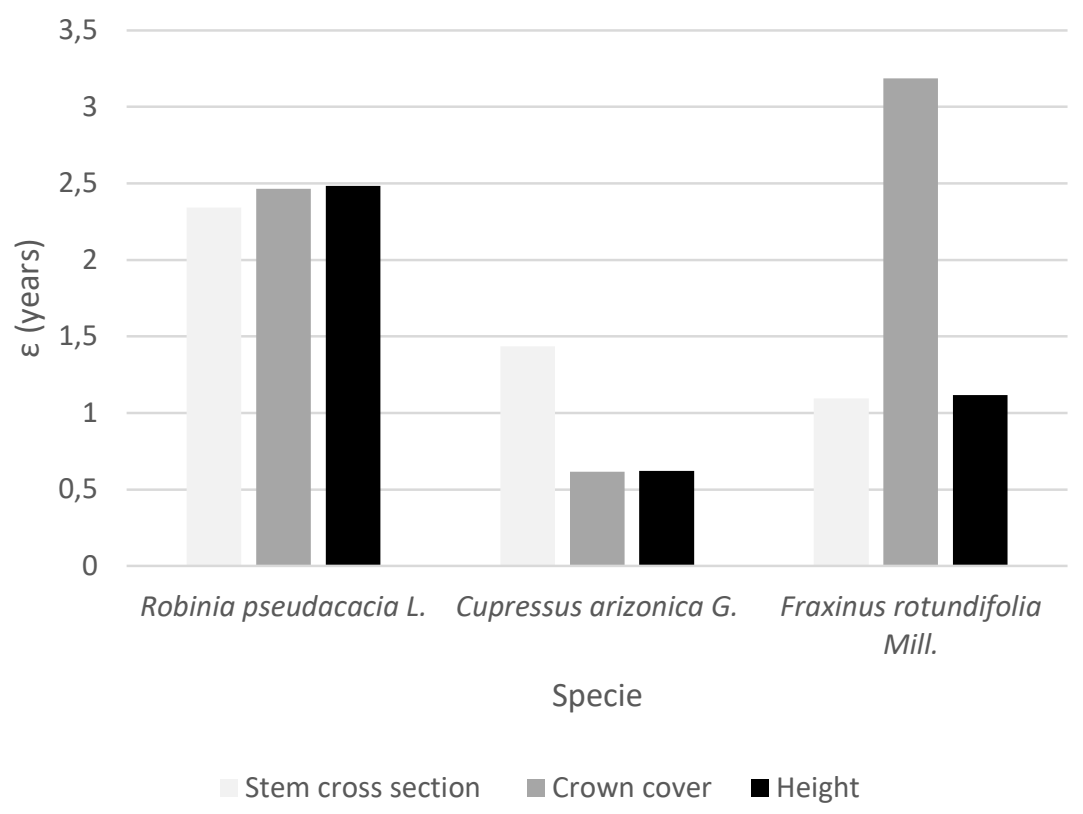

Figura 1. Variación de $\varepsilon$ por especie a partir de datos de ensayos experimentales de Kowser (1978)

\subsection{Marras esperadas $\left(\mathrm{M}_{\mathrm{R}}\right)$}

Las marras esperadas en la repoblación $\left(M_{R}\right)$ admite ser desglosada en tantos sumandos como causas distintas de la mortandad puedan concebirse (ecuación 2). Con el fin de resaltar la importancia que tiene el agua en zona árida, se agrupan las marras en dos términos: las debidas al estrés hídrico $(\psi)$ y las debidas a otros factores ajenos a la falta de agua $(\mu)$ (preparación del suelo, calidad de planta, estrés de plantación, herbivoría, estrés térmico, competencia, etc.), por lo tanto:

$$
M_{R}=\psi+\mu[2]
$$

Donde $M_{\mathrm{R}}, \psi$ у $\mu$ representan los valores medios de las tres variables.

La aplicación de micro-riegos en una repoblación tiene como finalidad minimizar el valor de $\psi$, hasta hacerlo nulo, por lo que las marras de la repoblación forestal serán debidas casi exclusivamente a factores no hídricos. Analíticamente estaremos ante el caso: $M_{R}=\mu$.

Para acotar esta incertidumbre la literatura sobre las marras en una repoblación forestal $\left(M_{R}\right)$ ha intentado identificar las causas posibles (Tabla 1). 
Tabla 1. Posibles causas de las marras en una repoblación forestal

\begin{tabular}{lc}
\hline \multicolumn{1}{c}{ Causa } & variable \\
\hline $\begin{array}{l}\text { Estrés hídrico: falta de agua, sequía extrema (muy mal año } \\
\text { meteorológico; escasas lluvias y cosechas de agua) }\end{array}$ & $\psi$ \\
$\begin{array}{l}\text { Errónea elección de especies y/o ecotipos: procedencias } \\
\text { equivocadas para la estación forestal }\end{array}$ & $\mu_{1}$ \\
$\begin{array}{l}\text { Mala calidad de planta: poco cepellón, plantas sin endurecer, mal } \\
\text { nutridas, sin micorrizar, enfermas, etc. }\end{array}$ & $\mu_{2}$ \\
$\begin{array}{l}\text { Incorrecta preparación del suelo: desbroce escaso, poco volumen } \\
\text { de suelo removido, mal tempero al realizar la labor, alcorque } \\
\text { pequeño, área de impluvio insuficiente, etc. }\end{array}$ & $\mu_{3}$ \\
$\begin{array}{l}\text { Daños mecánicos: por golpes, por eliminación de parte de la } \\
\text { planta, por aviveramiento descuidado, por plantación defectuosa }\end{array}$ & $\mu_{4}$ \\
Herbivoría (ramoneo) & $\mu_{5}$ \\
$\begin{array}{l}\text { Temperaturas extremas (altas o bajas) en el suelo y/o en el aire } \\
\text { Exceso de insolación (en especies de sombra, especies } \\
\text { umbrófilas) }\end{array}$ & $\mu_{6}$ \\
$\begin{array}{l}\text { pH muy desajustado; algunos elementos pueden resultar tóxicos } \\
\text { (caso del aluminio, del boro, o del cobre) } \\
\text { Déficit (en muy contadas ocasiones: exceso) de nutrientes }\end{array}$ & $\mu_{7}$ \\
$\begin{array}{l}\text { Falta de oxígeno en el suelo por encharcamientos prolongados } \\
\text { (situación improbable en zona árida) }\end{array}$ & $\mu_{8}$ \\
\hline
\end{tabular}

Si se tienen en cuenta en cuenta todos los factores que componen $\mu$, se puede acotar su valor máximo para una plantación y estación concretas, $\mu_{\mathrm{M} A X}=\max \left(\mu_{i}\right)$. El diseño y la ejecución en el terreno de la repoblación deben satisfacer que $\mu_{\mathrm{m} A \mathrm{X}}<A L F$.

El término $\psi$ resulta preponderante en zonas áridas, lugares en donde los riegos de brinzales encuentran su mayor aplicación. Si las marras se deben a otras causas ( $\psi$ nulo o muy pequeño y $\mu$ grande) serán otros los tratamientos culturales a prever y aplicar. Y en zonas en donde ambos términos tengan tendencia a ser grandes, habrá que idear tratamientos combinados: micro-riegos y uso de protectores y /o plantas nodrizas, enmiendas, fertilizantes, escardas, acolchados o herbicidas, entre otros.

Los valores promedio de la ecuación anterior pueden obtenerse de los informes y estadísticas locales sobre repoblaciones en estaciones similares donde se efectúe la repoblación.

Los estudios experimentales también facilitan valores empíricos específicos de una estación forestal y un periodo de años concreto. Para ello, el diseño experimental debe incluir parcelas de control y parcelas con tratamiento de riego. Rey (1998), después de tres años de ensayos, obtuvo una supervivencia en las parcelas de control del $53 \%$ $\left(M_{R}=0,47\right)$ y una supervivencia en las parcelas con tratamiento del 93\% $\left(M_{R}=0,07 \%\right)$. A partir de estos datos se pueden determinar los valores de $M_{R}, \psi, \mu$. En este caso. $M_{R}=$ $0,47 \psi=0,40 \mu=0,07$. Idéntico tratamiento puede hacerse con los datos proporcionados en el estudio de Sánchez et al. (2004) que ofrecen los siguientes valores experimentales 
para acebuche y pino carrasco en la Sierra de Alhamilla, en Almería (España).Las marras sin riego son: $M_{R}=0,97$ mientras que con riego los valores son menores: $M_{R}=0,06(=\mu)$. La diferencia de estas cifras permite deducir que el valor de las marras por estrés hídrico es $\psi=0,91$.

Aunque el modelo MThreshold ha previsto inicialmente la utilización del promedio de $M_{R}$, estudios regionales que vinculen variables predictoras relacionadas con la geografía, edafología y climatología permiten obtener valores probabilísticos de $M_{R}$ a partir de registros históricos. Como ejemplos de trabajo que consideran la variable $M_{R}$, aleatoria tenemos los ensayos realizados por Alloza y Vallejo (1999) en la Comunidad Valencia (España). Estos autores cuantificaron que al menos un $20 \%$ de los años registran periodos secos superiores a los 100 días de duración, dando lugar a porcentajes de marras superiores al 50\% en las especies de Quercus ilex $\left(\mathrm{r}^{2}=0,76\right)$, Quercus coccifera $\left(\mathrm{r}^{2}=0,80\right)$ y Pinus halepensis, $\left(\mathrm{r}^{2}=0,59\right)$ utilizando modelos lineales y como única variable predictora la duración de la sequía.

\section{Umbrales de decisión en cada grupo de aptitud al riego}

El análisis de incertidumbre (UA) cuantifica la incertidumbre en la variable de salida del modelo, mientras que el análisis de sensibilidad estudia la contribución de las variables de entrada y sus interacciones a los resultados del modelo (Saisana et al., 2005). El análisis de incertidumbre responde a cuestiones de diseño (Burhenne et al., 2013). Un ejemplo de una cuestión de este tipo sería ¿es posible que el umbral de marras sea del $30 \%$ ? Con el UA es posible responder a estas preguntas con probabilidades; siguiendo el ejemplo anterior, una respuesta posible sería que existe un $20 \%$ de probabilidad de que el diseño de la plantación y del sistema de riego considerado, produzcan un umbral de marras inferior o igual al 30\%. Los valores de probabilidad se obtienen de una función de distribución empírica ajustada a una serie de datos obtenidos mediante una simulación de Montecarlo.

El análisis de la incertidumbre planteado en este modelo tiene los siguientes objetivos: $i$ ) hallar la probabilidad actual de aplicación del micro-riego para todo el rango de variables de entrada considerado, ii) comprobar la representatividad de los grupos de aptitud para el micro-riego, iii) determinar las decisiones de regar, reponer marras, o realizar los cálculos del modelo por grupo de aptitud al riego.

El análisis de sensibilidad global y de incertidumbre de modelos deterministas utiliza habitualmente el marco probabilístico general basado en la simulación de Montecarlo (Baroni y Tarantola, 2014).

El UA necesario para conseguir estos fines es exploratorio (Helton, 1993), por lo que las distribuciones elegidas en la simulación de Montecarlo describen el rango más habitual de las variables de entrada en los diseños de plantación y sistemas de riego (Tabla 5). La simulación de Montecarlo se ha obtenido mediante el programa SimLab (Joint Research Centre of the European Commission. Released 2008. SimLab, Version 2.2.). Con el fin de asignar cada caso de la simulación un grupo de aptitud al micro-riego, 
se ha aplicado el método de clasificación de las K-medias, mediante el programa SPSS (IBM Corp. Released 2011. IBM SPSS Statistics for Windows, Version 20.0. Armonk, NY: IBM Corp.). A partir de esta asignación se han calculado las funciones de distribución empírica acumulada tanto para el total de la simulación de Montecarlo, como para los casos de la simulación agrupados según su aptitud al riego.

\subsection{Convergencia de la simulación de Montecarlo}

Para aplicar la simulación de Montecarlo es necesario comprobar que el número de realizaciones del modelo (Nmodel) sea superior al número mínimo de realizaciones recomendado (Nmin). Esta regla es relevante cuando existe correlación entre las variables de entrada. Un valor tentativo inicial de Nmin se obtiene mediante la siguiente expresión: $N \min =N S \cdot(2 \cdot I F+2)$, donde $N S$ es el número de muestras y $I F$ es el número de variables de entrada (Kucherenko et al., 2012). El valor de NS se estima mediante el criterio de Nyquist, $N S=1+4 \cdot I N^{2}(1+(I F-2) \Delta)$, con valores habituales de los parámetros factor de interferencia: $I N=4$ y ancho de paso de frecuencia $\Delta=2$ (Henkel et al., 2012). El valor de NS es una aproximación al tamaño de la muestra mínimo necesario, Nmin. La causa de esta regla se debe a que la tasa de convergencia de las sucesivas realizaciones es función de la estructura del modelo, del número de variables analizadas y de la técnica de muestreo empleada. Esta dependencia obliga a confirmar, mediante gráficos de convergencia, que se ha logrado la estabilidad de los resultados mediante la simulación de Montecarlo concreta que se está realizando (Burhenne et al., 2013).

La figura 2 representa la evolución de la convergencia de la estimación de la media y la varianza de $M$ para todos los grupos. Con $N$ model $=57.345$ realizaciones se cumple la regla para aplicar Montecarlo, que en este caso presenta valores de Nmin = 43.036, con $I F=13$ y NS=1.537.
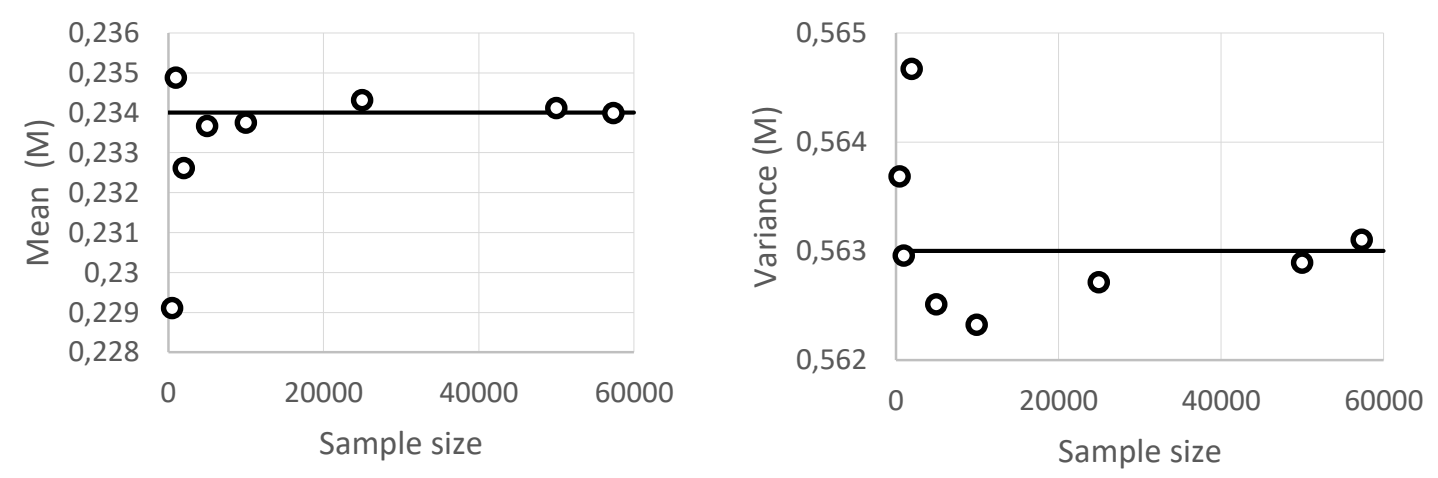

a) Estimación del promedio de $M$

b) Estimación de la varianza de $M$

Figura 2. Convergencia de la simulación de Montecarlo para el modelo MThrehold 


\subsection{Umbrales de decisión por grupo de aptitud según la simulación de Montecarlo}

El resultado del UA exploratorio realizado cuantifica la probabilidad de aplicación actual de la tecnología del micro-riego que existe hoy en día. La función de distribución empírica acumulada global para todos los diseños tiene un valor medio de $M=0,563$ con una $\sigma=0,234$ (Figura 3).

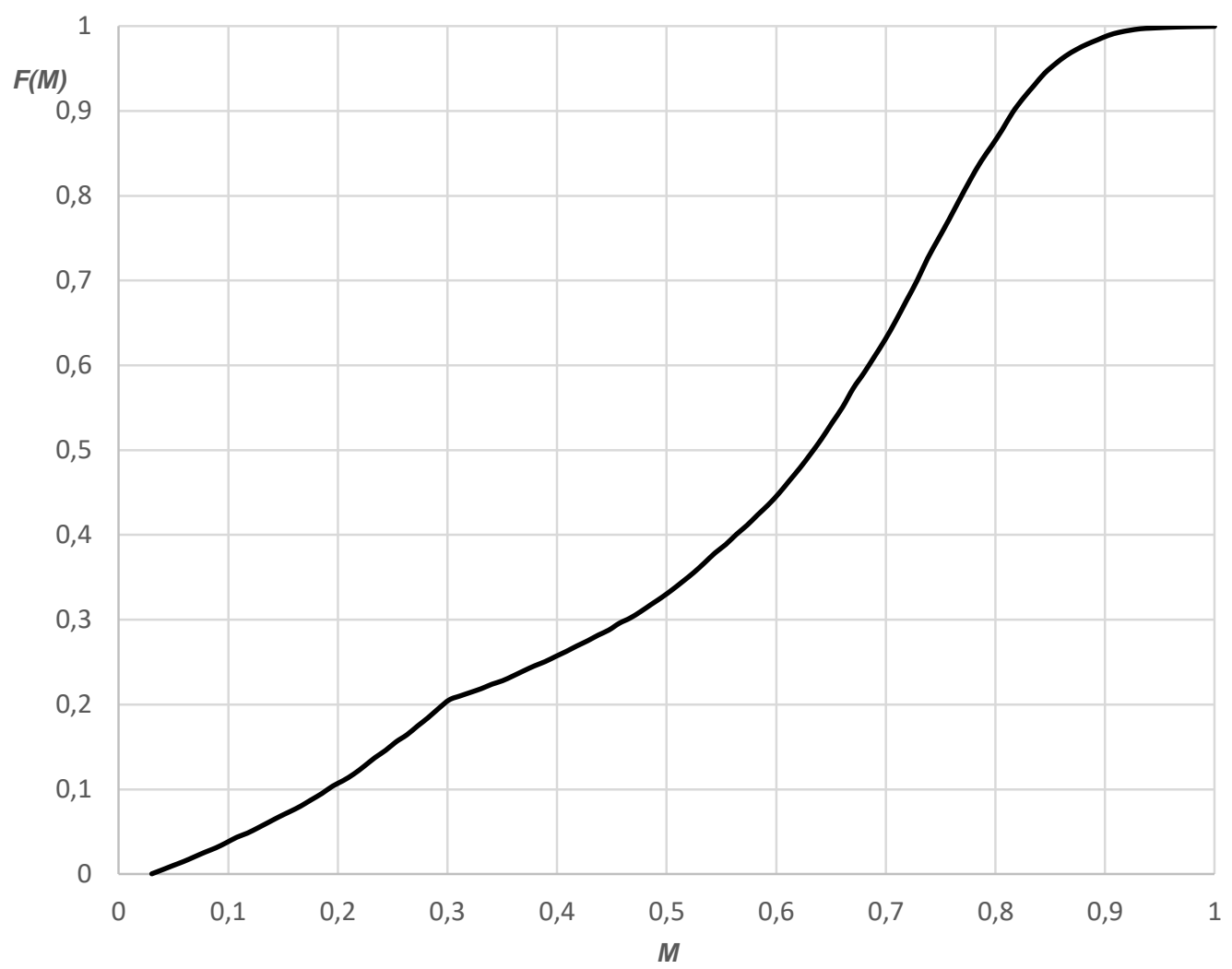

Figura 3. Función de distribución acumulada empírica de $M$

El análisis de incertidumbre de la tecnología ofrece un valor promedio de $M$ alto que viene a justificar la percepción que tienen los gestores: «El riego está reservado a situaciones donde las marras esperadas $M_{R}$ son cuantiosas». Además, el UA muestra que sólo hay un $20 \%$ de probabilidad de obtener un valor de $M$ inferior al $30 \%$, valor que está próximo a la tolerancia habitual aceptada normativamente para reponer marras, lo que explica que hasta la fecha no se haya popularizado la técnica del riego cuando se considera de forma global la plantación de brinzales.

Sin embargo, la pendiente de $F(M)$ muestra una variación lenta y gradual de la incertidumbre (Figura 3). Esta varianza indica que existen diseños de plantación de brinzales con umbrales de marras comprendidos en todo el rango de valores posibles de M. Por lo tanto, para discernir sobre la potencialidad y aplicación plausible de la tecnología se deben encontrar grupos según su aptitud al micro-riego. 
No es posible recurrir a las clasificaciones habituales utilizadas en la descripción de las plantaciones de brinzales (FAO, 2005) para definir los grupos de aptitud al riego, a pesar de que estas clasificaciones son la base de los sistemas estadísticos nacionales e internacionales de las plantaciones. El motivo es que en cada una de estas clases coexisten varias aptitudes al riego. Por esta razón se han definido tipologías funcionales (Batra y Pirad, 2015) que describen la aptitud al riego en función del valor de $M$ y ALF.

Al considerar la agrupación de las simulaciones por su aptitud al riego se observa (Figura 4) un comportamiento muy distinto de $F(M)$. Las funciones de distribución empírica acumulada $F(M)$ de los grupos, están separadas entre sí, motivo por el que los grupos de aptitud identificados son adecuados para describir el comportamiento de $M$ en cada tipo de diseño (Figura 4).

La incertidumbre en los resultados posibles de $M$ se reduce en rangos muy estrechos comprendidos entre los extremos, que se denominan $M_{M I N}$ y $M_{M A X}$, donde $M_{M I N}$ se define como el valor de $M$ en el que $F(M)=0$ y donde $M_{M A X}$, se define como el valor de $M$ donde $F(M)=1$.

Los rangos definidos por Mmin y Mmax indican el conjunto de fronteras que determinan la potencialidad actual de aplicación del micro-riego en cada grupo de aptitud (Figura 5). MMIN indica que no existe ningún diseño de repoblación y sistema de riego en el grupo que estemos considerando, que tenga una cuantía de $M$ inferior al valor señalado por $M_{M I N}$, por lo que si se cumple la condición de que $M_{R}<M_{M I N}$, la reposición de planta es la técnica elegida por el modelo. En el lado opuesto, cualquier diseño que se plantee en ese grupo, no superará $M_{M A X}$, motivo por el que si $M_{R}>M_{M A X}$ la alternativa elegida es el micro-riego. Cuando $M_{R}$ está comprendido dentro del rango ( $\left.M_{M I N}, M_{M A X}\right)$ la elección de la alternativa del riego está condicionada por la incertidumbre de las condiciones propias del diseño de la plantación y del sistema de riego consideradas, lo cual exige la utilización del modelo para determinar la alternativa más ventajosa económicamente.

Los casos de estudio considerados son representativos ya que se encuentran dentro del rango $M_{M I N}, M_{M A X}$ de cada grupo. El UA ha permitido verificar la adecuada construcción de los grupos para describir la variabilidad de $M$ y la relevancia de los casos de estudio considerados. 


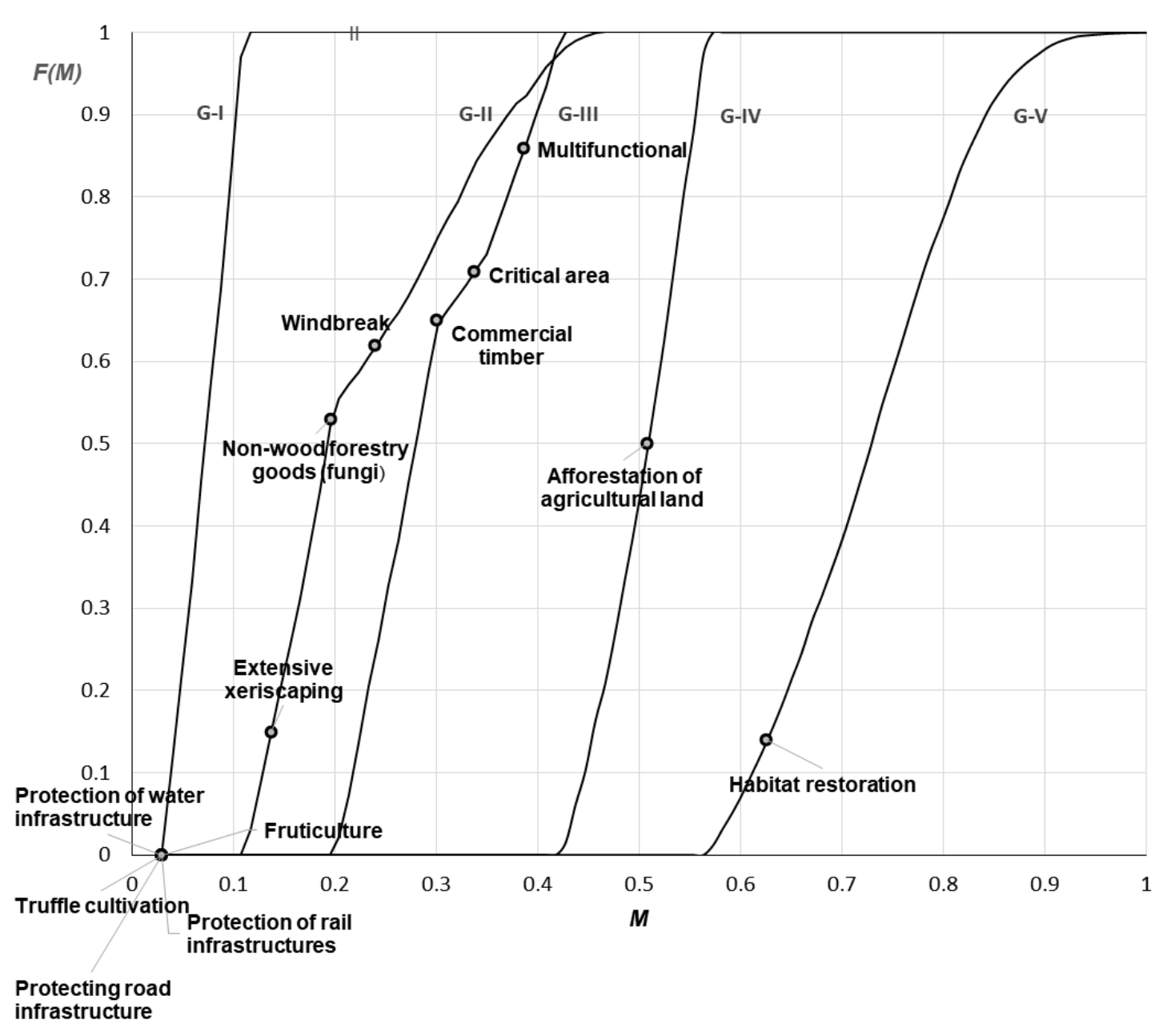

Figura 4. Función de distribución acumulada empírica de M por grupo de aptitud

La lectura de la figura 5 permite discriminar la alternativa más adecuada en cada grupo. En el grupo I (G-I) la decisión más probable es el riego, mientras que en el grupo $\mathrm{V}(\mathrm{G}-\mathrm{V})$ es la reposición. Este resultado coincide con las recomendaciones efectuadas en la literatura sobre la aplicación de cuidados culturales en las plantaciones de brinzales.

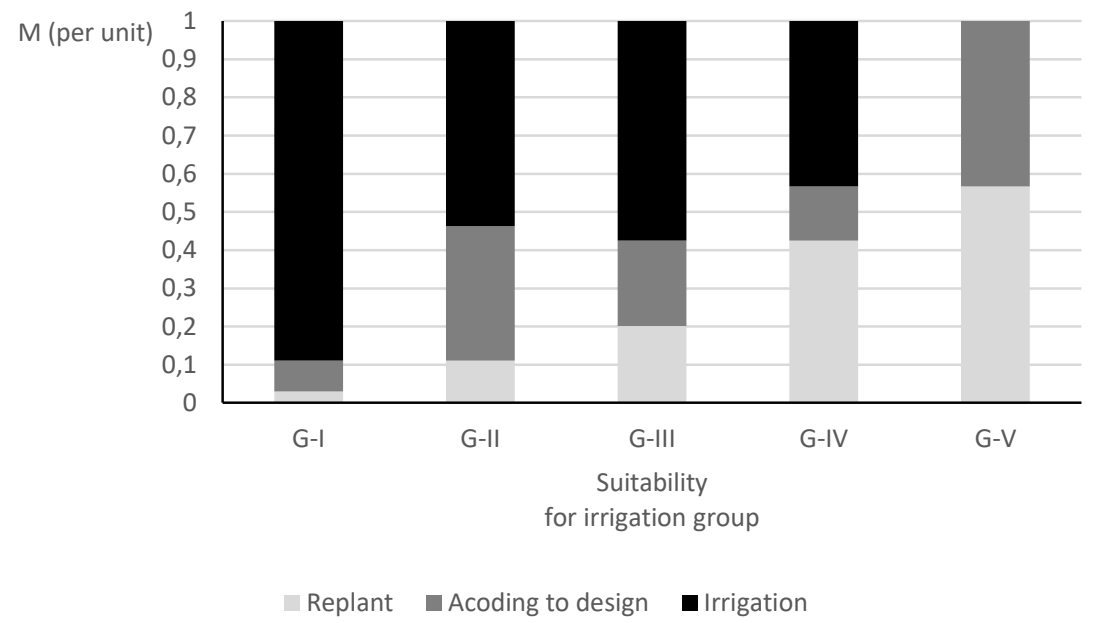

Figura 5. Decisiones del modelo por grupos de aptitud al micro-riego 
$\mathrm{El}$ análisis de incertidumbre de los grupos de aptitud al riego proporciona una visión global de los umbrales de aplicación de la tecnología del riego en cada tipo de plantación. Este dato ofrece una orientación sobre qué alternativa es más interesante en cada grupo de diseño. Esta aproximación, aunque práctica para obtener una perspectiva amplia de la selvicultura del riego de establecimiento, no puede sustituir a la utilización del modelo con los datos concretos del proyecto para elegir entre la alternativa del riego o la de reposición de planta.

\section{Hipótesis sobre las causas de las marras a través de los valores del modelo}

El patrón espacial de las marras puede ayudar a distinguir áreas donde estas se han producido de manera aleatoria de aquellas otras donde existe una agrupación de las marras de la repoblación, proporcionando información valiosa sobre los posibles factores causales y contribuyendo a generar hipótesis (Maestre et al., 2003). El análisis de los patrones espaciales no permite determinar por sí mismo qué proceso está originando la distribución en el espacio de la mortalidad de las plantas, debido a que el mismo patrón empírico puede ser asignado a causas distintas (Shipley y Keddy, 1987).

El modelo MThreshold complementa los resultados anteriores y permite plantear hipótesis concretas sobre el origen de las marras, de acuerdo con el número de años que se necesita realizar la reposición de planta $(N)$ y el promedio de marras en esos años $(M)$ (Tabla 2). Ambos datos se pueden obtener de manera sencilla por parte de los gestores a partir de la documentación de seguimiento de las repoblaciones forestales.

Tabla 2. Hipótesis de inferencia de la causa de la mortalidad a partir de los resultados del modelo MThreshold

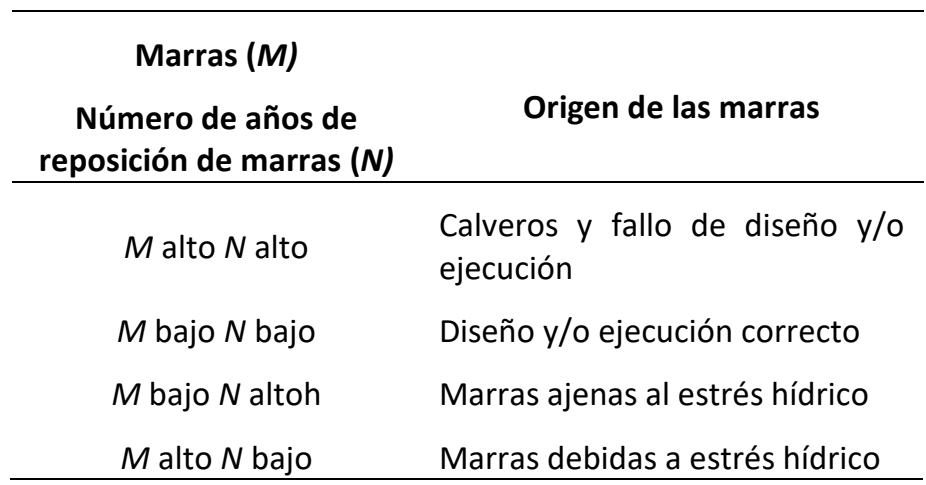

\section{Bibliografía}

Abhijith KV, Gokhale S (2015) Passive control potentials of trees and on-street parked cars in reduction of air pollution exposure in urban street canyons. Environmental Pollution 204:99-108. doi: 10.1016/j.envpol.2015.04.013

Abhijith KV, Kumar P, Gallagher J, McNabola A, Baldauf R, Pilla F, Broderick B, Di Sabatino S, Pulvirenti B (2017) Air pollution abatement performances of green infrastructure in open road and built-up street canyon environments - A review. Atmospheric Environment 162:71-86. doi:10.1016/j.atmosenv.2017.05.014

Alloza JA, Vallejo VR (1999) Relación entre las características meteorológicas del año de plantación y los resultados de las repoblaciones. Ecología (13):173-187 
Baeza M, Pastor A, Martín J, Ibáñez M (1991) Evolución de la respuesta en repoblaciones forestales de Pinus halepensis, Tetraclinis articulata, Quercus ilex y Ceratonia siliqua en la provincia de Alicante: crecimiento en altura. Studia Oecologica 8:195-202

Baroni G, Tarantola S (2014) A General Probabilistic Framework for uncertainty and global sensitivity analysis of deterministic models: A hydrological case study. Environmental Modelling \& Software 51:26-34. doi:10.1016/j.envsoft.2013.09.022

Batra P, Pirard R (2015) Is a typology for planted forests feasible, or even relevant? Center for International Forestry Research (CIFOR), Bogor, Indonesia. doi:10.17528/cifor/005608

Brander L M, Koetse MJ (2011) The value of urban open space: Meta-analyses of contingent valuation and hedonic pricing results. Journal of Environmental Management 92 (10):2763-2773

Burhenne S, Tsvetkova O, Jacob D, Henze GP, Wagner A (2013) Uncertainty quantification for combined building performance and cost-benefit analyses. Building and Environment 62:143-154

Çalişkan S, Boydak M (2017) Afforestation of arid and semiarid ecosystems in Turkey. Turkish Journal of Agriculture and Forestry 41 (5):317-329. doi:10.3906/tar-1702-39

Donovan GH, Butry DT (2010) Trees in the city: Valuing street trees in Portland, Oregon. Landscape and Urban Planning 94 (2):77-83

Dostálek J, Weber M, Matula S, Frantík T (2007) Forest stand restoration in the agricultural landscape: the effect of different methods of planting establishment. Ecological Engineering 29:77-86

Fang CF, Ling DL (2003) Investigation of the noise reduction provided by tree belts. Landscape and Urban Planning 63 (4):187-195

FAO (2005) Global Forest Resource Assessment 2005: Progress Toward Sustainable Forest Management. In: FAO Forestry Paper 147. Food and Agriculture Organization, Roma, Italy

Guo Z, Xiao X, Gan Y, Zheng Y (2001) Ecosystem functions, services and their values-a case study in Xingshan County of China. Ecological Economics 38:141-154

Guo Z, Xiao X, Li D (2000) An assessment of ecosystem services: water flow regulation and hydroelectric power production. Ecological Applications 10:925-936

Helton JC (1993) Uncertainty and sensitivity analysis techniques for use in performance assessment for radioactive waste disposal. Reliability Engineering and System Safety 42 (2):327-367. doi:10.1016/0951-8320(93)90097-I

Henkel T, Wilson H, Krug W (2012) Global sensitivity analysis of nonlinear mathematical models - An implementation of two complementing variance-based algorithms. Simulation Conference (WSC), Proceedings of the 2012 Winter. IEEE, pp. 1-12

Huang CH, Kronrad GD, Morton JD (2005) The financially optimal loblolly pine planting density and management regime for nonindustrial private forestland in East Texas. Southern Journal of Applied Forestry 29:16-21

Khamzina A, Lamers J, Vlek P (2008) Tree establishment under deficit irrigation on degraded agricultural land in the lower Amu Darya River region, Aral Sea Basin. Forest Ecology and Management 255:168178

Kowsar A, Mehdizadeh P, Vaziri E, Boersma L (1978) Water Harvesting for Afforestation: II. Survival and Growth of Trees1. Soil Science Society of America Journal 42:650-657

Kucherenko S, Tarantola S, Annoni P (2012) Estimation of global sensitivity indices for models with dependent variables. Computer Physics Communications 183:937-946

Maestre F, Cortina J, Bautista S, Bellot J, Vallejo VR (2003) Small scale environmental heterogeneity and spatiotemporal dynamics of seedling establishment in a semiarid degraded ecosystem. Ecosystems 6:630-643 
Maestre FT, Cortina J (2004) Are Pinus halepensis plantations useful as a restoration tool in semiarid Mediterranean areas? Forest Ecology and Management 198:303-3174

Mongil J, Martínez de Azagra A (2006) Diseño de repoblaciones forestales en zonas áridas: tamaño del microembalse y relación entre el área de impluvio y el área de recepción. Investigaciones geográficas 40:201-226

Montalvo AM, Williams SL, Rice KJ, Buchmann SL, Cory C, Handel SN, Nabhan GP, Primack R, Robichaux RH (1997) Restoration Biology: A Population Biology Perspective. Restoration Ecology 5:277-290

Pandit R, Polyakov M, Tapsuwan S, Moran T (2013) The effect of street trees on property value in Perth, Western Australia. Landscape and Urban Planning 110:134-142. doi:10.1016/j.landurbplan.2012.11.001

Rey JM (1998) Growth and survival in Quercus ilex L. seedlings after irrigation and artificial shading on Mediterranean set-aside agricultural land. Annals of Forest Science 55:801-807

Rey JM, Camacho A (2004) Performance of Quercus ilex saplings planted in abandoned Mediterranean cropland after long-term interruption of their management. Forest Ecology and Management 194:223-233

Ritchie KA (1988) Shelterbelt Plantings in Semi-arid Areas A2 - Brandle JR In: Hintz DL, Sturrock JW (eds) Windbreak Technology. Elsevier, Amsterdam, pp. 425-440

Saisana M, Saltelli A, Tarantola S (2005) Uncertainty and sensitivity analysis techniques as tools for the quality assessment of composite indicators. Journal of the Royal Statistical Society: Series A (Statistics in Society) 168:307-323

Sánchez J, Ortega R, Hervás M, Padilla F, Pugnaire F (2004) El microrriego, una técnica de restauración de la cubierta vegetal para ambientes semiáridos. Cuadernos de la Sociedad Española de Ciencias Forestales 17:109-112

Sander H, Polasky S, Haight RG (2010) The value of urban tree cover: A hedonic property price model in Ramsey and Dakota Counties, Minnesota, USA. Ecological Economics 69 (8):1646-1656. doi:10.1016/j.ecolecon.2010.03.011

Saphores JD, Li W (2012) Estimating the value of urban green areas: A hedonic pricing analysis of the single family housing market in Los Angeles, CA. Landscape and Urban Planning 104 (3):373-387

Serrada R (2000) Apuntes de Repoblaciones Forestales. Fundación Conde Valle de Salazar. Escuela Universitaria de Ingeniería Técnica Forestal. Madrid

Serrada R, Navarro RM, Pemán J (2005) La calidad de las repoblaciones forestales: una aproximación desde la selvicultura y la ecofisiología. Investigación Agraria: Sistemas y Recursos Forestales 14:462-481

Sheikh MI (1988) Planting and Establishment of Windbreaks in Arid Areas A2 - Brandle JR In: Hintz DL, Sturrock JW (eds), Windbreak Technology. Elsevier, Amsterdam, pp 405-423

Shipley B, Keddy P (1987) The individualistic and community-unit concepts as falsifiable hypotheses. Vegetatio 69:47-55

Sprintsin M, Karnieli A, Sprintsin S, Cohen S, Berliner P (2009) Relationships between stand density and canopy structure in a dryland forest as estimated by ground-based measurements and multi-spectral spaceborne images. Journal of Arid Environments 73:955-962

Sequeda MM (2017) Forestación de tierras agrarias en Extremadura. In: Sociedad Española de las Ciencias Forestales (ed), $7^{\mathfrak{o}}$ Congreso Forestal Español: la gestión del monte: servicios ambientales y bioeconomía, Plasencia, España

Suding KN (2011) Toward an era of restoration in ecology: successes and failures along the science-practice divide. Annual Review of Ecology, Evolution, and Systematics 42:465-487

Sullivan J, Amacher GS (2013) Optimal hardwood tree planting and forest reclamation policy on reclaimed surface mine lands in the Appalachian coal region. Resources Policy 38:1-7 
Tabari M, Ali Shirzad M (2012) Growth Characteristics of Rainfed/Irrigated Juniperus excelsa Planted in an Arid Area at North-Eastern Iran In: Lee TS (ed) Water Quality, Soil and Managing Irrigation of Crops. InTech, pp 161-168

Trac CJ, Harrell S, Hinckley TM, Henck AC (2007) Reforestation programs in Southwest China: reported success, observed failure, and the reasons why. Journal of Mountain Science 4 (4):275-292

Vallejo VR, Allen EB, Aronson J, Pausas JG, Cortina J, Gutiérrez JR (2012) Restoration of MediterraneanType Woodlands and Shrublands, Restoration Ecology. John Wiley and Sons, Ltd, pp 130-144

Van Renterghem T (2014) Guidelines for optimizing road traffic noise shielding by non-deep tree belts. Ecological Engineering 69:276-286. doi:10.1016/j.ecoleng.2014.04.029

Widney S, Fischer BC, Vogt J (2016) Tree mortality undercuts ability of tree-planting programs to provide benefits: results of a three-city study. Forests 7 (3):65. doi:10.3390/f7030065 


\section{Capítulo 6. Herramienta informática para la integración económica del riego de brinzales en el diseño de plantaciones}

En los últimos años el mercado oferta una amplia gama de tecnologías y patentes para realizar riegos de apoyo y de socorro con los que asegurar el establecimiento de los brinzales de repoblación, economizando, a la vez, la escasa agua disponible. El sobrecoste económico inicial que origina la aplicación de estas nuevas tecnologías puede verse compensado con la evitación de los costes de reposición de marras que suelen ser necesarios en muchas estaciones forestales (zonas áridas, orientaciones a solana, áreas críticas u otras). La decisión a adoptar en cada caso debe estar razonada, ajustándose a las características concretas de cada proyecto y tecnología de riego en estudio. Esta nota técnica presenta el software que se fundamenta en el modelo MThreshold que permite hallar el umbral de marras $M$ a partir del cual resulta más económico regar que reponer marras. El software ofrece total libertad al usuario para poder configurar todos los parámetros y variables, con el fin de poder ajustarlos a cada situación económica, repobladora y de riego que desee analizar. Esta aplicación informática va destinada a los repobladores forestales y a los fabricantes de sistemas de riego de brinzales. A los primeros les brinda la oportunidad de analizar la opción de incorporar el riego en sus plantaciones, ya desde la fase de proyecto, y a los segundos, les orienta sobre la política de precios a seguir para poder comercializar sus productos con éxito. 


\section{Introducción}

Los gestores y propietarios de bosques demandan software especializado en gestión forestal para elegir y planificar las actuaciones con mayor eficacia y rentabilidad (Hennessy y Lawlor, 2000) debido a que las decisiones sobre el diseño y manejo de las plantaciones forestales influyen en el rendimiento de la inversión (Catchpoole y Nester, 2004). El análisis de la rentabilidad de las operaciones selvícolas relacionadas con el establecimiento y mantenimiento de brinzales es especialmente relevante en las inversiones forestales. El motivo es que la economía puede limitar la aplicación de las medidas de apoyo a la supervivencia, por la elevada repercusión financiera que tienen al producirse en los primeros años del ciclo de vida de una plantación forestal (Mangaoang, 2002; Hepburn y Koundouri, 2007).

El riego de brinzales es una medida de apoyo a la supervivencia que resulta interesante (cuando no imprescindible) para asegurar el arraigo y primer crecimiento de una plantación forestal en tierras áridas (Bainbridge, 2002; Martínez de Azagra y Del Río, 2012; Del Río et al., 2013), ya que el estrés hídrico supone la principal causa de fracaso en las repoblaciones y plantaciones bajo climas áridos (Moles y Westoby, 2004). Los riegos de brinzales están además plenamente justificados en otros entornos climatológicamente menos severos, en los que el objetivo de la repoblación sea asegurar un porcentaje de marras mínimo, como ocurre en la protección de infraestructuras o en el control de procesos erosivos severos (Serrada et al., 2005) y también cabe concebir otras aplicaciones interesantes como la obtención de productos forestales con un alto valor económico, como es el caso de las setas (Oria de Rueda, 2007).

A pesar de que la utilización del tratamiento cultural pueda estar motivado técnicamente, su aplicación conlleva un considerable incremento de la inversión inicial. No es posible transferir a la práctica el avance tecnológico proporcionado por las nuevas técnicas de restauración sin la evaluación de su rentabilidad (Bautista y Alloza, 2009), motivo por el que su uso debe estar bien justificado desde el punto de vista financiero. Surge así un interrogante al que conviene dar respuesta: ¿Cuándo compite el riego de brinzales con ventaja respecto de la tradicional técnica de reposición de marras?

En este capítulo se presenta un software, basado en el modelo MThreshold (Del Río et al., 2018) que facilita la toma de decisiones respecto de si utilizar o no el riego de brinzales en el establecimiento de la masa.

\section{Base y modelo teórico}

Conocer el valor del umbral de marras $M$ asociado a unas características de diseño de una plantación supone para los forestales un dato relevante con el que poder decidir, con base económica, sobre la conveniencia (o no) de aplicar riegos a los brinzales introducidos. 
El software resuelve un sistema de dos inecuaciones diofánticas propuesto por Del Río et al. (2018), determinando el valor fronterizo o umbral $M$ a partir del cual resulta más rentable el riego que la reposición de planta.

Para obtener el valor del umbral $M$, el modelo plantea una ecuación económica [1] que establece la condición de que la alternativa del riego debe tener un balance de coste - beneficio favorable comparada con la alternativa tradicional de reposición de marras.

$$
C_{w a t}-B I_{P V} \leq C_{r e p}+L P_{P V}
$$

y una ecuación sobre la estrategia de reposición de planta [2] que obtiene el número de años necesario de reposición de marras para alcanzar la densidad objetivo en la plantación.

$$
N \geq \frac{\ln A L F}{\ln M} \quad[2]
$$

A partir de este resultado el programa aplica la siguiente regla de decisión: Si en el lugar de estudio, las marras esperadas en la plantación $\left(M_{R}\right)$ son superiores al mencionado umbral $M$, el riego será la alternativa técnica recomendable desde un punto de vista económico; en caso contrario, la opción aconsejable es la reposición de marras (Figura 1).

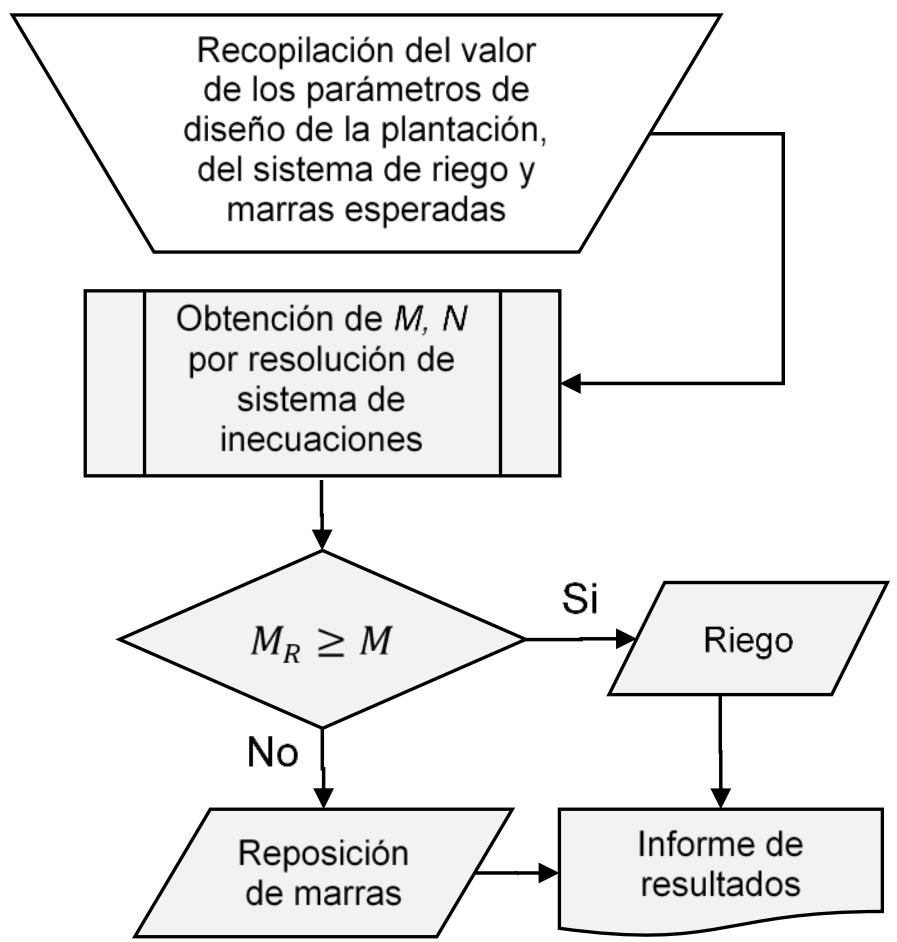

Figura 1. Diagrama de flujo del sistema de decisión

\section{Sectores interesados}

La identificación de los usuarios y sus requerimientos técnicos son condiciones críticas del diseño del software. El motivo es que, para cerrar la brecha observada en la 
trasferencia entre los modelos y sus usuarios finales, se deben considerar las expectativas de los destinatarios para los cuales se diseñó el modelo (Faias et al., 2012; Calama et al., 2017). Muys et al. (2010) profundizan en esta idea y señalan que el grado de aceptación de un modelo forestal depende de la capacidad que tenga la aplicación de incluir las necesidades y capacidad de los usuarios. En nuestro caso, los proyectistas, gestores y propietarios forestales (por un lado) y los fabricantes de sistemas de riego de brinzales (por otro) son los principales grupos interesados que se han identificado en el uso del modelo y en su software asociado MThreshold, junto con otros científicos y profesionales del sector ambiental.

Por esta razón el software se ha diseñado con una gran flexibilidad en la definición de los parámetros de entrada contemplados habitualmente en el diseño de una plantación. Esta característica permite aplicar el modelo a todos los escenarios de plantación posibles, sean cuales sean sus especies, material forestal de reproducción, preparación del terreno o, densidades, tolerancias y objetivos, entre otros. De igual manera se ha procedido con los sistemas de riego y las decisiones relativas a la irrigación. La variedad de usuarios finales también se ha contemplado en el tratamiento de las variables de salida que ofrece el programa. Esta es la razón por la cual los resultados están referidos a la superficie de actuación (generalmente la hectárea) o al número de brinzales implantados con éxito. Ambas perspectivas de análisis son interesantes y - en ciertos aspectos - complementarias.

Por otro lado, para los fabricantes de sistemas de riego MThresold ofrece una información estratégica con la que delimitar el campo real de aplicación de su tecnología, es decir, en qué lugares y con qué límites resulta competitivo su producto. En especial el coste del producto y el precio en el que resulta competitiva la comercialización de su tecnología en un área geográfica y en un tipo de plantación concretos.

\section{Componentes del programa}

\subsection{Entradas}

El programa admite dos modos de introducción de datos: mediante formulario para la resolución de un caso concreto, o mediante el procesamiento por lotes para el cálculo simultáneo de múltiples casos.

El formulario tiene cargados valores de referencia y listas desplegables para facilitar el primer uso del programa, aunque permite la configuración de todos los parámetros. Al modo de introducción por lotes se accede pulsando el botón (Batch).

Las entradas del programa son: las características de la plantación proyectada, del sistema de riego y el tipo de interés. Cada parámetro dispone de un botón de ayuda que explica su significado. También existe una validación de datos que evita la introducción de caracteres erróneos o valores fuera de rango. 


\subsubsection{Características de la plantación}

Como características, el software considera la densidad de plantación $(\rho)$ [número de plantas/unidad de superficie], el nivel admisible de fallos (ALF) [tanto por uno], los costes y los beneficios.

Los costes considerados son el coste de la planta a reponer $(C p)$ y el coste de las labores de reposición de marras $(\mathrm{Cm})$. Ambos dependen del número de marras anual (M). La primera versión de MThreshold maneja relaciones lineales de estas dos variables (con o sin término independiente) para cuantificar los costes individualizados.

- El coste de la planta a reponer $(C p)$ se obtiene mediante el precio unitario del brinzal o de las semillas a enterrar en cada punto (c) [unidad monetaria planta $^{-1}$ o unidad monetaria $\cdot \operatorname{semilla}^{-1}$.

- Para el coste de las labores de reposición de marras $(\mathrm{Cm})$ el software utiliza un modelo lineal con término independiente $(C m=a+b \cdot M)$ pues es el que subyace en los catálogos profesionales de precios unitarios de trabajos forestales en España. Pero el usuario puede remplazar este modelo lineal por cualquier otro que considere más ajustado a su proyecto.

Desde un enfoque forestal, el programa realiza la estimación de beneficios a partir de una renta media anual esperada $(R)$ [unidad monetaria/unidad de superficie], que considera los beneficios directos e indirectos de la plantación, y un lapso de tiempo medio de entrada en producción (e) [años]. A su vez, las marras (aun siendo repuestas) pueden menguar los beneficios, el lucro cesante $(L P)$ que también que también es considerado por el software. El programa permite resolver el problema mediante un modelo de costes evitados, para lo cual hay que trabajar con un valor nulo en la renta $R$ (Del Río et al., 2013).

La primera versión de MThreshold no contempla la posibilidad de poder introducir los beneficios anuales de cada una de las dos alternativas (con o sin riego), enfoque que es frecuente en arboricultura, no así en el sector forestal.

\subsubsection{Características del riego}

Los costes del riego se desglosan en el coste de adquisición e instalación del riego en el monte $(C d)$, y el coste de aplicación de los riegos $(C w)$. Ambos dependen de la densidad de plantación $(\rho)$.

- El coste de adquisición e instalación del sistema de riego $(C d)$ se calcula a partir de dos parámetros: el precio unitario del sistema de riego $(d)$ [en unidad monetaria.planta-1 ${ }^{-1}$, y un factor $(h)$ [adim.] que evalúa la facilidad o dificultad de instalación del sistema en el lugar a repoblar.

- El coste de la aplicación de los riegos (Cw) se estima a partir de los siguientes tres parámetros: la aportación hídrica anual suplementada mediante riego a cada brinzal $\left(N R_{j}\right)\left[\mathrm{L} \cdot\right.$ planta $\left.^{-1} \cdot \mathrm{año}^{-1}\right]$, el número de años en los que se realizan riegos $\left(n_{r i}\right)$ y el precio del agua de riego $(w)$ [unidad monetaria $\mathrm{L}^{-1}$ ] que, a su vez, depende de los gastos 
necesarios para la aplicación del agua (método de riego, coste de jornales, distancia a la fuente de agua, necesidad de bombeo, entre otros) y del precio unitario del agua [unidad monetaria $\cdot \mathrm{m}^{-3}$ ] (en el caso de que haya tarifación volumétrica para el agua de riego).

MThreshold contempla la posibilidad de que con el riego la entrada en producción se adelante unos años $(\varepsilon)$, generando un beneficio adelantado $(B I)$.

\subsubsection{Características financieras}

El tipo de interés aplicable al proyecto (i) [en tanto por uno] se utiliza para descontar al valor presente todos los costes y beneficios individuales considerados.

\subsection{Salidas}

La salida principal del programa es el umbral $M$, a saber: el tanto por uno de marras a partir del cual el riego compite con ventaja económica respecto de la clásica solución de reponer marras hasta conseguir la densidad de plantas objetivo. Este umbral se ha de comparar con las marras esperadas en la repoblación $\left(M_{R}\right)$.

Como salidas complementarias de interés para la toma de decisiones, el software ofrece los siguientes datos: el número de años en los que hay que reponer marras $(N)$ para satisfacer la tolerancia exigida, las densidades finales alcanzadas (por unidad de superficie) con cada alternativa, la composición de costes y de beneficios (por unidad de superficie y por planta conseguida con autonomía hídrica). El programa admite la salida impresa del formulario.

\subsection{Herramienta informática}

Hemos desarrollado el software como herramienta necesaria para para facilitar el uso del modelo. El software permite introducir datos de distintas formas de gestión tanto de la plantación como de la tecnología del riego.

MThreshold se ha desarrollado en Visual Basic y se ha integrado en una hoja de cálculo, por ser el sistema actual más popular entre los gestores forestales (Hennessy y Lawlor, 2000) e industriales. En este caso se ha implantado en Microsoft ${ }^{\circledR}$ Excel por estar en consonancia con las recomendaciones del modelo STAM (Renaud y Van Biljon, 2008) de tener presente el uso actual, la facilidad de aprendizaje y las condiciones facilitadores para lograr la aceptación tecnológica. La introducción y salida de datos se gestiona desde un único formulario que facilita la tarea de analizar de manera completa toda la información del modelo, como puede apreciarse en la figura 2. 


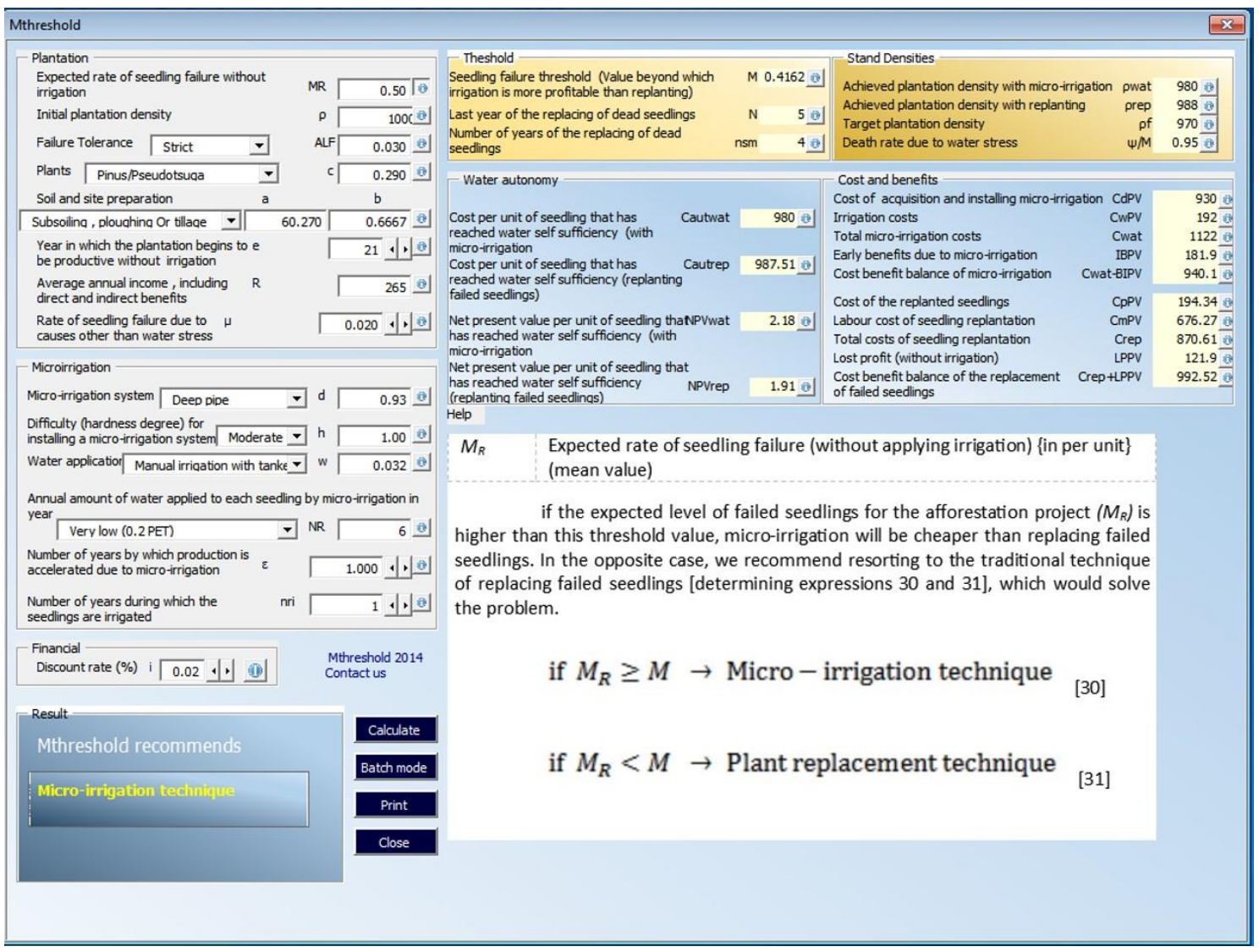

Figura 2. Aspecto visual del formulario de entrada/salida de datos de MThreshold versión 1

Una de las principales prestaciones de las hojas de cálculo es que permiten realizar simulaciones fácilmente con las que responder a cuestiones del tipo «what if»» variando los valores de las entradas del modelo (Harrinson, 2002) y permitiendo un procesamiento en lotes que también ha sido contemplado en el software.

\section{Propiedad del software}

El software MThreshold es un producto propiedad de la Universidad de Valladolid, adquirido a los autores mediante el programa de transferencia Prometeo 2016. Más información al respecto se encuentra disponible en el siguiente enlace:

http://wally.gti.tel.uva.es/CytUVA/proyecto.php?id=346C $<$ Consultado en línea 25/05/2018>

\section{Ejemplo de aplicación del programa}

\subsection{Datos de entrada}

Se plantea un caso real en una zona semiárida de Almería (Andalucía, España) fácilmente accesible y transitable. Se proyecta una repoblación protectora con una densidad de 1.000 plantas por hectárea, monoespecífica, de Pinus halepensis Mill., de 2 savias en contenedor y con preparación manual del terreno mediante el perfilado de microcuencas. Repoblaciones efectuadas en la misma zona presentan habitualmente una tasa de marras superior al 50\% $\left(M_{R} \geq 0,5\right)$. En esta situación se desea conocer a partir de 
qué umbral de marras $(M)$ resulta más económico instalar un sistema de micro-riego por tubos verticales y aplicación manual del riego durante los dos primeros años, mediante camión cisterna con dos operarios, en vez de tener que proceder a la reposición de marras, para cumplir el objetivo de la repoblación. El coste de la repoblación inicial es $1.482,00 € /$ ha $(1,48 € /$ planta). La bajísima dotación anual necesaria para evitar marras por estrés hídrico (6 L/planta/año) se satisface mediante dos micro-riegos de apoyo (de 3 L/planta) realizados durante el periodo seco, en julio y agosto (Sánchez et al., 2004). La tasa de marras por causas ajenas al estrés hídrico en la zona se estima en un $2 \%(\mu=0,02)$.

Se analizan dos situaciones de exigencia en la tolerancia de marras. El caso a) con un nivel admisible de fallos muy estricto del $3 \%(A L F=0,03)$ y el caso b) con un nivel admisible de fallos del $20 \%$, mucho más habitual en repoblaciones forestales tradicionales $(A L F=0,2)$.

Conforme a los datos de la repoblación (Tabla 1), los parámetros de entrada del modelo son: $\rho=1.000$ plantas/ha; $n_{r i}=2(\Delta n=1$; para anular las marras por estrés hídrico con más certeza); $\mu=0,02$ (como $\mu \leq A L F \Rightarrow$ no hay que reponer marras en la alternativa del micro-riego); $a_{j}=82,00 € /$ ha y $b_{j}=1,10 € /$ planta (microcuencas); $c_{j}=0,30 € /$ planta (Pinus halepensis Mill. en envase de 2 savias); $w_{j}=0,005 € / \mathrm{L}$ (riego individual); $N R_{j}=6 \mathrm{~L} /$ planta y año; $d=0,93 € /$ planta (tubos verticales sin dificultad de instalación); $e=21$ (repoblación protectora); $\varepsilon=2$ años (los micro-riegos anuales duplican el crecimiento de la planta, manteniéndose esta ventaja en el tiempo); $R=265,00 € /$ ha (renta media que incluye los beneficios productivos, ambientales y recreativos); $i=0,04$ tanto por uno (tipo de interés del 4\%, establecido normativamente en España para proyectos de financiación pública). 
Tabla 1. Costes y parámetros del caso de estudio

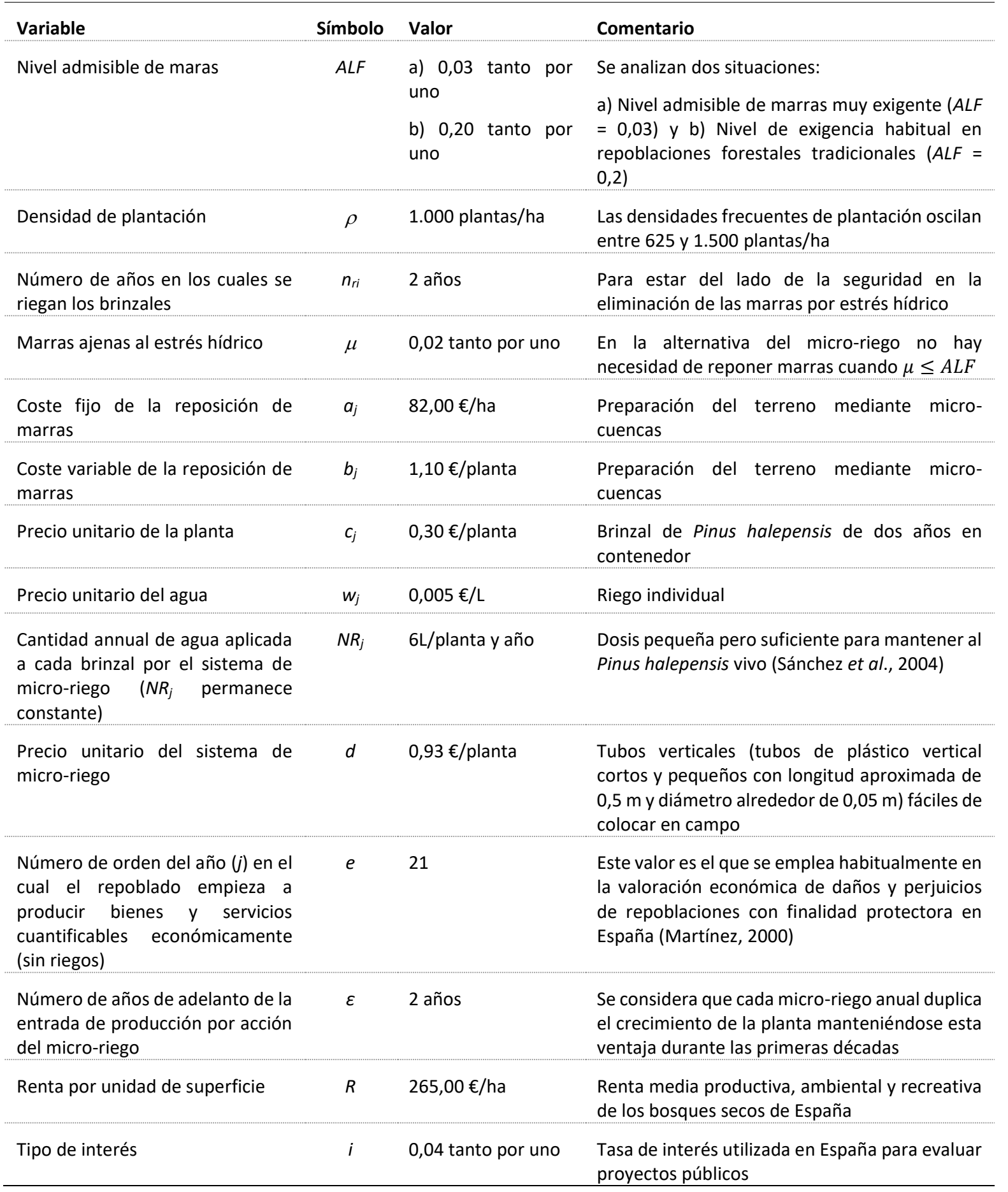

Fuentes: lista de precios de trabajos forestales (impuestos no incluidos). Año de referencia, 2013. Disponibles en:

http://www.tragsa.es/es/acerca-del-grupo/Paginas/tarifas-tragsa.aspx

http://www.basepaisajismo.com/

http://www.magrama.gob.es/es/biodiversidad/servicios/banco-datos-naturaleza/informacion-disponible/ifn3.aspx

\subsection{Resultados del programa}

En la tabla 2 se incluyen los resultados del modelo particularizado a estos dos casos de estudio. La resolución del sistema de dos ecuaciones [1 y 2] permite obtener el valor de $M$ : en el primer caso a) $M=0,3045$ (tanto por uno) y en el segundo caso b) $M=$ 
0,4454 (tanto por uno). En ambos se cumple la desigualdad $M_{R} \geq M$ [3] pues el valor de $M_{R}$ ( $\geq 0,5$ tanto por uno) es superior a los umbrales $M$ hallados, por lo que la técnica de micro-riego es la opción que se debe elegir, al ser más económica que la reposición de marras.

Tabla 2. Resumen de los resultados del caso de estudio para los niveles de tolerancia de fallo

\begin{tabular}{|c|c|c|c|c|}
\hline \multirow{2}{*}{$\begin{array}{l}\text { Variables } \\
\text { Nivel admissible de fallos }\end{array}$} & \multirow{2}{*}{$\begin{array}{c}\text { Unidad } \\
\text { tanto } \\
\text { por uno }\end{array}$} & \multirow{2}{*}{$\begin{array}{c}\text { Símbolo } \\
\text { ALF }\end{array}$} & \multicolumn{2}{|c|}{ Valor } \\
\hline & & & 0,03 & 0,2 \\
\hline $\begin{array}{l}\text { Umbral de marras (valores por debajo de los } \\
\text { cuales la irrigación es más beneficiosa que la } \\
\text { reposición) }\end{array}$ & $\begin{array}{l}\text { tanto } \\
\text { por uno }\end{array}$ & $M$ & 0,3045 & 0,4454 \\
\hline Último año de reposición de planta & año & $N$ & 3 & 2 \\
\hline $\begin{array}{l}\text { Número de años en los cuales se realiza la } \\
\text { reposición de planta }\end{array}$ & año & $n_{s m}$ & 2 & 1 \\
\hline $\begin{array}{l}\text { Densidad lograda en la plantación con micro- } \\
\text { riego }\end{array}$ & $\begin{array}{c}\text { plantas/ } \\
\text { ha }\end{array}$ & $\rho_{f}$ & 980 & 980 \\
\hline $\begin{array}{l}\text { Densidad lograda en la plantación con } \\
\text { reposición de marras }\end{array}$ & $\begin{array}{c}\text { plantas/ } \\
\text { ha }\end{array}$ & $\rho f$ & 972 & 802 \\
\hline \multicolumn{5}{|l|}{ Costes } \\
\hline Coste de la instalación del riego & $€ /$ ha & $C d$ & 930,00 & 930,00 \\
\hline Coste de los riegos & $€ /$ ha & $\mathrm{Cr}_{P V}$ & 58,85 & 58,85 \\
\hline Costes totales del sistema de micro-riego & $€ /$ ha & Cwat & 988,85 & 988,85 \\
\hline Beneficios adelantados gracias al micro-riego & $€ /$ ha & BlPV & 256,59 & 256,59 \\
\hline Coste de la planta repuesta & $€ /$ ha & $C p_{P V}$ & 113,57 & 128,47 \\
\hline Coste de las labores de reposición de marras & $€ /$ ha & $C m_{P V}$ & 571,07 & 549,92 \\
\hline Coste total de la reposición de marras & $€ /$ ha & $C_{\text {rep }}$ & 684,64 & 678,39 \\
\hline Lucro cesante (sin riego) & $€ /$ ha & $L P P V$ & 47,61 & 53,86 \\
\hline \multicolumn{5}{|l|}{ Balance } \\
\hline Balance coste-beneficio del micro-riego & $€ /$ ha & $C_{w a t}-B I_{P V}$ & 723,25 & 723,25 \\
\hline $\begin{array}{l}\text { Balance coste-beneficio de la reposición de } \\
\text { marras }\end{array}$ & $€ /$ ha & $C_{r e p}+L P_{P V}$ & 723,25 & 723,25 \\
\hline \multicolumn{5}{|l|}{ Inversión } \\
\hline $\begin{array}{l}\text { Coste por planta instalada con autonomía } \\
\text { hídrica (alternativa micro-riego) }\end{array}$ & $€ /$ planta & Caut & 2,52 & 2,52 \\
\hline $\begin{array}{l}\text { Coste por planta instalada con autonomía } \\
\text { hídrica (alternativa reposición) }\end{array}$ & $€ /$ planta & Caut & 2,23 & 2,69 \\
\hline
\end{tabular}


Conforme al modelo, en el caso a) el umbral de marras es de $M=0,3045$ (tanto por uno). Por lo tanto, si se producen al menos 305 marras por hectárea en la repoblación considerada, el sistema de micro-riego, con un pequeño tubo vertical de PVC hincado en el suelo junto a cada planta, resulta más rentable que la reposición anual de marras. La densidad lograda con el riego es de 980 plantas/ha $(\mu=0,02)$, y la densidad final sin riegos es de 972 plantas /ha, lo que se consigue al tercer año $(N=3)$, tras dos años de reposición de planta $\left(n_{s m}=2\right)$.

El umbral de marras en el caso b) resulta $M=0,4454$ (tanto por uno), debido al mayor valor de la tolerancia $A L F$. A partir de que se produzcan al menos 446 marras por hectárea, el sistema de micro-riego resulta más rentable que la reposición anual de marras. La densidad lograda con el riego es igual al caso anterior: 980 plantas/ha $(\mu=$ 0.02), y la densidad final sin riegos es de 802 plantas/ha, densidad que se consigue al segundo año $(N=2)$, tras un año de reposición de planta $\left(n_{s m}=1\right)$.

En este segundo caso, la tolerancia de marras es mucho más laxa que en el primer caso $(0,2$ frente a 0,03$)$ razón por la cual se admite una densidad final de repoblación bastante menor: 802 frente a 972 pies/ha. Ambos valores no son directamente comparables.

En ambos casos y para el valor umbral $M$, el balance coste-beneficio del microriego $\left(C_{w a t}-B I_{P V}=723,25 € /\right.$ ha $)$ coincide con el balance de la opción de reposición de marras $\left(C_{\text {rep }}+L P_{P V}=723,25 € /\right.$ ha), resultado que satisface la condición planteada [inecuación 3]. Según este dato, para conseguir satisfacer el objetivo de densidad en la repoblación, mediante cualquiera de las dos opciones técnicas, se precisa un incremento del coste neto de la repoblación del 32,8\% $(723,25 /(1.482,00+723,25) \cdot 100=32,8 \%)$. Pero conviene recalcar que cada opción consigue una densidad final distinta lo que aconseja realizar un análisis adicional de la inversión.

Para este fin se pueden referir los costes al número de plantas logradas con autonomía hídrica $\left(C_{\text {aut }}\right)$, sin considerar los beneficios futuros del monte. La reposición de marras con un criterio estricto $(A L F=0,03)$ tiene un $C_{a u t}=2,23 € /$ planta, lo que incrementa el coste por planta en un 50,7\% $((2,23-1,48) / 1,48 \cdot 100=50,7 \%)$, mientras que en el caso de reponer las marras con una tolerancia amplia $(A L F=0,20)$ el coste por planta conseguida es más alto: $81,8 \%\left(C_{a u t}=2,69 € /\right.$ planta $)$. La alternativa del micro-riego incrementa el coste un 70,3\% ( $C_{a u t}=2,52 € /$ planta), valor intermedio entre los anteriores. Adicionalmente, conviene señalar que la inversión en la tecnología de micro-riego elimina el riesgo de marras por estrés hídrico que tiene la opción tradicional de la reposición. Esto supone una ventaja estratégica adicional importante al eliminar la fuerte incertidumbre que suele existir en las precipitaciones de zona árida.

Un segundo examen de la inversión consiste en evaluar la diferencia de beneficios por planta instalada. El coste neto por planta conseguida en la opción del micro-riego es $(723,25+1482,00) / 980=2,25 € /$ planta, valor inferior a los $(723,25+$ $1482,00) / 972=2,27 € /$ planta de la opción de reposición para una tolerancia estricta 
$(A L F=0,03)$ y a $\operatorname{los}(723,25+1482,00) / 802=2,75 € /$ planta de la alternativa de reposición para una tolerancia amplia $(A L F=0,20)$.

La mortandad por falta de agua $(\psi / M)$ es elevada en este lugar, mientras que las marras ajenas al estrés hídrico son muy bajas $\mu=2 \%$. Para el caso a) $\psi=M-\mu=$ $30,45-2,00=28,45 \%$ lo que implica $\psi / M=28,45 / 30,45=0,93$. En el caso b) $\psi=$ $M-\mu=44,54-2.00=42,54 \%$ por lo que $\psi / M=42,54 / 44,54=0,96$. En ambos casos los valores del cociente $\psi / M$ son próximos a la unidad, situación propia de zonas áridas.

En repoblaciones protectoras también se puede resolver el problema mediante un modelo de costes evitados al ser las rentas esperadas bajas ( $R=265,00 € /$ (ha . $\mathrm{y}$ año)). Acudiendo a este modelo simplificado se obtiene $M=0,3781$ (para $A L F=0,03$ ) y $M=0,4472$ (para $A L F=0,20$ ). El efecto del adelanto del beneficio y del lucro cesante inciden poco en el valor umbral $(M)$ que sirve de frontera para decantarse entre una $u$ otra opción.

\section{Bibliografía}

Bainbridge DA (2002) Alternative irrigation systems for arid land restoration. Ecological Restoration 20 (1):23-30. doi:10.3368/er.20.1.23

Bautista S, Alloza JA (2009) Land Restoration to Combat Desertification, in: Bautista, S, Aronson J, Vallejo VR (eds) Innovative Approaches, Quality Control and Project Evaluation. Fundación CEAM 47-72

Catchpoole K, Nester MR (2004) A financial calculator: software for evaluating plantation scenarios. Australian forestry 67 (3):191-193. doi:10.1080/00049158.2004.10674933

Calama R, Manso R, Gordo J, Montero G, Mutke S, Pique M, Vázquez J, Pardos M (2017) Which models are needed for Pinus pinea forests? A review on current state and potential use. In: Mutke $S$, Carrasquinho I, Correia AC (eds) Mediterranean pine nuts from forests and plantations. International Meeting on Mediterranean Stone Pine for Agroforestry: AgroPine2016. CIHEAM, Oeiras (Portugal), pp 27-42

Del Río J, Reque JA, Martínez de Azagra A (2018) To replant or to irrigate: A silvicultural decision model for afforestation projects. Forest Policy and Economics 93:18-29. doi:10.1016/j.forpol.2018.05.007

Del Río J, Gómez E, Reque JA, Martínez de Azagra A (2013) Reponer marras o regar brinzales: una disyuntiva a analizar en zona árida. In Martínez C, Lario F, Fernández B (eds) Avances en la restauración de sistemas forestales Técnicas de implantación. Sociedad Española de las Ciencias Forestales, Asociación Española de Ecología Terrestre, pp 13-18

Faias SP, Palma JHN, Barreiro SM, Paulo JA, Tomé M (2012) Resource communication. sIMfLOR - platform for portuguese forest simulators. Forest Systems 21 (3):543-548. doi:10.5424/fs/2012213-02951

Harrinson S (2002) Simulation Philosophy and Methods. In: Harrison S, Herbohn J, Mangaoang E, Vanclay J (eds) Socio-economic Research Methods in Forestry: A Training Manual. Proceedings of an International Training Workshop held in the College of Forestry at Leyte State University, Visca, Baybay, The Philippines, over the period 4-10 February, 2002. Cooperative Research Centre for Tropical Rainforest Ecology and Management. Rainforest CRC, Cairns, pp 73-84

Hennessy N, Lawlor D (2000) Computer software requirements in Forest Management. Coford

Hepburn C., Koundouri PH (2007) Recent advances in discounting: implications for forest economics. Journal of Forest Economics 13 (2):169-189

Mangaoang EO (2002) A Forester's Perspective of the Socio-economic Information Requirements f.or Forestry in Leyte. In: Harrison S, Herbohn J, Mangaoang E, Vanclay J (eds) Socio-economic Research 
Methods in Forestry: A Training Manual. Proceedings of an International Training Workshop held in the College of Forestry at Leyte State University, Visca, Baybay, The Philippines, over the period 4-10 February, 2002. Cooperative Research Centre for Tropical Rainforest Ecology and Management. Rainforest CRC, Cairns

Muys B, Hynynen J, Palahí M, Lexer MJ, Fabrika M, Pretzsch H, Gillet F, Briceño E, Nabuurs GJ, Kint V (2010) Simulation tools for decision support to adaptive forest management in Europe. Forest Systems 19:86-99. doi:0.5424/fs/201019S-9310

Martínez de Azagra A, Del Río J (2012) Los riegos de apoyo y de socorro en repoblaciones forestales. Foresta 53:32-44

Moles AT, Westoby M (2004) What do seedlings die from and what are the implications for evolution of seed size? Oikos 106:193-199. doi:10.1111/j.0030-1299.2004.13101.x

Oria de Rueda JA (2007) Hongos y setas. Tesoro de nuestros montes. Cálamo, Palencia

Renaud K, Van Biljon J (2008) Predicting technology acceptance and adoption by the elderly: a qualitative study. In, Proceedings of the 2008 annual research conference of the South African Institute of Computer Scientists and Information Technologists on IT research in developing countries: riding the wave of technology. ACM, pp 210-219

Serrada R, Navarro RM, Pemán J (2005) Quality in reforestation: an approach from silviculture and ecophysiology. Forest Systems 14 (3):462-481. doi:10.5424/943 


\section{Capítulo 7. Estimación del tamaño potencial del mercado de sistemas de riego de brinzales en plantaciones forestales en tierras áridas}

La manera más directa de evitar las marras por estrés hídrico consiste en regar los brinzales, para lo cual se han desarrollado sistemas específicos de riego localizado. Se desconoce el tamaño de mercado de los sistemas de riego forestal. Este capítulo acota el potencial de negocio del riego forestal a partir de datos sobre reposición de marras. Se propone y desarrolla una metodología basada en el modelo TAM-SAM-SOM para obtener una estimación del orden de magnitud del mercado potencial para el riego de brinzales en zonas secas. 


\section{Introducción}

El mercado ofrece novedosas tecnologías no convencionales para la aplicación de riegos de establecimiento, socorro y supervivencia en plantaciones de brinzales. A pesar de su eficacia para evitar las marras por estrés hídrico, el riego introduce un sobrecoste en los proyectos de plantación de árboles y arbustos, lo que supone una incertidumbre en la elección de esta alternativa por parte de los consumidores que implica una ausencia de la inversión por parte de los fabricantes. Para corregir esta situación de incertidumbre es necesario determinar previamente el tamaño del mercado (Denault, 2017).

En un mercado novedoso que introduce productos innovadores, pero con falta de información sobre la demanda; la estimación del tamaño del mercado recurre al modelo TAM-SAM-SOM (Blank y Dorf, 2012) con métodos de ratios en cadena o aproximaciones de «arriba -abajo» (Hague et al., 2013).

El presente trabajo tiene por objetivo determinar el tamaño del mercado para el cuidado cultural del riego de establecimiento apoyo y socorro de brinzales en los proyectos de plantación.

\section{Material y métodos}

El modelo TAM-SAM-SOM (Diresta et al., 2015) define tres tamaños de mercado para un producto o servicio. El tamaño de mercado accesible (TAM), es la demanda potencial para el productor de un grupo de consumidores que tiene una restricción presupuestaria y preferencias dadas: en mercados maduros equivale al volumen de operaciones de un sector. El tamaño de mercado servible ( $S A M)$, es la fracción del mercado accesible al que se puede proporcionar el producto en función de la competencia y los canales de distribución. El tamaño de mercado obtenible (SOM), reduce el mercado servible en función de la intención o probabilidad de compra del consumidor. En este trabajo, TAM es el tamaño del mercado de la gestión de marras de brinzales por estrés hídrico. El SAM es el tamaño de mercado accesible para el microriego de brinzales y el $S O M$, es el tamaño de mercado obtenible por el micro-riego de brinzales por la actual adopción de la tecnología. Los valores se obtienen en mil millones de dólares internacionales (\$int).

El valor del mercado de las marras por estrés hídrico (TAM) se estima a partir de la hipótesis de que toda la mortalidad es gestionada mediante la reposición de planta. El procedimiento de cálculo de la inversión anual en reposición de planta por estrés hídrico ( $\left.K_{\text {rep}}\right)$ por país en el 2016, es el siguiente. Se halla el área plantada anualmente por país en tierras secas $(P S)$, que se obtiene por diferencia entre los años de inicio y fin de las bases de datos, 2015-1990, en bosques plantados (FAO 1990, 2015) y 2000-2011 del área cosechada en fruticultura (FAO, 2016). A continuación, se calcula la tasa anual de crecimiento $r$ (Puyravaud, 2003) del periodo disponible en la bases de datos; el valor de $r$ se aplica para conocer el valor de PS en el año de referencia $2016\left(P S_{0}\right)$ y en el año 2025 $\left(P S_{\text {end }}\right)$ mediante la siguiente ecuación: $P S_{\text {end }}=P S_{o} \cdot e^{r \cdot \Delta n}$ [1]. El lapso de tiempo $\Delta n=10$ es el habitual en estudios de tamaño de mercado. 


$$
\begin{aligned}
& T A M_{0}=K_{r e p, 0}=P S_{0} \cdot \frac{C_{r e f} \cdot P P A \cdot I_{r e p}}{1000} \\
& T A M_{\text {end }}=K_{r e p, e n d}=P S_{o} \cdot e^{r \cdot \Delta n} \cdot \frac{C_{r e f} \cdot P P A \cdot I_{r e p} \cdot(1+i)^{\Delta n}}{1000}
\end{aligned}
$$

Los cálculos se efectúan para cada base de datos por separado, bosques plantados y frutales, sumando a continuación los resultados de ambas. Los supuestos auxiliares contemplados son: i) la tasa de crecimiento de las plantaciones por país $(q)$ en el periodo 1990 - 2015 se mantiene constante en el periodo 2015-2025; ii) la superficie plantada en tierras áridas $(P S)$ es proporcional a la extensión de las misma en cada país; iii) la inversión en plantaciones de cada país se obtiene fijando como referencia el coste de la repoblación en España $\left(C_{\text {ref }}\right)$, ajustando su valor a la realidad económica de cada país, por el factor de conversión de la paridad del poder adquisitivo de cada país (PPA), proporcionado por el banco mundial (WB, 2016) para convertir los datos en unidas monetarias dólares internacionales (\$int), iv) el coste de las marras es un 30\% del coste de repoblación $\left(I_{r e p}\right), \mathrm{y}$ v) el tipo de interés del dinero es $(i=2 \%)$, valor intermedio entre el tipo de interés actual del Banco Central Europeo y la tasa habitual de descuento social.

Las marras por estrés hídrico pueden ser gestionadas mediante la reposición de planta o con otros cuidados culturales como el riego. El cálculo del SAM considera la hipótesis de que el riego es una técnica sustitutiva de la reposición de plantas para evitar las marras por estrés hídrico en determinadas ocasiones. Para hallar cuándo compite con ventaja es necesario conocer la probabilidad de uso del riego frente a la reposición de planta $\left(I_{w a t}\right)$. La probabilidad depende de la estación forestal considerada, del tipo de riego, de la plantación considerada y de las marras esperadas; a partir de estos datos se puede obtener la distribución geográfica de las situaciones en las que el riego compite con ventaja económica frente a la reposición de marras. De acuerdo al modelo propuesto por Del Río et al. (2018), esto implica hallar el umbral de marras $(M)$ donde el riego es más ventajoso económicamente que la reposición de planta. Aún estamos lejos de disponer de toda la información necesaria que requiere aplicar este modelo a escala internacional para calcular el SAM (ecuación 4), especialmente el valor de $M_{R}$, motivo por el que a partir de este punto se acude a cálculos de razonamiento aproximado.

La función de distribución empírica acumulada de $M$ se obtiene por simulación (Del Río et al, 2018). A partir de ella se calcula que la probabilidad de uso del riego $I_{w a t}$ es de 0,95 para los frutales y de 0,74 para bosques plantados, para un $M_{R}=40 \%$, que es el valor medio considerado a partir de evidencias experimentales y datos estadísticos ( $\mathrm{p}$. ej., Navarro et al., 2014; Çalişkan y Boydak, 2017).

$$
S A M_{0}=T A M_{o} \cdot I_{w a t}[4]
$$

Los supuestos auxiliares del cálculo del $S A M$ son: i) todos los canales de distribución son accesibles, ii) no existe competencia con otros cuidados culturales, iii) el consumidor elige en un mercado con información completa en la que conoce cuál es la opción más ventajosa económicamente entre regar o reponer planta. 
A efectos de este análisis se considera que el valor del SOM (ecuación 5) depende de la probabilidad de adopción tecnológica, evaluada según la función de distribución $F_{B A S S}\left(N_{a}\right)$ del modelo de BASS $(1969,1994)$, donde $N_{a}$ es el número acumulado de adoptantes de la tecnología:

$$
S O M_{0}=T A M_{o} \cdot F_{B A S S}\left(N_{a}\right) \quad[5]
$$

Para calcular el SOM se utiliza el supuesto auxiliar de que el nivel de adopción, en el año 2016, ha conseguido alcanzar al grupo de los innovadores (Rogers, 2003) que tiene un valor de $N_{a}=2,5 \%$, para el cual la función ajustada $F_{B A S S}\left(N_{a}\right)$ es igual a $4,7 \%$, propagándose a partir de ahí en el tiempo según la función $F_{B A S S}\left(N_{a}\right)$. Para ajustar $F_{B A S S}\left(N_{a}\right)$ el procedimiento de cálculo seguido es el siguiente. Los coeficientes $p_{i n} q_{i n}$ se obtienen a partir de los datos experimentales de $N_{a}$ recopilados por Alcón et al. (2011), referidos al nivel de adopción del riego localizado en Murcia (España). Este autor, utiliza el método de Cabral (1990), hallando que la masa crítica del grupo de primeros innovadores en la adopción del riego localizado se alcanzó a los 7,12 años, con $F_{B A S S}\left(N_{a}\right)$ $=24,5 \%$. El ajuste de $F_{B A S S}\left(N_{a}\right)$ proporciona el coeficiente de innovación de $p_{i n}=0,02$ y el de imitación $q_{i n}=0,19$ con $m_{i n}=1$, valores que están dentro del rango detectado por Petridis et al. (2018) para la innovación en tecnologías de la información y la comunicación (TIC) en el sector agroalimentario.

Se emplea la tasa de crecimiento anual compuesto (CAGR) (Puyravaud, 2003) para proyectar el valor de los tamaños de mercado del año de referencia $S A M_{0}$ y $S O M_{0}$ al futuro, $S A M_{\text {end }}$ (ecuación 6) y $S O M_{\text {end }}$ (ecuación 7). CAGR (ecuación 8) es equivalente a la tasa $q$ utilizada por FAO (1995).

$$
\begin{aligned}
& S A M_{\text {end }}=S A M_{o} \cdot(1+C A G R)^{\Delta n} \\
& S O M_{\text {end }}=S O M_{O} \cdot(1+C A G R)^{\Delta n} \\
& C A G R=\left(\frac{T A M_{\text {end }}}{T A M_{o}}\right)^{\frac{1}{\Delta n}}-1
\end{aligned}
$$

\section{Resultados}

El principal resultado obtenido es que se prevé que el tamaño de mercado de la gestión de marras por estrés hídrico accesible por la técnica de reposición de planta y por las tecnologías de cuidados culturales, en el establecimiento de bosques plantados y frutales, pueda alcanzar los 1,19 mil millones de int\$ en 2025, a partir de un valor estimado de 0,72 de mil millones de int\$ en 2016.

En cuanto a los sistemas de micro-riego de establecimiento de brinzales, se prevé que el tamaño del mercado servible potencialmente puede alcanzar los 1,05 mil millones de int\$ en 2025, de un valor estimado 0,63 de mil millones de int\$ en 2016. Estas cifras se ven reducidas si se considera el tamaño de mercado obtenible, el cual se estima en 0,05 mil millones de int\$ en 2025, a partir de un valor estimado de 0,03 de mil millones de int\$ en 2016. 
El mercado conjunto de bosques plantados y frutales tiene una tasa compuesta anual de crecimiento del 5,2\% durante el período de pronóstico, si bien, si se considera de forma aislada el mercado de frutales, se observa que este crece a una tasa compuesta anual del 5,6\% frente a la del 4,3 \% de los bosques plantados.

La aplicación de este método permite dibujar un mapa con el resultado del tamaño de mercado por país (TAMo, TAMend) (Figura 1).

Los tamaños de mercado potencial calculados para el riego de brinzales en las plantaciones forestales, se comparan con los valores de informes de mercados globales reales relativos de sectores próximos al regadío agrario (Tabla 1), para contrastar la validez del orden de magnitud obtenido.

\section{Discusión}

Los indicadores de tamaño del mercado TAM, SAM y SOM y de crecimiento $C A G R$, son un requisito informal para atraer o acceder a inversión (Diresta et al., 2015), usado en los modelos de evaluación de la tecnología, bien sea en el criterio de atractivo del mercado o en el de mercado potencial (Noh et al., 2018). Disponer de estos índices favorece la transferencia de patentes y estudios y facilita la puesta en marcha de sistemas de producción que abaraten los costes de fabricación y comercialización.

No todas las plantaciones en las que es posible el riego de establecimiento (Del Río et al., 2016) están recogidas en las bases de datos disponibles, en especial la categoría de plantaciones fuera de bosques como son la xero-jardinería o la protección de infraestructuras; en consecuencia, los tamaños de mercado obtenidos están infradimensionados con respecto a su verdadero valor. El sector forestal tiene el reto de crear bases de datos globales en su extensión y específicas en su contenido para abordar el seguimiento de la actividad repobladora (Pemán, 2015; Keenan et al., 2015). A medida que se disponga de datos más adecuados, los resultados de este estudio podrán ser mejorados por el perfeccionamiento de las hipótesis y supuestos auxiliares que inicialmente se han establecido.

Las simplificaciones implicadas en el cálculo del tamaño de mercado de la inversión anual en reposición de planta en este estudio (TAM) hace que su estimación sea un valor potencial. El tamaño de mercado de sistemas de riego de establecimiento brinzales $(S A M)$ también debe considerarse potencial puesto que, a las consideraciones anteriores, se añade que se basa en el supuesto de encontrarse en un mercado con información perfecta y pleno acceso a la tecnología del micro-riego que permite decantarse a la gestión de las marras por estrés hídrico por el riego cuando compite con ventaja económica frente a la reposición de planta. El procedimiento de cálculo seguido hace que deba realizarse la misma apreciación de mercado potencial para el SOM por heredar en su cálculo las consideraciones de los mercados anteriores y por los supuestos auxiliares de adopción tecnológica. Los mercados reales solo podrán obtenerse de cifras de volumen de negocio real, o en su defecto, cuando se disponga de indicadores de la cuota de mercado del riego frente la reposición de planta. 
Los datos de control verifican que el mercado del sector de la gestión de marras es claramente inferior al mercado de riegos del sector agrario. El crecimiento anual compuesto del sector de las plantaciones y frutales es aproximadamente la mitad que en el sector agrario. El tamaño del mercado en Estados Unidos, China e India permite la existencia de empresas, en el resto de países el tamaño de mercado solo admite pequeñas y medianas empresas.

Los estudios de innovación forestal (Moller y Shafer, 1981; Segman, 1983) comenzaron a fraguarse dos décadas después del comienzo de los trabajos sobre innovación agraria (Schut et al., 2014). La cantidad de publicaciones en ambos sectores es muy desigual, tendencia que continua en la actualidad, con un mayor dinamismo del sector agrario donde puede observase que el sector forestal representa el 1,4\% de los 6.410 artículos indexados por la innovación agraria en el periodo 2015-2017 según datos de Google Scholar. El sector forestal tiene la oportunidad de orientar trabajos sobre innovación forestal, impulsado por las aportaciones de la innovación agraria, puesto que ambos comparten la integración de la innovación en las políticas de desarrollo (Weiss, 2011) aunque presenten características económicas y de innovación dispares (Pavitt, 1984; Weiss, 2011).

El tamaño del mercado tiene gran influencia en los recursos económicos destinados a la innovación; por ejemplo, en la industria farmacéutica se ha hallado una elasticidad de la innovación de 0,23 (Dubois et al., 2015). Esta tendencia ha sido ratificada en la agricultura por Charlot et al. (2015). Aunque estos autores no calculan su valor, ponen en evidencia que la elasticidad de la innovación agraria depende en gran medida del precio en cultivos híbridos y de la superficie cultivada en cultivos no híbridos. La aplicación de estas metodologías en el ámbito forestal, abre un camino para determinar los recursos económicos disponibles en el mercado de la innovación forestal cuando se introducen productos o servicio para los que no existen estadísticas previas de inversión en $\mathrm{I}+\mathrm{D}+\mathrm{i}$. El análisis del tamaño del mercado se verá enriquecido con la incorporación de las externalidades negativas que pueden producir el escalado geográfico de las innovaciones de la agricultura (Wigboldus et al., 2017), del que el riego de brinzales en las plantaciones no es ajeno. 
Tabla 1. Tamaños de mercado y crecimiento de varios sectores en el periodo 2016 a 2025

\begin{tabular}{|c|c|c|c|c|c|c|c|c|c|}
\hline \multirow[b]{2}{*}{ Sector } & \multirow[b]{2}{*}{ Producto } & \multicolumn{2}{|c|}{$\begin{array}{l}\text { Tamaño de } \\
\text { mercado }\end{array}$} & \multirow[t]{2}{*}{ CAGR } & \multirow[t]{2}{*}{ Fuente } & \multirow[t]{2}{*}{$\Delta n$} & \multirow[t]{2}{*}{ Año } & \multicolumn{2}{|c|}{$\begin{array}{c}\text { Tipo de empresa (4) } \\
\text { Año }\end{array}$} \\
\hline & & 2016 & 2025 & & & & & 2016 & 2025 \\
\hline \multirow{3}{*}{ 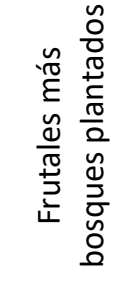 } & $\begin{array}{l}\text { Gestión de marras por estrés hídrico } \\
\text { (reposición de planta - cuidado cultural) }\end{array}$ & 0,72 & 1,19 & 5,2 & TAM & 10 & 2025 & & \\
\hline & $\begin{array}{l}\text { Micro-riego de establecimiento de } \\
\text { brinzales }\end{array}$ & 0,63 & 1,05 & 5,2 & SAM & 10 & 2025 & & \\
\hline & $\begin{array}{l}\text { Adopción del micro-riego de } \\
\text { establecimiento de brinzales }\end{array}$ & 0,03 & 0,05 & 5,2 & SOM & 10 & 2025 & $\begin{array}{l}\text { PYME } \\
\text { Mediana }\end{array}$ & $\begin{array}{l}\text { PYME } \\
\text { Mediana }\end{array}$ \\
\hline \multirow{3}{*}{ 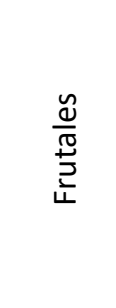 } & $\begin{array}{l}\text { Gestión de marras por estrés hídrico } \\
\text { (reposición de planta - cuidado cultural) }\end{array}$ & 0,47 & 0,81 & 5,6 & TAM & 10 & 2025 & & \\
\hline & $\begin{array}{l}\text { Micro-riego de establecimiento, socorro } \\
\text { y supervivencia de brinzales }\end{array}$ & 0,45 & 0,77 & 5,6 & SAM & 10 & 2025 & & \\
\hline & $\begin{array}{l}\text { Adopción del micro-riego de } \\
\text { establecimiento de brinzales }\end{array}$ & 0,02 & 0,04 & 5,6 & SOM & 10 & 2025 & $\begin{array}{l}\text { PYME } \\
\text { Mediana }\end{array}$ & $\begin{array}{l}\text { PYME } \\
\text { Mediana }\end{array}$ \\
\hline \multirow{3}{*}{ 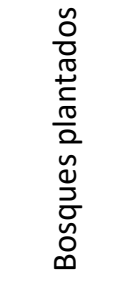 } & $\begin{array}{l}\text { Gestión de marras por estrés hídrico } \\
\text { (reposición de planta - cuidado cultural }\end{array}$ & 0,25 & 0,38 & 4,3 & TAM & 10 & 2025 & & \\
\hline & $\begin{array}{l}\text { Micro-riego de establecimiento, socorro } \\
\text { y supervivencia de brinzales }\end{array}$ & 0,19 & 0,29 & 4,3 & SAM & 10 & 2025 & & \\
\hline & $\begin{array}{l}\text { Adopción del micro-riego de } \\
\text { establecimiento de brinzales }\end{array}$ & 0,01 & 0,01 & 4,3 & SOM & 10 & 2025 & $\begin{array}{l}\text { PYME } \\
\text { pequeña }\end{array}$ & $\begin{array}{l}\text { PYME } \\
\text { pequeña }\end{array}$ \\
\hline \multirow{10}{*}{ 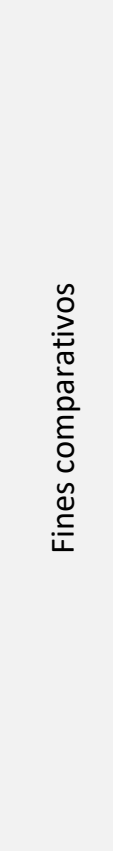 } & $\begin{array}{l}\text { Agricultura inteligente (sofware, } \\
\text { hardware, network, servicio, solución, } \\
\text { aplicación) }\end{array}$ & 5,10 & 15,34 & 11,6 & (1) & 10 & 2025 & & \\
\hline & $\begin{array}{l}\text { Agricultura inteligente (lot: } \\
\text { hardware, sofware, network) }\end{array}$ & 0,68 & 2,32 & 13,1 & (2) & 10 & 2026 & & \\
\hline & $\begin{array}{l}\text { Agricultura inteligente (lot: } \\
\text { hardware, sofware, network) }\end{array}$ & 0,65 & 1,54 & 13,1 & (3) & 7 & 2022 & & \\
\hline & $\begin{array}{l}\text { Micro-irrigación agraria (micro- } \\
\text { aspersión-localizado) }\end{array}$ & 2,53 & 6,87 & 15,3 & (3) & 7 & 2022 & & \\
\hline & Controladores de irrigación & 0,53 & 1,18 & 12,1 & (3) & 7 & 2022 & & \\
\hline & Fumigadoras & 1,75 & 2,63 & 6,0 & (3) & 7 & 2022 & & \\
\hline & $\begin{array}{l}\text { Tecnología de aplicación variable de } \\
\text { insumos (VRT) }\end{array}$ & 1,31 & 2,24 & 8,0 & (3) & 7 & 2022 & & \\
\hline & Componentes de riego localizado & 3,78 & 6,54 & 8,1 & (3) & 7 & 2022 & & \\
\hline & $\begin{array}{l}\text { Aspersión (Pívot central, Ala móvil, } \\
\text { cañón) }\end{array}$ & 1,86 & 4,27 & 12,6 & (3) & 7 & 2022 & & \\
\hline & Pívot central & 0,94 & 1,73 & 9,1 & (3) & 7 & 2022 & & \\
\hline
\end{tabular}

Unidades: TAM, SAM; SOM (miles de millones de \$int); CAGR (\%); $\triangle n$ (años)

Fuentes: (1) Zion Market Research (2018). (2) Transparence Market Research (2018) (3) Markets and Markets (2018) (4) Según volumen de facturación, a partir de la clasificación del Reglamento (UE) no 651/2014 de la Comisión Europea. 


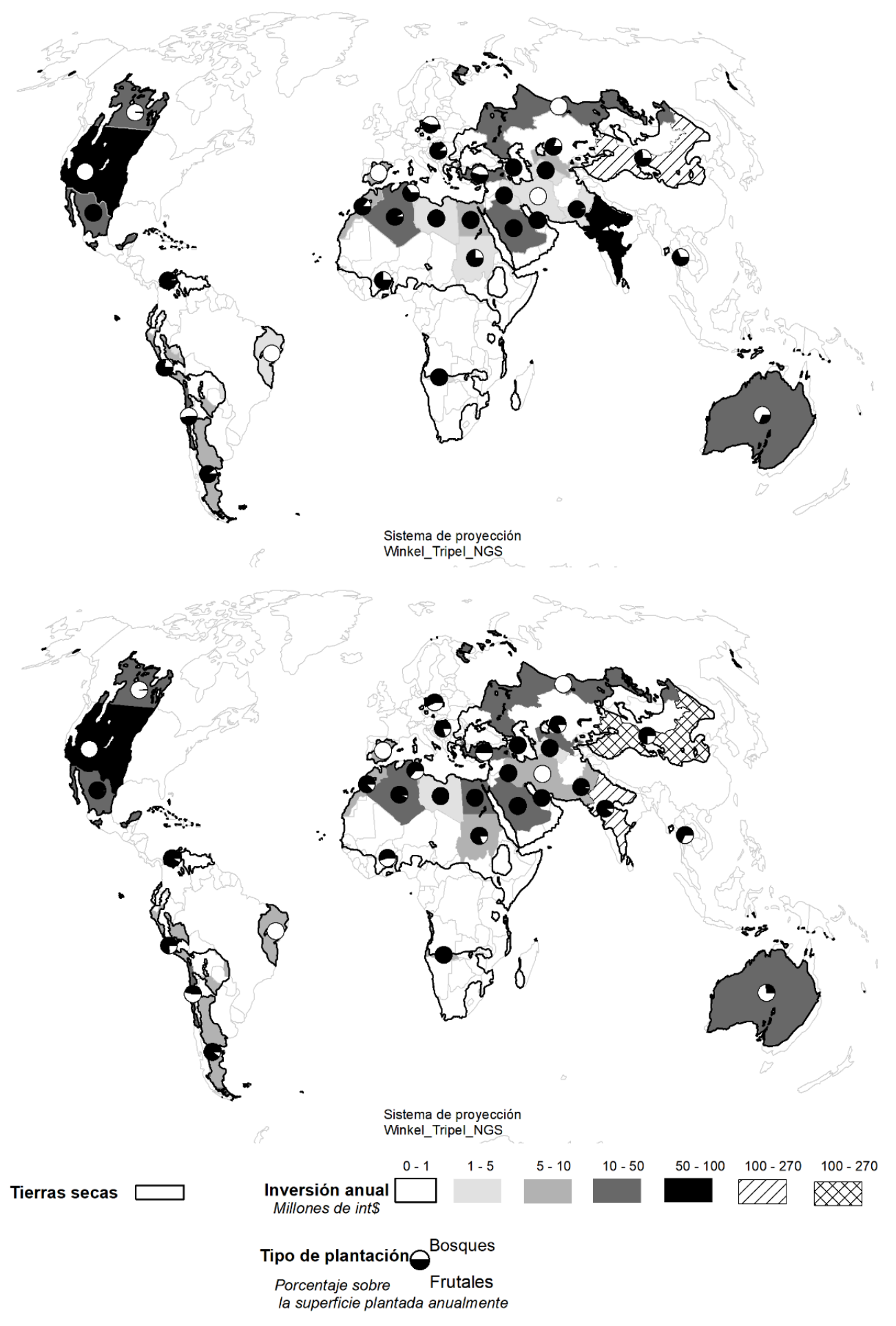

Figura 1. Mapa de inversión anual (int\$) en reposición de planta en tierras áridas y en bosques plantados y frutales. Mapa superior referido al año 2016 y mapa inferior con la predicción del año 2025

La masa crítica hallada por Alcón et al. (2011) es una cifra alejada del $F_{B A S S}\left(N_{a}\right)=$ 15 \% del modelo teórico de Rogers (2003) y de los valores empíricos de otros sectores 
que están en el rango del 5\% al 15\% (Mahler y Rogers, 1999; Cool et al., 1997) y que ponen de manifiesto la difusión lenta de las innovaciones agrarias. Los valores que se han obtenido de CAGR son menores que los de referencia del sector agrario, lo que indica que en el ámbito de las plantaciones forestales la difusión de la innovación pueda ser más lenta que en el sector agrario, estudios posteriores permitarán confirmar o rechazar esta hipótesis.

\section{Bibliografía}

Alcón F, De Miguel, MD, Burton M (2011) Duration analysis of adoption of drip irrigation technology in southeastern Spain. Technological Forecasting and Social Change 78:991-1001

Bass FM (1969) A New Product Growth for Model Consumer Durables. Management Science 15:215-227

Bass FM, Krishnan TV, Jain DC (1994) Why the Bass model fits without decision variables? Marketing Science 13:203-223

Blank S, Dorf B (2012) The startup owner's manual: The step-by-step guide for building a great company. Pescadero, CA: K\&S Ranch. Inc. Publishers

Cabral LM (1990) On the adoption of innovations with 'network'externalities. Mathematical Social Sciences 19:299-308

Çalişkan S, Boydak M (2017) Afforestation of arid and semiarid ecosystems in Turkey. Turkish Journal of Agriculture and Forestry 41 (5):317-330

Charlot S, Dridi C, Lemarié S (2015) Market size and innovation: An application to the French seed market for large crops (2015) AAEA and WAEA Joint Annual Meeting, July 26-28, San Francisco, California. Agricultural and Applied Economics Association and Western Agricultural Economics Association.

Cool KO, Dierickx I, Szulanski G (1997) Diffusion of innovations within organizations: Electronic switching in the Bell System 1971-1982. Organization Science 8:543-559

Del Río J, Reque JA, Martínez de Azagra A (2016) Viabilidad económica de los microrriegos en repoblaciones. Cuadernos de la Sociedad Española de las Ciencias Forestales 42:75-90

Del Río J, Reque JA, Martínez De Azagra A (2018) To replant or to irrigate: A silvicultural decision model for afforestation projects. Forest Policy and Economics 93:18-29. doi:https://doi.org/10.1016/j.forpol.2018.05.007

Denault JF (2017) The Handbook for Market Research for Life Sciences Companies: Finding the Answers You Need to Understand Your Market. CRC Press

DiResta R, Forrest B, Vinyard R (2015) The Hardware Startup: Building Your Product, Business, and Brand. O'Reilly Media Inc

Dubois P, de Mouzon O, Scott-Morton F, Seabright P (2015) Market size and pharmaceutical innovation. The RAND Journal of Economics, 46: 844-871. doi:10.1111/1756-2171.12113

FAO (1995) Global Forest Resources Assessment 1990. Global Synthesis. FAO, Roma, Italia (FRA1990)

FAO (2015) Global Forest Resources Assessment 2015: how are the world's forests changing? (FRA2015). Desk reference. FAO, Roma, Italia

FAO (2016) FAOSTAT on-line database, Food and Agriculture Organization. Production. Crops. FAO, Roma, Italia

Hague PN, Hague N, Morgan CA (2013) Market Research in Practice How to Get Greater Insight from Your Market. Kogan Page, London 
Keenan RJ, Reams GA, Achard F, de Freitas JV, Grainger A, Lindquist E (2015) Dynamics of global forest area: Results from the FAO Global Forest Resources Assessment 2015. Forest Ecology and Management 352:9-20

Köhl M, Lasco R, Cifuentes M, Jonsson Ö, Korhonen KT, Mundhenk P, De Jesus J, Stinson G (2015) Changes in forest production, biomass and carbon: Results from the 2015 UN FAO Global Forest Resource Assessment. Forest Ecology and Management 352:21-34

MacDicken KG (2015) Global Forest Resources Assessment 2015: What, why and how? Forest Ecology and Management 352:3-8

Mahler A, Rogers EM (1999) The diffusion of interactive communication innovations and the critical mass: the adoption of telecommunications services by German banks. Telecommunications policy 23:719740

Markets and Markets 2018. Press Releases India. Markets and Markets.

Moeller GH, Shafer EL (1981) Important Factors in the Forestry Innovation Process. Journal of Forestry 79:30-32

Navarro RM, del Campo AD, Ceacero CJ, Quero JL, Hermoso de Mena J (2014) On the importance of topography, site quality, stock quality and planting date in a semiarid plantation: Feasibility of using low-density LiDAR. Ecological Engineering 67:25-38

Noh H, Seo JH, Sun Yoo H, Lee S (2018) How to improve a technology evaluation model: A data-driven approach. Technovation 72-73:1-12

Pavitt K (1984) Sectoral patterns of technical change: Towards a taxonomy and a theory. Research Policy 13:343-373

Pemán J (2015) Lecciones aprendidas y tareas pendientes en la actividad repobladora y viverística. Cuadernos de la Sociedad Española de las Ciencias Forestales 39:177-195

Puyravaud J-P (2003) Standardizing the calculation of the annual rate of deforestation. Forest Ecology and Management 177 (1):593-596. doi:10.1016/S0378-1127(02)00335-3

Research TM (2018) Press release. Smart Agriculture Market. Report Code: TMRGL10871, 2018 ed. Transparence Market Research, Pune, India

Rogers EM (2003) Diffusion of innovations (5 ed) Free Press, New York:

Segman R (1983) Fostering and managing innovation in the forest service. The Journal of Technology Transfer 7:21-44

Schut M, Rodenburg J, Klerkx L, Van Ast A, Bastiaans L (2014) Systems approaches to innovation in crop protection. A systematic literature review. Crop Protection 56:98-108. doi:10.1016/j.cropro.2013.11.017

Transparence Market Research (2018) Press release. Transparence Market Research, Pune, India.

Weiss G (2011) Theoretical Approaches for the Analysis of Innovation Processes and Policies in the Forest Sector, in: Weiss G, Pettenella D, Ollonqvist P, Slee B (eds), Innovation in forestry: territorial and value chain relationships. CABI Publishing, United Kingdom, pp 10-34.

Wigboldus S, Klerkx L, Leeuwis C, Schut M, Muilerman S, Jochemsen H (2016) Systemic perspectives on scaling agricultural innovations. A review. Agronomy for Sustainable Development 36 (3):46. doi:10.1007/s13593-016-0380-z

Banco Mundial (2016) PIB per cápita, PPA (\$ a precios internacionales actuales). Banco Mundial, base de datos del Programa de Comparación Internacional. Accesible en: https://datos.bancomundial.org/indicador/NY.GDP.PCAP.PP.CD

York J (2018) Putting Lean Startup into Perspective: A Novel Approach for Discovering and Developing a Successful Business Mode. Archives of Business Administration and Management 1:1-16 
Revisión y evaluación técnico - económica de los sistemas de micro-riego usados en repoblación forestal

Zion Market Research (2018) Press release. ZION Market Research. Maharashtra, India 


\section{Capítulo 8. Conclusiones}

En este capítulo se exponen las conclusiones de la tesis doctoral siguiendo el orden de los capítulos precedentes; posteriormente se resumen en once conclusiones principales.

\section{Conclusiones por capítulo}

\section{Capítulo 1: El riego de brinzales en la acción repobladora}

Los sistemas de micro-riego para el establecimiento de brinzales resultan atractivos experimentalmente, pero dudosos en la práctica. Para poder despejar estas incertidumbres se requiere de información que pueda incorporarse en modelos de decisión selvícola que tengan en consideración la economía de los cuidados culturales.

\section{Capítulo 2: Sistemas de micro-riego de brinzales}

Los micro-riegos de brinzales difieren de los riegos agrícolas tradicionales, tanto en el objetivo que persiguen como por los sistemas de humectación que utilizan: buscan el arraigo y la instalación del arbolado en vez de una producción o cosecha y poseen unas ecuaciones características diferentes a los sistemas convencionales.

Actualmente existe una amplia oferta tecnológica para el micro-riego de brinzales que va desde las clásicas vasijas porosas de barro hasta los destiladores solares, pasando por la utilización de tubos verticales hincados, tuberías horizontales de drenaje, recipientes con mechas, fieltros o rezumadores variados.

El mejor sistema de riego a emplear depende de numerosos factores que el técnico debe considerar y ponderar. Este capítulo de revisión proporciona datos y criterios con los que realizar esta elección.

Los sistemas de riego aquí descritos suponen un avance importante para la selvicultura en zonas áridas. Desde un punto de vista profesional, estos métodos abren un amplio abanico de posibilidades, entre otras, la de poder extender el periodo de plantación a lo largo de casi todo el año.

Se trata de un sector innovador y dinámico que incorpora numerosas patentes de reciente creación. Como tendencias tecnológicas de futuro previsibles dentro de este interesante sector emergente, se pueden apuntar dos: la utilización creciente de materiales plásticos permeables (de fabricación más uniforme y económica que la cerámica) y la conexión de los emisores individuales a una red de riego (opción que necesita de un número mínimo de puntos de riego por hectárea para resultar rentable y que exige algunos cambios de diseño respecto de los emisores individuales aislados). 
Por tratarse de un sector de riego emergente, está en pleno desarrollo y expansión. La revisión ha mostrado las áreas de investigación y desarrollo que presentan más oportunidades: la mejora de los propios sistemas de riego; el análisis de los costes de fabricación, adquisición, instalación y manejo; la eficiencia en la aplicación del agua; la determinación de la durabilidad en monte o el efecto que tienen en el desarrollo radicular de los brinzales, entre los aspectos más importantes.

\section{Capítulo 3: Revisión sistemática de publicaciones}

La literatura científica muestra un interés creciente por el micro-riego de brinzales en una amplia área geográfica mundial, especialmente en las regiones áridas.

Las grandes áreas de interés de las publicaciones son la relativa a la planificación, la descripción de experiencias sobre el uso del riego en la producción de cultivos en geografías sensibles a los efectos de la desertificación y del cambio climático, y la caracterización del funcionamiento hidráulico de los sistemas. La revisión efectuada detecta el ámbito hidráulico y de la adopción de la innovación como los temas emergentes en este campo.

Desde esta perspectiva técnica, las publicaciones se han centrado en evaluar la aplicación del micro-riego por goteo subsuperficial, principalmente en su efecto sobre cultivos arbóreos con producciones de alto valor económico, sin que los temas relacionados con el establecimiento y supervivencia de los brinzales y el análisis de la oferta tecnológica haya recibido la misma atención.

\section{Capítulo 4: Evaluación de la eficiencia técnica}

La evaluación de la eficiencia técnica permite trazar un mapa del estado actual de la tecnología del riego de brinzales que proporcione criterios con los que comparar los múltiples sistemas de riego de brinzales que oferta la industria. Conocer la restricción tecnológica orienta la gestión del proceso productivo e incorpora la eficiencia técnica como un dato a considerar en la elección de los sistemas de riego de brinzales.

Para realizar este tipo de riegos, el mercado proporciona una variada oferta de sistemas de micro-riego basados en distintos fundamentos hidráulicos de entrega de agua. Utilizando únicamente datos bibliográficos, se ha detectado que los fundamentos tienen muy desigual eficiencia técnica.

El sistema de referencia es «Botella PET con mecha» y el fundamento hidráulico de entrega de agua de mayor eficiencia es el de «Evaporación y condensación». A cierta distancia de ellos se sitúan sistemas que son competitivos en grado alto y medio como son: Konkom, Deep pipes, Porous capsules, Pitchers with wicks. El análisis envolvente de datos recomienda mantener su eficacia de aplicación de agua, con una mejora en la gestión de su proceso productivo para abaratar los costes de producción, comercialización e instalación y favorecer una contracción de los insumos. Este esfuerzo debe intensificarse en los sistemas con baja o muy baja competitividad: Difference in water potential, Buried pitchers, Capillarity, Buried stones pocket, RIES bottles, Irrigasc, Eco Bag ${ }^{\circledR}$, 
Infiltration, Waterboxx ${ }^{\circledR}$, Buried diffuser ${ }^{\circledR} \mathrm{y}$ Microreservoir ${ }^{\circledR}$. Al mismo tiempo, en este grupo los sistemas Horizontal perforated pipes, Infiltration, Irrigation of tree basins with hose operan fuera de la escala del mercado.

Las técnicas de irrigación convencionales Surface irrigation Sprinkler irrigation Micro-sprinkler irrigation, Drip irrigation, Surface irrigation y el fundamento hidráulico Working pressure son los más ineficientes técnicamente para el riego de brinzales y están muy alejados del grupo de referencia. Además, los resultados obtenidos indican que la utilización de estos sistemas de riego, especialmente los convencionales, está fuera de la escala y tamaño óptimo del mercado del riego de brinzales. El motivo es que la capacidad de las empresas está dimensionada para fabricar sistemas de riego destinados a cultivos agrícolas de mayor beneficio económico. La eficiencia de escala muestra la existencia de un problema estructural: los sistemas de riego convencional tienen una baja eficiencia de aplicación de agua para el coste que tienen. La adaptación al mercado de las plantaciones de árboles y arbustos conlleva la reducción de su escala o tamaño. Para lograrlo es necesario realizar ajustes en el rendimiento de la organización que reduzcan la infrautilización de recursos, debido al sobredimensionamiento que tienen con respecto al resto del mercado.

En el sector del riego de brinzales, la eficiencia técnica es muy dependiente del coste de la tecnología debido a los altos niveles de eficiencia de aplicación de agua alcanzados por los sistemas no convencionales. Por este motivo, el coste del sistema eficiente, dentro del grupo de los muy competitivos, es el que condiciona el campo de aplicación potencial de la tecnología del riego en la reforestación de tierras áridas; para el resto de sistemas, la versatilidad de situaciones y plantaciones en las que puede emplearse el riego se reduce a medida que los sistemas tienen menor eficiencia técnica.

La determinación de la eficiencia técnica de los sistemas de irrigación para el establecimiento de brinzales en los proyectos de repoblación podrá ser más exacta a medida que estén disponibles más datos sobre el funcionamiento hidráulico de los sistemas de riego y de los procesos productivos implicados en su fabricación. En este sentido será de utilidad incorporar las variables utilizadas habitualmente en el riego agrícola convencional, como costes de energía y mano de obra.

\section{Capítulo 5: Modelo MThreshold}

MThreshold es un modelo de decisión que compara dos opciones alternativas para gestionar una plantación, con y sin riego de brinzales, proporcionando el valor umbral $M$ que hace comparable ambas opciones desde el punto de vista económico. El modelo emplea variables de entrada y ofrece variables de salida que son de uso común en el sector forestal, por lo que es fácil de comprender y utilizar.

Con la finalidad de ilustrar la utilización del modelo, este se aplica a trece casos de estudio en los que se obtienen valores del umbral $M$ muy diferentes (entre «cero»y algo más de «0,6») lo que revela la utilidad práctica del modelo como herramienta de toma de decisiones informada para proyectistas y gerentes en la elaboración de 
proyectos de plantación, evitando reacciones excesivas o insuficientes ante un problema tan importante como es la supervivencia de los brinzales en condiciones de estrés hídrico. El modelo también puede resultar atractivo para los fabricantes de sistemas de riego orientados al sector forestal, ya que les permite poner precios competitivos a sus productos.

El análisis de incertidumbre del modelo muestra la gran variabilidad de $M$ según las características de la plantación y el sistema de riego considerados, lo que permite identificar grupos de plantación según su aptitud a la aplicación del riego frente la reposición de planta.

Cuanto más árida sea la estación forestal en la que se realiza la plantación, mayor será el nivel de marras esperado $\left(M_{R}\right)$. Como consecuencia, el riego, especialmente el micro-riego de alta eficiencia, se convierte en la opción más atractiva. El riego de brinzales es competitivo en situaciones en las que el valor umbral $M$ es bajo. Este es el caso de las plantaciones con límites estrictos de tolerancia de fallos (ALF bajo), un ingreso neto anual alto $(R)$ y una entrada en producción temprana ( $e$ baja). Otros factores que favorecen la alternativa del riego frente a la reposición de marras son las costosas preparaciones del terreno, las plantas con un alto coste unitario y una tasa de interés baja. Por el contrario, para forestaciones con bajos costes de preparación del terreno, plantas baratas, altas densidades de plantación y una alta tolerancia de fallos, la ventaja del riego permanecerá limitada a rodales pequeños imposibles de reforestar sin riego suplementario.

\section{Capítulo 6: Software del modelo}

La herramienta informática desarrollada es versátil, permitiendo trabajar en cualquier contexto geográfico y con diseños de plantación y riego definidos por el usuario con total libertad. La posibilidad de configurar la herramienta ofrece respuesta tanto a las inquietudes del selvicultor y del arboricultor como a las del productor y/o comercializador de los distintos sistemas de riego. Las decisiones técnicas a adoptar en xero-jardinería, xero-paisajismo, arboricultura, protección de infraestructuras, creación de cortavientos, repoblaciones protectoras o productoras y restauraciones vegetales (en general) pueden verse apoyadas con los resultados que ofrece este nuevo software. Así mismo, MThreshold puede convertirse en una herramienta útil para el desarrollo, la fabricación y la política de precios de nuevos y de futuros sistemas de riego localizado, tanto en el sector forestal como en el sector agrícola.

\section{Capítulo 7: Tamaño de mercado de los sistemas de micro-riego forestal}

El tamaño de mercado y la inversión en innovación están relacionados. En cuanto a los sistemas de micro-riego de establecimiento de brinzales, se prevé que el tamaño del mercado servible potencialmente pueda alcanzar los 1,05 mil millones de int\$ en 2025, a partir de un valor estimado 0,63 mil millones de int\$ en 2016. Estas cifras se ven 
reducidas si se considera la adopción de la innovación; de ahí que el tamaño de mercado obtenible potencialmente sea menor, pudiendo alcanzar los 0,05 mil millones de int\$ en 2025, a partir de un valor estimado 0,03 de mil millones de int\$ en 2016. El tamaño de mercado obtenible es propio de un sector de PYMES pequeñas o micro-PYMES con una distribución geográfica local.

La previsión apunta hacia un crecimiento del mercado mayor en el ámbito de las plantaciones de frutales que en el sector de los bosques plantados. Por este motivo, las empresas que producen o comercializan sistemas de micro-riego pueden obtener una mayor expansión si se dirigen preferentemente al sector de los árboles frutales, pero sin descuidar el sector de las plantaciones y repoblaciones forestales.

El volumen real de negocio de los cuidados culturales en la reposición de planta por estrés hídrico en las tierras secas y la cuota de mercado del riego frente a la reposición de planta son, hoy en día, una incógnita que impide conocer el tamaño real del mercado y ajustar los valores potenciales obtenidos. 


\section{Conclusiones principales}

1.- Los riegos de apoyo y de socorro resultan muchas veces convenientes; e incluso llegan a ser imprescindibles en ciertos lugares y rodales de repoblación.

2.- El riego de brinzales es localizado, suplementario, deficitario, preferentemente sub-superficial, de muy baja frecuencia, sin necesidad de presión, temporal, con alta eficiencia de aplicación y con una dotación de agua muy escasa, por lo que puede hablarse de micro-riego.

3.- Existen interesantes sistemas tradicionales de riego localizado y deficitario aplicables en repoblación forestal, como por ejemplo el riego a través de vasijas de barro cocido, pero en los últimos tiempos el mercado proporciona nuevos sistemas de microriego forestal que amplían las posibilidades de elección al proyectista.

4.- En la revisión de métodos de riego efectuada se describen catorce sistemas diferentes y específicos de micro-riego forestal que pueden clasificarse en cinco grupos, atendiendo al fundamento de entrega de agua que utilizan: infiltración, presión hidrostática, diferencia de potencial hídrico, capilaridad y destilación solar.

5.- Otra posible clasificación de los sistemas de micro-riego atiende a su eficiencia técnica, la evaluación comparativa demuestra que los sistemas de micro-irrigación y su fundamento de funcionamiento hidráulico son más eficientes para el riego de brinzales que los sistemas convencionales de riego usados en agricultura.

6.- La gestión selvícola de las marras por estrés hídrico comienza en la redacción del proyecto de repoblación. Para elegir la mejor opción, el técnico debe disponer de herramientas que faciliten su labor. Con esta finalidad se ha desarrollado el modelo MThreshold, que obtiene el umbral de marras a partir del cual la opción del micro-riego resulta competitiva desde el punto de vista económico en comparación con la opción tradicional de reponer las marras que se produzcan.

7.- El modelo se articula en un sistema de dos inecuaciones diofánticas y en una regla de decisión. Tiene catorce parámetros de entrada con los que obtiene dos parámetros de salida, siendo el umbral de marras la variable fundamental a considerar. Por comparación del mencionado valor umbral con el nivel de marras esperado en la estación forestal, si no se aplican riegos de establecimiento, el proyectista puede tomar una decisión técnica fundamentada.

8.- El modelo se aplica a trece casos de estudio que abarcan una amplia gama de situaciones: desde repoblaciones protectoras del suelo o de infraestructuras estratégicas hasta plantaciones truferas o de árboles frutales, pasando por plantaciones multifuncionales, o productoras de madera o de setas, repoblaciones en áreas críticas o en tierras agrícolas, creación de barreras cortavientos y - también - plantaciones para xero-jardinería. El umbral de marras de cada caso resulta muy diferente, estando comprendido entre el $3 \%$ y el $62,5 \%$. 
9.- El modelo se ofrece informatizado lo que facilita su uso. También permite abordar un análisis de sensibilidad de todos sus parámetros. Al respecto, las variables frente a las que el umbral de marras es más sensible son las siguientes: la densidad de plantación, el precio unitario de las plantas, el coste unitario del riego, la renta económica media del monte objetivo, el tiempo de espera hasta la entrada en producción del monte y la tasa de interés anual.

10.- Los sistemas de micro-riego de brinzales tienen una gran fracción accesible del mercado de gestión de marras por estrés hídrico, frente a la reposición de planta u otros cuidados culturales. A pesar de estas perspectivas, el tamaño del mercado obtenido en la actualidad por los sistemas de micro-riego está muy alejado del mercado servible por la tecnología, cuya difusión está condicionada por la información disponible sobre cuándo es posible usar el riego y los niveles de adopción de la tecnología.

11.- De cara a un futuro próximo, conviene señalar que el modelo se puede extender fácilmente en dos sentidos: incorporando diferentes estrategias de riego y de reposición de marras, y considerando otros cuidados culturales. Para conseguir este propósito, ciertas hipótesis y suposiciones deberán ser modificadas o ajustadas, lo que dará lugar a un conjunto de ecuaciones diferentes (aunque similares) a las desarrolladas en este trabajo. 


\section{ANEJO 1. Relación de publicaciones realizadas como consecuencia de la tesis}

Durante la elaboración de la presente tesis se han ido realizando una serie de publicaciones, en congresos nacionales, revistas y en un libro con los resultados parciales que se obtenían según se progresaba en la elaboración del trabajo. Estas publicaciones se presentan a continuación siguiendo un orden en función del año de su publicación. 
Las aportaciones subrayadas y señaladas con asterisco, cumplen con los requisitos de la modalidad ordinaria de tesis doctoral establecidos por la Universidad de Valladolid.

Las aportaciones señaladas satisfacen los criterios que la Agencia Nacional de Evaluación de la Calidad y Acreditación (ANECA) establece para el reconocimiento de tramos de investigación, en el área de conocimiento en el cual se realiza la tesis. La fecha de la aportación está comprendida en el período en el cual el alumno ha estado matriculado en los estudios de doctorado. Ambos requisitos son establecidos en el artículo 3 de la RESOLUCIÓN de 8 de junio de 2016, del Rectorado de la Universidad de Valladolid, por la que se ordena la publicación del Acuerdo del Consejo de Gobierno de 3 de junio de 2016, por el que se aprueba la normativa para la presentación y defensa de la tesis doctoral en la Universidad de Valladolid.

\section{Capítulo 2. Revisión de la tecnología del micro-riego para el establecimiento de brinzales}

\section{*Capítulo en Libro}

Martínez de Azagra A, Del Río J (2017) Capítulo 12. Oasificación, recolección de agua y riego de brinzales. Martínez de Azagra A, Gómez A (eds) en Hacia un agua justa pp; 285-308. Ediciones Universidad de Valladolid, Valladolid

\section{*Artículo en publicación indexada}

Martínez de Azagra A, Del Río J (2014) World map of potential areas for the use of water cooling pitchers (botijos), Journal of Maps, 11 2:240-244. doi:10.1080/17445647.2014.935499

\section{Artículo en congreso}

Martínez de Azagra A, Del Río J (2015) Microrriego de brinzales a través de recipientes porosos enterrados: Fundamentos teóricos y prácticos. Cuadernos de la Sociedad Española de las Ciencias Forestales 41:47-58

Artículo en revista de divulgación

Martínez de Azagra A, Del Río J (2012) Los riegos de apoyo y de socorro en repoblaciones forestales. Foresta 53:32-4

Artículo pendiente de revisión

Pitcher irrigation: some theoretical and Practical aspects enviado a: Irrigation and Drainage 


\section{Capítulo 4. Evaluación comparativa de la eficiencia técnica de los sistemas de riego de brinzales}

Artículo en congreso

Del Río J, Reque JA, Martínez de Azagra A (2018) Evaluación comparativa de la eficiencia técnica de los sistemas de riego de brinzales. IV Reunión del grupo de trabajo de hidrología forestal. Sociedad Española de las Ciencias Forestales, 26-27 de junio de 2018, Palencia

Capítulo 5. To replant or to irrigate: A silvicultural decision model for afforestation projects

\section{*Artículo en publicación indexada}

Del Río J, Reque JA, Martínez de Azagra A (2018) To replant or to irrigate: A silvicultural decision model for afforestation projects. Forest Policy and Economics 93:18-29. doi: 10.1016/j.forpol.2018.05.007

\section{Artículo en congreso}

Del Río J, Gómez E, Reque JA, Martínez de Azagra A (2013) Reponer marras o regar brinzales: una disyuntiva a analizar en zona árida. Martínez C, Lario F, Fernández B (eds). Avances en la restauración de sistemas forestales. Técnicas de implantación. Sociedad Española de las Ciencias Forestales-Asociación Española de Ecología Terrestre (2013), pp 13-18

Del Río J, Reque JA, Martínez de Azagra A (2016) Viabilidad económica de los microrriegos en repoblaciones. Cuadernos de la Sociedad Española de las Ciencias Forestales 42:75-90

\section{Capítulo 6. Herramienta para la integración económica del riego de brinzales en el diseño de plantaciones forestales}

\section{*Patente o propiedad intelectual}

El software descrito en este capítulo es un producto de propiedad intelectual registrado y adquirido por la Universidad de Valladolid a los autores, mediante el programa de transferencia Prometeo 2016 con la siguiente calificación:

«Teniendo en cuenta la información que se obtiene del anterior análisis y contabilizando las distintas puntuaciones asignadas en los diferentes parámetros tenidos en cuenta, se llega a la valoración del presente resultado de investigación con un índice de 3,3. La invención presenta una novedad respecto al estado de la técnica actual, por lo que se estima su registro como válido y muy oportuno. Con estas premisas se entiende por tanto que, dado el nivel tecnológico de la invención, y su singularidad, se hace necesario de la manera más inminente posible su protección frente a las empresas del sector y desarrolladores en el ámbito de la $I+D+i$ relacionado con las aplicaciones». 
Disponible en http://wally.gti.tel.uva.es/CytUVA/proyecto.php?id=346. La documentación de compraventa del software está depositada en la Oficina de Transferencia de Resultados de Investigación (OTRI) de la Universidad de Valladolid

Capítulo 7. Estimación del tamaño potencial del mercado de sistemas de riego de brinzales en plantaciones forestales en tierras áridas

Artículo en congreso

Del Río J, Reque JA, Martínez De Azagra A (2018) Estimación del tamaño potencial del mercado de sistemas de riego de brinzales en plantaciones forestales en tierras áridas. IV Reunión del grupo de trabajo de hidrología forestal. Sociedad Española de las Ciencias Forestales, 26-27 de junio de 2018, Palencia 
